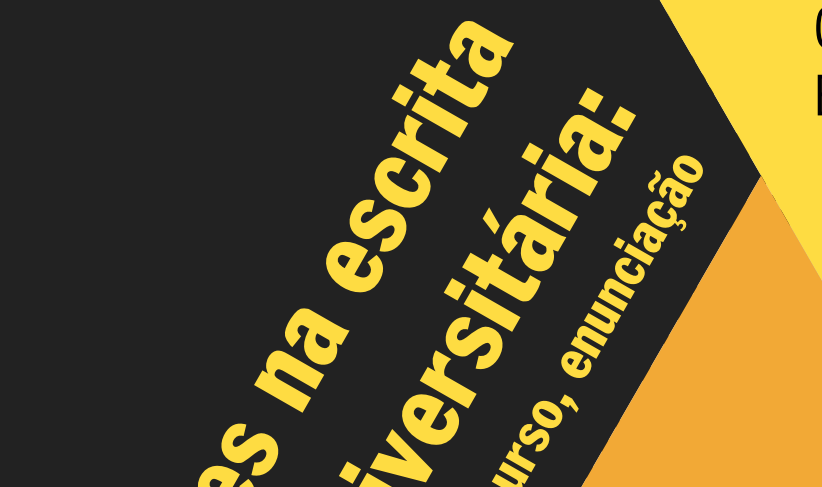

Cármen Agustini

TF

Ernesto Bertoldo

Organizadores $\left.\int_{G}^{B}\right|_{0} ^{W}$

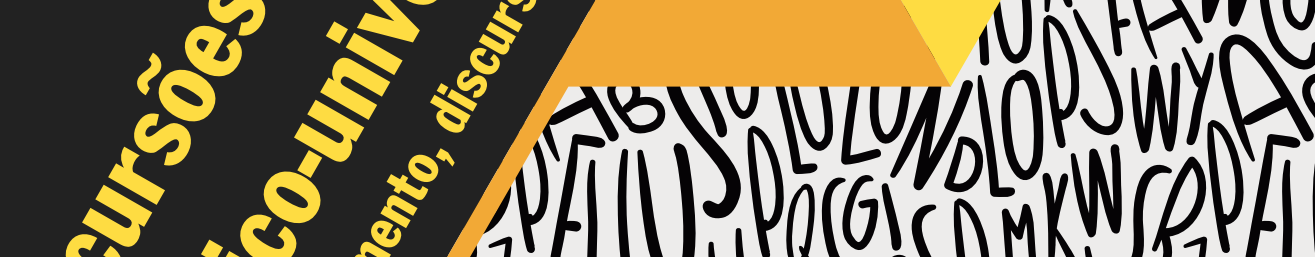

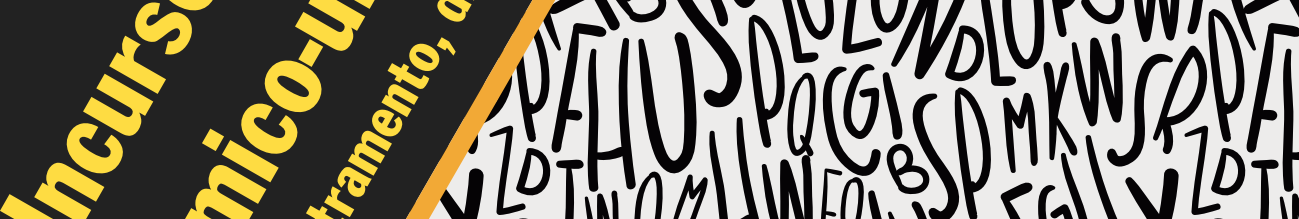

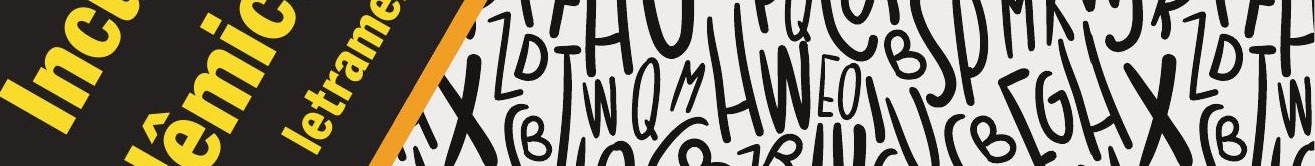
$\therefore$ (O)

0

$S E x=D$

DVME OY 7 y y u

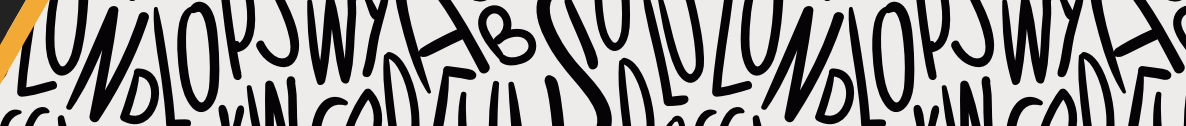
(G) AWE Bjo

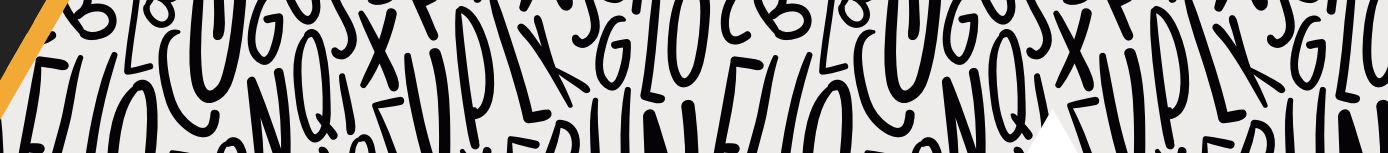
H. TDV $x$ E

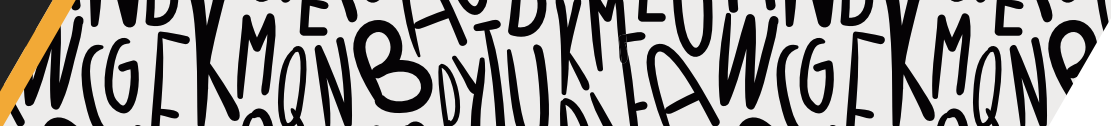

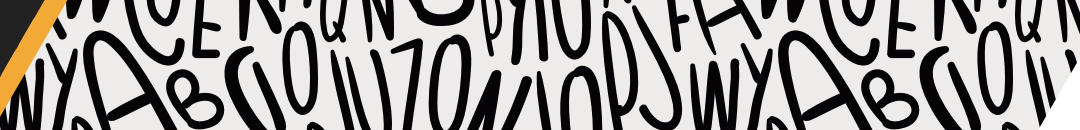

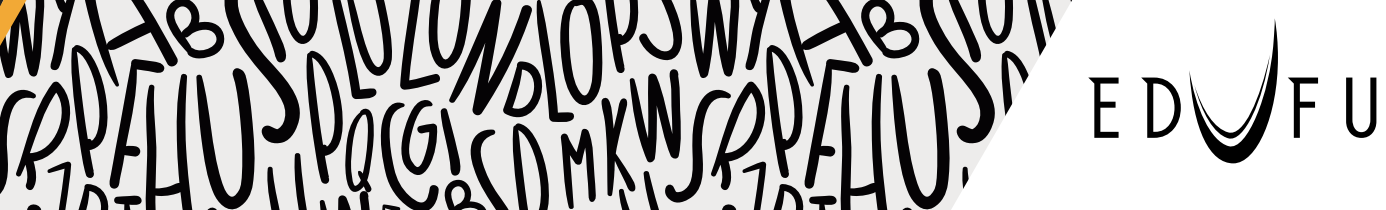

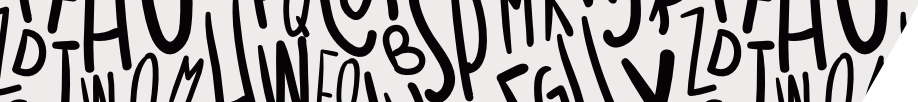

EUFU $1 / 1 / 6$

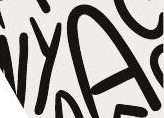
10 


\title{
Incursões na escrita acadêmico-universitária letramento, discurso, enunciação
}

\author{
Cármen Agustini \\ Ernesto Bertoldo \\ (orgs.)
}

\section{SciELO Books / SciELO Livros / SciELO Libros}

AGUSTINI, C., and ERNESTO, B., eds. Incursões na escrita acadêmico-universitária: letramento, discurso, enunciação [online]. Uberlândia: EDUFU, 2017, 239 p. ISBN: 978-65-86084-26-9. https://doi.org/10.7476/9786586084269.

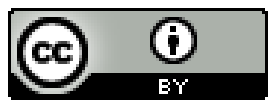

All the contents of this work, except where otherwise noted, is licensed under a Creative Commons Attribution 4.0 International license.

Todo o conteúdo deste trabalho, exceto quando houver ressalva, é publicado sob a licença Creative Commons Atribição 4.0. 
Incursões na escrita acadêmico-universitária: letramento, discurso, enunciação 


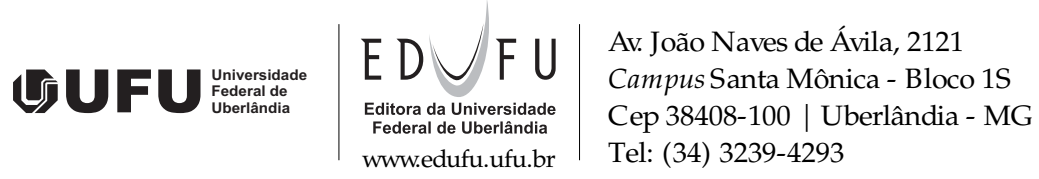

$\begin{aligned} \text { REITOR } & \text { CONSELHO EdTORIAL } \\ \text { Valder Steffen Jr. } & \text { Carlos Eugênio Pereira } \\ & \text { Décio Gatti Júnior } \\ \text { ViCE-REITOR } & \text { Emerson Luiz Gelamo } \\ \text { Orlando César Mantese } & \text { Fábio Figueiredo Camargo } \\ & \text { Hamilton Kikuti } \\ \text { DiRETOR DA EdUFU } & \text { Marcos Seizo Kishi } \\ \text { Guilherme Fromm } & \text { Narciso Laranjeira Telles da Silva } \\ & \text { Reginaldo dos Santos Pedroso } \\ & \text { Sônia Maria dos Santos }\end{aligned}$

Equipe de Realização

$\begin{aligned} \text { Editora de publicações } & \text { Maria Amália Rocha } \\ \text { Assistente editorial } & \text { Leonardo Marcondes Alves } \\ \text { Revisão } & \text { Cláudia de Fátima Costa } \\ \text { Revisão ABNT } & \text { Organizadores } \\ \text { Projeto gráfico, editoração e capa } & \text { Ivan da Silva Lima }\end{aligned}$


Cármen Agustini

Ernesto Bertoldo

Organizadores

Incursões na escrita acadêmico-universitária:

letramento, discurso, enunciação 


\section{Copyright 2017 (C) Edufu}

Editora da Universidade Federal de Uberlândia/MG

Todos os direitos reservados. É proibida a reprodução parcial ou total por qualquer meio sem permissão da editora.

I37n Incursões na escrita acadêmico-universitária : letramento, discurso, enunciação / Cármen Agustini, Ernesto Bertoldo, organizadores. Uberlândia : EDUFU, 2017.

239 p. : il.

Inclui bibliografia.

ISBN: 978-85-7078-463-6

1. Linguística. 2. Letramento. 3. Enunciação (Linguística) I. Agustini, Cármen Lúcia Hernandes. II. Bertoldo, Ernesto Sérgio, 1964-. III. Universidade Federal de Uberlândia. IV. Título.

CDU: 801 


\section{Sumário}

7 A escrit(ur)a acadêmica e o processo de assunção ao discurso acadêmico

21 Letramentos acadêmicos: avanços e críticas recentes

Brian Street

35 Promoção, operacionalização e funcionalidade do texto acadêmico

Sulemi Fabiano-Campo

José Antônio Vieira

55 A escrita acadêmica em provas. A descontinuidade na mobilização teórica Cármen L. H. Agustini

Mariana da Silva Marinho

73 O laço na escrita em textos acadêmicos: um estudo enunciativo Jorama de Quadros Stein

Marlene Teixeira

93 A escrita na universidade: uma reflexão a partir do que os alunos dizem em seus textos

Luciene Juliano Simões

Maristela Juchum

107 professor no processo de constituição do aluno pela escrita acadêmica Ernesto S. Bertoldo

121 Escrit(ur)a acadêmica: inscrição de si no discurso universitário-científico Marluza T. da Rosa

141 Os mistérios que envolvem a escrita acadêmica Elizabeth Maria da Silva

153 Autoria em redações do Enem e enunciação escrita: uma possível conjugação a partir da perspectiva de Benveniste Míriam Silveira Parreira

173 A escrita do relatório: aprendizagem e profissionalização em cursos técnicos de nível médio

Léa Dutra Costa

193 Letramento acadêmico no curso de Letras - Português Maria de Lourdes Guimarães de Carvalho

221 Escrevendo na e para academia: um estudo sobre a incorporação do discurso acadêmico no gênero relato de experiência

Roberta Andrade Meneses

Williany Miranda da Silva 


\section{A escrit(ur)a acadêmica e o processo de assunção ao discurso acadêmico}

A possibilidade de consolidarmos nossas pesquisas depende, indubitavelmente, dentre outros fatores, do suporte que recebemos de grupos de pesquisa que se organizam em torno de temas de interesse. Este é o caso desta coletânea. Sua realização foi possível porque seus organizadores tiveram o suporte teórico-metodológico e, também, logístico do Grupo de Pesquisa e Estudos em Linguagem e Subjetividade (GELS).

O GELS, formado em 2005, mantém um conjunto de atividades voltadas para a formação, interlocução e apresentação de pesquisas dos membros, a fim de (re)pensar os modos de (re)formulá-las e de desenvolvê-las, assim como para a consolidação dos trabalhos de pesquisa dos membros do grupo, sempre em torno de temas que levam em conta a relação entre linguagem e subjetividade.

Nesse seu propósito de interlocução, o GELS, nos últimos quatro anos, vem contando com o suporte do projeto Procad/Casadinho que se caracteriza pelo intercâmbio de pesquisa, muito produtivo, entre programas de pós-graduação consolidados e em consolidação, com o apoio financeiro das agências de fomento brasileiras: CAPES e CNPq.

Diante do exposto, esta coletânea ilustra a preocupação que o GELS assume com questões afeitas ao ensino e à aprendizagem de escrita e de leitura, neste caso específico, no espaço acadêmico-universitário, sob a óptica da relação entre linguagem e subjetividade. Nesse sentido, o GELS procura sempre divulgar seus resultados de pesquisa, compartilhando- 
os com outros pesquisadores que não fazem, necessariamente, parte do grupo. Um caso específico, que resultou na produção desta coletânea, o GELS propôs um grupo de trabalho no IV SIELP - Simpósio Internacional de Ensino de Língua Portuguesa- cujo objetivo foi o de problematizar a escrita acadêmica na assunção dos alunos à ordem do discurso acadêmicouniversitário, conforme elucidamos neste capítulo.

Parece consensual que a constituição de um aluno universitário no e pelo discurso acadêmico encerra um processo complexo que comporta uma demanda para a sua entrada em uma ordem discursiva (Foucault, 1971) outra. Essa outra ordem discursiva exige, por sua vez, o exercício de práticas discursivas acadêmicas que, em última instância, só podem passar a fazer parte do repertório do universitário, caso ele consiga enfrentar a diferença de outros modos de dizer possíveis a partir da entrada nessa outra ordem discursiva: a do discurso acadêmico.

Nesse processo de entrada na ordem do discurso acadêmico-universitário, a escrit(ur)a é um dos desafios que o aluno universitário enfrenta, uma vez que se trata de um processo que faz, necessariamente, com que ele se confronte com a diferença entre os seus modos de dizer e aqueles próprios ao discurso acadêmico-universitário. Não temos nesse processo a garantia de que a constituição do aluno universitário pelos modos de dizer do discurso acadêmico-universitário ocorrerá, já que não são todos os que suportam a angústia provocada pela diferença e, em decorrência, pelas coerções oriundas do discurso acadêmico-universitário e de suas especificidades.

Não é possível no espaço discursivo acadêmico-universitário dizer qualquer coisa de qualquer modo. Dito de outra maneira: esse confronto, tal como postulamos aqui, provoca, ainda, uma outra relação com o saber e (com) a sua produção. É notório que o conhecimento produzido nos círculos acadêmico-universitários se caracteriza, basicamente, por se afastar, radicalmente, daquele produzido no espaço do senso comum, mesmo quando dele o aluno universitário faz o seu ponto de partida.

A tarefa, então, que se apresenta a um aluno universitário, em seu processo de entrada nessa outra ordem discursiva que lhe (im)põe outros modos de dizer, comporta uma via de mão dupla: por um lado, para que ele se constitua nesses novos modos de dizer, ele, necessariamente, precisa se submeter às leis que compõem as regras de construção discursiva de tais modos; por outro lado, precisa encontrar uma maneira de subverter essas regras de tal forma que a elas não sucumba. 
Isso porque constitui nosso entendimento a entrada na ordem do discurso acadêmico-universitário e, em decorrência, a constituição de um aluno universitário pela via da escrita acadêmica deve contemplar uma escrita institucionalizada e, ao mesmo tempo, subjetiva, de modo a se afastar da mera reprodução; por vezes, teóricas que se encarrega, sobretudo, de referendar, no espaço acadêmico-universitário, autores que, supostamente, seriam os portadores das verdades científicas e que, por essa razão, deveriam ser reproduzidos-perpetuados.

Ao contrário disso, uma escrita acadêmica institucionalizada e subjetiva, assim entendida em seu jogo tensivo constitutivo, pode levar, em decorrência, a uma responsabilidade enunciativa. Tal responsabilidade supõe a tomada da palavra a partir das exigências que a assunção à ordem do discurso acadêmico-universitário demanda do(aluno) universitário.

Para explicitar e problematizar questões que envolvem o que postulamos aqui, essa coletânea propõe discutir produções escritas de (alunos) universitários às voltas com o processo de apropriação da escrit(ur)a acadêmica, momento em que os alunos enfrentam concretamente a escrita a partir das exigências de práticas discursivas específicas.

A possibilidade de uma escrita acadêmica institucionalizada e subjetiva, que proporcione uma responsabilidade enunciativa no espaço acadêmico-universitário, e, para além dele, parece estar justamente na tensão entre a possibilidade de assumir esses outros modos de dizer que são específicos ao discurso acadêmico-universitário, dadas as condições de entrada em um discurso outro, e a impossibilidade que se (im)põe de se dizer nessa outra ordem discursiva, dadas as condições que assim possam, igualmente, determinar. Trata-se, portanto, de uma zona de entremeio a qual o aluno universitário deve atravessar para adentrar os pórticos da escrit(ur)a acadêmica e, assim acontecendo, instaurar-se nele o processo de assunção ao discurso acadêmico.

Essa questão desafiadora é tratada a partir de diferentes abordagens e perspectivas, de modo que a escrit(ur)a e a leitura acadêmica tornam-se também objetos de estudo e, em decorrência, de pesquisa. Nesse caso específico, em relação à entrada do aluno-universitário nesses modos de dizer específicos que encontram na leitura e na escrit(ur)a acadêmica seu suporte.

Sucintamente, podemos dizer que os estudos sobre letramento abrangem desde aqueles que tratam a leitura e a escrita sob o ponto de vista meramente cognitivo, até aqueles que abordam a questão como um 
fenômeno que deve ser considerado sob a óptica social, reconhecendo que são nas práticas sociais, políticas, econômicas e culturais que tanto a leitura quanto a escrita devem ser consideradas, o que Gee (2000) chama de "virada social". Essa virada social, tal como apregoada pelo autor, possibilitou, assim, o rompimento com o paradigma cognitivo, abrindo a possibilidade para outros estudos que, notadamente, partissem de uma abordagem do fenômeno da escrita e da leitura a partir do ponto de vista social.

Decorrente dessa abordagem social do letramento, atualmente, vemos, com frequência, estudiosos que se reportam aos novos estudos sobre o letramento, assim como aos estudos que abordam a questão, referindo-se aos multiletramentos. Trata-se de perspectivas que, se por um lado não são antagônicas, por outro não se equivalem. No primeiro caso, de acordo com Bevilaqua (2013, p.3)

[a] denominação Novos Estudos do Letramento foi cunhada por Gee (1991 apud Street, 2003) quando da observação que emergiam, no final dos anos 1970 e início dos anos 1980, na América do Sul (Brasil), América no Norte (Estados Unidos) e Europa (Reino Unido), estudos que focavam muito mais o lado social do letramento do que seu lado cognitivo (Street, 2003, p.77). Logo, o atributo 'novo' está relacionado à 'virada social'.

Já, no segundo caso, a referida autora (2013, p.4) esclarece que

[alguns] anos após o surgimento dos NLS, mais especificamente em 1994, na cidade estadunidense de Nova Londres, New Hampshire, renomados teóricos, sobretudo da Linguística e Educação, oriundos de três países - Estados Unidos, Grã-Bretanha e Austrália - reuniramse a fim de debater os sérios problemas pelos quais o sistema de ensino anglo-saxão estava passando (Cope; Kalantzis, 2000). Esse grupo de teóricos tornou-se mundialmente famoso pela autodenominação de New London Group, ou Grupo de Nova Londres. Deste encontro, resultou um documento denominado de "manifesto programático" (Cope; Kalantziz, 2000, p.164), construído a dez mãos e cujos motes principais foram: a crescente diversidade linguística e cultural presente nesses países (fruto de uma economia globalizada) e a multiplicidade de canais e meios (modos semióticos) de comunicação (resultado das novas tecnologias). Esses dois motes foram responsáveis pelo prefixo multi, da denominação Multiletramentos (Cope; Kalantzis, 2000, 2009). 
Como podemosnotar,não há realmentepontos de discordânciaentre as duas denominações novos estudos sobre letramento e multiletramentos. Tratar-se, muito mais, a nosso ver, de uma questão que diz respeito às possibilidades de alcance que a noção de multiletramentos possibilitaria, no sentido de responder às demandas da contemporaneidade que cada vez mais exigem diferentes tipos de habilidades /competências frente a um avanço galopante das novas tecnologias, resultantes da produção de conhecimento nas sociedades contemporâneas globalizadas, gerenciadas pelo capitalismo. Apesar de reconhecermos o lugar e a pertinência da noção de multiletramentos, o prefixo multi, ao pluralizar a noção de letramento poderia incorrer no risco de esvaziar esse conceito, uma vez que produz um efeito de indistinção sobre o que seria ler e escrever em diferentes espaços discursivos.

Ademais, parece-nos, ainda que o conceito, assim, ficaria muito mais associado a levar, simplesmente, alguém (os alunos universitários, por exemplo) ao "domínio" de diferentes habilidades ou competências, necessárias à sobrevivência no mundo globalizado, apagando-se, potencialmente, seu caráter de subversão às regras coercitivas e homogeneizantes desse mesmo mundo contemporâneo, globalizado.

Essa coletânea está em consonância com estes trabalhos em relação à questão desafiadora; no entanto, cada um, segundo sua filiação teórica, busca respondê-la a seu modo, de tal forma que essa coletânea não se constitui somente de perspectivas homogêneas ou afins; ela apresenta um conjunto de trabalhos que é, com efeito, heterogêneo; sem, contudo, perder de vista a questão desafiadora sobre os modos de entrada na ordem discursiva acadêmico-universitária como estamos argumentando aqui. Assim, a ideia da coletânea atinge, diretamente, essa questão, por vezes conturbada, da passagem da Educação Básica para a Educação Acadêmico-Universitária.

O texto de Brian Street, Letramento acadêmico: avanços e críticas recentes, que abre a coletânea, constitui uma reflexão relevante para a discussão da questão desafiadora da passagem da Educação Básica à Educação Acadêmico-Universitária. 0 texto apresenta, de forma problematizada, os diversos estudos, produzidos e em produção, sobre o letramento, de forma geral, e, em particular, sobre o letramento acadêmico, empreendidos na Europa, nos Estados Unidos e no Brasil. Reforça, ainda mais, a relevância mencionada o fato de que o autor mantém, juntamente com 
seu grupo de pesquisa, interlocução com pesquisadores brasileiros sobre o tema em questão. Esse fato contribui para a formação de novos pesquisadores brasileiros envolvidos com as questões teórico-metodológicas afeitas aos estudos sobre letramento.

O texto de Sulemi Fabiano-Campos e José Antônio Vieira, Promoção, operacionalização e funcionalidade do texto acadêmico, analisa os sentidos produzidos por meio das formas de marcação de outros discursos na escrita de monografias. Norteia a investigação empreendida pelos autores a seguinte pergunta:"quais os efeitos de sentido produzidos a partir do modo de utilização da voz do outro na escrita de textos acadêmicos?" Para trabalhar essa questão, os autores filiam-se às teorizações de Authier-Revuz sobre a heterogeneidade enunciativa, a fim de identificar as marcações do outro na escrita, e o valor de troca e o valor de uso (Rossi-Landi, 1985).

Com as análises da presença de marcações do outro na escrita de monografias, os autores verificaram as diferenças de uso e da funcionalidade social de uma teoria. Perceberam, ainda, que uma escrita desenvolvida na repetição e reprodução do que já foi dito pode desenvolver a ideia de que o texto produzido possui a função de promover um autor ou um conceito teórico utilizado como fundamentação. Verificaram, também, indícios de que a promoção do outro pode garantir a inserção e aceitação do trabalho acadêmico em uma comunidade científica, independente do desenvolvimento de uma análise que mobilize uma teoria.

Já o texto de Cármen Agustini e Mariana da Silva Marinho, A escrita acadêmica em provas. A descontinuidade na mobilização teórica, discute e analisa em que medida a inscrição do aluno universitário em uma teoria pode ou não afetar sua escrita na (re)produção de respostas às questões discursivas de provas, nas quais tenha que, a partir de uma teoria estudada em aula, analisar ou posicionar-se em relação a algum fato ou conceito linguístico. Com base nas teorizações de Émile Benveniste (1966, 1974 e 2012), as autoras propõem aferir a descontinuidade da relação entre locutor-scriptor, apropriação da língua escrita e manejo da teoria no espaço acadêmico-universitário.

Tomar a relação entre locutor-scriptor, apropriação da língua escrita e manejo da teoria como uma relação marcada pela descontinuidade, levou as autoras a promoverem uma diferenciação entre os comportamentos, de um lado, de ouvir e de escutar,em paralelo, por outro lado, com 
os comportamentos de falar e de dizer. Para tanto, analisaram recortes de provas feitas por (alunos) universitários de uma instituição pública de ensino superior e verificaram que a escrita desses (alunos) universitários descortinam uma relação (in)tensa e descontínua no manejo da teoria e, em decorrência, com a escrita acadêmica em provas, de tal modo que de uma questão discursiva para outra possa haver uma decalagem que transpõe a escrita acadêmica ao senso comum.

O texto de Jorama de Quadros Stein e Marlene Teixeira, o laço na escrita em textos acadêmicos: um estudo enunciativo, investiga o laço no processo de escrita entre professor-revisor e aluno-scriptor, a fim de promover uma ressignificação do ensino de escrita espaço acadêmicouniversitário. As autoras, filiadas às teorizações de Émile Benveniste (1966, 1974 e 2012), compreendem que a escrita é outro sistema semiótico, que pressupõe uma série de abstrações e que a reescritanão é uma reedição, mas uma nova enunciação, em que o locutor se institui como sujeito na e pela linguagem, e reproduz (Benveniste, 1966) uma certa relação com o mundo, renovando seu modo de estar na língua.

Para melhor expor a investigação, as autoras analisam um texto a partir das modificações realizadas pelo aluno universitário em função da interferência do professor. Para isso, mobilizaram as categorias da crítica genética, mostrando que, ao atentar para o processo de escrita, o professor coloca-se como interlocutor atento, numa relação de reversibilidade com o aluno, concedendo-lhe um novo lugar de enunciação, permitindo-lhe apropriar-se do texto como espaço de reinvenção possível. Esse espaço de reinvenção deve fornecer condições e repertório ao aluno universitário para que ele possa fazer sua passagem e, assim, ascender a uma escrita institucionalizada e subjetiva.

O texto de Luciene Juliano Simões e Maristela Juchum, A escrita na universidade: uma reflexão a partir do que os alunos dizem em seus textos, objetiva observar e analisar o que alunos universitários revelam em seus textos sobre suas escritas antes do ingresso no espaço acadêmicouniversitário e sobre o que é esperado deles nele. Ao analisar os textos de 45 alunos da disciplina Leitura e Produção de Texto I, matriculados em um Centro Universitário, as autoras perceberam, nas escritas, remissões a reflexões feitas sobre a própria escrita, destacando-se reflexões sobre dois momentos: a escrita antes de entrar na universidade que, segundo os alunos, representava um jeito de escrever e o ideal de escrita a ser 
atingido após o ingresso no espaço acadêmico-universitário que, para muitos, significa aprender a escrever de outro jeito.

Esses dois momentos colocam em evidência, à luz do letramento acadêmico, os conflitos existentes entre a escrita que produziam e a que é esperada pela universidade. Esse aspecto mostra-se recorrente nos textos dos alunos, o que aponta para a necessidade de o professor levar em conta, no seu planejamento, o letramento que os alunos já possuem antes de ingressarem no espaço acadêmico-universitário, a fim de romper com o discurso do déficit.

0 texto de Ernesto $S$. Bertoldo, O professor no processo de constituição do aluno pela escrita acadêmica, apresenta alguns aspectos do percurso de uma aluna em seu processo de entrada nas especificidades da escrita acadêmico-universitária. Contextualizado em um Curso de Letras que forma professores de língua portuguesa e de língua estrangeira, o capítulo relata a trajetória de uma aluna, enfocando sua relação com o professor formador, responsável pela disciplina Práticas Discursivas da Academia.

0 autor postula que um dos aspectos que caracteriza a relação do professor de escrita acadêmica com o professor em formação seria o de se levar em conta que o processo de constituição do aluno em formação em práticas discursivas acadêmicas letradas comporta uma tensão entre as duas partes, o que seria a condição para que esse professor em formação nelas se constituísse. Assim, os impasses e/ou as dificuldades, vivenciadas por uma aluna em formação, ao se confrontar com uma tarefa específica da escrita de uma resenha em língua estrangeira, são evidenciados no capítulo.

O texto de Marluza T. da Rosa, Escrit(ur)a acadêmica: inscrição de si no discurso universitário-científico, aborda a problemática da escrit(ur)a acadêmica pelo viés do falar de si, ruído advindo dos bastidores do discurso científico, que resta geralmente encoberto pela sua voz supostamente objetiva, mas no qual um sujeito faz sinal, apontando para o que há de real nesse discurso.

Respaldado no (du)elo conceitual que caracteriza a abordagem discursivo-desconstrutivista, a autora analisa excertos de entrevistas semidiretivas gravadas e transcritas, nos quais os participantes, (alunos) universitários em doutoramento, abordam não só sua relação com a escrita demandada institucionalmente, mas também sua própria inscrição, sua escritura, no discurso acadêmico-universitário. 
O texto de Elizabeth Maria da Silva, Os mistérios que envolvem a escrita acadêmica, problematiza, por sua vez, a escrita em espaço acadêmico-universitário a partir dos trabalhos de Lea e Street (1998); Lillis (2003), Zavala (2009); Street (2010), que identificaram reflexões feitas por alunos universitários sobre sua escrita acadêmica. Esses autores constataram que há dimensões "escondidas" subjacentes à avaliação da produção de textos acadêmico-universitários. 0 professor exigiria a escrita acadêmico-universitária sem explicitar certos critérios que acabariam sendo considerados no momento da correção, supondo, assim, que o aluno universitário já saiba o que é esperado de sua escrita.

Como o aluno universitário nem sempre detém tal saber, evidencia-se uma relação conflituosa entre as expectativas do docente e as interpretações do aluno. Nesse contexto, a autora entende que, para que a tensão entre professor e aluno seja, ao menos amenizada, cabe àquele explicitar para este os critérios que norteariam a avaliação de seus textos. A autora também considera necessário que seja criado um espaço para o aluno refletir sobre seu texto, tendo a oportunidade de compartilhar com o professor seus limites e potencialidades em relação à escrita acadêmico-universitária.

0 texto de Míriam Silveira Parreira, Autoria em redações do ENEM e enunciação escrita: uma possível conjugação a partir da perspectiva de Benveniste, analisa a escrita autoral da redação, tendo em vista que autor é aquele que aproveita a oportunidade para, em condição figurativa da enunciação escrita, expressar sua opinião, atuando como sujeito do discurso. Para tanto, analisa, a partir das teorizações de Émile Benveniste (1989, 1995, 2014), que, se o texto segue todas as regras de avaliação, produz-se a impressão de que o candidato se constituiria autor do texto.

Nesse sentido, a autora assume que a condição figurativa da enunciação escrita funciona comoíndice de assunção da intersubjetividade. Dessa forma, mobilizando os conceitos de Benveniste, em especial o conceito de intersubjetividade, o texto propõe que enunciação e autoria possam conviver e ser conjugadas em uma teoria do discurso. 0 texto de Léa Dutra Costa, A escrita do relatório: aprendizagem e profissionalização em cursos técnicos de nível médio, discute a demanda por relatórios produzidos por alunos do $1^{\mathfrak{0}}$ ano de uma escola pública mineira, após a realização de experimentos em laboratório de Ciências da Natureza e suas Tecnologias. A autora parte do pressuposto de que essa demanda é semelhante àquela que ocorre em cursos de graduação, em que habitualmente o aluno deve 
produzir um número elevado desses textos e ser capaz de relacionar teoria e prática através da sua escrita. Em conformidade com propostas teóricas e metodológicas interacionistas sócio-discursivas, os dados coletados de relatórios e entrevistas foram analisados levando-se em consideração o momento de vida do aluno e a sua competência discursiva.

Nesse sentido, o estudo atesta que relatórios são também largamente empregados na formação de profissionais de nível médio sob a premissa de que, ao escrevê-los, os alunos não só aprendem como são também preparados para o exercício de uma função no mercado de trabalho. Assim, baseando-se em conceituações bakhtinianas, o texto mostra, ainda, que a natureza dos relatórios caracteriza-se como formas prescritivas, altamente estáveis e portadoras de temas, estruturas e estilos próprios e convencionais. Ao contrário dos gêneros literários, os relatórios são pouco afeitos à expressão de individualidade e identidade, o que problematiza seu uso no ensino médio, especialmente, no contexto de aprendizagem de ciências em cursos técnicos.

0 texto de Maria de Lourdes Guimarães de Carvalho, Letramento acadêmico no curso de Letras-Português, problematiza as dificuldades das práticas de leitura e escrita de textos acadêmicos de alunos de cursos de licenciatura, enfatizando que o gerenciamento das vozes do discurso mostra-se como um ponto crítico dessas produções. Propõe, assim, responder quais são as marcas linguístico-textuais e discursivas que indiciam o letramento acadêmico. 0 texto centra-se no gênero resenha, escrita por professores em formação, já que é considerada como um gênero recorrente no espaço acadêmico-universitário e deve ser compreendido como auxiliar no desenvolvimento das capacidades de síntese, interpretação e crítica, levando o estudante a pesquisar, ler e elaborar textos científicos mais complexos.

0 ponto alto dessa investigação é contribuir para o redimensionamento dos princípios teóricos e procedimentos metodológicos que orientam e definem as atividades de ensino/aprendizagem da leitura e da escrita acadêmica na licenciatura em Letras. Ademais, os resultados da investigação oferecem indícios sobre possíveis alternativas para se enfrentar a questão do letramento acadêmico nos demais cursos de graduação.

O texto de Roberta Andrade Meneses e Williany Miranda da Silva, Escrevendo na e para academia: um estudo sobre a incorporação do discurso acadêmico no gênero relato de experiência, coaduna-se à proposta 
de análise de gêneros em espaço acadêmico-universitário, partilhando da ideia de que o gênero é uma forma de agir retoricamente para alcançar determinados fins, refletindo a esfera de atividade humana da qual se origina (Swales, 1990). Assim sendo, contribui no sentido de depreender que conhecimentos e estratégias o aluno universitário, inserido na produção de escrita acadêmico-universitária, mobiliza para integrar-se à comunidade discursiva acadêmica.

Para tanto, analisa introduções do gênero relato de experiência de dois alunos universitários de um curso de Letras, nas quais foram identificadas as diferentes estratégias utilizadas por eles na produção da escrita acadêmico-universitária, a partir das teorizações advindas da corrente sociorretórica (Miller, 1984; Swales, 1990; Bazerman, 2006), no que tange à análise de gêneros; Coracini (1991), no que se refere ao discurso da ciência; bem como Silva (2002), no que concerne à delimitação do gênero relato de experiência.

Como vimos argumentando, os trabalhos aqui elencados possibilitam, sob diversos pontos de vista, um voo panorâmico sobre a questão desafiadora da passagem da Educação Básica à Educação Acadêmico-Universitária no que tange ao ensino de escrita. Constitui nosso desejo, na condição de professores-pesquisadores engajados com essa questão, que nossos leitores possam, assim, usufruir das reflexões aqui apresentadas como suporte para o enfrentamento da complexidade dos problemas e das questões que envolvem a escrita acadêmico-universitária em sua prática. Boa leitura a todos!

\section{Referências}

BACHELARD, Gaston. A Formação do espírito científico: contribuição para uma psicanálise do conhecimento. Tradução de Estela dos Santos Abreu. Rio de Janeiro: Contraponto, 1996.

BAZERMAN, C. Gênero, agência e escrita. HOFFNAGEL, J. C; DIONISIO, A. P. (Org.).Tradução e adaptação Judith Chambliss Hoffnagel. São Paulo: Cortez, 2006.

BENVENISTE, E. Problemas de linguística geral I. Tradução de Maria da Glória Novak e Maria Luisa Neri: revisão do prof. Isaac Nicolau Salum. 5 ed. Campinas, SP: Pontes Editores, 2005. Tradução de: Problèmes de linguistique générale.

Problemas de linguística geral II. Tradução de Eduardo Guimarães et al. 2 ed. Campinas, SP: Pontes Editores, 2006. Tradução de: Problèmes de linguistique générale II. 
BENVENISTE, E. Últimas aulas no Collège de France (1968 e 1969). Tradução de Daniel Costa da Silva et al. São Paulo: Unesp, 2014. Tradução de: Dernières leçons: Collège de France (1969 e 1969).

BEVILAQUA, R. Novos estudos do letramento e multiletramentos: divergências e confluências.Revista Virtual de Letras, v.5, n.1, jan./jul, 2013.

CORACINI. M. J. R. F. Um fazer persuasivo: o discurso subjetivo da ciência. Campinas, SP: Pontes, 1991.

DELEUZE, Gilles. Diferença e repetição. Tradução brasileira de Luiz Orlandi e Roberto Machado. Rio de Janeiro: Graal, 1988.

FOUCAULT, M. A ordem do discurso. São Paulo: Edições Loyola, 1996.

GEE, J.P. The new literacy studies: from "socially situated" to the work of the social. In: BARTON, D; HAMILTON, M.; IVANIC, R. (Eds.). Situated Literacies: Reading and Writing in context. London: Routledge, 2000a, p.180-196.

KUHN, Thomas S. The structure of scientific revolutions. Chicago: The University of Chicago, 1962.

LEA,M.R; STREET,B.V.Student writing in higher education: anacademic literacies approach. Studies in Higher Education. v.23, p.157,June 1998.

LILLIS, T. Student writingas 'academic literacies': drawing on Bakhtin to move from critique to design. Language and Education, v.3, n.17, p.192-207, 1998.

MILLER, Carolyn R. Genres social action. Quarterly Journal of Speech, n.70, p.151$167,1984$.

PÊCHEUX, Michel. L'énoncé: enchássement, articulation et dé-liaison. Actes du Colloque Matérialités discursives. Université Paris X - Nanterre, 24-26 avril 1980. In: CONEIN, Bernard. et al. (orgs). Matérialités discursives. Lille: Presses Universitaires de Lille, 1981, p.143-148.

Discourse: structure or event? Actes du Colloque Marxism and Interpretation of Culture: Limits, Frontiers, Boundaries. L'Université Urbana-Champaign, 8-12 juillet 1983. In: PÊCHEUX, Michel. L'inquietude du Discours. Textes choisis et présentés par Denise Maldidier. Paris: Éditions des Cendres, 1990, p.303-323.

ROSSI-LANDI, F. A linguagem como trabalho e como mercado: uma teoria da produção e da alienação linguísticas. Tradução de Aurora Fornoni Bernardini. São Paulo: Difel, 1985.

SILVA, J.R. Relato de experiência didática: elementos para a descrição e ensino do gênero. 90f. Dissertação de Mestrado (Mestrado em Linguística). Universidade Federal da Paraíba - UFPB. João Pessoa, Paraíba. 2002.

STREET, B. What's "new" in new literacy studies? Critical approaches to literacy in theory and practice 2003. Current Issues in Comparative Education, v.5, n.2, 2003. Disponível em: <http://www.tc.columbia.edu>. Acesso em 10 de maio de 2010.

SWALES, J. M. Genre analysis: English in academic and research settings. Cambridge: Cambridge University Press, 1990. 
ZAVALA,Virgínia.“Quién está diciendo eso?” Literacidad académica, identidad y poder en la educación superior. In: KALMAN; STREET (Coord.) .Lectura, escritura y matemáticas. México: Siglo XXI, p.348-363,2009.

Cármen Agustini

Ernesto Bertoldo 


\section{Letramentos acadêmicos: avanços e críticas recentes ${ }^{1}$}

Brian Street ${ }^{2}$

\section{Abordagem de letramento acadêmico}

O estudo etnográfico de práticas de letramento acadêmico relatadas por Lea e Street (1998) chamou consideravelmente a atenção para a área dos estudos sobre letramento e dos estudos no âmbito do ensino superior. Curiosamente, os artigos de 1998 ainda são citados como os mais frequentemente mencionados na revista Studies in Higher Education. Baseados numa pesquisa realizada com algumas universidades inglesas, Mary Lea e eu propusemos três modelos que deveriam ser sustentados pelos profissionais da universidade participante no que concerne à redação dos alunos: habilidades de estudo, socialização acadêmica e letramento acadêmico.

Particularmente, à época das pesquisas, predominava fortemente, tanto na teoria, quanto na prática, o modelo de "habilidades de estudo". Todavia, como esse artigo demonstrou, e conforme reforçado e desenvolvido por estudos posteriores, a realidade - na prática - é de que há exigências múltiplas para que o aluno escreva de acordo

\footnotetext{
${ }^{1}$ Tradução de Stéfano Paschoal

${ }^{2}$ Agradecemos a Mary Lea pela coautoria do artigo original intitulado "Academic Literacies 15 years on", com algumas de suas partes reproduzidas aqui.
} 


\section{Brian Street}

com o contexto, variando conforme a disciplina, mas, também, dentre outras coisas, conforme as pressões institucionais, incluindo questões de financiamento bem como o papel dos tutores da disciplina, e não apenas dos estudantes.

Descrevemos isso como o modelo de "socialização acadêmica", que buscou levar em conta algumas dessas questões ao "integrar socialmente" os alunos no tocante às exigências acadêmicas. Entretanto, passamos a discutir sobre a necessidade de ampliarmos nosso entendimento e nossa prática nesse âmbito e, então, descrevemos este terceiro modelo, intitulado "Letramento Acadêmico" (doravante LA).

O LA exige dos pesquisadores que investiguem e, dos que lidam com a prática, que considerem a variedade evidente de práticas de Letramento Acadêmico em contextos específicos, concebendo o letramento como Prática Social nos últimos anos (cf. Gee, J. P., 1990; Lankshear, C e Knobel, M 2003; Collin, R. e Street, B. (a ser publicado); Street, B. 2005; 2012).

A abordagem da prática social para a escrita acadêmica inclui, para aqueles que trabalham no contexto acadêmico, ajustar novos e variados gêneros de escrita, diferentes exigências em termos de argumentação, estruturação de informações e estilos retóricos, bem como diferentes preferências dos professores. Tal variação e complexidade significaram que os dois modelos que muito provavelmente dominariam esta área, - habilidades de estudo e socialização acadêmica - não obstante tendo nos proporcionado um ponto de partida útil (cf. Wingate, 2015), foram concebidos de forma muito limitada para abarcar a gama de necessidades, exigências e práticas acerca do exercício de escrita na universidade.

\section{Avanços e críticas recentes}

Publicações atuais desenvolveram e ampliaram as descobertas e teorizações originais no artigo de $1998^{3}$ (Blommaert et al., 2008). Além disso, há relações interessantes a serem estabelecidas com o trabalho em áreas similares em diferentes países, especialmente no Reino Unido e nos Estados Unidos e, mais recentemente, também na França. 0 trabalho recente no Brasil - com a expansão das universidades - também tem se desenvolvido e se referido a diversas questões levantadas em outros lugares. Transmitirei brevemente minha própria experiência com essas questões nos últimos anos.

${ }^{3} \mathrm{O}$ autor se refere, aqui, ao artigo escrito por ele e Lea em 1998. 
Nos Estados Unidos, termos como "Escrita no âmbito das disciplinas/dos currículos", bem como gênero (cf. Russell et al., 2009) têm sido dignos de nota. Tanto nos Estados Unidos quanto no Reino Unido, o conceito de Inglês para Fins Acadêmicos (ESP) tem sido o foco de muitos pesquisadores e professores interessados no papel da língua inglesa em ambientes acadêmicos (p. ex., Wingate e Tribble, 2012). Na França, o trabalho de retórica e gênero abrange a questão da escrita na universidade (cf. Castelló e Donahue, 2012), Delcambre, I. \& Reuter, Y. (2010) têm feito relações, na França, sobre didática, com os campos assinalados aqui; da mesma forma, Donahue, T. (2009) que relaciona "Gênero e trabalho disciplinar" em pesquisas sobre didática na França; e Delcambre, I. \& Donahue, C. (2011, autores que têm observado os letramentos acadêmicos de universitários franceses. No Reino Unido, têm havido algumas contestações a alguns dos conceitos iniciais desenvolvidos por mim e por Mary Lea. Neste artigo, indicarei brevemente alguns desses avanços e críticas recentes.

\section{Críticas no Reino Unido}

No Reino Unido, Lillis e Scott (2007) têm discutido que a adesão a uma abordagem de letramento acadêmico envolve reconhecer a necessidade de transformação - e não de mera reprodução - das formas padronizadas correntes de leitura e escrita. Em conformidade com nosso artigo de 1998, eu e Mary Lea não concordamos completamente com essa abordagem. Certamente, ao discutir o fato de que a abordagem LA (letramento acadêmico) exige uma mudança sobre como se conceitua o auxílio à escrita, afastando-se, por exemplo, do modelo "deficitário" e aproximando-se bem mais de práticas variadas de letramento associadas a diferentes disciplinas e contextos em educação, nós não necessariamente a veríamos como uma mudança que envolve um desafio político dessa natureza às instituições, como parecem sugerir Scott e Lillis.

Pode ser, por exemplo, que alunos e professores reconheçam os gêneros ou estilos específicos de letramento necessários em determinado nível e aprendam a trabalhar com isto, mais do que tentarem subjugálo - "reflexão crítica" mais do que a tentativa de "transformar" práticas correntes, nos termos de Scott e Lillis. 


\section{Brian Street}

Percebemos, por um lado, uma diferença sutil entre tornar visíveis aspectos de poder e de autoridade e como esses aspectos estão incorporados nas práticas de letramento e, por outro, a noção de transformação. Enquanto, seguramente, interessados em como a universidade poderia transformar tais práticas e, interessados, também, na importância, por exemplo, de se contestarem formas de gênero e formas hierárquicas de práticas de conhecimento e de se contestarem, ainda, os processos através dos quais os estudantes são excluídos, consideramos a abordagem LA, tanto do ponto de vista da pesquisa, quanto da prática, como algo talvez mais etnográfico e menos político, na medida em que auxilia os participantes a perceberem e conceitualizarem o que de fato ocorre mais claramente como uma base para suas próprias atividades.

Tal consciência, então estendida, poderia envolver uma participação mais consciente nas práticas de escrita acadêmica ou contestar as formas dominantes com que são interpretadas, dependendo do contexto e dos interesses dos participantes.

Como este campo de pesquisa ainda está em desenvolvimento, novas vertentes e orientações estão constantemente surgindo. Embora quiséssemos nos manter fieis ao sentido original - usado por nós - do termo "letramento acadêmico", tal qual se vê no artigo de 1998, Mary Lea e eu temos perfeita consciência de que aqueles que trabalham diretamente com os estudantes, especialmente, têm usado o termo com diferentes acepções. Coffin e Donohue (2012), por exemplo, no tocante ao enfoque de características textuais e ao ensino de "letramento acadêmico", e Wingate e Tribble (2012), contestaram o que consideram uma dicotomia aparente entre "transformacional" e "normativo", baseados principalmente em sua leitura de Scott e Lillis (2008). Esses autores discutiram sobre o "melhor de ambos os mundos". Eles também apresentaram uma explicação mais positiva da atividade principal, incluindo habilidades de estudo e de socialização acadêmica, como a importância do foco em habilidades linguísticas e características textuais às quais os alunos deveriam se dedicar.

Na tentativa de alcançar "o melhor de ambos os mundos", eles lançaram mão de três abordagens para o ensino da escrita e teorias subjacentes: Letramento acadêmico, Inglês para Fins Acadêmicos e Linguística Sistêmico-Funcional. Todas elas contribuíram com princípios úteis. Entretanto, eu ainda aproveitaria os princípios estabelecidos 
no artigo escrito com Mary Lea e agiria de forma crítica em relação a quaisquer perspectivas que sugiram que os professores se remetam ao modelo de "habilidades de estudo" sem qualquer crítica.

No tocante a tópicos sobre língua, por exemplo, a abordagem tradicional de Inglês para Fins Acadêmicos ainda - eu diria - enfatiza muito fortemente o nível de habilidades e, no caso da língua, as características formais e padronizadas do inglês. De fato, o trabalho recente sobre multilinguismo e diversidade reconhece haver várias "línguas inglesas", assim como a abordagem LA mostra que há diversos letramentos.

Leung $(2008,2010)$, por exemplo, estendeu os argumentos principais na abordagem do letramento acadêmico para criar relações entre os diferentes expedientes separados até agora no âmbito profissional e o ensino de língua inglesa e, durante o processo, (re)inseriu a "língua" nas discussões sobre o letramento. Leung e Street (2012), com base num projeto financiado pelo Economic and Social Research Council (ESRC), estenderam esta abordagem à educação de nível escolar e investigaram de forma mais extensa a língua e as práticas de letramento no currículo. Utilizando-se de dados coletados de ambientes escolares londrinos, diversos em termos etnolinguísticos, eles analisam criticamente algumas das estruturas conceituais e teóricas em letramento e educação linguística "com o intuito de enriquecer e tornar mais complexos os pressupostos sobre os quais a compreensão desta diversidade pode se basear".

Procuram mostrar, ainda, como a "diversidade cotidiana e mundana e a heterogeneidade de contextos locais singulares podem permanecer dúbias tanto para os que as praticam, quanto para os que as planejam". A prática de língua e a prática de letramento podem ser dúbias no novo mundo globalizado e diverso, e apenas a combinação das abordagens de LA com o Inglês como Língua Internacional (ILI) podem ajudar os praticantes e os pesquisadores a lidar com esta complexidade (cf. também Blommaert, 2005 a respeito da sobrediversidade).

\section{Algumas abordagens nos Estados Unidos}

A relação das abordagens de LA ao trabalho nos Estados Unidos talvez seja bem mais complexa, uma vez que tem havido ali há muito mais tempo discussões sobre a escrita estudantil e o auxílio no ensino superior. 0 surgimento mais recente da "participação ampliada" na 


\section{Brian Street}

educação superior nos Estados Unidos levou à uma pesquisa relevante e à adaptação às práticas institucionais com o intuito de auxiliar a escrita estudantil, particularmente representada por abordagens como Escrita no âmbito das Disciplinas, Escrita no âmbito dos Currículos, Retórica, Gênero e Redação Acadêmica.

Entretanto, essas abordagens, ao contrário da perspectiva da abordagem LA no Reino Unido, não levaram tanto em consideração o equilíbrio entre o genérico e o específico e a significação de práticas variadas e perspectivas transformativas. Colegas nesses países e no âmago dessas tradições têm discutido essas questões atualmente, como se mostra evidente em muitas publicações recentes e relatos feitos em eventos acadêmicos.

Um artigo (Russell et al., 2009), escrito em coautoria por colegas de ambos os países, procura esboçar alguns elementos de cada país em relação ao outro e ao gênero, de forma especial. "À primeira vista", os autores reconhecem, "os dois países parecem ser bem diferentes. Cada um tem suas próprias tradições teóricas locais e metodológicas, e cada um implementa seus próprios termos: por exemplo, 'como sugerem seus respectivos títulos, um trata de redação, enquanto outro trata de letramento". Dessa forma, o diálogo futuro "pode prosseguir com muitas questões e congruências, mas com um cuidado acadêmico que se pode denominar saudável".

\section{Contribuição à prática}

Uma crítica à abordagem LA é que sua base é muito mais teórica e que não contribui com a prática. Eu prefiro contestar isto e fornecer aqui alguns exemplos de programas com os quais estive envolvido, trabalhando na King's College em Londres, na Universidade da Pensilvânia, nos Estados Unidos e na UFMG, no Brasil. Eu gostaria de discutir que a experiência nesses lugares, bem como em outros contextos, demonstra que a abordagem LA contribui, de facto, com a prática. Começarei com o debate político mais amplo que se voltou à aprendizagem de letramento em avaliações estatísticas estreitas e que fracassou ao não considerar as práticas locais de letramento de forma apropriada no contexto educacional. 


\section{"O enigma das graduações no Reino Unido e seu letramento de baixo nível"}

Um artigo discorrendo sobre "O enigma das graduações no Reino Unido e seu letramento de baixo nível" (Thes 11 Sept 2014) recorreu à avaliação de indicadores de performance como uma explanação possível para o que os autores apresentaram como "o enigma do letramento de baixo nível" entre os estudantes universitários do Reino Unido.

Os testes pareceram mostrar que esses estudantes não apresentavam um desempenho muito alto se comparados internacionalmente no âmbito de habilidades de letramento. Contestei essa abordagem relembrando que, recentemente, tornamo-nos cientes, no tocante à alfabetização de adultos, de que os índices de avaliações internacionais, tais como o Programa Internacional de Avaliação de Alunos (PISA) e o Programa para Avaliação Internacional das Competências dos Adultos (PIAAC) etc., não nos informam sobre os usos reais de leitura e escrita na vida cotidiana (Rogers e Street, 2012). Os testes podem avaliar quantitativamente as pessoas de modo a conduzir ao "enigma" relatado aqui, enquanto, em seu cotidiano, elas lidam com as práticas de letramento de forma perfeitamente adequada (Street, 2014). Sugeri que "talvez fosse o teste, e não os adultos, o enigma".

Uma perspectiva etnográfica sobre práticas de letramento permitenos remeter a essas questões, quando estudamos e analisamos os usos de tais práticas no cotidiano das pessoas, dentro de um país ou em vários países, sem cair na avaliação e confusão evidentes nessas pesquisas de cunho estatístico.

Assim, no contexto do Reino Unido, e aplicando esses debates aos estudantes ingressantes na universidade, a questão pode não ser o "baixo nível de letramento", mas, mais do que isso, as questões mais complexas associadas a como os estudantes aprendem a lidar com os diferentes gêneros e diferentes exigências de escrita no ensino superior. Pesquisadores estão frequentemente aplicando as perspectivas etnográficas mais que as estatísticas a esses processos, e disso resulta que referir-se ao "letramento acadêmico " (cf. Street, a ser publicado) de estudantes pode ser um caminho mais fértil do que a confusão acerca dos supostos "baixos níveis de letramento". 
Nas "entrelinhas" dos programas e disciplinas de escrita acadêmica na Universidade da Pensilvânia

Ministro regularmente um curso no programa de pós-graduação em Educação na Universidade da Pensilvânia e, em 2009, apresentei a ideia da abordagem LA a alguns estudantes que estavam na transição entre a graduação e cursos preparatórios que os levariam a ingressar no programa de doutorado. À primeira vista, eles estavam aparentemente bem afinados com as exigências de escrita da universidade, tendo obtido pelo menos uma graduação e, muitos, um mestrado. Todavia, à medida que aprofundamos as exigências com que estavam se deparando para escrever no nível em que passavam a ocupar, ficou evidente que eles teriam de aprender novos letramentos acadêmicos, os quais passamos a nos referir como "letramentos ocultos" (Street, 2009).

Enquanto os tutores e a instituição explicitavam as demandas referentes às características abertas deste tipo de escrita, geralmente através de listas pré-concebidas de coisas a serem abarcadas, como, por exemplo, a estrutura de um ensaio (i.e., introdução, teoria, métodos), nós, à luz da abordagem LA, rapidamente percebemos que o exigido nas avaliações de escrita acadêmica, muitas vezes, permanecia implícito. A isso é que demos o nome de "Letramentos ocultos".

Chamaram-nos a atenção especialmente aqueles critérios ocultos de que lançavam mão não apenas os supervisores, mas também os consultores de artigos para conferências e os revisores de revistas, implicando novas demandas e situações com que os estudantes em nível de doutorado começavam a se deparar. Dessa forma, os estudantes procederam ao desenvolvimento daquelas características que, esperavam, fossem formas menos estereotipadas e mais interativas, valendo-se de aspectos mais abrangentes da prática social da escrita acadêmica e reconhecendo a importância das abordagens especificas da disciplina, mais do que as abordagens gerais. Eles, por exemplo, identificaram características ocultas como "voz", "postura" e "so what question",

Subsequentemente, escrevi um artigo para a revista do departamento, intitulada Working Papers in Educational Linguistics, que incluiu as respostas de alguns estudantes e levou em consideração as implicações para aplicações mais extensas a favor da escrita acadêmica (Street, 2009). O curso será ministrado novamente em 2015, e este artigo está na lista de 
referências bibliográficas do curso como "Academic Literacies". A investigação e as descobertas continuam seguindo o princípio da abordagem LA, e outros artigos pesquisando os avanços são esperados tanto aqui, quanto em outros países em que a referida abordagem tem sido aplicada, como, por exemplo, no Brasil.

\section{O Brasil e a abordagem LA}

O Brasil está expandindo o número de estudantes no ensino superior. Com isso, discussões e problemas similares àqueles surgidos nos Estados Unidos e no Reino Unido aplicam-se, em certa medida, a esse país. Obviamente há fatores específicos no Brasil, tais como as origens culturais e sociais de estudantes indígenas e vindos do campo (cf. Castanheira et al., a ser publicado). Começou também a despertar certo interesse o fato de que os modelos tradicionais, as habilidades de estudo e a socialização acadêmica não explicam suficientemente os problemas enfrentados por estudantes pertencentes a essas origens "não-tradicionais".

O desenvolvimento do modelo de letramento acadêmico tem implicações significativas para a forma como as instituições lidam com essas questões. A resposta institucional - típica dos Estados Unidos e do Reino Unido - de fornecer cursos extras e tutores específicos para lidarem com os "problemas" de escrita - pode não ser suficiente, especialmente quando as características culturais e sociais peculiares de "novos" estudantes são levadas em consideração. Numa universidade brasileira, por exemplo, os responsáveis pelo programa indígena começaram a se afastar do foco tradicional nos estudantes e de como "corrigi-los" para, em vez disso, levar em conta questões mais amplas sobre as relações entre tutor e estudantes e sobre as expectativas próprias dos tutores de acordo com a disciplina - uma abordagem assinalada pela perspectiva da abordagem LA.

O foco em projetos de letramento acadêmico, assim, desloca-se dos estudantes como "problemas" para os tutores como praticantes profundamente envolvidos no processo de auxiliar os estudantes no exercício da escrita acadêmica. Plantões e seminários interativos tornam-se elementos-chave no projeto, expondo-os à gama de modelos de escrita acadêmica e discussão de formas nas quais o modelo de letramento acadêmico pode ajudar seus estudantes. 


\section{Brian Street}

Também no Brasil, estamos começando a encontrar estudantes pesquisadores que lidam com algumas questões envolvidas em seus trabalhos de doutorado, incluindo considerar o modelo de Letramento Acadêmico e suas implicações para a prática, bem como para a pesquisa. Uma proposta de doutorado de um desses estudantes, intitulada "O Lugar de Autoria na Produção Escrita no Ensino Superior" tem como objetivo compreender as práticas de letramento numa universidade federal no Brasil. Do mesmo modo, outro estudante está fazendo o seu doutorado com o título "Academic community expectations and students' difficulties: a study about the insertion of college students in academic literacies", também envolvendo a análise de dados coletados no Brasil. Ambos os doutorandos, que também lecionam em suas respectivas universidades, usufruem de bolsas, o que lhes permite participar de atividades na King's College, trabalhando com Brian e Ursula, assim como na Open University, com Mary Lea, ministrando palestras.

Houve também algumas conferências a respeito destes temas e há planejado um colóquio específico sobre LA para 2015. Em 2012, ocorreu o 60ำ Seminário do GEL (Grupo de Estudos Linguísticos de São Paulo). Durante esse congresso, realizou-se uma mesa redonda sobre "Theories and Objects in Applied Linguistics", que incluiu uma apresentação de Theresa Lillis (Reino Unido) cujo profícuo trabalho no campo do letramento acadêmico foi citado acima. Nessa mesa redonda, Lillis apresentou o trabalho intitulado "Reframing the object: the Contribution of 'Academic Literacies' to writing and research design". Também em 2012, no Rio de Janeiro (UFRJ), Theresa Lillis foi

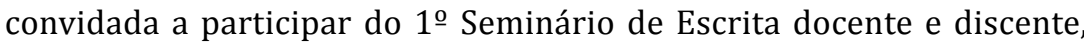
dedicado quase que exclusivamente ao tema "Letramento Acadêmico". Ela ministrou uma oficina-conferência que lidou com o tópico "Academic writing for publication: the politics of locality".

Em 2013, ocorreu a última de uma série de conferências em um evento intitulado SIGET: "Textual Genres in Multiple Levels of Human Activity" (de 03 a 06 de setembro de 2013 em Fortaleza, Ceará, Brasil). Os organizadores do evento dizem que "as perspectivas envolvidas no entendimento dos tipos de textos são tão infinitas quanto as línguas e as práticas heterogêneas; assim, é impossível não vincular os gêneros textuais a suas múltiplas esferas de atividades humanas; elas são os gêneros que efetivam a mediação entre as pessoas e que precisam de enunciação". Fez- 
se um evento intitulado "Writing Research Across Borders III" em Paris, em 2014, sendo possível reunir muitos dos pesquisadores internacionais citados acima, permitindo fazer-se sobressair o input francês a esses debates. Por exemplo, ali foi realizado um simpósio sobre "Academic Literacies and writing development", com estudos de caso do Reino Unido, da África do Sul e do Brasil.

As questões acerca do letramento acadêmico, assim, têm sido tratadas em relação aos gêneros, escrita acadêmico-universitária, redação em diversas disciplinas, socialização acadêmica e sob designações diversas em outros países - notavelmente nos Estados Unidos, no Reino Unido, no Brasil e na França. Ao mesmo tempo, questões específicas ao país e à cultura estão sendo tratadas, tais como aquelas associadas aos estudantes brasileiros indígenas ou oriundos do campo, e a relação de teorias da Retórica à escrita acadêmica na França.

\section{Rumos futuros?}

Por ora, a questão - à qual se refere este volume no Brasil - é: “como podemos aproveitar essas experiências crescentes e o trabalho teórico evidente na abordagem do letramento acadêmico para lidar com os problemas que dizem respeito a como auxiliar os tipos 'não tradicionais' de estudantes?". Além disso, não são apenas os estudantes, mas também os tutores, que - discutindo essa abordagem - podem se beneficiar ao se engajarem no modelo de letramento acadêmico, auxiliando a escrita dos estudantes nas disciplinas e trabalhando em programas para especialistas, tais como o Inglês para Fins Acadêmicos (ESP) e Inglês como Segundo Língua (ISL) etc. O livro, apropriadamente intitulado "Read, write, act and transform: an introduction to New Literacy Studies", é bastante adequado para levar adiante estas ideias, não só reconhecendo o trabalho dos New Literacy Studies (NLS), mas, também, fazendo avançar esse campo de estudos.

\section{Referências}

BLOMMAERT, J. Discourse: a critical introduction. Cambridge: CUP, 2005.

BLOMMAERT, J.; STREET, B.; TURNER, J. Academic literacies: What have we achieved and where to from here? Journal of Applied Linguistics, 4(1), 137-148, 2008.

CASTELLÓ, M.; DONAHUE, C. Eds. University writing: Selves and Texts in Academic Societies:Emerald Press: UK, 2012. 


\section{Brian Street}

CASTANHEIRA, M. L. G. C.; STREET, B. Researching academic literacies when we speak the same language, or do we? In: Special Issue of Pedagogies. Green, J. L.; Baker, W. D. Eds. (No prelo).

COFFIN, C.; DONOHUE, J. P. Eds. English for academic purposes: contributions from Systemic Functional Linguistics and Academic Literacies. In: Journal of English for Academic Purposes. Volume 11, Issue 1, Pages 1-78, 2012.

DELCAMBRE, I.; REUTER, Y. The French didactics approach to writing from elementary school to university. In: C. BAZERMAN, R.; KRUT, K.; LUNSFORD, S.; MCLEOD, S.; NULL, P.; ROGERS \& STANSELL, A. EDS. Traditions of writing research. New York/London: Routledge, 2010, p.17-30.

DELCAMBRE, I.; DONAHUE, C. University literacies: french students at a disciplinary 'threshold'? Journal of Academic Writing, 1(1), 13-28., 2011.

DONAHUE, T. Genre and disciplinary work in french didactics research. Perspectives on writing, 424, 2009.

GEE, J. P. Social Linguistics and literacies: ideology in discourse. Falmer Press: London and Philadelphia, 1990.

LANKSHEAR, C.; KNOBEL, M. New literacies: everyday practices and social learning. Open University Press: UK, 2003.

LEA, M.; STREET, B. Student writing and faculty feedback in higher education: an academic literacies approach. In: Studies in Higher Education. v.23, n.2 , 1998.

LEUNG, C. Second language academic literacies: converging understandings. In B. STREET; N. H. HORNBERGER. Eds. Encyclopedia of Language and Education. v.2. New York: Springer, 2008, p.143-161.

LEUNG, C.; STREET, B. Eds. English - a changing medium for education. Bristol: Multilingual Matters, 2012.

LEUNG, C.; STREET, B. Classroom Constructions of Language and Literacy Activity. In: Educating for Language and Literacy. Diversity Editors. Mastin Prinsloo and Christopher Stroud. Palgrave Macmillan, 2013.

ROGERS, A.; STREET, B. Literacy and development: Stories from the Field, NIACE, 2012.

RUSSELL, D.;LEA, M.; PARKER, J.; STREET, B. \& DONAHUE, T. Exploring notions of genre in 'academic literacies' and 'writing in the disciplines: approaches across countries and contexts'. In: Genre in a Changing World. Bazerman, C.; Bonini, A.; Figueiredo, D. Eds. Perspectives on Writing. Fort Collins, Colorado: The WAC Clearinghouse and Parlor Press, 2009. Disponível em: http://wac.colostate.edu/books/ genre/. Acessado em julho de 2016.

SCOTT, M.; LILLIS, T. Defining academic literacies research: Issues of epistemology, ideology and strategy. Journal of Applied Linguistics, 4, 2008, p.5-32.

STREET, B. (ed.) Literacies across educational contexts: mediating learning and teaching Caslon Publishing: Philadelphia, 2005. 
STREET, B. What's new in new literacy studies? Current Issues in Comparative Education 5(2) May 12, 2003. Disponível em: http://www.tc.columbia.edu/cice/. Acessado em Julho de 2016.

STREET, B. Hidden features of academic paper writing. In: working papers in educational linguistics. University of Pennsylvania, Spring, v.24, n.1, 2009, p.1-17.

STREET, B. The Puzzle of UK graduates and their low-level literacy (Letter to THES, 19.09.2014) In: response to an article in THES. 11 Sept., 2014.

WINGATE, U.; TRIBBLE, C. The best of both worlds? Towards an English for academic purposes/academic literacies writing pedagogy. Studies in Higher Education. 2012.

WINGATE, U. Academic literacy and student diversity: The case for inclusive practice, Multilingual Matters, London, 2015. 


\section{Promoção, operacionalização e funcionalidade do texto acadêmico}

Sulemi Fabiano-Campo

José Antônio Vieira

A escrita de uma monografia é, em certa medida, exemplo de desenvolvimento de ciência na graduação. A produção universitária sofre grande influência e transformações em consequência da pressão de agências de fomento e amparo às pesquisas estaduais e nacionais, mas é interessante reconhecermos que, considerando os conceitos históricos sobre a produção científica, podemos, de certa maneira, questionar alguns parâmetros das produções desenvolvidas na academia.

A monografia é um dos primeiros passos do aluno em relação à produção acadêmica e contato com uma fundamentação teórica. Parte daqueles que escrevem um texto monográfico tem, nesse momento, sua primeira experiência significativa de escrita científica. É uma situação de pressão e cobranças para atender aos procedimentos estabelecidos por uma metodologia baseada na articulação de perspectivas teóricas e análises de dados que permitirão a realização da investigação proposta.

Nesta investigação, respondemos ao seguinte questionamento: Quais os efeitos de sentido produzidos a partir do modo de utilização da voz do outro na escrita de textos acadêmicos? 0 objetivo geral é analisar de que forma uma teoria é utilizada por um aluno de graduação na escrita do texto monográfico. Já os objetivos específicos são: 1) analisar 
as marcações do outro (autor, conceito teórico, área de conhecimento) na escrita acadêmica; e 2) observar os efeitos de sentido produzidos por essa marcação. Para a realização desta pesquisa, selecionamos duas monografias defendidas recentemente, por alunos do curso de Letras de uma universidade pública do País.

Foram fundamentais para o desenvolvimento da pesquisa os conceitos de heterogeneidade enunciativa de Authier-Revuz (2004), que nos possibilitou analisar as marcações do outro na escrita monográfica; e de valor de troca e valor de uso de Rossi-Landi (1985) que, ao considerar a linguagem como trabalho linguístico, permitiu-nos observar as diferenças de uso e a funcionalidade social de uma teoria na escrita acadêmica.

Ao analisar o modo de utilização do discurso de outros autores na produção escrita de monografias, foi possível perceber os seguintes aspectos: 1) a existência de diferentes formas de se caracterizar a produção escrita de textos acadêmicos evidencia as relações entre o que se escreve e o que já foi produzido; 2) a escrita baseada na repetição de conceitos já desenvolvidos contribui com a produção de efeitos de sentido que podem questionar a funcionalidade da produção acadêmica; 3) a marcação do discurso de outro autor pode desenvolver um efeito de sentido que cria a ideia de que o texto produzido possui a função de promover um autor ou um conceito teórico; e 4) a construção do sentido de promoção pode garantir a inserção do trabalho numa comunidade ou grupo científico em detrimento da produção escrita que articula a teoria em análise de dados.

Essas situações apontam para a existência de um texto acadêmico que circula a fim de promover a fundamentação teórica, que normalmente se configura como argumentação e sustentação da produção científica. Assim, as marcações do outro na escrita acadêmica destacam afirmações alheias em detrimento do dizer do pesquisador.

\section{Do teórico-metodológico}

Nossa principal fundamentação teórica é a Análise do Discurso de linha francesa que apresenta os conceitos relacionados à heterogeneidade enunciativa do discurso. Fazemos uso de conceitos da sociologia e da filosofia ao nos remetermos, na análise dos dados, às noções de valores de uso e de troca tomadas do marxismo. 
Para o desenvolvimento desta investigação, apoiamo-nos em AuthierRevuz (2004), por defender, em seus estudos, que todo texto conta com a participação de outros discursos, isto é, a presença de dizeres diferentes daquele para quem o locutor constrói o enunciado. A pesquisadora denomina tal fato de heterogeneidade constitutiva do discurso, que pode ser mostrada, marcada ou não marcada. Isso nos permite analisar as produções escritas, neste caso, as monografias que selecionamos como corpus deste trabalho.

Ao tratarmos das diferenças do texto com funcionalidade social, fundamentamo-nos na perspectiva da linguagem como trabalho linguajeiro, conceito desenvolvido por Rossi-Landi (1985), que toma a linguagem como trabalho linguístico e mostra como são estabelecidos os valores funcionais e sociais de um discurso produzido.

Temos como hipótese do trabalho que a produção escrita desenvolva dois valores, o de uso e o de troca, estabelecendo uma relação dialógica entre aquele que é citado e aquele para quem o texto é escrito. Para desenvolver esses dois valores, precisamos encontrar, em sua estrutura, uma mobilização da voz do outro que funcione como fundamentação de um dizer próprio e demonstre operacionalidade dos conceitos teóricos em análise dos dados.

Baseamo-nos em estudos sobre as concepções de escrita de Coracini (2010) e Ciência de Kuhn (2011). A primeira apresenta a perspectiva de implicação daquele que escreve na produção que desenvolve, isto é, uma inscrição de si no texto que produz; e a segunda apresenta as revoluções científicas como realizações universais, fornecedoras de problemas e soluções para todo praticante de ciência, e define a ciência normal como toda ciência vigente nos períodos desprovidos de uma revolução científica.

Elencamos a teoria da heterogeneidade enunciativa de AuthierRevuz (2004) como ferramenta de análise, a fim de observar a organização e a composição da escrita acadêmica, no que diz respeito à marcação e à participação de outros dizeres no discurso, com o intuito de identificar os efeitos de sentidos gerados em razão dos modos de escrita de um texto acadêmico, visto que os sentidos da escrita podem se diferenciar, em razão da forma como relacionamos o discurso produzido àqueles que o atravessam. Como recurso de análise, observamos como os conectores e os diversos conceitos teóricos na escrita do texto acadêmico podem demonstrar a articulação entre a reflexão teórica, a metodologia do trabalho e a análise de dados. 


\section{Dos dados que analisamos}

Selecionamos duas monografias de autores e anos de defesa distintos. A escolha deu-se em razão de os alunos possuírem perfis diferentes: um deles, reconhecido como um "bom" aluno, realizou os estudos sem nenhuma reprovação e passou pela experiência de ser bolsista de iniciação científica durante a formação; o outro se formou com reprovações em seu histórico e sem a experiência de iniciação científica antes da produção do trabalho monográfico.

Os dados que recortamos das duas monografias analisadas foram retirados de partes do texto, nas quais se espera uma articulação da teoria apresentada com a análise de dados. E, justamente por não percebermos essa relação entre teoria e análise, recortamos esses dados. Outro critério utilizado para selecionar o corpus foi a observação de trechos da monografia em que havia muita repetição de um autor ou a identificação de uma quantidade excessiva de conceitos descritos em poucas linhas de texto.

\section{Monografia 001 (Aluno A)}

O aluno A concluiu sua graduação no primeiro semestre letivo de 2009, cumprindo o curso em dez semestres (dois semestres a mais que o tempo mínimo de formação do curso de Letras). Foi aluno do mestrado da mesma universidade onde se formou. 0 seu trabalho fundamenta-se na teoria da Análise do Discurso de linha francesa e tem como título "Dança do Chorado: efeitos de uma memória".

Os objetivos do trabalho não estão explícitos, são apenas compreendidos a partir da leitura do texto, como: "analisar a transcrição de um depoimento relatado sobre a Dança do Chorado realizado por um morador da cidade de Vila Bela da Santíssima Trindade em Mato Grosso, com o intuito de observar as condições de significação do sujeito do Chorado no século XVIII", investigar "os modos como os sentidos se constituem e se institucionalizam no Chorado da atualidade" e, por fim, "compreender como se constitui o efeito metafórico do Chorado do século XVIII para o Chorado da atualidade".

A monografia tem 37 páginas, divididas em: resumo; introdução; capítulo um, dedicado às considerações teóricas; capítulo dois, dedicado à descrição do corpus; capítulo três, dedicado à análise; considerações 
finais; e referências bibliográficas. 0 corpus do trabalho é a gravação de um depoimento concedido ${ }^{1}$ sobre a Dança do Chorado ${ }^{2}$. As palavras-chave do trabalho acadêmico são: memória discursiva, resistência, subjetividade, silêncio e deslizes dos sentidos. Na introdução do texto, apresentam-se o objetivo e os autores utilizados como fundamentação da pesquisa, sem justificação ou demonstração da relevância do trabalho realizado.

O primeiro capítulo da monografia é nomeado como "Considerações teóricas", presta-se à apresentação das teorias e conceitos teóricos que o aluno indica como fundamentação para o trabalho. 0 segundo capítulo intitula-se "Configuração do corpus" e faz a descrição e apresentação do corpusque o aluno pretendia analisar. Ao final do trabalho, temos um capítulo dedicado à análise de dados nomeado com o mesmo título da monografia.

\section{Monografia 002 (Aluno B)}

O aluno B concluiu sua graduação no segundo semestre letivo de 2011, em oito semestres, completando a formação no prazo mínimo estabelecido. 0 seu trabalho também utiliza como fundamentação teórica a Análise do Discurso de linha francesa e leva o título "Jornal e poesia: o Alencar espelhado no discurso da língua". Apresenta-se como objetivo: "investigar as práticas discursivas no espaço de dizeres dos jornais O Povo (1879) e A Opinião (1878)", para “verificar a constituição da subjetividade no espaço discursivo do jornal e da literatura, que circulou em Mato Grosso na segunda metade do século XIX". O trabalho é fruto da participação em um projeto de pesquisa com fomento e o corpus foi recortado do material coletado para o projeto de pesquisa coletivo. Também foi publicado em uma revista acadêmica de circulação regional.

0 trabalho não tem pergunta de pesquisa e possuiu 55 páginas, divididas em: resumo; abstract; apresentação; um capítulo dedicado à fundamentação teórica, nomeado "Primeiras (In)junções teóricas"; um capítulo dedicado à análise dos dados, intitulado "Outros no mesmo: por um funcionamento literário-discursivo no jornal"; um capítulo de considerações finais, que é chamado de "Palavras (quase) finais"; bibliografia e anexos.

\footnotetext{
${ }^{1}$ Consideramos como depoimento relatado, porque a transcrição foi feita a partir de entrevista. $\mathrm{O}$ aluno solicitou a um morador da comunidade que desse seu depoimento sobre a dança do Chorado.

${ }^{2}$ Dança típica de comunidades quilombolas, nesse caso, do grupo que viveu na região da cidade de Vila Bela da Santíssima Trindade, MT.
} 
Os efeitos de sentido no texto acadêmico: promoção, operacionalização e funcionalidade

No dicionário Aurélio, encontramos as seguintes acepções do termo promoção: do latim promotione, "ato ou efeito de promover. Elevação ou acesso a cargo ou categoria superior; ascensão"; do inglês promotion, "O conjunto de atividades que visam fortalecer a imagem de uma marca, instituição, indivíduo, etc., [...]" (Ferreira, 1999, p.1.648).

As acepções dicionarizadas da palavra "promoção" funcionam como um ponto de referência para conceituarmos o que estamos chamando de efeito de promoção. Compreendemos que a escrita pode, de acordo com sua organização, denotar a imagem de que a função do texto produzido possui a funcionalidade de promover o conceito ou o autor utilizado como fundamentação teórica do trabalho. Tal situação nos permite dizer que é possível construir uma imagem cujo autor ou o conceito citado pertencem a uma categoria superior em relação a quem escreve o trabalho que analisamos.

Há um ponto em comum entre o que consideramos como efeito de promoção de um autor ou conceito e o significado da palavra promoção apresentada pelo dicionário. A ideia de "ato de promover" é a essência de nossa conceituação do termo: característica do trabalho acadêmico inserido em uma comunidade científica pela exaltação e reprodução de outro, cuja escrita não se desloca do já dito e se limita a repetir ou a utilizar uma teoria, um autor ou um conceito teórico como propaganda, sem delegar-lhes "utilidade".

O efeito de sentido de promoção pode se desenvolver de várias maneiras. Neste trabalho, tratamos sobre os atos de promover um autor e um conceito teórico. 0 primeiro é caracterizado, a partir da marcação e estruturação da escrita, pelo uso de excessivas citações de um mesmo autor sem estabelecer relação com o discurso produzido ou articulação com a proposta de investigação. A escrita que se utiliza de várias citações para reproduzir o discurso de um autor específico constrói um sentido pelo qual o texto coloca em evidência o autor citado, ao invés das palavras de quem escreve. 0 segundo, a promoção de um conceito teórico, limitase ao emprego de um ou vários conceitos sem necessariamente conhecer suas condições de produção, sem explicar ou articulá-los com os dados que compõem a pesquisa. 
Uma escrita repetidora, que origina o efeito de promoção de um autor ou de um conceito teórico, não desenvolve, em sua estrutura, uma operacionalização deles para contextualizar sua investigação. Por essa razão, compreendemos que existe uma relação entre a falta de articulação e mobilização da fundamentação teórica utilizada na proposta de pesquisa e a produção escrita baseada na reprodução.

Sustentamos que tal utilização de uma teoria funciona como um modo de garantir a inserção e aceitação de um texto acadêmico em uma comunidade científica, mesmo que os conceitos teóricos não estejam operacionalizados (utilizados em análise de dados ou na metodologia, por exemplo) ou não tenham funcionalidade no trabalho em que são empregados. Além disso, dependendo da forma como são desenvolvidas as marcações do outro na escrita acadêmica, dar-se-á destaque àquilo que é citado do outro em detrimento do dizer do pesquisador.

Partindo dos conceitos de trabalho linguístico de Rossi-Landi (1985), tratamos sobre a funcionalidade social da produção escrita realizada. Remetemos à representação e à relevância da produção na sociedade, ou seja, como uma nova produção exerce função social na comunidade, contribuindo com o desenvolvimento dela, respondendo a questionamentos e desenvolvendo novos conhecimentos. Se a escrita não se desloca, dificilmente poderá contribuir de forma produtiva para a sociedade, pois ela funciona como mecanismo de exaltação do que já foi produzido.

Esclarecemos que a modalidade de escrita que promove autor ou conceitos se diferencia daquela que tem como objetivo a divulgação científica, considerando que uma se estrutura na repetição do já dito e a outra contribui com o desenvolvimento do conhecimento sobre a ciência, através de um aprofundamento sobre um tema com propósito de disseminar, vulgarizar e difundi-lo.

\section{Os efeitos de sentido da escrita de monografias: a promoção de um autor}

Ao começar a análise, chamou-nos a atenção a recorrência de citações de um mesmo autor na seção dedicada à resenha teórica. 0 capítulo de considerações teóricas é composto de oito páginas e 44 parágrafos. Nestes, verificamos 25 marcações explícitas da voz de outro autor, das quais 22 indicam uma autora reconhecida na academia. Observamos que, 
no capítulo dedicado para análise, há 14 citações em discurso direto, introduzidas por conectores que evidenciam uma tentativa de adequação ou concordância com o discurso citado, e 24 tentativas de reformulações parafrásticas ${ }^{3}$ de conceitos teóricos que, em sua maioria, foram apresentados nas citações diretas de Orlandi.

Analisamos a escrita do aluno por meio de excertos que continham as formulações do autor que tão recorrentemente é citado, assim, focamo-nos numa análise dos conectores empregados na seção dedicada à exposição da teoria que embasa a monografia. Essa recorrência é significativa e cria a imagem de que o texto tende a utilizar apenas um autor para fundamentar o discurso produzido no trabalho. Juntamente com essa situação, temos uma inversão do papel de quem escreve com aquele que é citado, o que desenvolve o efeito de sentido de promoção de um autor, por meio da construção de um discurso consolidado pela repetição de outro autor.

Reconhecemos que as condições de produção ${ }^{4}$ podem influenciar no trabalho realizado, porém analisamos como é constituída uma escrita que desenvolve um efeito de sentido de promoção, para, ao final do trabalho, discutir sobre a formação escrita e refletir sobre os processos que contribuem e influenciam os modos de utilização de teorias em uma produção acadêmica.

0 recorte transcrito a seguir foi retirado da primeira monografia que analisamos. Classificamo-lo como Excerto 1, do aluno A. 0 trecho que analisamos está no início do capítulo dedicado à análise. Tratase da apresentação de uma citação recuada que traz uma explicação sobre a diferença dos estudos da Análise do Discurso e dos conceitos de transmissão da Teoria da Comunicação. Selecionamos esse excerto para mostrarmos como aquele que escreve inicia o capítulo dedicado à análise de dados de sua investigação sem mencionar o objeto ou mesmo apresentar o capítulo de análise, seus objetivos e a proposta daquela parte do trabalho. 0 conceito utilizado como fundamentação do trabalho também não é apresentado.

\footnotetext{
${ }^{3}$ Conceito apresentado por Fuchs (1985), que explica as tentativas de se dizer sobre um mesmo assunto por meio de diferentes construções sintáticas.

${ }^{4}$ Segundo Possenti (1997, p.369), para a Análise do Discurso, o conceito de condições de produção exclui definitivamente um caráter "psicossociológico", mesmo na "situação concreta". Os contextos imediatos somente interessam na medida em que, mesmo neles, funcionam condições históricas de produção, ou seja, os contextos fazem parte de uma história
} 
Anteriormente ao dado que recortamos, há um capítulo dedicado à transcrição do depoimento relatado de um morador da comunidade quilombola de Vila Bela, nomeado como Sr. Elísio.

\title{
Excerto 01 - Aluno A
}

\begin{abstract}
Conforme Orlandi (2002:21), não podemos considerar o depoimento relatado apenas como um código, ou mero meio de transmitir informações.

Para a Análise de Discurso, não se trata apenas de transmissão de informação, nem há essa linearidade na disposição dos elementos da comunicação, como se a mensagem resultasse de um processo assim serializado: alguém fala, refere alguma coisa, baseando-se em um código, e o receptor capta a mensagem, decodificando-a. $\mathrm{Na}$ realidade a língua não é só um código entre outros, não há essa separação entre emissor e receptor, nem tampouco eles atuam numa sequência em que primeiro um fala e depois o outro decodifica etc. Eles estão realizando ao mesmo tempo o processo de significação e não estão separados de forma estanque. Além disso, ao invés de mensagem, o que propomos é justamente pensar aí o discurso.

Como já discutimos sobre a noção de leitura (Orlandi, 2004), no relato, por se tratar de um material simbólico, não podemos, na perspectiva da A. D, visar compreender o que esse texto está querendo dizer, mas compreender como o discurso faz significar determinados efeitos de sentidos e como esses efeitos de sentidos se significam e funcionam. Em relação às discussões de Orlandi $(2002,2004)$, compreendemos o relato como o espaço simbólico do discurso sobre a Dança do chorado. Neste material simbólico de análise, os sentidos que se significam e que funciona fazem a partir de um imaginário de unidade e de autoria. De acordo com Orlandi (2001:65), o imaginário de unidade de sentidos produz a textualidade e o discurso imaginário da função-autor.

Falando da função-autor tenho dito o que ela constrói uma relação organizada - em termos de discurso - produzindo um efeito imaginário de unidade (com começo, meio, progressão, não contradição e fim). E a isto chamo de textualidade. Toda vez que tenho isso, tenho a função autor, colocando imaginariamente o sujeito na origem do sentido e sendo responsabilizado pela produção.

Interessante ressaltar que esse imaginário de textualidade ocorre pelo gesto de interpretação. É o gesto de interpretação que possibilitará a materialização do simbólico pelo discurso. No depoimento sobre o Chorado, esse imaginário de unidade dos sentidos pode ser compreendido ao tratar de maneira sequencial o primeiro, o segundo e o terceiro momento da Dança do Chorado. (p.20-21).
\end{abstract}

Na linha 01, há o uso do conector "conforme", que marca um controle do processo de comunicação, tal como definido por Authier-Revuz (2004). É uma marcação de heterogeneidade explícita de concordância com a voz do outro, seu uso indica conformidade do eu com o já-dito que é referenciado. Nesse caso, aquele que escreve evidencia a afirmação que faz com a voz do outro; não há um enunciado próprio do texto ou uma articulação do dizer produzido mediante o uso de discurso indireto ou mesmo de comentários do autor.

Nota-se que, para construir um discurso de adequação ou concordância com o outro, o aluno desenvolve uma escrita na qual inclui seu próprio discurso apenas para concordar com o discurso ao qual nos remete por meio da citação (linhas 03 a 13) ou para adequar-se a ele. Essa citação 
faz alusão aos conceitos de código e transmissão e é empregada numa tentativa de explicar o porquê de se utilizar a teoria da Análise do Discurso como base de fundamentação da análise do corpus. No entanto, o autor da monografia não desenvolve ou explica a diferença entre os conceitos de "transmissão de informação" e "processo de significação". Além disso, ele não faz comentários ou teorizações; a remissão e a apresentação dos conceitos de transmissão e código são realizadas pela autora citada. Não se realiza, por conseguinte, a mobilização do dizer de quem escreve e nem sua articulação com o discurso do outro que é citado.

Na linha 14, há uma marcação do mesmo autor da citação recuada, apresentada após a locução "Como já discutimos" para fazer remissão à "noção de leitura" do autor marcado. Não temos desenvolvimento do conceito de leitura nem a discussão a que se fez alusão. Observamos uma marcação nova do mesmo autor para apresentar outro conceito - o de "material simbólico" e remeter à teoria utilizada como fundamentação teórica.

Na sequência do texto, na linha 16, há uma marcação em itálico de uma concepção do autor citado, que serve para introduzir, na linha 17, a ideia de efeitos de sentido sem conceituar ou explicá-la. É como se fosse pressuposto que todos sabem o que o texto e a autora que é citada em diversos momentos querem passar ao falar sobre efeito de sentidos.

Na linha 18, utiliza-se a locução "em relação" como forma de remeter a conceitos que, supostamente, todos os leitores conhecem, pois não é desenvolvida uma reflexão sobre as "discussões de Orlandi". 0 único referencial são as citações diretas apresentadas no decorrer do texto que consideramos como mais uma marcação do discurso de outro autor, como formas de apresentar os conceitos do dizer referenciado.

Nas linhas 19 e 20, o autor do texto tenta estabelecer uma relação entre um conceito teórico e o corpus que se propôs a analisar. Porém, não há desenvolvimento do conceito ou articulação com o corpus. Pressupõese que todos os leitores compreenderão o que se quer dizer com "relato como um espaço simbólico do discurso da Dança do Chorado", mas não há explicação sobre o que é "espaço simbólico" ou mesmo sobre o que é o "discurso da Dança do Chorado".

Ao final, nas linhas 21 e 22, uma nova marcação aparece. 0 uso do conectivo "De acordo", seguido do nome do autor, novamente citado, sinaliza uma tentativa de concordância e conformidade. Na sequência, outros conceitos são apresentados sem explicação ou conceituação, como, 
por exemplo, "imaginário de unidade e de autoria" e "discurso imaginário da função-autor". Esses conceitos são desenvolvidos em seguida, mas por meio de uma nova citação direta da mesma autora já citada por diversas vezes.

A análise parece repetitiva em consequência da repetição maciça de marcações de uma autora em citações diretas ou em tentativas de paráfrases, como ocorre entre as linhas 14 e 22, que revelam um modo de escrita organizado de forma a dar voz para o autor citado.

Da linha 23 a 28, há, novamente, uma citação direta recuada, que apresenta o conceito teórico citado na linha 22 - "função-autor" -, que não foi conceituado por aquele que escreve, mas comentado a partir de paráfrases. A escrita apresentada no texto que analisamos, demonstra que aquele que escreve apresenta e cita diversos conceitos, dando como referência discursos de uma autora reconhecida e consolidada para conceituar e explicar o que menciona. Não vemos, porém, a articulação de comentários com os discursos do autor que é citado ou com o corpus da pesquisa do graduando. Tal característica é perceptível no texto desenvolvido entre as linhas 29 e 33, quando aquele que escreve relaciona os conceitos apresentados pelas citações do outro com o "depoimento sobre o Chorado", que é apresentado como corpus da investigação.

0 texto apresenta, portanto, diversos conceitos, mas não os explica ou os articula com o que se propõe a analisar. Podemos utilizar, como exemplos, os casos de "imaginário de textualidade", na linha 29, "gesto de interpretação" e "materialização do simbólico", na linha 30, e "imaginário de unidade dos sentidos", na linha 31. Esses conceitos teóricos não são apresentados, explicados e conceituados, e apenas sua apresentação, juntamente com as citações, não permite entender os conceitos nem dar conta do objetivo proposto no trabalho.

Outro fato a ser considerado é que a referência que o aluno faz a Orlandi (2002) retoma conceitos que não são especificamente dessa autora. São, sim, termos consolidados na comunidade linguística, como "material simbólico", "significação", "transmissão de informação", entre outros, cuja origem o aluno atribui à autora citada. Podemos entender esse equívoco como uma dificuldade própria desse momento de escrita, pois é um período de aprendizagem do graduando, e a monografia pode ser considerada como a primeira experiência de escrita acadêmica que resulta de uma investigação. 
Esse tipo de produção que desenvolve um efeito de promoção e em que o autor se utiliza da alegação da dificuldade de escrever como forma de justificar as falhas de escrita é um exemplo de trabalho, muitas vezes, reconhecido na universidade. Além de se aceitar essa produção como um trabalho inicial de monografia, esse modo de escrita que promove o autor é aceito como próprio à pesquisa, criando a ilusão de que contribui com a produção científica na universidade, o que também questionamos, considerando a quantidade e a popularização de trabalhos com essas características, os quais ganham a cada dia mais espaço e incentivo.

\section{Os efeitos de sentido da escrita de monografias: a promoção de conceitos teóricos}

0 modo de escrita que analisaremos, no Excerto 02, aproxima-se do que vimos no anterior, porém, temos outro tipo de efeito de sentido construído. A diferença está na forma do sentido produzido. 0 texto tem como característica o encadeamento de vários conceitos teóricos que não são mobilizados e operacionalizados em análises. Os termos de uma determinada perspectiva teórica não são necessariamente bem definidos, explicados ou desenvolvidos, revelando um efeito de sentido pelo qual o texto os promove e os oferece como instrumento de análise do corpus do trabalho. Nesse caso, temos um exemplo de efeito de sentido de promoção de conceitos teóricos.

\section{Excerto 02 - Aluno B}

\footnotetext{
01 Alguns consideram o já-dito enquanto um fechamento dos sentidos, pois este, em 02 certa medida, delimita, imobiliza. Entretanto, podemos pensar, com Orlandi (2009, p.9) 03 "[...] que aquilo que se diz, uma vez dito, vira coisa no mundo: ganha espessura, faz 04 história". Desse modo, apontar para o estabelecimento do não-estabelecido e 05 questionar a consciência hegemônica (o sentimento) dessas distinções no homem de 06 linguagem, fornece fôlego para a nossa concepção de trabalho, qual seja, a língua 07 pensada por uma teoria materialista de linguagem. Também, a questão da memória 08 se mostra sensível quando, sobretudo, "[...] ela opera sob a forma da evidência dos 09 sentidos, aparecendo [...] nas suas falhas" (PAYER, 2009, p.42).
}

Na linha 01, aparece o pronome indefinido "alguns", uma palavra não anafórica, ou seja, sem relação semântica com outro termo ou sentido referente. Como afirma Neves (2000, p.534), são "considerados indefinidos de identidade os pronomes cuja referência não pode ser identificada". A 
utilização desse pronome funciona, então, como um recurso linguístico que marca a indefinição da referência que o aluno faz aos autores que apresentam o conceito linguístico de "já-dito" na linha 01 e marca, de certa maneira, um distanciamento do que é citado naquele momento. Por sua vez, a marcação por meio do uso de "entretanto" funciona como marca de adequação e adesão ao que é dito a seguir e de negação à primeira referência realizada, como podemos confirmar na linha 02 . 0 uso do conector acrescenta, portanto, uma marca de adversidade em relação ao trecho iniciado pelo pronome indefinido. 0 aluno, assim, recusa um dizer alheio e indefinido para filiar-se a outro, o da autora que aparece predominantemente no seu texto.

0 uso do conector indefinido para marcar uma contrariedade com um autor não referenciado, evidência o discurso de outro autor utilizado como fundamentação teórica do trabalho. Isso, em conjunto com os outros usos aqui analisados, provoca um efeito de sentido durante a leitura. 0 que compreendemos como uma forma de promoção de um conceito.

Nesse caso, a forma de organização das marcas de outros discursos na produção escrita constrói entre as palavras um jogo que nega certos discursos ou os invalida, como o que vemos na linha 01 com o uso do conectivo "alguns". 0 texto desqualifica ou recusa o conceito de já-dito como um "fechamento de sentidos". Esse jogo de palavras contraria a definição corriqueira do termo e reforça a aproximação com a conceituação apresentada pela voz de Orlandi, que, além de marcada, é considerada, na escrita do aluno, como a voz correta e verdadeira, que deve ser seguida em oposição àquelas apresentadas indefinidamente na linha 01. Ao mesmo tempo, a produção daquele que escreve não se desenvolve, ela apenas consolida e reproduz outros discursos já reconhecidos.

Esse efeito de promoção é caracterizado pelo destaque dado aos conceitos de uma determinada voz, no caso, a de Orlandi. Tal modo de escrita cria um efeito de sentido que entendemos como forma de promover o outro. É caracterizado pelas marcações da voz de outros autores por meio de citações recuadas, paráfrases e/ou reformulações de um discurso conhecido. Essa estrutura de escrita, involuntariamente, passa a ideia de que o discurso do outro tem prestígio especial, uma prática que pode ser observada no "jogo" da academia, ou seja, é uma situação comum na universidade.

Temos assim a criação da imagem de que a reprodução de um discurso ao qual estamos filiados e com o qual estabelecemos ligação e 
aproximação, seja por ser de um autor reconhecido, seja para sermos respeitados pelos pares que utilizam a mesma teoria ou conceito como fundamentação é aceita como produção científica, em razão do efeito de sentido de promoção de um autor respeitado e reconhecido e não pela relevância da investigação realizada.

Isso contraria, em certa medida, alguns critérios necessários para reconhecer um texto acadêmico enquanto produção científica, como a construção de valor científico (grau de relevância para a ciência) através da articulação entre conceitos teóricos e análise de dados. Essa articulação poderia auxiliar o jovem pesquisador a responder os questionamentos que o levaram a propor determinada investigação.

Não estamos problematizando vontades ou intenções, mas refletindo sobre a possibilidade de que as diferentes formas de escrita estejam ligadas às maneiras como realizamos a articulação do discurso de outros autores com aquele que estamos produzindo. Além de constitutiva, a alteridade incita-nos a estabelecer relações com os discursos já realizados, contudo, conforme estruturamos um dizer, podemos construir efeitos de sentido que nem sempre condizem com o que estamos propondo, mas que não impedem que o trabalho se constitua como produção.

Ao mencionarmos ligação, aproximação e filiação de um pesquisador a uma teoria, referimo-nos ao conhecimento que aquele que escreve tem sobre autores ou teorias para desenvolver seus trabalhos e atividades durante a formação acadêmica. Para realizar uma produção escrita, desenvolve-se um vínculo com um ou mais pressupostos teóricos que, em sua maioria, são instituídos por um autor reconhecido que já tenha contribuído com a produção científica. São esses autores que estudamos durante a formação que utilizamos em citações com o objetivo de confirmar nossos dizeres e garantir o caráter científico das pesquisas que realizamos.

Entretanto, dependendo da forma de se relacionar com uma teoria ou com um determinado autor - isto é, como se utiliza os conceitos e discursos de outros autores -, da experiência de orientação vivenciada e de diversas outras questões, os universitários desenvolvem diferentes formas de produção escrita, e uma delas pode contribuir para que as investigações de iniciação científica, como de monografias, estruturem-se por meio da repetição e de citações soltas de autores renomados sem articulação com a proposta inicial do trabalho. Trata-se de escrever um texto 
cuja teoria não funciona, predominantemente, como subsídio do trabalho. Ao contrário, a produção escrita é que subsidia a teoria, colocando-a em evidência, exaltando-a, o que constrói um sentido de que o texto promove quem é citado.

Algo parecido pode ser percebido no Excerto 2, quando, na referência a Orlandi, na linha 02, o aluno faz uso da locução verbal "podemos pensar" em conjunto com a preposição "com". A marcação evidencia que os pensamentos dele sobre as teorias que apresenta não são apenas mediados pela voz que cita, mas são literalmente do outro. É interessante observar essa ocorrência, lembrando que Authier-Revuz (2004), ao afirmar que a organização do discurso se dá a partir do outro, não exclui dessa relação o eu. A utilização da locução verbal "podemos pensar" como conectivo para marcar a voz do outro parece demonstrar que o texto produzido é uma forma de reproduzir a maneira de pensar do autor citado e que não temos uma reflexão daquele que escreve.

Ainda analisando o dado anterior, notamos que o uso da conjunção conclusiva "desse modo", na linha 04, estabelece uma retomada da citação de Orlandi nas linhas 02 a 04. Tal uso é uma modalização em discurso segundo uma maneira de quem escreve concordar com o autor que foi citado antes do uso do conectivo em questão, o que pode ser considerado inicialmente como um argumento de autoridade, uma forma de confirmar um discurso através do dizer de um autor já reconhecido na academia.

As formas de marcação do discurso de outros autores na escrita dos textos que analisamos controlam o discurso do aluno. Conforme percebemos, em grande parte, evidenciam a voz do outro, do autor reconhecido. 0 texto faz remissão a conceitos que não são empregados no trabalho, não funcionam como categorias de análise e não lhe dão sustentação teórica, desenvolvendo-se um sentido de que o texto produzido é apenas um mecanismo de demarcação da filiação teórica de quem escreve a uma autora renomada e reconhecida como autoridade sobre a teoria utilizada.

Na linha 07, o conectivo "também", um advérbio com valor de adição e ênfase, é utilizado para destacar algo que será incluído no texto. Nesse caso, inclui-se o conceito de memória antes da referência ao discurso de outro autor. Temos a menção de um novo termo da teoria da Análise do Discurso, "memória", que novamente não é explicado ou descrito por quem escreve; sua conceituação é desenvolvida depois, a partir de uma nova citação do discurso de outro autor. 
Num segundo momento, esse mesmo "também" funciona como um recurso de antecipação da citação de Payer. É uma maneira diferente de marcar a voz do outro. Dessa vez, o conectivo apresenta a voz citada nas linhas 08 e 09 em uma ilha textual que, segundo Authier-Revuz (p.16, 2004), é uma das formas de marcação da heterogeneidade discursiva, caracterizada pela transcrição.

A utilização do conectivo "sobretudo", na linha 08, confirma a tentativa de se estabelecer relação com o termo que o conectivo "também" introduziu e, assim, remeter à voz do outro que é citada. Observamos que esses conectores são utilizados como mediadores da citação e como uma marcação do discurso do outro que é citado, como constatamos com a marcação do dizer de Payer nas linhas 08 e 09, apresentado pelos conectores "também" e "sobretudo", que antecipam e demonstram uma aproximação com a citação do autor.

Além das linhas 08 e 09, encontramos ilhas textuais nas linhas 03 e 04. Elas são formas de modalização autonímica, ou seja, de marcação do discurso do outro dentro do próprio discurso.

A conotação autonímica pode ser representada pela apresentação de discursos entre aspas, em itálico etc. Essas formas de conotação funcionam como um argumento de autoridade na escrita daquele que redige o texto. Trata-se de uma maneira de argumentar que consiste em utilizar o discurso de um autor reconhecido pela academia para confirmar o que estamos dizendo, como forma de garantir a veracidade e obter respaldo científico para o que escrevemos.

No caso do Excerto 2, vemos que a escrita desenvolvida aponta para um encadeamento de autores que confirmam o dizer daquele que foi marcado, mas não demonstram uma posição enunciativa daquele que escreve nem apresentam uma citação que confirme um dizer dele. A produção escrita é caracterizada pelas vozes dos outros autores citados, como Payer nas linhas 08 e 09, que complementam o conceito apresentado por Orlandi nas linhas 02 e 04 .

A escrita desenvolvida com essas marcações que produzem um efeito de promoção dos conceitos teóricos também é objeto de reflexão sobre o silenciamento da voz de quem escreve. A produção em questão, ao se utilizar das citações de diferentes autores e desenvolver o sentido de promoção, sem articular os pressupostos teóricos com uma análise de dados, apaga a posição de enunciador do aluno, que se reduz ao estatuto 
de suporte, de porta-voz do dizer de outro autor, não realizando o trabalho que se propôs a fazer, mas, mesmo assim, tendo sua produção reconhecida pela comunidade científica.

Como discutimos o encadeamento de conceitos teóricos sem explicação, apresentamos, nas linhas abaixo, uma síntese dos dados, que confirma nossa hipótese, considerando que o excerto já não está muito próximo.

01: conceito de "já-dito"

04: de "não-estabelecido"

05: de "consciência hegemônica"

07: de "teoria materialista de linguagem" e "memória"

A análise do Excerto 2 revelou a presença de marcas, conectores e citações, que referenciam outras vozes no texto do locutor através de discurso relatado indireto. Para Authier-Revuz (2004, p.12), essa demonstração de heterogeneidade explícita do discurso é caracterizada pelo comportamento do autor como tradutor, pois "fazendo uso de suas próprias palavras, ele [o aluno] remete a outro como fonte do 'sentido' dos propósitos que ele relata”.

Para a metodologia de iniciação científica, as marcações da voz do outro funcionam, nas produções escritas e investigações, como argumentos de autoridade, que são utilizados a fim de confirmar e sustentar aquilo que se defende e analisa, sem com isso construir uma ideia de que o texto exalta e promove autores da teoria da Análise do Discurso. Contudo, no caso analisado, vemos uma escrita que demarca as vozes do outro e reproduz os conceitos teóricos de autores consolidados, originando o efeito de promoção do autor citado ou do conceito que é, por diversas vezes, referido.

\section{Considerações finais}

Iniciamos esta seção retomando a pergunta de pesquisa que desencadeou nossa proposta de investigação: Quais os efeitos de sentido produzidos a partir do modo de utilização da voz do outro na escrita de textos acadêmicos?

As análises realizadas nos confirmam que o uso de fundamentação teórica nos trabalhos de investigação é necessário para a produção de trabalhos acadêmicos como monografias. 0 uso do discurso do outro é uma prática que garante a credibilidade de produções escritas, funcionando como argumentação e dando sustentação do dizer daquele que escreve. 
Ao cumprir nossos objetivos de analisar as marcações do outro (autor, conceito teórico, área de conhecimento); e observar os efeitos de sentido produzidos por essa marcação, foi possível verificar a existência de diferentes modos de um jovem pesquisador se relacionar com uma teoria.

Com isso, observamos que uma produção escrita pode evidenciar o desenvolvimento de efeitos de sentidos no qual o texto perde a funcionalidade de propor algo novo e produtivo para o universo acadêmico para promover o dizer utilizado como referência, seja na forma de um conceito teórico ou na marcação de um autor reconhecido.

Ao analisar os efeitos de sentido desenvolvidos a partir da forma de utilização do outro na produção escrita, verificamos que a produção de determinados sentidos, como esse da promoção, pode garantir a aceitação e a aprovação do trabalho acadêmico pelos pares de quem escreve, bem como legitimar sua publicação em revistas e boas avaliações em bancas de monografias. Isso independentemente do trabalho desenvolver uma articulação e mobilização da fundamentação teórica com uma análise de dados.

A análise das monografias nos permitiu perceber a construção de uma produção escrita que não realiza uma análise do corpus que apresenta como dado, mas sim o desenvolvimento de uma escrita a partir de repetições da teoria de outro autor. Ressaltamos que nosso propósito foi analisar esse uso para refletir sobre os modos de escrita que são aceitos e entendidos como produções de trabalhos acadêmicos e não para acusar ou culpabilizar aquele que escreve desse modo.

Entendemos que quem escreve um texto é responsável pelo seu dizer e que, em situações como as que analisamos, produzem-se certos efeitos que geram o sentido de que a responsabilidade do que é dito no texto é do autor que é citado e não daquele que escreve, considerando qual voz realiza a apresentação dos conceitos e quantas vezes um mesmo autor é marcado. Observamos que esse modo de escrita repetidora dá origem a uma ideia de hierarquia de conceitos teóricos e cria a imagem de que o texto acadêmico funciona como meio de transmissão e repetição do já-dito.

Por fim, não desconsideramos a presença do outro como parte constitutiva do dizer. Entendemos que há diversos modos de utilizar ou dar voz ao dizer do outro. Assim, podemos utilizar a voz do outro como argumento ou construir um modo de escrita baseado na repetição. Considerando, nesse último caso, a possibilidade de uma inversão 
do papel de quem escreve com a referência teórica utilizada, ou seja, o discurso daquele que escreve desenvolve a função de evidenciar a participação do outro que é citado.

\section{Referências}

AUTHIER-REVUZ, J. Entre a transparência e a opacidade: um estudo enunciativo do sentido. Tradução de Leci Borges Barbisan e Valdir do Nascimento Flores. Porto Alegre: EDIPUCRS, 2004.

CORACINI, M. J. R. F. Discurso e escrit(ur)a: entre a necessidade e a (im)possibilidade de ensinar. In: CORACINI, Maria José Rodrigues Faria; ECKERT-HOFF, Beatriz. (Org.). Escrit(ur)a de si e alteridade no espaço papel-tela (formação de professores, línguas materna e estrangeira). Campinas: Mercado de Letras, 2010, p.17-50.

FERREIRA, A. Aurélio século XXI. 3ed. Rio de Janeiro: Nova Fronteira, 1999, 2128p.

FUCHS, C. A paráfrase linguística: equivalência, sinonímia ou reformulação? Caderno de Estudos Linguísticos. Tradução de João Wanderlei Geraldi. Campinas: n.8, 1985,p.129-134.

KUHN, T. S. A estrutura das revoluções científicas. Tradução de Beatriz Vianna Boeira e Nelson Boeira. 10ed. São Paulo: Perspectiva, 2011.

NEVES, M. H. M. Gramática de usos do português. São Paulo: Unesp, 2000.

POSSENTI, S. Indícios de autoria. In: PERSPECTIVA - revista do centro de ciências da educação. Florianópolis: Ed da UFSC, 2002.

ROSSI-LANDI, F. A linguagem como trabalho e como mercado: uma teoria da produção e da alienação linguísticas. Tradução de Aurora Fornoni Bernardini. São Paulo: Difel, 1985.

POSSENTI, S. Sobre as noções de sentido e de efeito de sentido. Cadernos da F.F.C.: Análise do Discurso, Marília, v.6, n.2, p.3-11, 1997. 


\section{A escrita acadêmica em provas. A descontinuidade na mobilização teórica.}

Cármen L. H. Agustini

Mariana da Silva Marinho

\section{Palavras iniciais}

A escrita, forma simbólica que permite uma subjetivação, em que aquele que escreve diz de si e de sua relação com a língua escrita e com o conhecimento, ganha especificidades no espaço acadêmico. Essa escrita (acadêmica) possibilita ao aluno a sua inscrição em um outro espaço, que não é o de mera reprodução das teorizações vigentes, mas também de sua produção, haja vista que, quando um pesquisador escreve um artigo científico, por exemplo, sua escrita está em função de divulgar resultado(s) de sua pesquisa para seus pares. Trata-se, portanto, de uma escrita que (pres)supõe um público-interlocutor específico. A partir dessa colocação, o presente trabalho visa problematizar o processo de assunção do aluno à escrita acadêmica, por meio de um olhar sobre a sua relação com diferentes saberes acadêmicos com os quais ele tem contanto-confronto e que ele tem que mobilizar para atender às demandas de escrita que lhe são postas na sua vivência acadêmica.

Para proceder à execução deste trabalho de pesquisa, mobilizamos as teorizações de Émile Benveniste sobre enunciação falada e enunciação escrita e, a partir de nossa leitura, propomos uma diferenciação entre falar e dizer, por um lado, e ouvir e escutar, de outro. Essa diferenciação ajudar- 
nos-á a mostrar, via análise, a descontinuidade da relação do locutorscriptor com os saberes ensinados em aulas de graduação e em aulas de pós-graduação, de modo que há saberes que chegam ao aluno como uma espécie de "barulho" incompreensível, enquanto outros lhe chegam como um dizer, organizado, fazendo-se lhe compreensível, porque o toca de alguma maneira.

O dizer, por conseguinte, é relativo à semantização da língua no processo de sua conversão em discurso. Ou seja, há dizer quando o colocutor, nesse caso específico, o aluno, atribui sentido àquilo que lhe chega do dizer do professor; trata-se de um dizer que ele compreende porque consegue associá-lo a conhecimentos já apr(e)endidos, de modo que ele consegue planificá-lo em seu repertório de saberes. Planificá-lo aqui funciona em dois sentidos possíveis: (1) no sentido de planejamento e organização e (2) no sentido de tornar plano, de entrar na sintagmatização a partir de sua seleção nas e pelas redes de associação.

Para tanto, baseamo-nos na análise de algumas provas, a fim de compreender e explicitar o que ocorre, quando, no processo de escrita em que o aluno deveria mobilizar uma determinada teoria para responder a questões de uma prova, a mobilização teórica é ou não é bem-sucedida. Além disso, analisamos o modo como acontece ou não a mobilização teórica, a fim de mostrar a relação subjetiva ali implicada. Nossas análises pautam-se nos pressupostos da teorização de Émile Benveniste sobre a apropriação da língua (escrita) no processo de sua conversão em discurso e sobre o manejo da língua como atividade de pensar e de raciocinar. Para tanto, questionamos: (a) em que a mobilização teórica implicase à apropriação da língua (escrita), no processo de escrita da resposta à questão de prova no espaço acadêmico? (b) como essa implicação se marca no escrito do aluno?

0 processo de escrita de textos acadêmicos, em particular a escrita de textos-respostas em prova, traz subjacente não só a apropriação da língua escrita, mas também a mobilização da teoria que a questão demanda a ele. Se o aluno não consegue se inscrever teoricamente, sua escrita permanece exorbitando à ordem do discurso acadêmico e, por isso, parece traduzir-se em escrito de senso comum, desprovido da trama conceitual que o definiria e o (de)limitaria como um escrito acadêmico.

Nesses casos, muitas vezes o aluno re-diz o fato linguístico a ser analisado sem que sua escrita demonstre e mostre que a teoria estudada o 
toca de alguma forma, ou seja, que essa teoria lhe faz sentido; essa escrita, assim constituída, mostra que o aluno não (consegue) mobiliza(r) a teoria na escrita de sua resposta e, por isso, não é bem-sucedido na questão. Se o homem é o ponto de interação entre a vida mental e a vida cultural como fora colocado por Benveniste, o que poderia estar acontecendo nesse mo(vi)mento de escrita? Partindo do próprio Benveniste, poderíamos dizer que há uma falha nessa interação, já que, no repertório cultural a que o aluno está investido por herança, a vida mental não encontrou um estofo que lhe propiciasse condições de associação e, assim sucedendo, a teoria estudada não é significada na e por ele, apresentando-se lhe como uma espécie de "barulho", que não lhe diz algo que reverta em compreensão. Nesse caso, aquilo que o professor disse na aula e que ele leu nos textos referenciais lhe chegou como algo que fora dito em uma "língua desconhecida" e que, por isso, permaneceu fora de uma zona de compreensão possível.

A partir disso, entendemos que a escrita acadêmica não é um mero modo de (re)produção de discursos teóricos com os quais o aluno tem contato-confronto no espaço universitário. Inscrever-se no e pelo espaço universitário implica lidar com demandas e coerções específicas, bem como estabelecer um espaço de responsabilidade enunciativa, que lhe permita ir além da (re)produção de conhecimentos, ou seja, que (re)vele traços subjetivos de uma mobilização teórica do conhecimento ali vivenciado.

\section{Contribuições em e por Émile Benveniste para abordar a escrita (acadêmica)}

Embasarmo-nos nas teorizações de Émile Benveniste sobre a apropriação da língua no processo de sua conversão em discurso e sobre o manejo da língua como atividade de pensar e de raciocinar, o que implica que nos deslocamos de uma visada linguística puramente cognoscente e buscamos olhar para o homem na linguagem, uma vez que "bem antes de servir para comunicar, a linguagem serve para viver" (Benveniste, 2006 [1966], p.222). No entanto, embora haja uma apropriação da língua e o seu manejo, as operações linguísticas envolvidas no processo de conversão da língua em discurso permanecem inconscientes. Por isso, é necessário compreender o que significa, nas teorizações de Benveniste, apropriar-se da língua e manejá-la. 
0 processo de apropriação da língua é um fenômeno que acontece quando um falante assume o lugar de locutor e (se) enuncia. Tratase do processo a partir do qual o locutor torna a língua apta a um uso específico. Já o manejo tem a ver com o intentado da significação e é relativo ao modo como o locutor mobiliza a língua para veicular sentido. 0 manejo da língua está, por conseguinte, submetido às leis que regem a sintagmatização e ao semantismo social que determina as associações possíveis. Na escrita acadêmica, o manejo da língua também está submetido à mobilização da teoria. A teoria (inter)fere (n)o manejo da língua e, por decorrência, (n)a sintagmatização.

O manejo da língua, portanto, é possível quando o falante, no lugar de locutor, é significado na e pela linguagem. Assim, o manejo da língua, sob a ordem própria da língua (escrita) e de suas possibilidades sintagmáticas e associativas, mostra a capacidade humana de pensar e de raciocinar. No caso da escrita acadêmica, o sujeito, ao tornar a língua escrita apta a um uso específico, mobiliza a teoria e a maneja de modo a inscrever-se nela. No espaço acadêmico, em situação de prova, essa escrita deve mostrar não só a compreensão das teorias, mas também seu posicionamento quanto a essas teorias, de forma que aconteça a mobilização teórica requerida pelo professor.

A mobilização teórica, por sua vez, acontece quando o sujeito maneja a teoria de modo a explicar o fato linguístico e o professor (re) conhece ali a apropriação. Esse manejo, no entanto, somente se dá quando o sujeito se inscreve na teoria. A inscrição teórica pode ser descontínua. O sujeito precisa ser significado na e pela teoria, de modo que ela faça sentido para ele, a fim de entrar em suas redes associativas e, assim se dando, haver a possibilidade de seu manejo, de modo que sua capacidade de pensar e raciocinar se mostre em sua escrita-resposta.

0 exposto acima mostra que lançamos nosso olhar para uma das "formas complexas do discurso" (Benveniste, 2006 [1970], p.90), a enunciação escrita, que "se situa em dois planos: o que escreve se enuncia ao escrever e, no interior de sua escrita, ele faz os indivíduos se enunciarem" (Benveniste, 2006 [1970], p.90). Pensemos no quanto esses planos da enunciação escrita se complexificam na escrita acadêmica que é, sobremaneira, marcada pela relação com os pares, haja vista a necessidade constitutiva de filiar-se teoricamente e de marcar uma diferença que a singularize. 
Nesse sentido, a escrita acadêmica ganha especificidades que lhe fazem funcionar na contradição. Os discursos que circulam no espaço acadêmico e as exigências impostas por ele levam-nos a entender que há um funcionamento contraditório da escrita nesse espaço. Ou seja, a escrita ali precisa mostrar a inscrição do aluno nas teorizações vigentes, mas também precisa mostrar que não se trata de mera (re)produção. A partir disso, entendemos que, no espaço acadêmico, há uma relação (in)tensa entre língua escrita, escrita e teorização.

De nossa parte, propomos (re)pensar a escrita no espaço acadêmico a partir da teorização de Émile Benveniste sobre a apropriação da língua no processo de conversão da língua em discurso e sobre o manejo da língua como atividade de pensar e de raciocinar. Compreendemos a escrita como um sistema simbólico de alto grau de abstração que implica uma subjetivação do locutor scriptor cuja premissa é a inscrição daquele que escreve em seu dizer, de modo que, ao escrever, o scriptor diz de si e de sua relação com a língua escrita e com aquilo que diz ao escrever.

\section{Língua (escrita) e escrita (acadêmica)}

De acordo com Benveniste (2014), "vivemos na civilização do livro, do livro lido, do livro escrito, da leitura e da escrita. Nosso pensamento está, em qualquer nível, constantemente informado pela escrita" (Benveniste, 2014, p.127). Isso significa que estamos em contato constante com a escrita. Entretanto, toda a aquisição da escrita é complexa e "supõe uma série de abstrações" (Benveniste, 2014, p.130), em que não devemos entendê-la como uma mera transposição da língua falada.

Uma primeira grande abstração reside, assim, no fato de que a língua se torna uma realidade distinta. De fato, instintivamente, falamos quando temos necessidade ou vontade de falar, em determinadas circunstâncias para obter determinado resultado, com uma pessoa que tem determinada voz em determinada relação de idade, de amizade etc. Sempre há situações em que o locutor exerce seu falar. A abstração consiste, então, em se desvincular da riqueza "contextual" que, para o falante, é essencial. [...] Ele precisa falar de coisas fora das circunstâncias que fazem com que tenhamos necessidade de falar, já que, para ele, são realidades vivas. [...] Trata-se de uma língua que não é proferida nem aos colegas nem a seus pais, uma língua que não sabemos nem quem fala nem quem escuta (Benveniste, 2014, p.130). 
Tornar inteligível a linguagem interior é uma operação de conversão que acompanha a elaboração da fala e a aquisição da escrita. Em "Dernières Leçons", Benveniste aborda a assunção à enunciação escrita. Para tanto, ele distingue a língua escrita da escrita. A língua escrita está para o modo semiótico; "é língua sob a forma escrita" (Benveniste, 2014, p.128). Já a escrita está para o modo semântico; não é mais somente língua sob a forma escrita, porque (com)porta a escrita de um sujeito.

A escrita, por conseguinte, (pres)supõe o estabelecimento de uma configuração enunciativa, a fim de que a relação discursiva se efetive. A escrita é endereçada a um co-locutor virtual que é projetado no e pelo mo(vi)mento de escrita no processo que a constitui. Similar à enunciação falada, na qual se instaura um eu-tu-ele-aqui-agora; na escrita instaurase um eu-tu-ele-não aqui-não agora. Esse não aqui e não agora permite um retorno ao escrito de modo que é possível realizar um trabalho elaboral sobre ele. 0 escrito é para um alhures ao mo(vi)mento de sua (re) produção. Isso implica uma necessidade outra de elaboração textual das coordenadas referenciais de pessoa(s), tempo e espaço.

De acordo com Benveniste (2014), na escrita, a língua se converte, de súbito, em imagem de língua. 0 ato de escrever não procede da oralidade, mas da linguagem interior. A escrita é uma transposição da linguagem interior; é necessário, de início, ascender a essa linguagem para assimilar o mecanismo de conversão em escrita. Benveniste caracteriza a linguagem interior como global, esquemática, não construída, não gramatical, alusiva, rápida, incoerente e, por vezes, associativa. Ela precisa ser transposta a uma forma inteligível para outros.

No caso de provas, por exemplo, é necessário que a teoria a ser mobilizada na explicação do fato linguístico já faça parte, de algum modo, da linguagem interior do aluno que escreve a resposta à questão da prova. Para tanto, é preciso que a teoria lhe toque e lhe faça sentido, de modo que ela entre em sua cadeia de significantes, fazendo, por conseguinte, parte de seu repertório. É fazendo sentido ao estudante que ele poderá apropriarse dela de modo a adaptá-la ao uso específico que é a sua resposta à questão da prova. Por mais parecidas que as respostas à questão possam ser, a sua escrita é singular, porque ela (com)porta a linguagem interior daquele que a escreve.

No mo(vi)mento de planificação do escrito, o aluno terá que organizar sua linguagem interior de modo a convertê-la em dizer e sintagma- 
tizá-lo. Esse processo duplo de planificação promove as diferenças entre as respostas e ela está marcada na seleção das palavras, no manejo dos conceitos, na articulação entre teoria e fato a ser analisado, assim como na conexão das frases. Por isso, por mais parecidas que as respostas possam ser, elas guardam algo de singular.

Análise. As provas (a)provam a escrita acadêmica?

Para analisar a assunção à escrita acadêmica em provas e sua descontinuidade em função da relação com o saber, valemo-nos de alguns exemplares de manifestação da linguagem provenientes de provas de graduação e provas de pós-graduação e da resposta escrita pelo aluno. No caso abaixo, trata-se de uma prova da disciplina Estudos da significação: semântica e pragmática, de um curso de Graduação em Letras, de uma Universidade Pública, aplicada em 2010, para uma turma de quinto período, o que significa que os alunos em fase da referida disciplina já haviam cursado quatro semestres letivos. Como esse curso contempla três semestres de núcleo básico, trata-se de alunos recém-ingressos no núcleo específico de Língua Portuguesa e Linguística. Utilizamos nas análises respostas de alunos em fase, ou seja, que não tiveram reprovação na disciplina.

\section{Exemplar (1):}

Questão 3: Com base no texto abaixo, discorra sobre a relação que existe entre significação e segmentação em unidades discretas.

\section{Verbos}

A professora pergunta para a Mariazinha:

_Mariazinha, me dê um exemplo de verbo.

_Bicicreta! - responde a menina.

_Não se diz "bicicreta", e sim "bicicleta". Além disso, bicicleta não é verbo.

Pedro, me diga você um verbo.

_Prástico! - disse o garoto.

_É "plástico", não "prástico". E também não é verbo. Laura, é sua vez: me dê um exemplo correto de verbo - pediu a professora.

_Hospedar! - respondeu Laura.

_Muito bem! - disse a professora. Agora, forme uma frase com este verbo. _Os pedar da bicicreta é de prástico! 
[Transcrição do texto disponível em <http://wwwl.uol.com.br/criancas/ piadas/ud98u.shl>. Acesso em 28 nov. 2005]

Resposta da aluna Cláudia ${ }^{1}$.

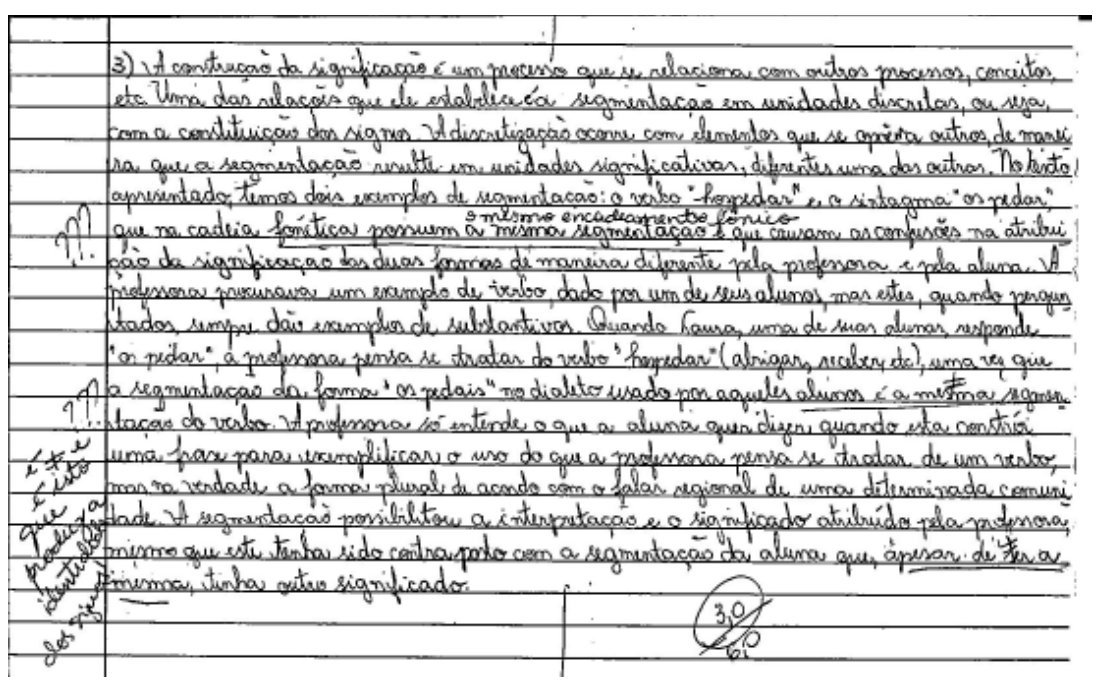

A resposta de Cláudia mostra que ela mantém em seu escrito uma confusão entre encadeamento fônico e segmentação, o que compromete a construção adequada de sua resposta. Assim, Cláudia perde pontos na correção, embora sua resposta demonstre que ela compreendeu o fato linguístico a ser analisado. No entanto, o manejo da teoria e dos conceitos mostram-se fragilizados. Como o locutor é quem corta a cadeia fônica, de modo a segmentá-la em unidades linguísticas, no texto a ser analisado, os cortes realizados pela aluna e pela professora na cadeia fônica /ospedar/ são diferentes e, por isso, há a atribuição diferente de significação e de identidade às formas linguísticas. "Hospedar" é uma palavra e "os pedar" é um sintagma nominal formado por duas formas linguísticas, embora apresentem a "mesma" cadeia fônica.

A confusão de Cláudia permite (entre)ver que a teoria estudada em aula ainda não se planificou em suas redes relacionais de associação de modo que ela possa se apropriar dela. Ela não encontrou um lugar naquilo que lhe faz sentido e, por isso, sua mobilização exorbita os bordos da teoria, sendo

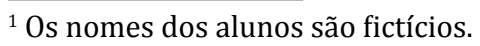


invadida pela oscilação terminológica e por recurso a termos conceituais advindos de outras teorias como o termo fonética em "cadeia fonética".

O Exemplar (2) também é extraído de uma prova aplicada, em 2012, na disciplina Estudos da significação: semântica e pragmática, em um Curso de Graduação em Letras, de uma Universidade Pública. As condições sociais são, portanto, similares às do exemplar (1). Trata-se, no entanto, de outra aluna, aqui nomeada Olívia.

\section{Exemplar (2):}

Questão 2) Analise o diálogo abaixo, utilizando os três valores do signo linguístico propostos por Mari (2008).

(contexto: casal, na cama, conversando após o sexo)

Mulher: - Queria que você conhecesse meus pais.

Homem: - Legal!...você tem uma foto aí.

Questão 5) Explique. Qual relação semântica está ocorrendo no enunciado abaixo?

Quando a namorada disse para o rapaz que estava cheia dele, ele perguntou: - E para quando é?

Respostas da aluna Olívia:

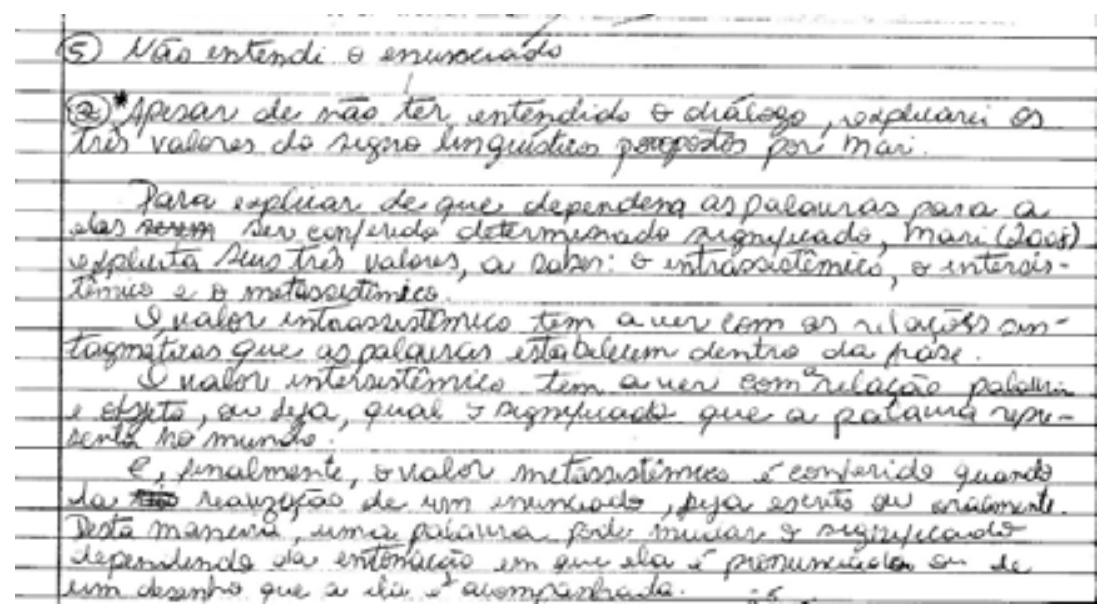

Diferentemente do que aconteceu com Cláudia naquele mo(vi) mento de escrita da resposta recortada no exemplar (1), Olívia não 
compreende o fato linguístico a ser analisado. Como não compreende o fato linguístico, ela não consegue responder à questão 5 . A questão 5 chega à Olívia como uma espécie de barulho, ou seja, não se constitui como um dizer para ela, o que não lhe permite nem manejar a teoria estudada em aula, uma vez que ela, ao não compreender o fato linguístico, não tem como nomeá-lo e, por isso, não tem como localizar em seu repertório os conceitos que poderiam lhe ajudar a explicá-lo. Como em relação à questão 5 , a concepção de uma resposta depende da compreensão do fato linguístico presente na manifestação de linguagem a ser analisada, Olívia encontra-se impossibilitada, naquele mo(vi)mento de enunciação, de colocar-se, permanece imobilizada no não-dizer que a incompreensão lhe provoca.

Em relação à questão 2, algo similar acontece. Olívia de novo não compreende o fato linguístico a ser explorado na produção da resposta e, por isso, não consegue explicá-lo a partir da mobilização da teoria posta na questão. No entanto, ela demonstra que compreendeu a teoria estudada em aula. Como a explicação da teoria não depende, nesse caso, da compreensão do fato linguístico, Olívia consegue explanála de modo adequado, mas não consegue, naquele mo(vi)mento de enunciação, manejá-la em função de uma análise. Portanto, embora tenha compreendido a teoria, ou seja, essa tenha chegado a ela como um dizer, ela, por não ter compreendido o diálogo a ser analisado, não possibilita ao professor reconhecer se ela seria ou não capaz de manejá-la na análise de um outro fato linguístico por ela compreendido.

O exemplar (3), por sua vez, é extraído de uma prova aplicada, em 2013, na disciplina, de caráter optativo, Semântica Argumentativa, de um Curso de Graduação em Letras, de uma Universidade Pública. Enquanto os exemplares (1) e (2) são relativos a uma disciplina do quinto período, o exemplar (3) é relativo ao último período do curso. Trata-se de uma disciplina optativa ofertada para alunos em situação de "possível formando". O Exemplar (3) traz um escrito da aluna Olívia, a mesma do exemplar (2). Vejamos, por conseguinte, outro mo(vi)mento de enunciação de Olívia, agora na condição de formanda.

Exemplar (3):

Questão 3) Analise o funcionamento dos operadores argumentativos presentes no texto abaixo de modo a avaliar a direção dos sentidos do texto 
e sua adequada ou não construção argumentativa. Mobilize na construção de sua análise uma escala argumentativa e, se necessário, reformule o texto. A televisão é um passatempo mortificante, pois, além de proporcionar às famílias um pouco de distração, reduz-lhes o tempo que poderiam dedicar à conversa, que cada vez se torna mais rara entre pais e filhos. (Trecho de texto de aluno do ensino médio)

Resposta da aluna Olívia

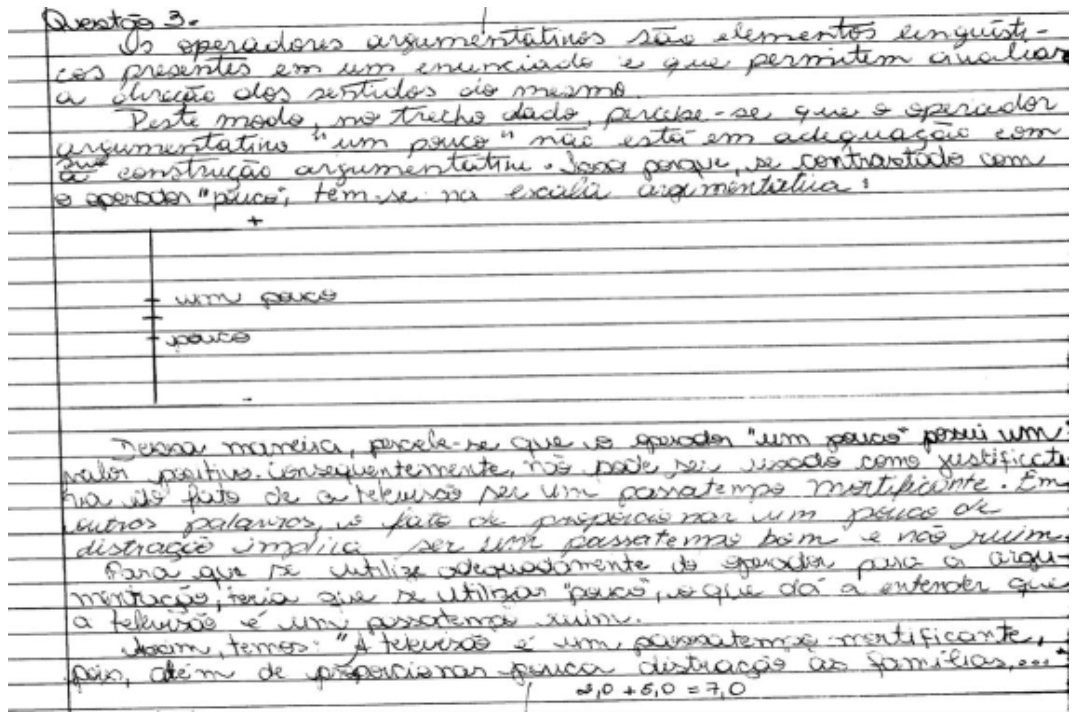

No exemplar (3), encontramos uma Olívia diferente daquela que aparece no exemplar (2). Em (3), ela compreende o fato a ser analisado assim como compreende a teoria a ser mobilizada na escrita da resposta, de modo que ela consegue colocar-se na resposta. Ela maneja a teoria de modo adequado e consegue empreender uma análise que explica o problema argumentativo do trecho do texto do aluno de ensino médio. Como ela encontra-se em outro mo(vi)mento de enunciação, é possível (entre)ver a descontinuidade de sua escrita acadêmica em funcionamento.

Não é possível atribuir essa diferença ao fato de Olívia estar no último período do curso. Mas é possível dizer que a teoria da argumentação na língua, em seu modelo das escalas argumentativas, constitui-se como uma teoria que lhe diz algo, que significa para ela e que, por isso, encontrou lugar em sua cadeia de significantes. Assim, ela consegue manejá-la e 
mobilizá-la na explicação de um fato linguístico. Acompanhar o percurso acadêmico de Olívia não deixa dúvidas de que o processo de assunção à escrita acadêmica é um processo descontínuo e em devir. É um processo que não se fecha, assim como é o processo de aprendizagem da escrita em geral. No entanto, na escrita acadêmica, naquilo que tange à mobilização conceitual de teorias, essa descontinuidade e devir são acirrados, porque (pres)supõem uma compreensão de outra ordem dos fenômenos e fatos a serem explicados, além de a teoria precisar encontrar lugar na cadeia de significantes que constitui aquele que escreve, a fim de assumir um lugar de valor de verdade em seu repertório de conhecimentos.

Os exemplares (4) e (5) são extraídos de provas aplicadas, em 2011, na disciplina Metodologia de pesquisa em Linguística e Linguística Aplicada de um Programa de Pós-Graduação em Estudos Linguísticos de uma Universidade Pública. Os dois exemplares são da aluna Rosa. 0 exemplar (4) refere-se a um recorte da primeira prova da disciplina e o exemplar (5) refere-se a um recorte do questionário respondido no primeiro dia de aula, a fim de traçar um perfil dos alunos.

\section{Exemplar (4):}

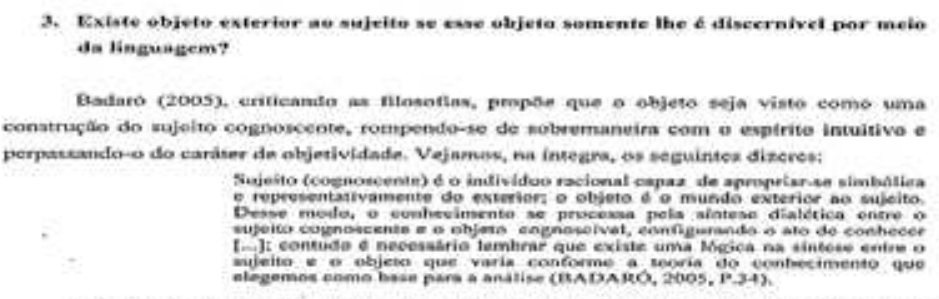

Tai posicionameno nos autoriza a concordar coun a posisao de Chaal c2009y. No dizer

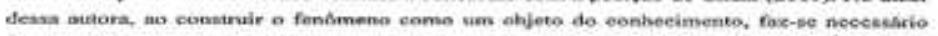
que ele seja controldvel, verifheavel, interprotivel a capas an sur retineade cu corriftido por

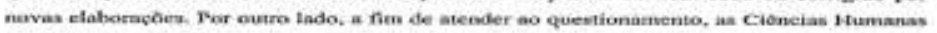

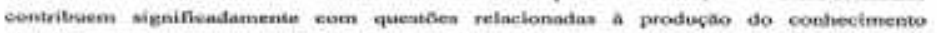

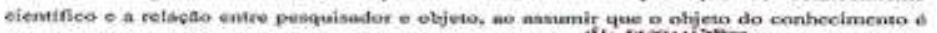

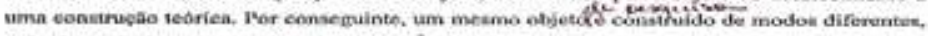

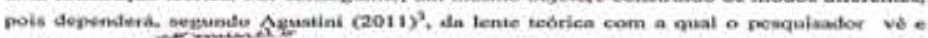

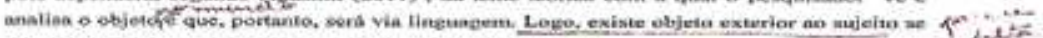
evise slyete nomente the do discemivel por melo da linguagem.

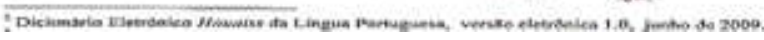

Embora Rosa tenha digitado as respostas da prova, alguns aspectos são interessantes de serem analisados: (1) Rosa vale-se de muitas citações, diretas e indiretas, em seu mo(vi)mento de escrita acadêmica. Embora seja uma prerrogativa da escrita acadêmica, as citações podem produzir certos 
efeitos sobre a escrita. Por exemplo, o efeito de existência de uma necessidade de caução forte, descortinando um receio em colocar-se de modo mais autônomo. Dizer dos teóricos para garantir um (suposto) acerto.

(2) A escrita de Rosa provoca/promove uma contradição. A direção argumentativa de seu escrito leva à conclusão de que não haveria objeto exterior ao sujeito, porque os objetos seriam indiscerníveis sem a linguagem. No entanto, ela escreve "Logo, existe objeto exterior ao sujeito se esse objeto somente lhe é discernível por meio da linguagem". Seria uma falha de digitação ou Rosa é "atropelada" em sua escrita por aquilo que diz dela?

Não é possível tomarmos uma decisão sobre o sentido do que seria esse esquecimento do "não", fazendo emergir a afirmação. Mas a relação de (1) e (2) habilita a hipótese de que a aluna Rosa estaria em contenda sobre o que tomar como valor de verdade. Nesse caso, a escrita de Rosa deixa flagrar traços de insegurança na mobilização teórica, uma vez que o manejo da teoria falha no processo de sua planificação, impelindo-a, inclusive, a citar os autores estudados em aula, de modo encadeá-los: Badaró (2005) é encadeado a Chauí (2009) que é, por sua vez, encadeada a Agustini (2011).

Podemos ainda (entre)ver uma certa incompreensão de Rosa sobre a questão do ponto de vista do observador, porque o esquecimento do "não" pode suscitar a hipótese de que Rosa tenha compreendido que o objeto no mundo não existe sem a linguagem, quando, com efeito, a questão é que, sem a linguagem, não é possível (re)conhecê-lo e, por isso, tomá-lo como objeto de pesquisa. 0 ponto de vista cria o objeto, porque o concebe de modo diferente. Nesse caso, a ausência das adjetivações do objeto pode constituir-se como um sinal dessa incompreensão, levandonos a questionar: de qual(is) objeto(s) fala Rosa?

O professor, de sua parte, tenta compreender Rosa e, para tanto, invade o escrito com suas próprias colocações, a fim de (re)direcioná-lo, segundo sua própria compreensão. No entanto, o professor deixa flagrar em seu apontamento a dúvida que o escrito de Rosa lhe suscita: "Parece que falta um "não"!" Assim, o professor tende a compreender que Rosa estaria co-referindo com ele e que, assim se dando, Rosa estaria compreende que o lugar do observador é fundamental na construção do objeto no mundo e, em decorrência, do objeto de pesquisa. Essa tendência impele o professor a marcar a resposta com um "ok". 
Contudo, a escrita de Rosa, nesse mo(vi)mento de enunciação, não permite que o professor tenha certeza do que Rosa compreende(u) daquilo que fora discutido em aula sobre a constituição do objeto de pesquisa e a importância do ponto de vista do observador em sua constituição. Trata-se de uma escrita muito agarrada ao dizer de outros, o que compromete a avaliação do professor. No exemplar (5), abaixo, essa relação acirrada com o dizer de outros expurga Rosa da resposta, o que se torna algo problemático, uma vez que o professor demandava dos alunos seu posicionamento. Vejamos:

Exemplar (5):

Questão 3) Para você, o que é língua?

Questão 4) Para você, o que é linguagem?

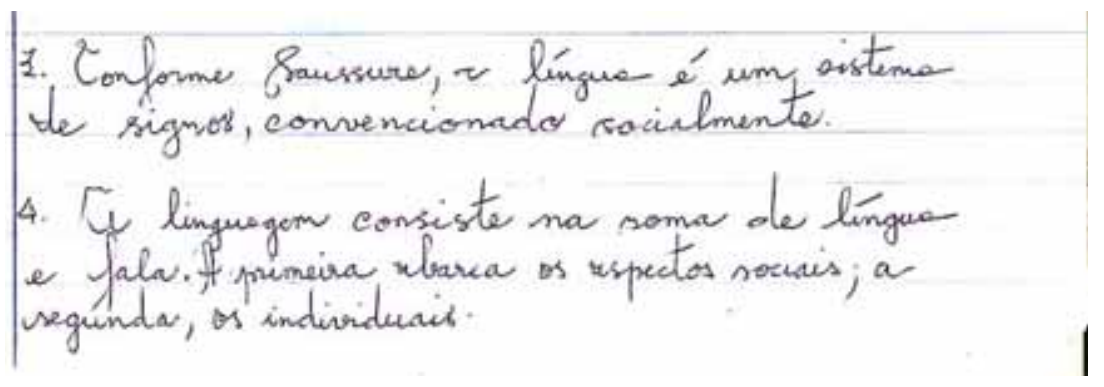

0 que encontramos no exemplar (5) é uma mobilização teórica que responde às questões feitas pelo professor, mas que silencia o "Para você" que inicia as perguntas a serem respondidas. Assim procedendo, ao contrário da solicitação feita pelo professor, Rosa não se posiciona teoricamente. Na questão 3, Rosa cita, ainda que de modo parafraseado, o que Saussure define como língua. Ela embasa sua resposta em Saussure e, ao fazê-lo, expõe seu escrito ao equívoco. Em seu escrito, "conforme Saussure" pode significar: (1) uma filiação teórica, assumindo valor de "assim como para Saussure, para mim, língua é..."; (2) uma colagem, assumindo valor de "para Saussure, língua é...; já para mim..."

Suponhamos que a compreensão do escrito de Rosa recaia em (1). Rosa vale-se de um argumento de autoridade: "conforme Saussure", cujo efeito é de filiação. No entanto, mesmo assim o equívoco permanece. Afinal, esse argumento é autoridade para ela ou para a comunidade acadêmica, ali representada pelo professor? Nesse sentido, trata-se de uma filiação de Rosa ou do professor (comunidade acadêmica)? 
Entretanto, se supormos que a compreensão do escrito de Rosa recaia em (2), a aluna vale-se de um argumento de autoridade para a comunidade acadêmica, ali representada pelo professor; mas o efeito é de que ela não assume esse conceito de língua como valor de verdade. Assim sendo, esse conceito de língua não faria parte de seu repertório; ele permaneceria como um aerólito, uma coisa a significar. E, por isso, ela não conseguiria manejá-lo de modo a apropriar-se dele em sua resposta escrita, subjetivando-se nele e por ele.

Na questão 4, ainda que Rosa não marque linguisticamente, como o fez na questão 3, ela mantém seu embasamento em Saussure, (re) escrevendo a operação matemática sassuriana presente no Cours de Linguistique Générale: língua = linguagem - fala. Há um mo(vi)mento enunciativo de manejar as variáveis da operação saussuriana. Ela mobiliza seus conhecimentos matemáticos e isola a variável linguagem, para obter o que ela é, deste ponto de vista saussuriano. Nesse sentido, linguagem (com)porta língua e fala. É no encontro entre língua e fala que a linguagem se dá. A resposta 4, embora sucinta, deixa flagrar algo de Rosa em seu escrito. Mas o que Rosa compreende por língua e por fala permanece na ordem do impossível nessa resposta. Seria o mesmo que para Saussure? Em caso afirmativo, em qual mo(vi)mento de sua elaboração teórica estaria ancorada a compreensão de Rosa?

Assim, Rosa deixa flagrar em sua resposta o que chamamos de descontinuidade na relação locutor-scriptor com os saberes que precisava mobilizar para responder as questões 3 e 4 . 0 que nos parece é que as teorias linguísticas sobre língua e linguagem estão para Rosa, no momento em que escreve sua resposta, na ordem do "barulho", do incompreensível e por isso a necessidade em re-dizer a partir de uma filiação teórica fortemente marcada, o que não permite, por sua vez, entrevermos que essas teorias a teriam tocado de modo a permitir-lhe não só apropriar-se da língua escrita em uma escrita, mas também manejá-las de modo a se inscrever nas teorias mobilizadas, produzindo não só uma cópia dessas teorias, mas um posicionamento quanto a elas.

Por cópia compreendemos a escrita tal qual a escrita presente no teórico citado, sem que o aluno produza sobre ela um posicionamento teórico ou um movimento de explanação de sua compreensão da citação, de modo a significar essa teoria para si e, assim acontecendo, ser capaz de analisar um fato linguístico a partir dela. A cópia, então, estaria para 
a ordem da língua escrita, em que há o reconhecimento do código e da teoria, mas não há propriamente um trabalho sobre estes. Assim, quando Rosa copia a definição saussuriana de língua, ela não nos permite entrever em seu escrito um posicionamento sobre essa teoria, mas apenas a citação de um conceito consagrado na Linguística, o que não é o esperado como resposta à questão, uma vez que a questão solicita o posicionamento do aluno. 0 que teria impelido Rosa a esse mo(vi)mento de cópia?

Várias são as respostas que podemos supor para esse mo(vi) mento. Podemos pensar que Rosa estava insegura, por ser o primeiro dia de aula ou mesmo por não estar convencida do que seria língua para ela. Poderíamos pensar também que ela, embora encontre na teoria saussuriana um aporte teórico, não se sente pronta para explicar o seu pensamento com propriedade. É possível também que Rosa tenha respondido assim porque sua experiência de linguagem estaria marcada por uma relação professoral de re-dizer os mestres.

\section{Considerações finais}

Como o objetivo desse trabalho era problematizar o processo de assunção do aluno à escrita acadêmica, a partir de um olhar sobre a sua relação com diferentes saberes acadêmicos com os quais ele tem contanto-confronto e que tem que mobilizar para atender às demandas de escrita que lhe são postas durante sua vivência acadêmica, buscamos (re)pensar a escrita no espaço acadêmico a partir das teorizações de Émile Benveniste sobre a apropriação da língua no processo de conversão da língua em discurso e sobre o manejo da língua como atividade de pensar e de raciocinar.

Buscamos empreender um mo(vi)mento teórico a partir da análise de textos produzidos por três alunas (duas de graduação e uma de pós-graduação), em que pudemos entrever a descontinuidade no manejo da teoria que há na escrita acadêmica, uma vez que essa depende não só da compreensão das teorias estudadas, mas da mobilização dessas teorias de forma que o aluno seja capaz de dizer algo a partir delas que não seja uma mera reprodução dos autores estudados. Além disso, a relação (in)tensa que há na escrita acadêmica é (re)velada pelas descontinuidades que aparecem no processo de assunção de um aluno à essa escrita institucionalizada.

Cláudia, por exemplo, mostra que sua relação com as teorizações que deve mobilizar para responder ao professor está fragilizada, mas 
ainda assim a aluna busca fazer a análise do fato linguístico através das teorias indicadas pelo professor, ainda que a fragilidade na apropriação destas afete sua resposta. Já Olívia, nas três situações analisadas, mostra a descontinuidade quanto a apropriação e manejo das teorias, tanto que em uma das questões a teoria para ela se apresenta de tal forma como um "barulho" incompreensível que ela não consegue sequer dizer algo sobre essa teoria e/ou sobre o fato linguístico a ser analisado.

Essa mesma descontinuidade pode ser observada com os exemplos analisados da aluna Rosa, em que a filiação teórica não se mostra consolidada a ponto de aluna deixar flagrar em seu escrito o dizer dos teóricos de modo marcado, o que conferiria ao seu escrito autoridade e acaba isentando-a de marcar um posicionamento seu quanto a essas teorias, já que a referência a autores consagrados na Linguística pode(ria) deixar subentendida a sua filiação teórica as teorias.

Dessa forma, a escrita acadêmica, de nossa perspectiva, não está para uma mera reprodução das teorias vigentes, já que é necessário haver o acirramento da relação entre língua escrita, escrita e teorização. Isso quer dizer que não basta que o aluno reproduza as teorizações que estuda em suas respostas; é necessário que o aluno signifique essas teorizações e seja capaz de mobilizá-las para atender a demanda do professor e da academia, já que essa escrita (pres)supõe um público-interlocutor específico. Os exemplares por nós analisados demonstraram que essa escrita ocorre de uma forma (in)tensa, dadas as suas especificidades e a necessidade de o aluno da graduação e/ou pós-graduação marcar um posicionamento teórico que não seja a mera reprodução das teorizações vigentes.

\section{Referências}

BENVENISTE, E. Problemas de linguística geral I. Tradução de Maria da Glória Novak e Maria Luisa Neri: revisão do prof. Isaac Nicolau Salum. 5ed. Campinas, SP: Pontes Editores, 2005. Tradução de: Problèmes de Linguistique Générale.

. Problemas de linguística geral II. Tradução de Eduardo Guimarães et al. 2ed. Campinas, SP: Pontes Editores, 2006. Tradução de: Problèmes de Linguistique Générale II.

. Últimas aulas no Collège de France (1968 e 1969). Tradução de Daniel Costa da Silva et al. São Paulo: Unesp, 2014. Tradução de: Dernières leçons: Collège de France (1969 e 1969). 


\section{O laço na escrita em textos acadêmicos: um estudo enunciativo}

Jorama de Quadros Stein

Marlene Teixeira

\section{Palavras iniciais}

Esta reflexão decorre do trabalho apresentado no IV Simpósio Internacional de Ensino de Língua Portuguesa - Sielp, ${ }^{1}$ no Grupo de Trabalho - GT A escritura acadêmica no processo de assunção ao discurso acadêmico. Partimos da preocupação em estudar o processo de escrita em textos acadêmicos com foco na configuração do laço entre professorrevisor e aluno-scriptor. ${ }^{2}$ Convidamos o leitor a buscar em Benveniste formulações essenciais para pensar sobre a escrita de forma a concebê-la como indissociável da relação entre aquele que escreve e aquele que lê ou revisa o texto.

${ }^{1}$ O GT foi coordenado pela Profa. Dra. Carmen Agustini (UFU) e pelo Prof. Dr. Ernesto Bertoldo (UFU), em Uberlândia-MG. A eles, eu, Jorama de Quadros Stein, agradeço pela acolhida, pela partilha e pelo convite para trazer para a escrita uma reflexão a partir da comunicação oral realizada. À minha orientadora, toda a minha gratidão pela interlocução ofertada para a qualificação deste estudo e por fazer comigo um laço muito além do âmbito acadêmico, um laço que ressignifica a forma com que olho para mim, para esta escrita e para minha prática como professora.

${ }^{2}$ Scriptor, para nós, designa aquele que escreve, que se diferencia do autor. É a tradução do termo scripteur, utilizado por geneticistas do texto como Irène Fenoglio (2011). 
Para elucidarmos as formulações que nos permitem pensar na escrita por/com/em Benveniste, partimos de alguns princípios básicos: a) o homem está na língua; b) o sujeito é um ponto de chegada; c) sem tu não há eu; d) a escrita é a cada vez uma re $e^{3}$-invenção. Os pontos, por ora somente elencados, serão discutidos a seguir e mais adiante sustentados através da apresentação de uma resenha acadêmica, produzida em duas versões, a qual integra o corpus de textos que constitui o material de investigação da tese da qual parte este estudo. ${ }^{4}$

\section{O sujeito aos pés de um tu}

O sujeito, durante algum tempo, foi excluído dos estudos linguísticos. Tratar do sujeito era ter de enfrentar a "cabeça de medusa", para utilizar a expressão de Benveniste para se referir ao estudo do sentido. Deixávamos para a filosofia e para a psicologia essa preocupação e nós, da linguística, nos dedicávamos a estudar a linguagem dissociada do sujeito, porém, com o tempo, irremediavelmente, o sujeito clamou por espaço em nossas pesquisas. Afinal de contas, se há linguagem, há um locutor que se instaura nela e que se implica subjetivamente em seu dizer.

Charles Bally, linguista francês, que se dedicou ao estudo da língua e da literatura clássica, começou a se perguntar sobre a subjetividade na linguagem. Mais tarde, Benveniste, linguista sírio, naturalizado francês, que se dedicou ao estudo aprofundado de diversas línguas e, ao mesmo tempo, ao desenvolvimento de uma teoria enunciativa da linguagem, continuaria a problematizar essa questão por tratar homem e língua(gem) como indissociáveis. Nesse contexto, Benveniste sustentou, como bem sabemos, que a intersubjetividade é condição para a subjetividade, pensamento sintetizado, a priori, no texto Da subjetividade na linguagem, de 1958

\footnotetext{
${ }^{3}$ Separamos o prefixo -re do restante da palavra para assumirmos, em nosso relato, a perspectiva benvenistiana, uma vez que para Benveniste (2005d, p.26), “a linguagem reproduz a realidade. Isso deve entender-se da maneira mais literal: a realidade é produzida novamente por intermédio da linguagem". 0 re, em itálico no original em francês, enaltece a crença que perpassa as formulações de Benveniste ao longo de seus textos: o novo a cada enunciação, isto é, neste caso, a linguagem produz sempre de maneira nova a realidade.

${ }^{4}$ Usamos "da tese da qual parte este estudo" para definirmos que nos referimos à parte do corpus da tese em curso de Jorama Stein, uma das autoras deste trabalho. A co-autora, como orientadora, contribui com apontamentos e reflexões fundamentais para a discussão aqui proposta.
} 
(2005b), e que se constitui em uma premissa para compreender duas coisas no autor: que só há enunciação mediante um tu, postulado como alocutário, e que é somente a partir deste tu que é possível observarmos o sujeito.

Logo, compreender o sujeito na teoria da enunciação é fundamental. Normand (2009) salienta a flutuação do termo em Benveniste. A expressão aparece grafada de diversas maneiras, como em itálico ou entre aspas e às vezes como sinônimo de locutor ou indivíduo. A linguista esclarece, ainda, que é preciso compreender que o sintagma sujeito do enunciado e sujeito da enunciação não aparece em Benveniste.

Flores (2013) explica que o sujeito da enunciação é o que advém da sintaxe da enunciação e sua existência está ligada ao fato de atribuirmos ao conjunto das formulações de Benveniste o estatuto de linguística da enunciação. Dessons (2006), por sua vez, assegura que a noção de discurso preencheu, de certa forma, a falta do sujeito. É um ponto bem importante, afinal de contas, o discurso pressupõe uma atividade de linguagem do homem.

Instaurou-se, aos poucos, uma linguística que não pode deixar o homem de lado porque faz ciência sobre um homem que está sempre se enunciando. 0 locutor, que, contudo, se instaura na linguagem, não é o sujeito. 0 sujeito advém do que foi dito, mas não do que está estanque no enunciado. Advém dos encadeamentos, da enunciação em si. Advém não somente dos índices específicos, mas também dos procedimentos acessórios $^{5}$. Só que não podemos apreendê-lo em sua totalidade e, por isso, cabe a nós buscar a compreensão dos agenciamentos sintagmáticos para saber qual sujeito emerge de cada instância de enunciação.

Por isso Capt (2013) tem muita razão ao distanciar o sujeito da enunciação das concepções metafísicas. 0 linguista francês mostra que o sujeito da psicologia e de vertentes pragmático-comunicacionais da linguística nada tem a ver com o sujeito benvenistiano, pois o último é um "ponto de chegada" (Capt, 2013, p.82) e não um ponto de partida. Ele assegura a transitividade, a incompletude e a dependência do sujeito do linguista sírio: "Assim considerado, o sujeito é transitivo, sempre sujeito 'de alguma coisa'. Ele não é autossuficiente. Ele não é autônomo. Ele é incompleto. Ele depende do outro" (Capt, 2013, p.78, tradução nossa).

\footnotetext{
${ }^{5}$ Para uma compreensão do jogo entre índices específicos e procedimentos acessórios na análise enunciativa benvenistiana, conferir: ARESI, F. Os índices específicos e os procedimentos acessórios da enunciação. ReVEL, v.9, n.16, 2011.
} 
Trata-se, portanto, de um sujeito que não emerge se não houver um outro que o autorize a ser sujeito. Só nos tornamos sujeitos ao falar porque somos reconhecidos como tal ao fazê-lo: “o sujeito que nós conservamos na linguagem possui uma descontinuidade permanente, uma historicidade radical, uma plasticidade constitutiva. Um sujeito em constante recomeço, um sujeito aos pés de um 'tu'”' (Capt, 2013, p.79, tradução nossa).

Quando problematizamos a escrita, uma complexidade se instaura, pois, precisamos pensar sobre o sujeito. 0 alocutário, postulado pelo scriptor, nem sempre é consciente e nem sempre pode estabelecer uma comunicação intersubjetiva de fato. E aí é preciso um olhar aguçado sobre os encadeamentos, sobre as escolhas daquele que escreve para que percebamos que sentidos emergem e qual sujeito advém.

Ao observarmos as diferentes versões de um texto, com as interferências da revisão do professor, podemos investigar os sentidos que se reestabelecem e é aí que podemos fazer uma linguística atenta ao homem que se renova a cada vez que se enuncia. Para tanto, é bem importante a experiência de atentarmos para a escrita se materializando, se fabricando, a exemplo dos trabalhos que são objetos de estudo da linguista geneticista Irène Fenoglio.

Não queremos com isso excluir a relevância do estudo da versão final do texto. Queremos ver, no processo, uma alavanca propulsora para compreender mais e melhor os sentidos e o sujeito de uma escrita. E mais: encaramos o professor como um problematizador que, ao realizar uma revisão que configure troca no processo, possa de fato auxiliar os seus alunos a deslocar o endereçamento de seus textos para outros leitores. Para isso, é preciso discutir mais sobre o sentido na escrita, pois é mais uma chave para o trabalho com o texto.

\section{Sentido na enunciação}

Para tratarmos do sentido em Benveniste com enfoque na escrita, é preciso atentar para o que o linguista sugere ao final do artigo $O$ aparelho formal da enunciação (Benveniste, 2006c), no qual ele abre a possibilidade de estudarmos as formas complexas do discurso:

Será preciso também distinguir a enunciação falada da escrita. Esta se situa em dois planos: o que escreve se enuncia ao escrever e, no interior de sua 
escrita, ele faz os indivíduos se enunciarem. Amplas perspectivas se abrem para a análise das formas complexas do discurso, a partir do quadro formal esboçado até aqui(Benveniste, 2006c, p.90, grifos nossos).

Anteriormente, no final de Semiologia da língua (Benveniste, 2006d), o autor propõe que ultrapassemos a noção saussuriana de signo e que o façamos de duas maneiras: por uma análise intralinguística ou por uma análise translinguística. A última é que nos permite investigar textos e obras e pressupõe a elaboração de uma metassemântica que se constituirá sobre a semântica da enunciação.

Flores e Teixeira (2013) tratam sobre essa proposição benvenistiana de estudarmos as formas complexas do discurso e explicam a amplitude desse convite: fazer uma linguística que olhe para os textos, as obras, a arte. Eles salientam que Benveniste não chegou a evidenciar a maneira de concretizar a segunda via da semiologia, embora suas formulações tragam subsídios para tal. Os autores acentuam a relevância da problematização da escrita em Dernières Leçons (Benveniste, 2012) como um passo do linguista sírio na abordagem dessas formas.

A escrita para Benveniste é, portanto, uma forma complexa do discurso que, como ele mesmo formulava na obra publicada em 2012, pressupõe uma série de abstrações e toma um dimensionamento que a afasta de mera representação da fala. Da lição 8 até a 15, temos um Benveniste professor, como bem lembram Agustini et al (2013). Trata-se de um professor que discute o semiótico e o semântico partindo do estudo de diferentes línguas a fim de problematizar o lugar da escrita entre os sistemas.

É nessa publicação que Benveniste esclarece que, se a língua é dotada de dupla significância, a escrita é a prova disso. Logo, é quase impossível pensar sobre a escrita sem compreender bem como Benveniste concebe o semiótico e o semântico. Sabemos que muito se ouve acerca da significação desses termos. Por ora, e para os propósitos desta reflexão, sintetizamos o que nos parece mais caro no emprego dos termos em Benveniste: ambos são constituídos por forma e por sentido.

A preocupação de Benveniste é unir forma e sentido tanto no nível formal quanto no discurso. No semiótico, a forma é o significante e o sentido a capacidade de ser distinguido no sistema."Significar é ter um sentido, nada mais" (Benveniste, 2006a, p.277). Nesse nível, "ser distintivo e ser significativo é a mesma coisa” (Benveniste, 2006a, p.28). 
No semântico, a forma é constituída pela sintagmatização e o sentido pela referência coconstruída, pela ideia. 0 "mundo" é subjetivado na cultura. É um mundo construído pelo locutor que se apropria da língua e que é redimensionado pelo $t u$, na interlocução. Nesse sentido, é da vida da linguagem não ter condição de expressar o mundo tal como é porque entre o semiótico e o semântico há um locutor que se apropria da língua, mas que leva consigo os tantos outros nele implicados.

Flores (2013) elucida bem que,ao tratarmos do sentido em Benveniste, temos dois questionamentos para nortear nossos estudos. Quando consideramos o semiótico, o sentido está no nível da designação e, portanto, é preciso perguntar se há ou não há sentido, bem na acepção saussuriana do termo: uma coisa é aquilo que a outra não é. Isso Benveniste faz ao dar o exemplo: "Chapéu existe? Sim. Chaméu existe? Não" (Benveniste, 2006a, p.227). Já no semântico, a pergunta é: qual é o sentido? Ou seja:

A noção de semântica nos introduz no domínio da língua em emprego e ação; vemos desta vez na língua sua função mediadora entre o homem e o homem, entre o homem e o mundo [...] impondo a adesão, suscitando uma resposta[...] em resumo, organizando toda a vida dos homens (Benveniste, 2006a, p.229).

Mello (2012) sintetizabem a compreensão do sentido em Benveniste ao esclarecer que a frase, por ser particular, é um acontecimento que desaparece porque os sentidos se ressignificam a cada vez.

Benveniste propôs que pensássemos em uma semiologia de segunda geração para tratar da escrita, justamente pela sua distinção em relação à fala. Acreditamos, porém, que os subsídios para tal já estão nas formulações que ele realiza ao longo de seus estudos, questão que não será trazida neste texto, pois mereceria mais aprofundamento. Por ora, somente ressaltamos que a semiologia de Benveniste é baseada na enunciação e no discurso, por isso que é uma semiologia de segunda geração.

O que propomos é nos apropriarmos da proposta benvenistiana à medida que estudamos a configuração do laço no processo de escrita. Tratemos um pouco mais do laço. 
O laço no processo de escrita: uma chave metodológica

O sentido que emerge da escrita é sempre novo a cada versão de um texto. Essa afirmação corresponde à singularidade inerente a cada ato enunciativo, conforme a proposição de Benveniste. E só é possível pensarmos no sentido porque há um "homem na língua", que se instaura a cada vez que o locutor se propõe como eu e o faz sempre de maneira nova, como o próprio Benveniste constatou ao estudar diversas línguas.

Se única é a condição do homem na linguagem, essa singularidade deve ser cuidadosamente estudada ao tratarmos do processo de escrita. Encontramos, nas formulações de Benveniste, suporte para investigar cada uma das versões de um texto como um espaço singular de enunciação.

Já sabemos que o sentido que emerge diz do sujeito. Esse sujeito, a posteriori, nos obriga a lembrar que aquele que emerge na escrita pode não ser o mesmo que emerge na relação em sala de aula. Mas reconhecemos que uma relação de troca desencadeadora de aprendizagem no dia a dia das aulas pode contribuir para sustentar uma troca de fato na relação da escrita.

Se temos uma escrita em processo, temos uma relação nessa escrita a ser observada. A observação da existência ou não de troca nessa escrita tem seu ponto de partida no estudo dos pronomes em Benveniste, pois é somente a partir dos índices eu-tu que podemos tratar do laço na escrita. Acreditamos, como afirma Teixeira (2012), que no estudo dos pronomes em Benveniste há um projeto de uma ciência geral do homem: "tenho proposto o deslocamento da interpretação que a restringe ao estudo das marcas da subjetividade na linguagem no âmbito intralinguístico, na direção das atividades significantes dos homens em qualquer tipo de interação social" (Teixeira, 2012, p.72).

Em textos como A natureza dos pronomes, de 1956 (2005a) e Estrutura das relações de pessoa no verbo, de 1946 (2005c), Benveniste trilha um caminho de 10 anos, que faz com que estenda a discussão dos pronomes para além da categoria gramatical. Mostra a assimetria entre eu-tu-ele. Embora no primeiro artigo, o eu ganhe destaque explícito, no segundo $e u$-tu são problematizados como posições na linguagem.

É em Da Subjetividade na linguagem, de 1958, que fica mais evidente o caráter antropológico do estudo de Benveniste: “É um homem falando que encontramos no mundo, um homem falando com outro homem, e 
a linguagem ensina a própria definição do homem" (Benveniste, 2005b, p.285). E continua: "A consciência de si mesmo só é possível se experimentada por contraste. Eu não emprego eu a não ser dirigindo-me a alguém, que será na minha alocução um tu" (Benveniste, 2005b, p.286, grifos nossos).

A afirmação em destaque sustenta a leitura que Capt (2013) faz do sujeito em Benveniste como um ponto de chegada, sempre sujeito de algo e insuficiente a si mesmo. Esse sujeito só emerge porque há um tu. Sem o tu não há eu.

Dufour (2000) leva-nos a problematizar a instanciação do quadro figurativo aluno-scriptor e professor-revisor tomando a abordagem dos pronomes em Benveniste em uma dimensão mais antropológica:

Quando um sujeito fala, ele diz "eu" a um "tu" a propósito d" "ele". Falem e porão em jogo este sistema e, a partir de então, um fantástico ordenamento do discurso será instantaneamente efetuado. Poderei realmente dizer o que quiser [...] desde que eu enuncie para um "tu" (um leitor, também), meu discurso vai apresentar as garantias implicitamente requisitadas por todo interlocutor" (Dufour, 2000, p.69, grifos do autor).

Araújo (2014) evidencia que toda enunciação pressupõe endereçamento de um eu a um tu, mas que nem sempre ocorre a troca entre os interlocutores. Ela sustenta que o endereçamento diverge da alocução propriamente dita, em que um falante apenas se dirige ao outro. 0 endereçamento, de acordo com a autora, além de projetar os participantes dessa alocução, via representação, circunscreve a possibilidade de essa projeção não se efetivar de modo a converter a língua em discurso no ato de linguagem que o produz.

Nesse sentido, Rocha (2014), baseada na ideia que a intersubjetividade é condição para a comunicação intersubjetiva, sustenta que, se para haver comunicação intersubjetiva, é preciso troca, ela só é possível pelo tu, logo o laço, de que tratamos aqui, só acontece se houver troca.

Para Araújo (2014), o laço corresponde à relação dialógica em que o $e u$, ao se endereçar a um $t u$, implica-se subjetivamente. Para ela, é fundamental o estabelecimento do processo de correferenciação entre os interlocutores porque assim é produzido o efeito pragmático da troca. Nesse sentido, podemos dizer que comunicação intersubjetiva e laço não são conceitos que se recobrem, mas sim que o primeiro é ponto de partida para o segundo. 
Nós podemos afirmar, assim, que o laço pode ser fundamentado a partir da teoria dos pronomes e do conceito de intersubjetividade em Benveniste, mas jamais pode ser bem concebido se não tivermos clareza da concepção benvenistiana de sujeito. 0 laço em Benveniste pode ser melhor compreendido se tomarmos sua teoria em uma dimensão antropológica. Assim como o sujeito benvenistiano só é possível na e pela linguagem, o laço também é observável no/pelo processo de escrita. 0 laço tem, portanto, uma dimensão incapturável porque advém da experiência única entre o aluno-scriptor e o professor-revisor. 0 laço, tal como estudamos aqui, é dimensionado em um olhar sobre o processo de enunciação, logo é complexo de ser observado.

Vejamos o que diz A linguagem e a experiência humana (1965), um dos textos que mais tem sustentado reflexões para projetar os estudos de Benveniste para além da linguística:

Desde que o pronome eu aparece num enunciado, evocando - explicitamente ou não - o pronome tu para se opor conjuntamente a ele, uma experiência humana se instaura de novo e revela o instrumento lingüístico que a funda. Mede-se por aí a distância, ao mesmo tempo ínfima e imensa, entre o dado e sua função. Estes pronomes existem, consignados e ensinados nas gramáticas, ofertados como os outros signos e igualmente disponíveis. Quando alguém os pronuncia, este alguém os assume, e o pronome eu, de elemento de um paradigma, se transforma em uma designação única e produz, a cada vez, uma nova pessoa. Esta é a atualização de uma experiência essencial, que não se concebe possa faltar a uma língua (Benveniste, 2006b, p.69, grifos nossos).

Propomo-nos, portanto, a olhar para a escrita enquanto reveladora da experiência humana. Essa proposição nos exige um trabalho cuidadoso para o processo em que o eu se instaura diante de um tu. Esse texto de 1965 aborda a temporalidade linguística, fundada no discurso. Podemos dizer que há algo a ser transposto para o estudo da escrita: um outro sistema, que exige outra organização do homem à medida que ele se reposiciona em seu discurso e em que a intersubjetividade é reiterada como o estopim para a troca:

A intersubjetividade tem assim sua temporalidade, seus termos, suas dimensões. Por aí se reflete na língua a experiência de uma relação primor- 
dial, constante, indefinidamente reversível, entre o falante e seu parceiro. Em última análise, é sempre ao ato de fala no processo de troca que remete a experiência humana inscrita na linguagem (Benveniste, 2006b [1965], p.80, grifo do autor).

Consideramos que é no processo de troca na escrita que se instaura/ registra uma experiência humana e é somente quando analisamos todo o processo que é possível redimensionar junto ao aluno de tal forma a sua escrita a ponto de convidá-lo a re-inventar a sua relação com ela. É através da relevância que damos ao processo, que podemos ressignificar a compreensão da re-escrita na escola e na universidade.

É a partir de uma reflexão sobre o laço em uma dimensão antropológica da linguagem, que configuramos, ainda que, por ora, parcialmente, nossa metodologia de análise.

Trata-se de um corpus de 10 textos de alunos universitários de diferentes cursos (todos, com, no mínimo, duas versões). Desses, foram escolhidos dois, os quais sofreram uma interferência mais marcada da professora. No entanto, aqui, apresentamos o exemplo de um dos textos.

Há uma particularidade na análise do corpus de pesquisa: como observamos a singularidade de cada escrita, não tomamos esse conjunto de textos como um produto acabado. Filiamo-nos ao estudo de Nunes (2012) para olhar esses textos considerando a singularidade do locutor e a unicidade de cada ato enunciativo. Assim, com base em Benveniste, consideramos a impossibilidade de delimitar uma unidade de análise como a priori de nossa investigação justamente por não ser o enunciado em si, mas a enunciação o nosso objeto.

Nesse sentido, não utilizamos o material de análise para corroborar uma hipótese prévia porque isso iria na contramão de nosso entendimento a respeito de sujeito e de sentido em Benveniste. Nunes (2012) ressalta que o analista tem um corpus de dados, mas que ao decidir quais aspectos serão analisados, ele imprime um recorte. 0 recorte em nossa análise está na configuração do laço entre professor-revisor e aluno-scriptor.

De acordo com essa visão, neste estudo, delimitamos nosso enfoque em dois pontos: descrever os movimentos realizados pelo aluno a partir da interferência da professora conforme as categorias da crítica genética e discutir algumas implicações da observação desses movimentos para a compreensão do laço. 


\section{Um olhar para o processo de escrita}

O texto que apresentamos é composto por duas páginas em cada versão. Começamos apresentando a primeira página da primeira versão do texto analisado junto da primeira página da segunda versão. Em seguida, os movimentos realizados pela aluna são apresentados. Trata-se de um relato que evidencia o que o aluno faz a partir da interferência do professor em seu texto. Após, trazemos a segunda página de cada uma das versões em comparação uma com a outra. Esse registro constitui um dos primeiros passos para uma futura análise mais detalhada.

Athidade Acadbmica: Dxperimentacbio Textual - Hordrio 22 Aula de 18.11.2013: Claborando uma resenha academica

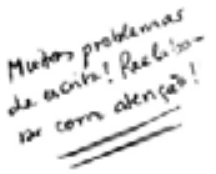
Bullying: prevalência, implicaçōes e diferenças entre os
gêneros.

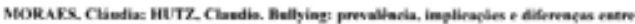

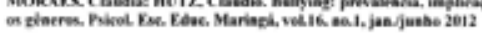

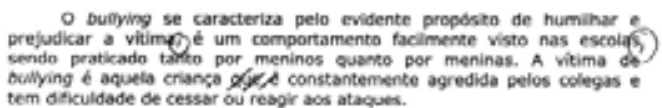

O artigo Bullying: prevalkncia, implicaçōes e diferenças entre os gèneros, de autoria da psicóloga Clbudia Moraes, doutoranda da UfRGS e do professor Claudio Hutz, thular do departamento de psicologia da UFRGS, for recentemente publicado pela revista Psicologia Escolar- Educacionai o estudo teve como objetivo levantar a ccorréncia do bullying jem crianças e adolescentes de escolas do munidipio de Porto Alegre (RS).

0 artige segue uma codem frotor

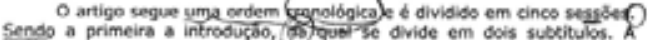
seguir, a segunda sesslo traz o método de pesquisa, tambem abordado em dois subticulos: os instrumentos e os procedimentos utilizados. Na terceira sessajo, $s 50$ trazidos es resultados da pesquisa, que salo demonstrados em

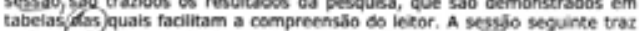
a discusckb dos resultados e na guine e útima sessabo, podemos ler as consideraçōes finais dos autorks.

Na introduclo do artigo, os autores usam referêneias bibliogrbificas fara lexplicar (Dardo jo kitor sobre o que se trata o bullying. No primeirs subtizulo a a

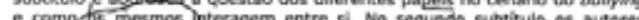
trazem an-diferencias entre os gêneros, no qual explicam os tipos de \& agressdes mais usadas por cada ghera. 7

Na proxima sesslo e explicado sozhe ò método de pesquisa utilizado.

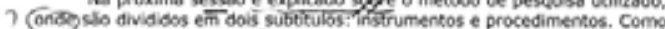
insfrumente de pespuisa? é euplicado gue os alunos utilizaram um questionirio; e sobre os procedimentos, e esclarecida aloumas questles comcardith

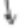
Concetor inade pusdo!

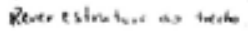

Versão 1- página1 
Atividade Académica: Experimentaçắo Textual - Horárlo 22 Aula de 18.11.2013: Elaborando uma resenha acadêmica

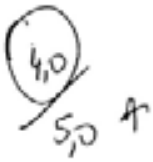

Bullying: prevalência, implicações e diferenças entre os gêneros.

MORAES, Claiedia; HITZ, Claudio, Bullying: prevaltacis, implicaş̋̃es e diferenças entr: es gtaeres. Pricel. Eas. Eilue. Mariezi, vol.16, no.1, jan-Juabs 2012

o bullying sefyaracteriza pelo evidente propósito de humilhar e prejudicar a vitimg um comportamento facilmente visto nas escolas, sendo praticado tornto por meninos quanto por meninas. A vitima de bullying é aquela criança constantemente agredida pelos colegas e tem dificuldade de cessar ou reagir aos ataques.

O artigo Bullying: prevalência, implicaçōes e diferenças entre os generos, de autoria da psicologa Cláudia Moraes, doutoranda da UFRGS e do professor Claudio Hutz, titular do departamento de psicologia da UFRGS. foi recentemente publicado pela revista Psicologia Escolar e Educacional. O estudo teve como objetivo levantar a ocorrênda do bullying em crianças e adolescentes de escolas do município de Porto Alegre (RS).

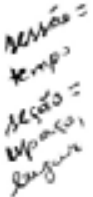

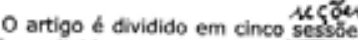

a qual se divide em dois subtitulos. A sendo a primeira a introdução, metodo de pesquisa, tambem aborda. A seguir, a segunda sessăo traz o metodo de pesquisa, também abordado em dois subtitulos: os instrumentos resultados da pesquisa, utilizados. Na terceira sess.5. são trazidos os resultados da pesquisa, que şo demonstrados em tabelas as quais facilitam a compreensåo do leitor. A sesg.jo seguinte traz a discussắo dos resultados e, na quinta e última sessăo, podemos ler as considerap̧̄es finais dos

Na introduçăo do artigo, os autores usam referèncias bibliogrdficas para explicar ao leitor o que seria o fenômena bullying. No primeiro subtitulo, é abordada a questảo dos diferentes pap 19 no cenário do bulllying e como esses interagem entre si. No segundo subtitulg os autores trazem as diferenças entre os gêneros, e explicam os tipos de agressōes mais usadas por cada gênero.

Na segunda sessăgé explicado o método de pesquisa utilizado. A sepe: é dividida em dois seboitulos: instrumentos pesquisa utilizado. instrumento de pesquisa, os alunos utilizaram um questionário; e sobre os procedimentos, săo esclarecidas algumas questöes sobre como os

Versão 1- página 2

Ao lermos atentamente a primeira página de cada uma das duas versões é possível perceber duas preocupações: a) seguir o padrão sugerido para a escrita do texto; e b) realizar as correções de ordem sintática e morfológica: termos, pontuação, estrutura das frases.

No primeiro parágrafo, é possível visualizar a solicitação da profes- 
sora Liane: ${ }^{6}$ adição de um ponto e vírgula e de uma vírgula e supressão de um pronome, alterações que foram atendidas pela aluna Sara. No segundo parágrafo, há a adição de uma vírgula e a colocação em itálico da expressão bullying, ambos os movimentos sugeridos pela professora.

No terceiro parágrafo, diante do ponto de interrogação assinalado pela professora, a aluna suprime o segmento "uma ordem cronológica", substituindo o ponto por uma vírgula. A primeira modificação incide sobre o sentido da oração e ainda fica a dúvida se a aluna entendeu o que de fato quer dizer a expressão "cronológica." A segunda auxilia somente no encadeamento da oração.

Nesse mesmo parágrafo, a palavra "sessão" é assinalada três vezes e mantida pela aluna na segunda versão, o que marca a dificuldade de saber o motivo de realizar tal modificação e, por isso, a professora aponta a diferença entre "seção" e "sessão" na margem esquerda da segunda versão. Há uma outra questão relevante: como a aluna entende o sentido da expressão "na qual" e "a qual"? Pois ela suprime o "n" apenas diante da solicitação da revisora. Assim também ela insere as vírgulas solicitadas, as quais intercalam o adjunto adverbial "na quinta e última sessão".

No quarto parágrafo, há a repetição da preposição "para", circulada na correção, o que a aluna resolve através da supressão da segunda ocorrência e a adição de "a" junto ao "o" formando "ao leitor". A professora solicita a colocação de duas vírgulas para indicar adjunto adverbial no início da oração. Marca um ponto de interrogação próximo da expressão "os mesmos" e outro perto de "no qual". O primeiro caso é solucionado por Sara com a substituição pelo pronome "esses". 0 segundo caso é descartado pela aluna e substituído pela conjunção "e", revelando tratar-se de mais um movimento efetuado pelos autores do artigo e não de uma ação inserida em outra como poderia estar sugerido pelo uso de "no qual", o que parece sustentar a dificuldade de entendimento da significação do termo. Há a adição de um acento em "papéis".

No quinto parágrafo, o termo "sessão" continua sendo assinalado pela professora e mantido na segunda versão. Há um problema de regência em "é explicado sobre", o qual Sara resolve com a supressão de "sobre". Liane assinala a necessidade de perceber que o conector "onde" é inadequado. No entanto, o mecanismo de retomada sugerido pela aluna na segunda versão manteve-se inadequado. A necessidade de se rever a

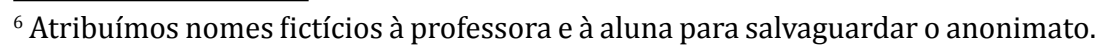


estrutura de um trecho foi resolvida com supressão. Já o questionamento referente à falha de concordância em "é esclarecido algumas questões", é resolvido com a substituição do verbo "ser" na terceira pessoa do singular pelo verbo "ser" na terceira pessoa do plural.

Atentemos para o seguimento da segunda página de cada texto.

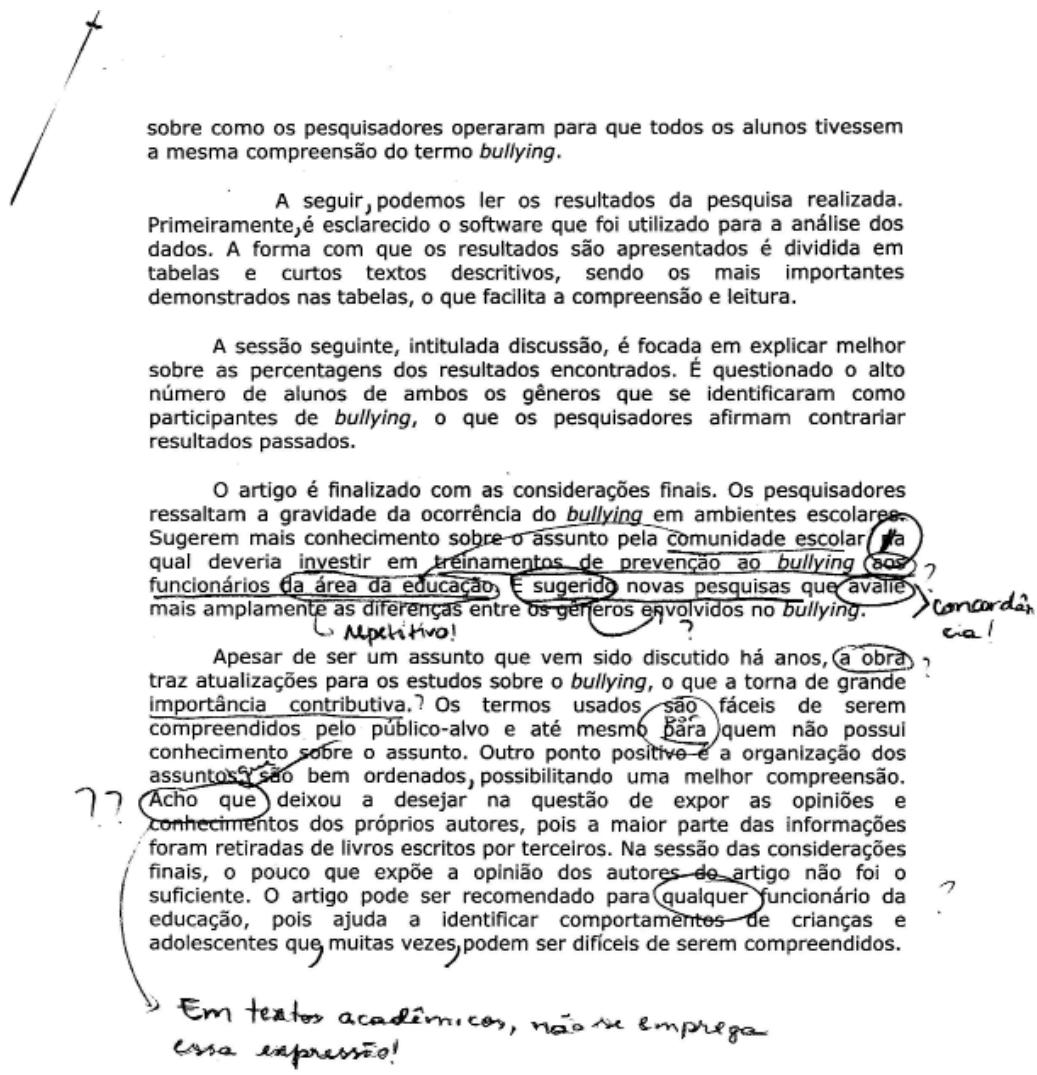

Versão 1 - página 2 
pesquisadores operaram para que todos os alunos tivessem a mesma compreensão do termo bullying.

A seguir, podemos ler os resultados da pesquisa realizada. Primeiramente, é esclarecido o software que fol utilizado para a análise dos dados. A forma com que os resultados são apresentados é dividida em tabelas e curtos textos descritivos, sendo os mais importantes demonstrados nas tabelas, o que facilita a compreensão e leitura.

A sessão seguinte, intitulada discussão, é focada em explicar melhor gebre as percentagens dos resultados encontrados. É questionado o alto número de alunos de ambos os gêneros que se identificaram como participantes de bullying, o que os pesquisadores afirmam contrariar resultados passados.

O artigo é finalizado com as considerações finais. Os pesquisadores ressaltam a gravidade da ocorrência do bullying em ambientes escolares. Sugerem mais conhecimento sobre o assunto pela comunidade escolar, a qual deveria investir em treinamentos de prevenção ao bullying. São sugeridas novas pesquisas que avaliem mais amplamente as diferenças entre os gêneros envolvidos no bullying.

O artigo é de grande importância, pois tráz atualizações no estudo sobre o bullying. Apesar de ser um assunto que vem sido discutido há anos, existe, ainda, e sempre existirá, uma grande necessidade de novas pesquisas no assunto, pois sofre constantes mudanças, de acordo com a época e cultura. Os termos utilizados são fáceis de serem compreendidos pelo público-alvo e até mesmo por quem não possui conhecimento sobre o assunto. Outro ponto positivo é a organização, os assuntos são bem ordenados, possibilitando uma melhor compreensão. 0 artigo pode ser

7 recomendado a todos os funcionários? da área da educação, pois ajuda a identificar comportamentos de crianças e adolescentes que, muitas vezes, podem ser difíceis de serem compreendidos.

Versão 2 - página 2

No sexto parágrafo, Liane solicita a adição de duas vírgulas na segunda versão antes de adjuntos adverbais, as quais são inseridas pela aluna na segunda versão.

No sétimo parágrafo, há novamente a insistência para a correção de "sessão". Também é feito um traço na expressão "sobre" para que seja suprimida, mas ambas são realizadas somente na segunda versão, uma vez que tais correções já haviam sido mencionadas anteriormente. Essa manutenção tem relação direta com a aparente dificuldade de compreensão das razões para tais alterações, outrora já questionadas pela revisora.

No oitavo parágrafo, são assinaladas as expressões "comunidade escolar" e "da área da educação", que são ligadas por um traço indicativo de relação. Sara soluciona o problema de sentido expresso pela repetição das ideias através da supressão da segunda. A aluna também atenta para as expressões circuladas e com indicação de problemas de concordância. 
Ela substitui "É sugerido" por "São sugeridas" e "avalie" por "avaliem" a fim de ajustar a concordância com o sujeito da oração.

O nono e último parágrafo é o que apresenta o maior número de interferências da educadora e foi o que mais suscitou modificações na segunda versão. Antes da primeira oração desse parágrafo, foi adicionada uma outra na segunda versão: "O artigo é de grande importância, pois traz atualizações no estudo sobre o bullying". A professora pede novamente que o último termo "bullying" seja colocado em itálico na segunda versão assim como Sara havia feito na primeira. Parece ser a inserção desse período a solução encontrada por Sara para o estranhamento de Liane diante do emprego de "obra" para referir-se ao "artigo" e do emprego de "importância contributiva".

Ainda nesse parágrafo, o primeiro período é deslocado e passa a ser a segunda oração e é acrescido de novas ideias: "Apesar de ser um assunto que vem sido discutido há anos, existe, ainda, e sempre existirá, uma grande necessidade de novas pesquisas no assunto, pois sofre constantes mudanças, de acordo com a época e com a cultura." As vírgulas em destaque foram sugeridas na segunda versão.

Na oração iniciada por "Os termos usados são fáceis" ocorre a primeira modificação sem interferência da revisora: a aluna substitui "usados" por "utilizados". A professora pede a substituição de "para quem" por "por quem", que é devidamente realizada pela estudante. Também chama a atenção os movimentos na oração "Outro ponto positivo é a organização dos assuntos, são bem ordenados,..." em que há a sugestão, na primeira versão, da inserção de um "que" antes do verbo ser e da vírgula após "ordenados", uma vez que a aluna resolve de maneira diferente: ela não insere o pronome relativo "que" e prefere formar uma nova oração: "Outro ponto positivo é a organização, os assuntos são bem ordenados, possibilitando uma melhor compreensão." A oração iniciada por "Acho que" foi simplesmente suprimida, movimento que exigiria bastante reflexão junto aos alunos acerca da autoria em seus textos. Há uma oração um tanto quanto confusa que a própria aluna decide suprimir: "Na sessão das considerações finais, o pouco que expõe a opinião dos autores do artigo não foi o suficiente."

A supressão, nesses casos, parece configurar uma maneira imediata de solucionar o problema em vez de retomar o período e ressignificá-lo.

No último período do parágrafo, a aluna insere duas vírgulas sugeridas por Liane para intercalar a expressão "muitas vezes", mas não 
consegue resolver adequadamente a colocação de "qualquer" na primeira versão, pois ao substituir por "a todos os funcionários", ainda não ficou clara a delimitação de para quem o artigo é realmente recomendado.

Diante de tamanha dificuldade em projetar o endereçamento de seu texto, é possível perceber que, embora haja interferência do professor, que poderia provocar o deslocamento do endereçamento do texto a outros leitores, não há demonstração de troca que efetive essa ressignificação. 0 que acabamos por encontrar são modificações que não acarretam em implicações significativas para o sentido do texto.

Agustini et al (2013) elucida a projeção de (inter)locutor que se coloca em tela, na escrita, uma vez que há dizeres "atribuídos" a outros, que funcionam na textualidade da escrita, de modo que, ao (se) enunciar, o locutor faz outros locutores (se) dizerem. Para os autores, ancorados nos pressupostos benvenistianos, há uma coenunciação em funcionamento na escrita. No caso da escrita em âmbito universitário, portanto, o aluno acaba por, no processo, elaborar o seu texto sob a insígnia do discurso pedagógico em jogo.

Mesmo com a insistência da professora com relação a pensar sobre o alocutário durante as aulas, os alunos demonstraram muita dificuldade em encontrar como e a quem recomendar a resenha. Isso é perceptível em vários textos do corpus e, muitas vezes, compromete o sentido do texto como um todo, interferindo no processo de sintagmatização para que o scriptor semantize e então construa sentidos. Se o alocutário não está claro, evidentemente a emergência da subjetividade e a constituição dos sentidos ficam comprometidas.

Ao se produzir duas versões, muito do processo não pode, infelizmente, ser visualizado. Obviamente não há como resgatar toda a enunciação, pois cada ato enunciativo se perde assim que proferido e já é re-significado na próxima vez. É possível perceber as marcas desse processo nas versões, mas de forma um tanto quanto oculta, pois o traço da professora, muitas vezes, fica mais evidente do que a do estudante. É válido, porém, o exercício daquele que corrige de atentar para a primeira versão produzida a fim de valorizar os movimentos dos alunos, de melhor avaliá-los. Tratase de uma tentativa interessante de permitir que o aluno re-invente o seu dizer na troca (inter)subjetiva com o professor, ainda que se $r$-inventar na própria escrita dependa de compreender o seu papel e de querer fazer sentido para um determinado público. 


\section{Palavras finais}

O estabelecimento de laço entre professor e aluno na escrita não é tarefa fácil porque pressupõe um alto grau de alinhamento e de acolhimento da escrita desse aluno e da compreensão da complexidade desse processo. Reconhecemos, no entanto, na professora-revisora, uma tentativa de efetuar esse laço, ainda que a amarra não tenha sido de todo efetivada.

Acreditamos, contudo, que a análise do processo constitui uma chave importante para, aos poucos, o aluno sentir-se motivado a ampliar o endereçamento dos textos. Para tanto, o professor pode e deve problematizar o processo de escrita de seus alunos junto a eles, fazendo com que, por meio da reescrita, possam ressignificar a si mesmos e a sua maneira de estar na língua. Por fim, podemos dizer que o laço é um ponto fundamental a ser observado, pois à medida que o professor atua como mediador e problematizador do texto do aluno, ele acaba concedendo-lhe um novo lugar de enunciação, permitindo-lhe apropriar-se do texto como espaço de reinvenção.

\section{Referências}

AGUSTINI, C.L.H. et al. Rasuras em manuscritos escolares e implicações enunciativas: da projeção da (inter)locução à transmissibilidade. In: Letras \&Letras, v.29, n.1, 2013, p.1-20.

ARAÚJO, É. D. Implicações subjetivas na relação professor-aluno: um olhar sobre o processo de (re)escrita de manuscritos escolares. 2014, 211f. Dissertação (Mestrado) - Curso de Linguagem, Texto e Discurso, Instituto de Letras e Linguística, Universidade Federal de Uberlândia, Uberlândia, 2014. Disponível em: <http:// repositorio.ufu.br/handle/123456789/4129>. Acesso em: 13 abr. 2014.

ARESI, F. Os índices específicos e os procedimentos acessórios da enunciação. ReVEL,

v.9, n.16, 2011. Disponível em: <http://www.revel.inf.br/files/artigos/revel_16_ os_indices_especificos.pdf $>$. Acesso em: 17 maio 2015.

BENVENISTE, É. A forma e o sentido na linguagem (1966). In: BENVENISTE, É. Problemas de Linguística Geral II. Campinas: Pontes, 2006a.

. A linguagem e a experiência humana (1965). In: BENVENISTE, É. Problemas de linguística geral II. Campinas: Pontes, 2006b.

. A natureza dos pronomes (1956). In: BENVENISTE, É. Problemas de Problemas de linguística geral I. Campinas: Pontes, 2005a. 
BENVENISTE, É. Da subjetividade na linguagem (1958). In: BENVENISTE, É. Problemas de Problemas de linguística geral I. Campinas, SP: Pontes, 2005b

. Estrutura das relações de pessoa no verbo (1946) In: BENVENISTE, É. Problemas de linguística geral I. Campinas: Pontes, 2005c.

. O aparelho formal da enunciação (1970). In: BENVENISTE, É. Problemas de linguística geral II. Campinas: Pontes, 2006c.

. Semiologia da Língua (1969). In: BENVENISTE, É. Problemas de linguística geral II. Campinas: Pontes, 2006d.

. Vista d'olhos sobre o desenvolvimento da linguística (1963). In: BENVENISTE, É. Problemas de linguística geral I. Campinas: Pontes, $2005 \mathrm{~d}$.

. Dernières Leçons. Paris: Editora Gallimard, 2012, 210f. Resenha de Agustini et al. Resenha. Revista Línguas e instrumentos linguísticos, jul./dez. 2012.

CAPT, V. Poétique des écrits bruts. Limoges: Éditions Lambert-Lucas, 2013.

DESSONS, G. Une antropologie du langage. In: DESSONS, G. Émile Benveniste, l'invention du discours. Paris: Editions In Press, 2006, p.41-55.

DUFOUR, D-R. Os mistérios da trindade. Rio de Janeiro: Companhia de Freud, 2000.

FENOGLIO, I. Déplier l'écriture pour re-lire l'article publié. Les manuscrites de «L'appareil formel de l'énonciation» d'Émile Benveniste. In: BRUNET, Émilie; MAHRER, Rudolf. Relire Benveniste: réceptions actuelles des Problèmes de linguistique générale. Bruxelles: Academia, coll.» Sciences du langage: carrefours et points de vue», n.3, 2011, p.263-265; p.275-277

FLORES, V. N. Sujeito da enunciação: singularidade que advém da sintaxe da enunciação. DELTA [on-line], 2013. Disponível em: <http://www.scielo.br/pdf/delta/ v29n1/05.pdf>. Acesso em: 16 abr.2015.

FLORES, V. N.; TEIXEIRA, M. As perspectivas para o estudo das formas complexas do discurso: atualidades de Émile Benveniste. ReVEL, edição especial n.7, 2013.

MELLO, V. H. D. A sintagmatização-semantização: uma proposta de análise de texto. 2012. 145 f. Tese (Doutorado) - Programa de Pós-Graduação em Letras, Instituto de Letras, Universidade Federal do Rio Grande do Sul, Porto Alegre, 2012. Disponível em: <http://www.lume.ufrgs.br/bitstream/handle/10183/56031/000858559. pdf?sequence=1>. Acesso em: 27 abr. 2015.

NORMAND, C. Leituras de Benveniste: algumas variantes sobre um itinerário demarcado. Porto Alegre. Letras de Hoje, v.44, n.1, p.12-19, jan./mar. 2009. Disponível em: <http://revistaseletronicas.pucrs.br/ojs/index.php/fale/article/viewFile/5647/4115>. Acesso em: 4 maio 2015.

NUNES, P. Á. A prática tradutória em contexto de ensino (re)vista pela ótica enunciativa. 2012, 239f. Tese (Doutorado) - Programa de Pós-Graduação em Letras, Instituto de Letras, Universidade Federal do Rio Grande do Sul, Porto Alegre, 2012. Disponível em: <http://www.lume.ufrgs.br/bitstream/handle/10183/55982/000858935.pdf?sequence=1>. Acesso em: 9 mar. 2015. 
ROCHA, L. C. P. Um olhar enunciativo para interlocuções entre médico e paciente em consultas ambulatoriais pelo Sistema Único de Saúde. 2014, 95f. Dissertação (Mestrado) - Curso de Linguística Aplicada, Unidade Acadêmica de Pesquisa e Pós-Graduação, Universidade do Vale do Rio dos Sinos, São Leopoldo, 2014. Disponível em: <http://biblioteca.asav.org.br/vinculos/00000A/00000AA4.pdf>. Acesso em: 5 maio 2015.

TEIXEIRA, M. O estudo dos pronomes em Benveniste e o projeto de uma ciência geral do homem. Desenredo. Revista do Programa de Pós-Graduação em Letras da Universidade de Passo Fundo, v.8, n.1, p.71-83, jan./jun. 2012. 


\section{A escrita na universidade: uma reflexão a partir do que os alunos dizem em seus textos}

Luciene Juliano Simões

Maristela Juchum

Nos últimos anos, no Brasil, alguns pesquisadores (Fischer, 2007, Motta-Roth e Hendges, 2010, Marinho, 2010, Fiad, 2011) vêm demonstrando uma maior preocupação em relação à leitura e à escrita dos alunos que ingressam na universidade. As recentes pesquisas apontam que os estudantes calouros apresentam sérias dificuldades em produzir gêneros tipicamente da esfera acadêmica (na modalidade escrita podemos citar o resumo, a resenha, o relatório, entre outros); essas dificuldades são bastante acentuadas quando se trata de alunos atendidos pelas instituições privadas - geralmente, oriundos de camadas sociais menos favorecidas e que há até pouco tempo não tinham acesso ao ensino de nível superior. Diante de um novo perfil de aluno, precisamos produzir novos conhecimentos e novos projetos curriculares para atender às necessidades desses estudantes.

Nesse contexto, temos assistido à criação de disciplinas com o propósito de preparar os estudantes para dominar os textos e as práticas necessárias ao seu sucesso acadêmico (cf. Lea; Street, 1998; 2006; Street, 2009). É o caso da disciplina de Leitura e Produção de Texto I que passou a integrar o currículo das universidades. Subjacente a tal medida, encontrase a "queixa frequente entre professores universitários de que os alunos que entram na universidade estão mal preparados para o ensino a que vão ser expostos", alegando que os saberes e competências de leitura e escrita 
desses alunos não estão adequados às várias comunidades discursivas que integram a universidade (Henderson; Hirst, 2006, p.25). Segundo essas autoras, "o letramento acadêmico é construído no interior de discursos do déficit e remediação" (Henderson; Hirst, p.26).

Segundo Marinho (2010), essa dificuldade ou lacuna de saber costuma ser simplificada por outra crença subjacente aos discursos correntes segundo a qual basta aprender (e principalmente treinar) um conjunto de estratégias textuais, de conteúdos gramaticais, de regras e convenções típicas do texto acadêmico, para que essas dificuldades sejam resolvidas.

Não diminuindo a importância das habilidades e competências linguísticas relacionadas à textualidade, aos aspectos e dispositivos formais e da linguagem acadêmica, argumento que nesse nível não estariam as maiores dificuldades dos nossos estudantes e nem seria muito difícil arregimentar estratégias para melhoria das habilidades desses estudantes. $O$ mais importante seria então convidar esses alunos a interrogar as práticas acadêmicas de letramento das quais eles participam, buscando compreender como se constituem essas práticas, desenhando um quadro mais complexo de questões relacionadas, sim, a habilidades linguísticas, mas sobretudo a dispositivos que refletem relações de poder, disputas e violência simbólica (Marinho, 2010, p.6, grifos nossos).

Nessa mesma perspectiva, Russel (2009, p.247) afirma que a educação em massa traz consigo uma visão pré-moderna de escrita como conjunto único e generalizável de habilidades que se aprende uma vez e para sempre. Considera-se que os alunos cuja escrita não está em conformidade com os padrões da academia em específico apresentam algum déficit que precisa ser remediado antes que eles sejam admitidos na universidade.

Contrariando essa ideia, Fischer (2010) alega que é nos eventos de letramento acadêmico que os alunos vão construindo os seus saberes acadêmicos/científicos e, para além disso, também os posicionamentos ideológicos, significados culturais e estruturas de poder que, em conjunto, constituem o modo cultural de usar os textos.

Bakhtin (1997, p.303) tece um forte e conhecido argumento para se repensar certa maneira com que se lida com as dificuldades de leitura e de escrita dos alunos na universidade: o domínio de um gênero é uma forma de ação social. Isso significa que é possível ter um bom domínio da língua, 
mas ser inexperiente na atividade de moldar os gêneros. A experiência é algo constitutivo da prática nas comunidades que fazem uso de determinados gêneros, tornando-se, assim, condição indispensável para uma interação verbal bem-sucedida. Assim, torna-se mais coerente esperar e aceitar que os alunos universitários se familiarizem e aprendam a ler e a escrever os gêneros acadêmicos, sobretudo, na instituição e nas esferas do conhecimento em que são constituídos, quando se inserem nas práticas de escrita universitária. E onde, pois, os estudantes poderiam se inserir nas práticas de leitura e escrita de gêneros acadêmicos, se não nas próprias universidades?

\section{A escrita na universidade}

Este trabalho situa-se na discussão sobre escrita na universidade esboçada acima e tem como objetivo principal observar, com base em discussões recentes sobre o letramento acadêmico, feitas por estudiosos dos Estudos sobre o Letramento, o que alunos universitários dizem sobre suas escritas, mais especificamente, como eles veem suas escritas em confronto com o que é esperado no contexto acadêmico.

Segundo Fiad (2011), uma pergunta que fazia parte das discussões sobre a escrita na universidade nos anos 80 era a seguinte: Por que os estudantes chegam à universidade "sem saber escrever"? Para a autora, se a pergunta podia ser essa naquele tempo, hoje não pode mais ser a mesma. "Não é mais possível dizer que os estudantes não sabem escrever, de modo genérico e absoluto" (Fiad, 2011, p.360).

Se, naquela época, era possível ver o desempenho na escrita como habilidades individuais de ler e escrever, adquiridas principalmente na escola básica, hoje é necessário situar qualquer prática envolvendo leitura e a escrita em um contexto sócio-histórico-cultural específico.

São muitas as pessoas que, dominando magnificamente a língua, sentem-se logo desamparadas em certas esferas da comunicação verbal, precisamente pelo fato de não dominarem, na prática, as formas do gênero de uma dada esfera. Não é raro o homem que domina perfeitamente a fala numa esfera da comunicação cultural saber fazer uma explanação, travar uma discussão científica, intervir a respeito de problemas sociais, calar-se ou então intervir de uma maneira muito desajeitada numa conversa social (Bakhtin, 1997, p.303). 
Levando essas reflexões ao ensino superior, segundo Fischer (2007), muitas questões diferenciam o meio acadêmico de outros contextos de ensino. As práticas de leitura e escrita encontradas no ensino superior diferem das práticas anteriores à entrada na universidade.

Neste trabalho, toma-se o conceito de letramento como a relação de uso que um indivíduo ou uma comunidade estabelece com a escrita, rejeita-se o discurso da crise. Ao contrário do que dizem muitos professores universitários em relação à escrita de seus alunos, entende-se que esses estudantes são letrados e, muito provavelmente, não se inseriram ainda nas práticas letradas esperadas no contexto acadêmico.

Analisar e entender o que os alunos escrevem sobre suas escritas é um modo de penetrar nessas práticas de escrita que estão em conflito com as práticas do letramento acadêmico, no momento de entrada na universidade. Assim, analiso textos produzidos por alunos de diferentes cursos, matriculados na disciplina de Leitura e Produção de Texto I, de um Centro Universitário situado no Vale do Taquari/RS. Essa disciplina é obrigatória para todos os alunos da instituição, tem o intuito de lhes ensinar a escrita acadêmica, que é esperada nas diferentes disciplinas do currículo de cada curso.

Como docente dessa disciplina, na primeira aula, proponho aos estudantes a escrita de um texto no qual relatem experiências relacionadas ao seu processo de leitura e escrita desde a entrada na escola de ensino fundamental. Dentre os textos produzidos pelos alunos no início do semestre A de 2013, selecionei os textos de uma turma composta por 45 alunos. Para a realização deste estudo, tomo como referência o texto produzido por cada um dos alunos que integraram a turma, totalizando 45 textos ${ }^{1}$.

Com base nas reflexões sobre letramento acadêmico trazido no interior dos Novos Estudos do Letramento, analiso os textos, buscando fazer uma aproximação entre as reflexões feitas pelos alunos e as reflexões desses autores, que têm discutido o ensino da escrita no contexto acadêmico considerando os alunos como sujeitos letrados e iniciantes em práticas letradas até então desconhecidas. Primeiramente apresento alguns pressupostos dos Novos Estudos do Letramento, nos quais está baseada a discussão feita, após discuto os textos dos alunos.

\footnotetext{
${ }^{1}$ Os textos que compõem o corpus do trabalho integram o acervo de pesquisa aprovada pelo COEP, Comitê de Ética e Pesquisa do Centro Universitário em que a pesquisa foi desenvolvida. Os participantes assinaram o Termo de Consentimento dos materiais para fins de pesquisa.
} 


\section{Os novos estudos do letramento}

Os estudiosos do letramento que integram a área dos Novos Estudos do Letramento (Street 1994, 2003; Barton 2007; Gee 2004) propõem que as práticas de letramento, como práticas sociais que são, têm caráter situado, ou seja, têm significados específicos em diferentes instituições e grupos sociais. Desse modo, assumindo que as práticas de uso da escrita são diferentes, ou seja, que os usos diferem de acordo com o contexto em que são empregados, é possível falar em letramento acadêmico. Mais ainda: assume-se que há usos específicos da escrita no contexto da universidade, usos que diferem de outros contextos.

Boa parte das pesquisas sobre letramento acadêmico surge a partir da observação das escritas de estudantes oriundos de diferentes classes sociais e etnias. Ao entrarem na universidade, os estudantes são requisitados a escreverem diferentes gêneros, com os quais não estão familiarizados em suas práticas de escrita em outros contextos e são mal avaliados por seus professores. Na verdade, como apontam autores como Lea e Street (1999), começam a ficar evidentes os conflitos entre o que os professores esperam das escritas e o que os alunos escrevem; ou seja, no contexto da universidade, em que geralmente não são reconhecidos diferentes letramentos (nesse caso, os dos alunos e o da universidade), os letramentos dos alunos não são reconhecidos e estes são vistos como sujeitos iletrados pela universidade.

A noção de letramento acadêmico, desenvolvida dentro da área dos Novos Estudos do Letramento (Street, 1984; Barton, 2007; Gee, 2004), constitui-se em uma tentativa de extrair as implicações dessa abordagem para o entendimento das questões relativas à aprendizagem no ensino superior. Lea e Street (1998) apontam que a escrita do estudante universitário é compreendida a partir de três principais perspectivas ou modelos: estudo das habilidades, socialização acadêmica e letramento acadêmico.

A primeira abordagem compreende o letramento como um conjunto de habilidades individuais e cognitivas que os estudantes precisam adquirir e desenvolver e que poderão transferir para os diversos contextos da universidade. Ver o letramento apenas dentro desse modelo é desconsiderar a trajetória anterior de letramento do aluno e atribuir a ele a responsabilidade de desenvolver competências cognitivas e metacognitivas de leitura e escrita para inserir-se no contexto da universidade, de manei- 
ra que qualquer insucesso com o uso da escrita, nesse domínio, passa a ser de inteira responsabilidade do aluno.

É necessário destacar que não estou dizendo que o aluno não deva desenvolver habilidades de leitura e escrita específicas da esfera acadêmica, mas, para que isso aconteça, é preciso considerar suas experiências de leitura e escrita antes de ingressar na universidade, com o objetivo de conhecer o que o aluno lê, como lê, o que escreve e como escreve ao ingressar na universidade.

O modelo da socialização acadêmica parte do princípio de que o professor é responsável por introduzir os alunos na cultura universitária, com o intuito de que eles assimilem os modos de falar, pensar, interpretar e usar as práticas de escrita que circulam na esfera acadêmica. Esse modelo parte da concepção de que os gêneros discursivos acadêmicos são relativamente homogêneos e, sendo assim, uma vez que o aluno aprende as convenções que regulam esses gêneros, estará habilitado a se engajar nas práticas letradas que permeiam essa instância. Esse modelo passa a ideia de que a esfera acadêmica é imutável e suas identidades facilmente identificadas, ou seja, uma vez aprendidos os gêneros do discurso específicos das disciplinas, os estudantes se tornariam capazes de reproduzi-los sem problemas.

A abordagem do letramento acadêmico, compartilhada pelos pesquisadores dos Estudos do Letramento, entende os múltiplos letramentos que permeiam a instância universitária como práticas sociais. Assim, o modelo do letramento acadêmico pode ser caracterizado por concentrar-se nos significados que os alunos, professores e universidade atribuem à escrita, partindo de questões epistemológicas que envolvem as relações de poder estabelecidas entre esses sujeitos, no que diz respeito ao uso da língua nessa esfera social pelos próprios participantes.

Assumir essa concepção de letramento implica reconhecer que cada indivíduo ou grupo social possui algum tipo de conhecimento sobre a escrita e seu uso em práticas sociais. Desse modo, os alunos que ingressam na universidade são sujeitos letrados e que, portanto, trazem para essa esfera concepções de leitura e escrita construídas ao longo da sua vida, ainda que essas concepções nem sempre sejam suficientes para que eles se engajem de modo imediato nas práticas letradas do domínio acadêmico. 


\section{A tarefa de produção textual}

Com o propósito de conhecer melhor os alunos que integram a turma (e, nesse caso, participantes da pesquisa) planejou-se uma tarefa de produção textual com tal finalidade. Adota-se a concepção teóricometodológica oferecida por Freire (1993) e por Street (2003): conhecer os participantes e o contexto de ação, pois deles se dará a intervenção.

Acontece que o bom começo para uma boa prática seria a avaliação do contexto em que ela se dará. A avaliação do contexto significa um reconhecimento do que vem nele ocorrendo, como e por quê. Nesse sentido, esse pensar crítico sobre o contexto que implica avaliá-lo, precede a própria programação da intervenção que pretendemos exercer sobre ele, ao lado daqueles e daquelas com quem trabalharemos (Freire, 1993, p.15) .

Assim, a geração de dados desta pesquisa foi viabilizada por uma tarefa de produção textual que orientava o aluno a escrever um texto no qual contasse aos colegas sobre práticas de leitura e escrita vivenciadas por ele durante a sua vida. A finalidade da tarefa consistia em conhecer as experiências de cada aluno em relação à leitura e à escrita, socializar e valorizar conhecimentos prévios dos participantes e direcionar o planejamento do semestre. Os textos circularam pela sala de aula e foram lidos pelos colegas e pela professora, e após foram comentados pelos participantes.

Esse momento foi significativo no sentido de a leitura dos textos ter possibilitado com que os integrantes da turma se conhecessem. Não foram poucos os alunos que, após a leitura de um texto, comentavam sobre questões com as quais se identificavam. Cabe ressaltar especialmente o quanto algumas experiências de leitura e escrita vivenciadas durante o ensino básico foram comentadas pelos alunos. Entre elas, idas à biblioteca, livros cujas leituras eram obrigatórias durante o ensino médio, seminários de leitura organizados pelos professores, etc. Dentre as questões ligadas à escrita, os alunos comentaram muito sobre a dificuldade em escrever alguns textos solicitados pelos seus professores que, muitas vezes, tinham apenas a finalidade de avaliar o estudante.

Embora haja uma ilusão compartilhada de que escrever sobre suas próprias experiências é sempre mais fácil, tem-se a convicção de que essa atividade de escrita não é simples ou espontânea. Os participantes tiveram 
que se lembrar de várias situações vividas (boas ou não), selecioná-las e reavaliá-las tendo em vista a finalidade da escrita e o leitor, no caso, a professora e os demais colegas da turma.

De modo geral, os quarenta e cinco textos produzidos pelos participantes evocaram memórias de leitura e escrita relacionadas à escola de ensino básico. Ao ler os textos, percebi, nas escritas, remissões a reflexões feitas sobre a própria escrita, destacando-se reflexões sobre dois momentos: a escrita antes de entrar na universidade e o ideal de escrita a ser atingido após o ingresso no meio acadêmico. Esses dois momentos trazem à tona, em uma análise à luz do letramento acadêmico, os conflitos existentes entre a escrita que produziam e a que é exigida pelos professores na universidade.

\section{Conflitos: como eu escrevo e como devo passar a escrever}

Para analisar o que os textos evidenciam sobre a escrita antes e após o ingresso na universidade, apresento trechos dos textos destacando aspectos que se repetem nas escritas dos alunos. A identidade dos alunos está suprimida em todos os casos, pois não é relevante para a análise.

Como procedimento de análise, destacam-se os momentos dos textos em que ficam visíveis as oposições expressas pelos autores entre um "antes" e um "depois" de ingressar na universidade. Mais precisamente, busca-se responder às seguintes questões: Quais são os tópicos mais recorrentes que os alunos apresentam em seus textos? Os tópicos selecionados e desenvolvidos pelos alunos em seus textos demonstram algum fato recorrente sobre o que significa entrar na universidade? Os itálicos foram acrescentados por mim, como forma de destaque. Vejamos os seguintes trechos:

1. Antes de ingressar na universidade não tinha uma exigência tão grande nas questões de escrita, e isso foi uma dificuldade que encontrei, ou seja, trabalhar com as regras técnicas (ABNT) na universidade é algo meio complexo, e por eu não ter o conhecimento prévio disso as coisas se tornam mais complicadas."

2. "Na minha vida escolar escrevi muito pouco, quase nada, apenas resumos de outras disciplinas. Sinto que na universidade a minha escrita ainda não está adequada aos textos que preciso escrever." 
3. “Com relação à escrita, acredito que tenha dificuldade de aprofundar por questões profissionais. Como trabalho com TV e propaganda, utilizo a linguagem mais 'falada', coloquial. Aqui na universidade preciso usar uma linguagem mais formal."

4. "As expectativas em relação à universidade são bem positivas, mas sei que vou precisar aprender a escrever outros textos, pesquisar novos conteúdos e compartilhar experiências com outros colegas. Significa que preciso me adaptar às novas exigências."

Nesses quatro trechos, destaco, inicialmente, expressões como antes de ingressar na universidade não tinha uma exigência tão grande nas questões de escrita, na universidade a minha escrita ainda não está adequada aos textos que preciso escrever, aqui na universidade preciso usar uma linguagem mais formal, sei que vou precisar aprender a escrever outros textos, que indicam que os alunos reconhecem que há uma diferença entre os textos que escreviam antes do ingresso na universidade e os que lhes são exigidos pelos professores no meio acadêmico. Essas expressões introduzem práticas que, supostamente, não eram conhecidas pelos estudantes ou que, ao menos, não eram frequentes em contextos anteriores de escrita, como escola.

No conjunto de trechos dos textos abaixo citados, podemos destacar a menção explícita, pelos estudantes, a gêneros que faziam parte de suas práticas de escrita no ensino básico:

5. "Na escola normalmente fazíamos resumos e redações."

6. "Durante o ensino médio uma das propostas da escola era preparar o aluno para a redação do vestibular."

7. "Na escola escrevia músicas e muitos poemas."

8. "No ensino médio a escrita era destinada a variados assuntos, mas a redação se destacava entre os textos que tínhamos que escrever."

9. "O que escrevíamos mais na escola eram redações que a professora pedia a fim de dar nota."

10. "O que mais escrevia no ensino básico eram resenhas, redações, crônicas e charges".

Nesses trechos, talvez a mudança mais significativa tenha sido a consciência de que os textos que devem ser escritos na universidade diferem dos textos que eram escritos no ensino básico.

Se os gêneros que circulam na academia diferem dos acima citados, isso evidencia que o aluno, ao ingressar na universidade, precisa 
engajar-se em uma prática de escrita e leitura até então não familiar para ele.Segundo Street (1994), a escrita acadêmica é um ato social. 0 aluno carrega experiências anteriores de produção de sentidos, ou seja, diferentespráticas que ecoam nas novas práticas que a universidade impõe, em outras palavras, tudo o que o aluno já sabe sobre a escrita é relevante para a escrita que lhe será exigida na universidade.

Trechos de textos de outros estudantes trazem reflexões que se aproximam. Uma recorrência é a referência à escrita com a finalidade de ser avaliado pelo professor, conforme podemos observar no trecho 9 . Vejamos outros exemplos:

11. "A escrita servia para o professor atribuir uma nota."

12. "Minha professora trabalhava com a escrita de textos, mas na hora da prova ela cobrava a gramática."

Para Russel (2009), a avaliação é algo que liga a escrita da educação básica com a escrita no ensino superior. Significa dizer que, para os alunos, a avaliação é conhecida como uma das finalidades comunicativas da produção textual desde o ensino fundamental. Sabemos, no entanto, que essa é apenas uma finalidade e se focarmos nossa atenção na avaliação (notas) isso pode nos afastar das outras finalidades, entre elas, a de fazer com que os alunos escrevam com o propósito de aprender examinando e manipulando ideias, sintetizando, analisando, explorando. Pela recorrência ao aspecto da avaliação, podemos supor que esse é um aspecto muito explicitado nas práticas de escrita escolares, quando a escrita solicitada pelo professor aos seus alunos tem como finalidade avaliá-los. No entanto, parece que os alunos esperam que essa não seja a única finalidade da escrita na universidade, mesmo que saibam que continua sendo uma delas.

Em alguns trechos os estudantes explicitam a sua preocupação em se inserirem nas práticas de escrita da universidade:

13. "Aprender a escrever resumos, resenhas e artigos que tenham a ver com o meu curso."

Esse aspecto explicitado, muito provavelmente, mostra que o estudante tem um objetivo em relação à escrita na universidade, entendido como aprender a escrever determinados textos diferentes dos que escrevia na escola. Trata-se de uma tomada de consciência de que os gêneros textuais que lhe serão exigidos pelos professores na universidade são diferentes daqueles que faziam parte das práticas de leitura e escrita 
antes do ingresso na academia. Cabe ressaltar novamente a importância da experiência como um fator determinante do aprendizado e da apropriação das regras e disposições próprias dos gêneros acadêmicos, sustentando a proposta na teoria de gêneros do discurso formulada por Bakhtin.

Sabemos que a escrita na universidade é algo bastante especializado, muito mais especializado do que no ensino básico. Os alunos necessitam aprender a usar vocabulários especializados. É evidente que a falta de contato com os gêneros acadêmicos faz o aluno perceber a sua dificuldade em escrevê-los. Para Russel (2009, p.241), a escrita "não é uma habilidade generalizável que se aprende de uma vez por todas, mas uma conquista ou feito que pode ser desenvolvido, que requer muita prática”. 0 fato de saber que na universidade o aluno irá deparar-se com gêneros discursivos com os quais ele ainda tem pouco contato causa preocupação, isso pode ser verificado no seguinte trecho:

14. "Assusta-me o fato de ter que escrever um resumo ou uma resenha".

Sobre o trecho acima, é possível afirmar que o aprendizado da língua não é um aprendizado de formas, de uma gramática, mas é constitutiva do processo de socialização, especialmente a língua materna. 0 indivíduo se socializa através da língua; para Bakhtin (1979), através dos gêneros que se constituem por e para as atividades humanas, as interações sociais, em outras palavras, para que o aluno escreva resumos e resenhas precisa necessariamente inserir-se em práticas de leitura e escrita de textos desse gênero.

Nos trechos apresentados acima, confirma-se o conflito que se estabelece entre o que o aluno escrevia antes de entrar no meio acadêmico e a escrita que lhe será exigida pelos professores após o seu ingresso. Além disso, os textos mostram que o discurso dos professores sobre o déficit dos alunos é relevante, ou seja, os próprios alunos reconhecem que sentem dificuldades quando se trata de ler e escrever textos que lhes são exigidos na academia. Conforme Gee (2004), para que os alunos possam assumir-se insiders da comunidade acadêmica precisam entender o funcionamento dos inúmeros discursos que circulam nela, bem como as formas de constituição dos gêneros próprios dessa esfera.

Por outro lado, os textos também mostram que os alunos já escreviam vários textos antes de ingressarem na universidade, significa que eles têm experiências com a escrita. Fato que é incoerente com o discurso de alguns professores que alegam que o aluno não sabe nada. Segundo Gee 
(2004), os alunos encontram dificuldades na escrita acadêmica não por não saberem ler e escrever, mas pelo fato de não terem sido expostos, no ensino fundamental e médio, aos comportamentos linguísticos e sociais específicos do domínio acadêmico.

\section{Considerações finais}

É preciso reconhecer que o aluno é aprendiz da escrita na esfera acadêmica, em outras palavras, para que o aluno passe a compartilhar dos modos de agir, de valorizar, de acreditar do domínio acadêmico e a produzir de forma eficiente os gêneros discursivos dessa esfera, faz-se necessário que ele seja visto como sujeito de linguagem, como de fato o é, e com valores identitários construídos ao longo das suas práticas sociais prévias; esses aspectos são contemplados pelo modelo de letramento acadêmico proposto por Lea e Street (1998).0 fato de os professores projetarem nos textos dos alunos expectativas pouco compatíveis com as suas experiências e conhecimentos sobre esses gêneros pode representar uma relação tensa para o aluno.

Assim, uma das questões que parece ser urgente responder é esta: até que ponto se criam condições para os estudantes serem identificados e se identificarem como membros efetivos de um grupo, o da comunidade discursiva em que têm de ser bem-sucedidos?

Os textos analisados apontam que os alunos também reconhecem que desconhecem os gêneros textuais que integram as práticas de letramento na universidade. Para romper com o discurso do déficit, o planejamento didático do professor também necessita ser repensado/aprimorado, levando em conta as necessidades apresentadas pelos recém-ingressos, possibilitando-lhes o letramento acadêmico. Isso significa conceber o ensino e a aprendizagem como um processo de construção de saberes, não como uma transmissão de conhecimentos. Entretanto, para que esse processo seja exitoso, os objetos de ensino precisam fazer sentido para os alunos.

Adotar uma prática pedagógica que leve em conta o modelo do letramento acadêmico requer aproximar a universidade da vida. Segundo Kleiman (2005), a escrita precisa servir para atingir algum outro fim, que vai além da mera aprendizagem da escrita (a aprendizagem dos aspectos formais apenas), transformando objetivos circulares como "escrever para aprender a escrever" e "ler para aprender a ler" em ler e escrever 
para compreender e aprender aquilo que for relevante para a vida. Ainda, é preciso que a prática pedagógica se ajuste do individual para o social, da língua como código para a língua como interação, do modelo das habilidades para o modelo do letramento acadêmico.

\section{Referências}

BAKHTIN, M. Estética da criação verbal. São Paulo, Martins Fontes, 1997 (Tradução do francês Esthétique de la création verbal), 1979.

BARTON, D. Literacy; an introduction to ecology of written language. 2ed. Oxford: Blackwell Publishing, 2007.

FIAD, Raquel Salek. A escrita na universidade. Revista da ABRALIN, v. Eletrônico, n. Especial, p.357-369. 2 ${ }^{\mathrm{a}}$ parte, 2011.

FISCHER, A. A construção de letramentos na esfera acadêmica. Tese de Doutorado. Programa de Pós-Graduação em Linguística, Universidade Federal de Santa Catarina. Florianópolis, 2007.

FISCHER, A. Os usos da língua na construção de sujeitos letrados: relações entre a esfera escolar e a acadêmica. Acta Scientiarum. Language and Culture, 32 (2): 215-224, 2010.

FREIRE, Paulo. Professora sim, tia não: cartas a quem ousa ensinar. São Paulo, Olho d’Água,1993.

GEE, J. P. Situated language and learning: A critique of Traditional Schooling. New York: Routledge, 2004.

KLEIMAN, A. (Org.). Os significados do letramento: uma nova perspectiva sobre a prática social da escrita. Campinas: Mercado de Letras, 2005.

HENDERSON, R.; HIRST, E. Reframing academic literacy: re-examining a short course for "disadvantaged" tertiary students. English teaching: practice and critique, 6(2), 2006, p.25-38.

LEA, M. R. \& STREET, B. V. Student writing in higher education: an academic literacies approach. UKStudies in Higher Education, 23(2): 157-172, 1998.

LEA, M. R., \& STREET, B.V. the "academic literacies" model: theory and applications theory into Practice, 45(4), p.368-377, 2006.

LILLIS, T. Whose 'common sense'? Essayist literacy and the institutional practice of mystery. In: JONES, C.; TURNER, J.; STREET, B. (orgs). Students writing in the university: cultural and epistemological issues. Amsterdam. John Benjamins, 1999. p.127-140.

MARINHO, Marildes. A escrita nas práticas de letramento acadêmico. RBLA, Belo Horizonte, v.10, n.2, p.363-386, 2010.

MOTTA-ROTH, Désirée; HENDGES, Graciela Rabuske. Produção textual na universidade. São Paulo: Parábola Editorial, 2010. 
RUSSEL, D. R., LEA, M.; PARKER, J.; STREET, B.; DONAHUE, T. Exploring notions of genre in "academic literacies" and "writing across the curriculum": Approaches Across Coutries and Contexts. In: Bazerman, C.; Bonini, A. \& Figueiredo, D. (Eds.). Genre in a Chaging World. Colorado: The WAC Clearinghouse, 2009. Ch. 20, p.395423. Disponível em: http://wac.colostate.edu/books/genre/

STREET, B. Literacy in theory and practice. Cambridge: CUP, 1994.

STREET, B. What's "new" in new literacy studies? Critical approaches to literacy in theory and practice 2003. Current Issues in Comparative Education, 5 (2), 2003. 


\title{
O professor no processo de constituição do aluno pela escrita acadêmica
}

\author{
Ernesto S. Bertoldo
}

A entrada na ordem do discursivo-acadêmico ${ }^{1}$ parece constituir um desafio para os futuros professores de língua materna e estrangeira em formação nos cursos de licenciatura em letras. Tal desafio nos remete diretamente às questões sobre escrita e leitura, demandadas a alunos em seus processos de formação como professores de língua portuguesa e de línguas estrangeiras.

De modo geral, é possível dizer que o letramento acadêmico não encerra simplesmente "dominar" técnicas de escrita e de leitura, tendo em vista sua execução, reprodução ou mesmo "aplicação" na sala de aula. Para além disso, o letramento acadêmico pode ser trabalhado com vistas a propiciar aos alunos em formação condições para que os mesmos construam sentido do mundo da linguagem escrita e oral no qual estão imersos. Letrar-se, academicamente, assim, refere-se à constituição dos alunos em práticas discursivas que supõem, por sua vez, práticas acadêmicas letradas. 0 letramento acadêmico demanda, portanto, que os professores em formação se constituam em um conjunto de concepções e de procedimentos nos domínios específicos das instituições educacionais.

\footnotetext{
${ }^{1}$ Neste capítulo, não trabalharemos especificamente com o texto de Foucault (1971). Reconhecemos, no entanto, a partir de outros autores trabalhados, que esse termo advém de sua obra "A ordem do discurso", resultado de uma conferência proferida no Collège de France.
} 
A título de exemplificação, espera-se que aquele, academicamente letrado, seja capaz de ler um artigo sobre um determinado assunto de uma área de conhecimento específico, produzindo, a partir dessa leitura, interpretações coadunadas com as problemáticas tratadas por esse campo específico de conhecimento. 0 sujeito academicamente letrado seria, assim, aquele que, ao enunciar sobre esse ou aquele assunto em uma determinada área do conhecimento, demonstraria estar constituído daquelas práticas discursivas pertinentes aos modos de dizer e, em decorrência, de produzir conhecimento daquela área específica. Essa seria, a nosso ver, uma das condições que possibilitaria ao sujeito não só transitar pelas regras dos modos de dizer do discurso acadêmico, mas também resistir às suas próprias imposições.

Em sendo assim, um professor de línguas, tanto materna quanto estrangeira, será requisitado a responder por questões e /ou demandas que seu objeto de trabalho reclama. Deverá, por exemplo, tomar decisões sobre questões específicas ligadas à escolha ou não de livros didáticos na escola em que trabalha, participar de discussões sobre o conteúdo programático, fazendo reflexões consoantes com opções teóricas pertinentes ao seu campo de atuação, nesse caso específico, aos estudos sobre o ensino e a aprendizagem de línguas. Deverá, ainda, discutir a pertinência dos postulados de documentos oficiais sobre o ensino e a aprendizagem de línguas, dentre outras demandas características de sua atuação profissional que dizem respeito, via de regra, ao ensino de uma determinada língua propriamente dita.

Essa perspectiva do letramento acadêmico, então, como um lugar em que práticas discursivo-acadêmico-letradas são requeridas implica modos de dizer específicos constitutivos do discurso acadêmico; em última instância, são elas que possibilitam que os professores em formação respondam àquilo que advém como demanda de seu objeto de trabalho (o ensino de línguas). É nesse sentido que podemos afirmar que tais respostas extrapolam aquilo que se conseguiria somente pela via do senso comum. Em outras palavras, as respostas às demandas do objeto de trabalho, a serem enfrentadas pelos professores, implicam escolhas teóricas que, para advirem, estariam relacionadas ao fato de que esses professores nelas estariam constituídos, independentemente de qual fosse a opção ou as opções teóricas adotadas.

Ao nos referirmos à teoria, nesse caso, estamos, na verdade, nos remetendo aos saberes específicos necessários ao professor para 
responder a isso que seria da ordem da demanda de seu objeto de trabalho, conforme aludido anteriormente, ou seja, o ensino de línguas.

Julgamos ter, ainda que de forma concisa, descrito alguns aspectos constitutivos da entrada dos professores em formação na ordem do discurso acadêmico. E, em sendo assim, a reflexão de Gee (2012) sobre esse assunto parece-nos relevante para o entendimento do que estamos postulando, aqui, sobre as implicações da entrada na ordem desse discurso. Segundo o autor, no espaço discursivo-acadêmico, ler e escrever intransitivamente, qualquer coisa, é algo que não se cogita. Ler e escrever no espaço discursivo-universitário seria, então, ler e escrever a partir da constituição pela via de dizeres que encerram discursos outros, diferentes daqueles primários que nos constituíram desde a infância no nosso âmbito familiar.

Diante disso, o problema que se apresenta para os alunos, professores em formação, nesse processo de entrada na ordem do discurso acadêmico, refere-se ao fato de que nessa formação não temos a garantia de que a constituição dos alunos nas referidas práticas discursivas acadêmicas letradas e, em consequência, nos modos de dizer do discurso acadêmico, ocorrerá, uma vez que essa constituição implica que os professores em formação estejam em uma relação identitária, ${ }^{2}$ inicialmente, com a língua

${ }^{2}$ Ao falarmos em relação identitária, aqui, mobilizamos o conceito a partir do ponto de vista psicanalítico. De acordo com Nasio (1989, p.101), para Lacan, “[...] o conceito lacaniano de identificação responde a um desafio mais extremo do que o desafio freudiano, já que não se trata mais de dar conta da relação entre dois termos relativamente bem constituídos - um eu determinado identificando-se com um objeto igualmente definido - mas de dar nome a uma relação em que um dos termos cria o outro. [...] a identificação é o nome que serve para designar o nascimento de uma nova instância psíquica, a produção de um novo sujeito. [...] estamos longe do esquema tradicional da identificação compreendida como uma transformação entre dois termos previamente existentes, $A$ transformando-se em $B$, estamos em um esquema muito diferente, o esquema da causação de um desses termos, produzido pelo outro. [...],não apenas a identificação é inconsciente, não apenas significa engendramento, mas ainda e, sobretudo, o sentido do processo é invertido. Em vez de A se transformar em B, [...] é B que produz A. A identificação significa que a coisa com a qual o eu se identifica é a causa do eu. [...] o agente da identificação é o objeto e não mais o eu.". Para efeitos de nossa discussão, tendo em vista o conceito de identificação, aqui exposto, reiteramos que a entrada dos professores em formação na ordem do discurso acadêmico não é algo passível de controle no processo de formação. No entanto, parece-nos que, sem que o professor em formação se deixe captar por esses novos (outros) modos de dizer, sua entrada na ordem do discurso acadêmico pode ficar comprometida, uma vez 
que estudam e, em decorrência, com os assuntos afeitos ao seu ensino. No caso da formação dos professores, tanto de língua portuguesa quanto de língua estrangeira, trata-se de uma tarefa dupla: ao mesmo tempo em que estudam a língua em um processo de aprendizagem da mesma, são impelidos a pensar e se formar, como especialistas, sobre os aspectos teóricos e metodológicos que envolvem o seu ensino.

Nesse sentido, aos professores formadores dos cursos de letras impõe-se uma tarefa desafiadora: proporcionar as condições para que esse processo seja desencadeado para que, a partir dele, seja possível problematizar com os professores em formação o que seria uma relação de implicação com o objeto de trabalho no processo de formação vivenciado em um curso de letras.

Neste capítulo, impusemo-nos a tarefa de elucidar essa discussão a partir da problematização da relação entre um professor de um curso de letras, que ministra a disciplina intitulada "Práticas Discursivas da Academia", e uma aluna em formação. Diante disso, postulamos que um dos aspectos que caracteriza a relação do professor de escrita acadêmica com o professor em formação seria levar em conta que o processo de constituição do aluno em formação em práticas discursivas acadêmicas letradas comporta uma tensão entre as duas partes, o que, a nosso ver, seria a condição para que esse professor em formação nelas se constituísse.

Dizemos isso em função do fato de que a formação intelectual, nesse caso, em nível superior, supõe uma demanda psíquica considerável do aluno em formação. Isso porque, dentre outros aspectos, essa formação implica um contato direto com modos de dizer próprios do discurso acadêmico que colocam esse aluno em contato direto com um estranhamento e uma dificuldade eminentes, dada a história de cada professor em formação de se constituir nesse espaço das práticas discursivas acadêmicas letradas. É com essa realidade que tanto o professor quanto o aluno em formação lidam ao se confrontarem com a tarefa da formação intelectual de um professor de línguas.

Para fins específicos desta discussão, relatamos alguns aspectos que puderam ser notados no percurso de uma aluna em seu processo de formação como professora de língua inglesa em um curso de letras. Enfocaremos os impasses ou as dificuldades vivenciadas pela aluna em formação e pelo professor formador ${ }^{3}$ ao se confrontarem com uma tarefa

que não se torna possível uma relação em que ele seja causado por esses modos de dizer outros.

${ }^{3}$ Esclarecemos que o professor formador coincide com o autor deste capítulo. 
específica relacionada à escrita acadêmica, qual seja, a escrita de uma resenha em língua estrangeira. É preciso dizer que, ao falarmos em impasses, estamos na perspectiva de pensar tanto naqueles da aluna em formação quanto nos do professor formador, uma vez que a tarefa de mobilizar e engajar um aluno em uma atividade intelectual nos afasta do campo das certezas, sendo preciso levar em conta a maneira particular com que cada um se engaja (ou não) nesse processo.

0 curso de letras a que nos referimos prevê em sua grade curricular duas disciplinas específicas em que a escrita acadêmica se faz presente formalmente. Uma no quarto semestre do curso, intitulada Habilidades Integradas em Língua Estrangeira com Ênfase na Escrita e Práticas Discursivas da Academia, sobre a qual fazemos algumas considerações. Nessa disciplina, os alunos devem, de forma muito prática, dedicar-se à escrita acadêmica em língua estrangeira, incluindo aí a escrita de resumos, relatos de pesquisa, resenhas, assim como a participação em atividades acadêmico-orais, tais como a apresentação de comunicações, participação em mesas-redondas, anotações de itens em conferências, dentre outras atividades.

Analisemos, pois, as dificuldades/impasses de uma aluna para produzir uma resenha, em língua estrangeira, que nos parece ilustrativo daquilo que argumentamos sobre a complexidade do processo de entrada nos modos de dizer do discurso acadêmico no espaço discursivo desse curso de letras, um dos lugares privilegiados da formação.

0 relato sobre esses impasses foi obtido a partir de sessões de orientações ocorridas entre o professor formador e a aluna, o que foi registrado, informalmente, pelo professor formador sob a forma de notas de campo que possibilitaram este relato.

\section{A escrita de uma resenha acadêmica: história de um percurso}

A aluna, em questão, deveria escrever uma resenha seguindo as orientações dadas pelo professor ${ }^{4}$. A partir de um assunto escolhido

\footnotetext{
${ }^{4}$ A aluna teve contato com materiais sobre a produção textual na universidade, integrantes da disciplina, os quais forma discutidos em aulas e em sessões individuais de orientação. Dentre os materiais utilizados, destacamos o livro de Motta Roth e Hendges (1989) Produção Textual na Universidade. De forma contextualizada, esse livro procura mostrar as características fundamentais da escrita de gêneros acadêmicos.
} 
pela aluna, ela deveria escrever em língua inglesa a resenha de um texto que dialogasse com um ou mais textos, procurando, dessa forma, ir além das descrições dos conteúdos de ambos os textos, posicionandose frente ao assunto. Essas foram as instruções gerais do trabalho de resenha solicitado, tendo em vista que o professor havia trabalhado com explicações e exemplos de vários tipos de resenha de textos acadêmicos, mostrando a sua função para o trabalho acadêmico. Nesse sentido, o professor enfatizou que o gênero resenha deveria conter minimamente quatro partes: uma introdução do assunto, uma descrição da perspectiva sob a qual o autor desenvolveu aquele determinado tema, uma apreciação do resenhista mediante suas opções teóricas e, finalmente, uma avaliação crítica do trabalho apreciado em que houvesse uma recomendação ou não do texto resenhado aos leitores.

Ressaltamos que a escrita dessa resenha está inserida dentro do conteúdo programático das disciplinas aludidas anteriormente (Habilidades Integradas em Língua Estrangeira com Ênfase na Escrita e Práticas Discursivas da Academia). Em outras palavras, houve um trabalho de preparação sobre esse gênero de escrita solicitado e trabalhado com os alunos previamente.

Passemos, agora, ao relato das dificuldades/impasses vivenciados pela aluna nesse processo de escrita da resenha solicitada na disciplina.

Como o tema deveria ser escolhido pela aluna, um primeiro conflito se apresentou, relativo ao tema a ser escolhido, uma vez que, para isso, seria preciso que ela, a aluna, estivesse identificada com os próprios temas tratados em seu curso de letras, locus de sua formação acadêmico-profissional. Referimo-nos, aqui, a algo que dela o dissesse, que lhe interessasse.

Essa fase do trabalho de escrita da aluna remete-nos a uma realidade dos cursos de letras em que, via de regra, acontece com muita frequência. Há alunos que parecem não se identificar com o curso, apesar de afirmarem, por vezes, que gostam, por exemplo, das línguas que estudam ou mesmo que entraram no curso para aprender a língua inglesa. 0 que ocorre, no entanto, é que esses dizeres nem sempre são sustentados, o que pode ser constatado ao serem perguntados, por exemplo, quanto tempo se dedicam aos estudos dessa língua em seu cotidiano ou mesmo quais os investimentos feitos em materiais didáticos tais como gramáticas, dicionários e tantos outros que, potencialmente, demonstrariam que essa língua e, portanto, a sua aprendizagem, ocupa um lugar concreto de interesse na 
agenda de tarefas desses alunos que seria própria daqueles que estudam uma língua estrangeira, condição sem a qual essa aprendizagem poderia estar fadada ao fracasso.

Em geral, as respostas a essas perguntas são evasivas e demonstram que nem sempre aprender essa língua estrangeira não é algo que está incluído na ordem do desejo desses alunos. ${ }^{5}$

Muitos alunos são, assim, constituídos por um imaginário que lhes permite construir concepções sobre aprender uma língua estrangeira que advém de várias instâncias da sociedade e que reforçam a ideia de que aprender uma língua estrangeira seria algo fácil, sem exigências significativas dos aprendizes. Não se coloca, nessa equação, portanto, que se trata, justamente do contrário: a aprendizagem de uma língua demanda muito psiquicamente de alguém que se lança, ou melhor dizendo, que se impõe o desafio de aprender e se tornar professor de uma determinada língua estrangeira. ${ }^{6}$

A escolha do tema, ainda, proporciona, uma outra dimensão desse conflito que podemos tratar da seguinte forma. Como vimos argumentando, ler e escrever no espaço discursivo-acadêmico não se equivale a ler e a escrever qualquer coisa. A escolha de um tema para a escrita de uma

\footnotetext{
${ }^{5}$ Sobre o desejo de aprender uma língua estrangeira, Prasse (1997, p.73) trabalha com a hipótese, segundo a qual "o desejo de aprender, de saber falar uma língua, se alimenta de duas fontes aparentes que, no fundo, não passam de uma só: inveja dos bens e da maneira como gozam os outros, e inquietação de não estar no lugar necessário, de não poder encontrar seu próprio lugar na língua materna, uma interdição necessária para situar o desejo (o que pode se exprimir como uma inibição para falar ou escrever, por exemplo) (...) o desejo de aprender uma língua estrangeira (é claro, não falo da necessidade constituída por circunstâncias exteriores, como a emigração, por exemplo) pode ser um desejo de ter escolha, de poder escolher a lei, as regras e muitas vezes o mestre de nosso gozo. É o desejo de ser livre para escolher uma ordem na qual "se exprimir", de impor-se a uma ordem por um ato voluntário, aprender, enfim, como se deve falar corretamente e gozar com isso." A reflexão de Prasse parece-nos importante porque não raro vemos alunos em cursos de letras em cuja relação com as línguas estrangeiras que estudam não é possível identificar essa dimensão do desejo e do gozo de que nos fala autora. Em decorrência, a relação desses alunos com o saber específico da língua estrangeira que estudam não parece ser uma relação de constituição nessa língua, mas sim aquela em que a língua permanece como objeto a ser adquirido racionalmente.

${ }^{6}$ Sobre a demanda psíquica requerida de alguém que se dispõe a aprender uma língua estrangeira e,em nosso caso, tornar-se professor dessa língua, o artigo de Revuz (2006) é elucidativo. A autora discute a questão, trabalhando com a idéia de que "aprender uma língua estrangeira é sempre, um pouco, tornar-se um outro" (p.227).
} 
resenha demanda que o aluno se constitua pela via de dizeres que encerram discursos específicos. Em outras palavras, ler e escrever, no espaço discursivo-acadêmico, implica posicionar-se a partir de um lugar teórico com o qual se identifica. Isso é altamente complexo porque está em jogo perceber que esse engajamento em modos de dizer diferentes exige distinguir, necessariamente, as teorias umas das outras. Trata-se, a nosso ver, de uma oportunidade que os alunos têm de experimentar que as diversas teorias sobre o ensino e a aprendizagem de línguas não constituem o objeto de estudo da mesma forma. Eis aí a complexidade do processo que precisa ser vivido/experimentado.

No caso que trazemos, aqui, a aluna escolheu um tema com o qual parecia se identificar, o ensino de língua portuguesa como língua estrangeira, dado que ela estava à época engajada com o mesmo tema para a realização de um curso para alunos estrangeiros, registrados em programas de intercâmbio, em sua universidade.

A escrita do texto propriamente dito provocou o enfrentamentoestranhamento com esse outro modo de dizer específico. 0 primeiro desafio da aluna foi enfrentar o fato de que seu texto estava muito próximo do texto primeiro, ou seja, ela, em suas orientações com o professor formador, sempre ouvia a sua recomendação de que, mesmo se tratando de uma resenha, deveria haver um limite de reprodução e/ou descrição do texto primeiro, sob pena de não ser possível que sua posição de resenhista fosse exercida e ela pudesse se responsabilizar por aquele texto específico denominado resenha. Esse enfrentamento-estranhamento, tal qual administrado pelo professor formador, fez surgir para a aluna uma possibilidade de entender que deveria haver um equilíbrio nas descrições exigidas pelo texto de uma resenha.

Diante desse primeiro impasse, o professor formador não perdeu a chance de adentrar um pouco mais no texto da aluna, discutindo, agora, o lugar da reprodução quando se escreve um texto acadêmico. Argumentou o professor que, de certa forma, a aluna parecia se "colar" no autor do texto resenhado sem conseguir dizer com suas palavras o seu conteúdo. No entanto, esse comentário do professor não se impôs como sendo da ordem de uma moral, de uma censura que usaria isso para julgar de forma implacável o texto da aluna. Ao contrário, o comentário do professor direcionou-se no sentido de dizer que se tratava de uma fase da produção dos trabalhos acadêmicos pela qual aqueles que estão em processo de entrada 
nesses novos modos de dizer passam. Esse é um dos pontos fundamentais que podem marcar uma diferença no trabalho com a escrita acadêmica de um professor formador para um aluno em formação.

Outros problemas na escrita da resenha foram surgindo na medida em que a tarefa de escrevê-la se apresentava. A aluna, ao iniciar o seu texto, não anunciava o tema da resenha, não informando ao leitor sobre qual seria o texto primeiro com o qual estava dialogando, o que comprometia a clareza de seu texto, uma das condições para se atender ao que se quer ao escrever uma resenha.

Ao longo do texto, não havia nenhuma referência ao autor que estava sendo resenhado, assim como a ausência de citações e de referências de acordo com as normas vigentes para a escrita de um texto acadêmico. Havia, ainda, problemas de formatação do texto, o que pôde ser percebido pelo uso equivocado, por exemplo, do parágrafo americano.

0 registro de uso da língua inglesa estava fora dos padrões de formalidade exigidos por um texto acadêmico com marcas de um modo de dizer ainda muito próximo ao da Língua Portuguesa. Esse fato trouxe à tona a natureza da relação do aluno com a língua estrangeira (inglesa), qual seja, uma relação, notadamente, atravessada pela língua materna como um suporte para se estar no espaço discursivo da língua estrangeira. Em outras palavras, a aluna não podia, naquele momento, levar em conta que os modos de dizer algo em uma língua sofrem modificações, por vezes significativas, em uma outra.

Destacamos, nesse momento, que não se trata de apontar defeitos em um trabalho dessa natureza, mas o que mostramos aí são as evidências de como esses detalhes da escrita acadêmica propriamente dita aparecem e devem ser tratados numa perspectiva processual sem que caiamos naquelas máximas, que tanto ouvimos na universidade e em outros ambientes educacionais: ah os alunos não sabem escrever. É nesse sentido que vemos que o trabalho de escrita acadêmica deve ser visto na perspectiva de Riolfi (2003, p.47) quando afirma que se trata de um trabalho de escrita, com a escrita. 0 trabalho de escrita, assim entendido, pode fazer com que aquele que escreve sofra modificações ao voltar ao seu próprio texto, impondo-se a necessidade de (re)escrevê-lo. Essa volta ao próprio texto pode, assim, possibilitar modificações em quem escreve. De acordo com a autora: 
A - É o sujeito quem trabalha efetuando deliberadamente diversas operações discursivas para a construção de uma ficcionalização através da qual o processo de construção do texto escrito fica escondido e velado para o leitor. B - É a escrita quem, uma vez depositada grosseiramente no suporte, trabalha no sujeito, fazendo com que ele mude de posição com relação ao próprio texto e possa, sobre ele, exercer um trabalho.

Para que isso aconteça, a intervenção de um professor, constituído em modos de dizer acadêmicos, pode ajudar um aluno a ver que ele também pode nesses modos se constituir, uma vez que por eles pode ser afetado.

Um outro impasse da aluna nesse processo de escrita da resenha foi a percepção de que havia uma limitação em fazer uma escolha teórica. Contemos o fato: uma das observações feitas pelo professor sobre a resenha escrita pela aluna referiu-se a sua escolha teórica face ao que o artigo preconizava sobre o tema: Ensino de língua portuguesa como língua estrangeira. Ao ser questionada, então, pelo professor, sobre sua concordância com a postura sobre o artigo frente ao tema em estudo, a aluna limitou-se a dar opiniões marcadamente impressionistas, tais como, "acho isso ou aquilo" e aí, quando questionada sobre o fato de que seus argumentos se constituíam em opiniões vagas sobre o assunto, em nível do senso comum,surgiu a necessidade de dizer que em uma resenha, ao nos reportarmos de forma crítica a uma postura teórica usada em um artigo, nós assim o fazemos reconhecendo ou não os méritos de uma teoria, ao mesmo tempo em que nos posicionamos frente ao assunto tratado, também por um viés teórico com o qual nos identificamos. Essa foi a condição mínima apresentada à aluna como ponto de partida para que uma posição sua pudesse ser sustentada em seu texto.

De modo específico, a aluna deparou-se com o fato de que o artigo escolhido para a resenha discutia o assunto valendo-se de uma abordagem de ensino comunicativa, o que implicava determinadas concepções sobre o que seria a língua, a linguagem, o ensinar e o aprender que não constituíam, para ela, pontos pacíficos. Em uma outra disciplina que cursava, Linguística Aplicada, as abordagens de ensino de línguas estrangeiras estavam em discussão e, segundo ela, havia divergências entre uma abordagem e outra.

A aluna foi tocada, assim, pelo fato de que ela deveria ler a aprofundar sobre as outras abordagens sobre o ensino de línguas estrangeiras; 
percebeu que não seria suficiente apenas um artigo sobre o assunto para que ela se posicionasse e pudesse, de alguma forma, sustentar uma posição frente ao artigo lido. Em uma palavra, a aluna se deparou com a falta que gera perguntas para as quais só podemos ter respostas provisórias que nos fazem confrontar posições diferentes. Ela tinha dúvidas sobre o alcance das abordagens sobre o ensino e a aprendizagem de línguas que, por um bom tempo, se apresentavam como um não sentido que, por mais que se tentasse contornar, mais se impunha a necessidade de a ele dar respostas, ainda que provisórias, conforme aludimos anteriormente. Ela se sentiu, a nosso ver, convocada a responder a uma questão acadêmica.

E, diante disso, a aluna foi ao encontro de outros artigos, outras leituras. Posicionou-se, ainda, a aluna diferentemente frente ao curso de Linguística Aplicada que ela também estava cursando à época da escrita da resenha. Notamos que essa falta, nesse caso teórica, vivenciada pela aluna, passou a ser encarada com outros olhares ao se dar conta de que a disciplina Linguística Aplicada estava justamente problematizando algo que era de fundamental importância para sua discussão sobre o ensino e a aprendizagem de português como língua estrangeira.

Em outras palavras, parece ter havido aí uma possibilidade de deslocamento de uma posição discursiva não implicada com as questões afeitas, próprias à sua formação, para uma outra que, por se caracterizar por uma implicação, abriu para a possibilidade de dificuldades relativas à formação e, em decorrência, à entrada na ordem do discurso acadêmico naquilo que concerne à escrita acadêmica em língua estrangeira.

Esse foi o primeiro indício de que a atividade, no caso dessa aluna especificamente, deixou de ser meramente uma atividade escolar para se configurar em algo que pudesse ajudá-la a entrar na ordem do discurso acadêmico, o que, por sua vez, abriu a possibilidade de que ele experimentasse uma escrita acadêmica singular, algo de si estaria ali presente e, em decorrência, uma responsabilidade enunciativa, já que igualmente se abriu a possibilidade de, por sua palavra, se responsabilizar.

E isso está desprovido de um compromisso prévio com qualquer conteúdo, entenda-se, aqui, coerção a uma escolha teórica x ou y, o que comumente vemos acontecer nos cursos de letras, atualmente. Por vezes, o professor formador insistiu no fato de que, naquele momento, não era a sua posição teórica que estava em jogo, mas sim a oportunidade de a aluna levar a termo seu processo de distinção de abordagens teóricas que lhe 
possibilitaria, potencialmente, fazer distinções entre as várias abordagens possíveis sobre o tema de sua resenha.

\section{Considerações finais}

0 percurso dessa aluna, descrito, aqui, possibilita-nos pensar que esse processo de entrada da aluna na ordem do discurso acadêmico, no que diz respeito à escrita, deve ser pensado em sua relação com o professor formador.

Isso porque nesse percurso de escrita de uma resenha acadêmica parece haver um encontro com o não sentido. Mesmo tendo sido faladas e trabalhadas as características de escrita de uma resenha, a aluna, em um primeiro momento, não conseguiu fazer sentido do que precisava fazer para realizar a tarefa de escrever. Deparou-se, assim, com uma diferença radical entre o seu modo de dizer e aquele que lhe era solicitado.

Viveu, desse modo, um confronto que, nesse caso, é constitutivo do processo. Angustiou-se, colocando o corpo em jogo nessa entrada, o que foi visto por sua expressão carregada a cada momento em que o professor acusava alguma impropriedade em seu texto que não condizia com as expectativas de escrita de uma resenha acadêmica.

Énesse sentido que julgamos que a relação com o professor formador pode ser fundamental para algum êxito que se pretenda nesse processo, uma vez que ele pode mediar a tensão produzida entre os modos de dizer da aluna e aqueles que o discurso acadêmico impõe, possibilitando que as dificuldades/impasses vividos pelos alunos, característicos da entrada na ordem do discurso acadêmico, possam ter um destino produtivo.

Isso pôde ser notado, inicialmente, porque o professor se ocupou da aluna provocando-a e, em decorrência, fazendo-a ver seus limites. Notemos que é o professor quem aponta as falhas da escrita da aluna, é ele quem aponta a pertinência ou não da escrita, ou seja, ele funciona como alguém que exerce a autoridade de professor. Ele, assim o faz, porque está constituído desse modo de dizer acadêmico, o que possibilita a aluna também nele se constituir, se dizer.

Ao assumir essa posição de implicação frente a aluna e sua formação, o professor não tinha a priori a garantia de que a aluna reconhecesse nele uma figura de autoridade em quem pudesse se mirar e seguir adiante com sua empreitada específica rumo à escrita de sua resenha. Ela, porém, não 
o faz. Enfrenta a situação e escreve a sua resenha. 0 contrário também poderia ter ocorrido. Isso quer dizer que a aluna reconheceu no professor um sujeito suposto saber, aquele em quem pôde depositar confiança porque, de alguma forma, ele saberia o que seria a sua necessidade de aprendizagem.

No que concerne ao professor, vemos que essa operação só se tornou possível porque a aluna está na ordem do seu desejo. Fazer com que a aluna pudesse experimentar o que é escrever uma resenha acadêmica foi algo sobre o qual valeu a pena trabalhar, valeu a pena debruçar-se. Esse é um aspecto sobre o qual teríamos inúmeros exemplos de professores para quem essa tarefa nunca se impôs e, talvez, nunca se imporá.

Nesse caso específico, o professor se ocupou dessa aluna fazendo com que uma tensão, conforme aludimos anteriormente, fosse produzida entre aquilo que constituía os seus modos de dizer e aquilo que constitui os modos de dizer de uma resenha. Para isso, foi preciso enfrentar seus limites, os impasses enfrentados a cada momento da escrita.

A atuação do professor se faz relevante nesse processo porque, ao tomar a palavra e endereçá-la à aluna, ele o faz a partir das exigências que a entrada na ordem do discurso acadêmico demanda do universitário. Sustenta, assim, sua posição discursivo-enunciativa, possibilitando que a aluna entre no jogo discursivo da demanda específica da escrita acadêmica. Essa entrada só se torna possível porque ao sustentar sua palavra, o professor faz com que aquilo que é da ordem da falta, se imponha à aluna como condição para se enfrentar essa entrada.

Essa tomada da palavra pelo sujeito que, a partir de uma posição discursivo-enunciativa, pode sustentar aquilo que é da ordem de seu desejo, remete-nos à máxima lacaniana, segundo a qual "pela nossa posição de sujeito, somos todos sempre responsáveis" (Lacan, 1998, p.873).

A angústia lacaniana é uma angústia produtora - produz o objetocausa. É o motor da análise e cabe ao analista manejar sua rotação. "O analista é um radar de angústia”, diz Forbes. Com efeito, Lacan a toma como termômetro a ser utilizado pelos psicanalistas: "Sentir o que o sujeito pode suportar de angústia os põe à prova a todo instante" (Lacan, 2005, p.13) A angústia é um parâmetro da direção do tratamento. A experiência analítica é minha referência essencial (idem, p.25). O Seminário X, de Lacan, mantém sua atualidade em relação ao desbussolamento do homem contemporâneo. Viver no mundo globalizado é saber viver com a angústia. Passa-se a uma clínica além da castração, uma clínica voltada a suportar 
a qualidade, o melhor de mim, que não pode se inscrever na civilização, já que esta pasteuriza. Uma clínica sem necessidade da compreensão (Forbes, 2005). Ao não revestir a perda e promover a invenção, a psicanálise é constitutiva de uma ética para nosso tempo.

\section{Referências}

FOUCAULT, M. A ordem do discurso. Trad. de Laura Fraga de Almeida Sampaio. São Paulo, Edições Loyola, 1971.

GEE, J. P. Social linguistics and literacies - ideology in discourses. London, Routledge, 2012.

LACAN, J. A ciência e a verdade. Em Escritos. Rio de Janeiro, Jorge Zahar, 1998.

MOTTA-ROTH e HENDGES. Produção textual na universidade. São Paulo, parábola, 2010.

NASIO, J. D. Lições sobre os 7 conceitos cruciais da psicanálise. Rio de Janeiro, Jorge Zahar, 1989.

PRASSE, J. O desejo das línguas estrangeiras. Revista Internacional, v.1, n.1. Rio de Janeiro, Paris, Nova York, Buenos Aires, 1997.

REVUZ, C. A Língua estrangeira entre o desejo de um outro lugar e o risco do exílio. Trad. de S. Serrani-Infante. Em SIGNORINI (org.) Língua(gem) e Identidade. Campinas: Mercado de Letras, 2006.

RIOLFI, C. Ensinar a escrever: considerações sobre a especificidade do trabalho da escrita. Em Leitura: Teoria e Prática - Associação de Leitura do Brasil, v.21, n.340, Campinas, 2003. 


\section{Escrit(ur)a acadêmica: inscrição de si no discurso universitário-científico}

Marluza T. da Rosa

A escrita acadêmica tem sido o alvo de diversas problematizações e é vista como um dos grandes desafios de nossas universidades contemporaneamente. Objeto dos estudos sobre gêneros textuais/ discursivos e sobre os novos letramentos (Fiad, 2011), a escrita na universidade assume um lugar de destaque dentro dessa instituição, possibilitando a solidificação de um círculo de pesquisas que se dedica ao chamado letramento acadêmico (Bonini; Figueiredo, 2010). Além disso, a escrita científica tem sido o foco de diversos cursos e workshops de caráter instrumental, presenciais e a distância ${ }^{1}$, com vistas a familiarizar os estudantes e futuros pesquisadores com as exigências desse outro gênero ou desse novo universo de sentidos. Cabe ainda mencionar os trabalhos que visam a questionar seus "usos e abusos" (Pereira, 2013) ou, por outro lado, os que se dedicam a compreender o mal-estar subjetivo causado por essa prática (Uyeno, 2010).

\footnotetext{
${ }^{1}$ Conferir, por exemplo, o site Escrita Científica, que se atribui o objetivo de "qualificar cientistas, pesquisadores e alunos de pós-graduação para o processamento e produção de Artigos Científicos de Alto Impacto" em<http:// www.escritacientifica.com/pt-BR/>. Acesso em: 10 maio 2015. Cf. Pereira, Marcos Villela. A escrita acadêmica - do excessivo ao razoável. Revista Brasileira de Educação, v.18, n.52 jan.-mar., 2013, p.213-244. Disponível em:<http://www. scielo.br/pdf/rbedu/v18n52/13.pdf>. Acesso em: 28 maio 2015.
} 
Nessas diferentes pesquisas, escrita acadêmica, escrita científica, escrita universitária e escrita na universidade são sintagmas oscilantes, que parecem apontar para a mesma prática, a de escrever a partir de determinado domínio, de um dado lugar de produção de saberes. Mas trataríamos da mesma "coisa", apenas com diferentes nomes? Em que medida a inserção da escrita no ambiente acadêmico significa-a diferentemente? Não é difícil percebermos que essas múltiplas formas de se referir a esse fazer visam, prioritariamente, a distingui-lo da escrita escolar, da escrita jornalística, da escrita cotidiana. Instaura-se, assim, em um primeiro tempo, uma diferenciação entre a escrita "acadêmica", com seus graus de eruditismo, ou a escrita "científica", com sua clareza e objetividade, e a escrita ordinária, simples, feita por pessoas comuns. Estabelece-se, portanto, uma hierarquia.

Tal diferenciação ainda vai além da simples nomenclatura, porque obedece a uma ordem que se exerce principalmente no âmbito formal e influencia a imagem de quem escreve por meio daquilo que se escreve. Não se trata, pois, de um sintagma qualquer, uma vez que a justaposição de "científica" ou "acadêmica" ao termo escrita (para falarmos apenas dessas duas aposições) destaca essa prática das demais, situando-a em outras condições de produção, regradas pela ciência, pela universidade, pela academia, pelo discurso científico, com todos os efeitos de sentido e o imaginário que os circundam. Essa ordem de discurso seleciona, secciona, regulariza suas práticas e as direciona a fins específicos, que são os seus e não necessariamente os das subjetividades aí inscritas. Pelo contrário, ela produz modos de subjetivação adequados a seu funcionamento, objetivando o sujeito, seja por meio da racionalização e do status científico, seja pela relação de dependência entre esse status e sua produção.

Este trabalho toma como ponto de partida, não o escrever enquanto processo de imprimir signos em um espaço retangular e vazio, tampouco a escrita como resultado desse processo que lhe seria anterior, mas o dizer sobre a escrita, que se caracteriza como uma escritura, "inscrição que deixa uma marca" (Derrida, 2001a, p.41), e tem o propósito de compreender de que modo a prática da escrita se insere na economia do que temos chamado de discurso universitário-científico (Da Rosa, 2013). Esta reflexão se organiza de modo a possibilitar, primeiramente, um percurso pela noção de discurso universitário-científico; em seguida, um olhar para o modo como procedemos na constituição e na análise do corpus; e, por 
fim, uma reflexão sobre os resultados da análise pela ótica da relação entre a escrita e a inscrição do pesquisador na ordem do discurso em questão.

\section{Em torno da escrit(ur)a no discurso universitário-científico}

O olhar para a escrit(ur)a no discurso universitário-científico consiste em uma das vias de interpretação possibilitadas por nossa pesquisa de doutorado, na qual estudamos a influência desse discurso na constituição identitária do pesquisador em formação. De caráter inacabado, como se caracteriza todo texto, enquanto "sistema de remissões a outros textos", nos termos de Foucault (2009), ou como "rede de remessas textuais", nas palavras de Derrida (2001b), nossa pesquisa dialoga com as discussões que convergem para a problematização da (re)estruturação do ensino superior e do lugar, assim como do papel, da universidade atualmente. É como parte constitutiva desse cenário que abordamos a problemática da escrita, seja enquanto prática socialdiscursiva, seja como inscrição de si (escritura), o que marca um duplo movimento, ao mesmo tempo, de retorno a e de distanciamento de nosso trabalho anterior. Neste, caracterizamos o discurso universitário-científico com base em seu funcionamento intervalar, entre a ciência feita e a ciência em desenvolvimento, ancorado em uma memória discursiva que, por sua vez, remonta a diferentes domínios de sentido, como o discurso da ciência, o da universidade, o de divulgação científica, o do senso-comum; domínios estes atravessados pela lógica dominante contemporaneamente, a do discurso capitalista. Além disso, buscamos situar a

problemática do/sobre o discurso científico na esfera acadêmica, local em que esse discurso pode ser entrevisto tanto como produto, quanto como processo. Pensamos, assim, no discurso universitário-científico como um possível lugar de afirmação e de contestação do discurso da ciência (Da Rosa, 2013, p.89, grifo nosso).

Não é difícil compreendermos como a escrita, principalmente a chamada escrita científica, contribui para a afirmação e a permanência desse discurso hegemônico, em seu desejo de neutralidade e de objetividade, em seu caráter assertivo e racional, aspectos frequentemente de- 
mandados nos textos acadêmicos. Trata-se de uma escrita que se quer superpotente para que possa sustentar de modo adequado um discurso oni(m)potente como o científico, o qual dela depende para que não se veja facilmente seu caráter faltoso e equívoco. É enquanto escrita formalizada, matematizada, "não abstrata, mas puramente lógica" (Lacan, 1992, p.151), ancorada em axiomas e regras, que o discurso da ciência se instaura e é na escrita dita científica que encontra sua principal mantenedora, pelo menos na universidade.

Já para que possamos entender o viés da contestação, é de outra escrita que devemos tratar, a de si, que concerne menos à ciência do que ao sujeito que ela dissimula. A abordagem dessa outra escrita, ou melhor, dessa escritura, foi possível por meio da escuta do dizer dos pesquisadores em formação, participantes de nossa pesquisa. Esse dizer pode ser compreendido enquanto um elemento que permite trabalhar com a falta que está na base do discurso da ciência, pois a própria construção da designação discurso universitário-científico autoriza um movimento do olhar que parte da base, dos bastidores, em direção à estrutura, à cena montada e mostrada, ao mesmo tempo, unindo-os, pois bastidores e cena coexistem.

Para a análise do funcionamento do discurso universitáriocientífico, tomamo-lo, inicialmente, como uma rede de práticas sociais, cuja ordem restringe, limita ou autoriza aquilo que pode e deve ser dito (Foucault, 2001; 2009), conforme pontuamos já na introdução deste trabalho. Essa rede se ancora em uma memória que atualiza traços de outros discursos, como o da ciência (nesse caso). Porém, como argumenta Foucault $(2001 ; 2009)$, conceber o discurso apenas como ordem ou darlhe um caráter linear e continuamente infinito faz com que se esqueça de sua dimensão de acaso, de dispersão e de acontecimento, que produzem sentidos inesperados, os quais podem ir à contracorrente daqueles já-dados. É preciso, pois, estar atento a essas rupturas múltiplas que deslocam ou potencializam o deslocamento dos sentidos.

Entendemos que o discurso universitário-científico pode se constituir como um desses possíveis pontos de ruptura, enquanto domínio de produção de conhecimento, mas, sobretudo, de saber, pois, para Foucault (2010, p.28), "o saber não é feito para compreender, ele é feito para cortar". Essa concepção de saber pode ser aproximada à visão psicanalítica, quando Lacan (1998, p.883) enfatiza, por meio de uma pergunta retórica, ser "preciso dizer que temos de conhecer outros saberes que não o da 
ciência, quando temos que tratar da pulsão epistemológica", pois Foucault (2013, p.306) afirma, ainda, empregar "a palavra 'saber' estabelecendo uma distinção com 'conhecimento'”, sendo o saber visto como "um processo pelo qual o sujeito sofre uma modificação por aquilo mesmo que ele conhece, ou, antes, por ocasião do trabalho que efetua para conhecer".

A designação discurso universitário-científico possibilita, assim, que se faça não só dialogar com esses autores em torno da questão do saber, mas também operar a noção lacaniana de discurso, pois nos reenvia a uma de suas quatro modalidades do laço social: o Discurso Universitário. Para Lacan (1992), esse discurso só pode se articular a partir do Discurso do Mestre (da lei, da norma), função desempenhada, em nossos dias, pela ciência, cujo modelo é assumido e reforçado pela universidade, a partir de sua secularização e do advento da ciência moderna. Ainda segundo o autor, uma das características do discurso da ciência é a de não deixar lugar para o homem, logo, é possível observarmos que, ao assumir um modelo científico, a universidade também relega seus integrantes (estudantes, pesquisadores) ao lugar de objeto ou, talvez, a uma promessa de lugar, um $a$-lugar ${ }^{2}$. Além disso, nesse domínio, ao imperativo a tudo saber, que obedece à "fantasia de um saber totalidade", ainda em termos lacanianos (1992, p.31), aliam-se os ideais do consumo, do mercado e do desejo - enquanto desejo de objetos e não do desejo do outro -, constitutivos do Discurso Capitalista - uma "nova modalidade do Discurso do Mestre" (Quinet, 2002, p.33) -, o que tende a resultar em uma mercantilização cada vez maior da produção científica ${ }^{3}$.

Contudo, dado o momento histórico-social contemporâneo, Latour (1995, p.76) se questiona se seria possível falarmos de uma "ciência não capitalista", ou seja, que pudesse ser feita "fora dessa rede de produção desenfreada de enunciados novos". Ainda que não respondamos a essa pergunta, parece-nos que é nessa rede que se insere a escrita acadêmica, ou melhor, é nessa rede que tal escrita insere o pesquisador, produzido como modo de subjetivação que sinaliza a tensão entre a lei de tudo saber, a qual demanda que sempre se produza algo, a foraclusão da dimensão subjetiva desse discurso e, ao mesmo tempo, a injunção para que aí se instaure um "sujeito da ciência" (Lacan, 1998, p.98-99).

\footnotetext{
${ }^{2}$ Referimo-nos a um $a$-lugar, devido ao lugar de objeto (a) que o sujeito assume no discurso universitário da ciência, tratado pelo saber, segundo Quinet (2002), além de explorarmos a homofonia com há-lugar, enquanto promessa.

${ }^{3}$ A esse respeito, conferir Latour (1995) e Lander (2008).
} 
Como sabemos, é sobre a concepção cartesiana de sujeito que se funda essa designação, a qual, de acordo com Lopes (2008, p.250), "nomeia o sujeito cujo modo de constituição é determinado pelo advento da ciência enquanto moderna". Trata-se, assim, de um sujeito produzido pelo discurso da ciência e potencializado no discurso universitáriocientífico. Lembramos que é sobre essa concepção que trabalhamos, não para afirmá-la, mas para subvertê-la, pois, neste estudo, relacionamos a noção de sujeito à de ipseidade, a qual não se define pela intencionalidade do (dizer) "eu penso" nem pela causalidade do pensar.

Frente aos dizeres que analisaremos, a cada vez que escutarmos "eu", devemos fazer trabalhar a divisão lacaniana: "penso: 'logo existo"” (Lacan, 1998, p.879), na qual não se pode afirmar que se trata do mesmo "eu" (je/moi) em "penso" e em "existo". Há uma divisão (formalizada, na reescrita lacaniana do cogito, pelos dois pontos), que nos assegura que o ser/existir não está do mesmo lado do pensar, mas no daquilo que é dito (marcado, aqui, pelas aspas simples). Assim, o eu que pensa e que diz, sujeito da consciência, não equivale ao sujeito do inconsciente nem ao da enunciação $0^{4}$ (voltaremos a esse ponto).

Além de marcar essa descontinuidade pela divisão, na formulação lacaniana, o elemento que indica causalidade, "logo", não está do lado do "eu" que pensa, o que permite afirmar que este não está ligado à causa, mas se constitui como efeito. Nos termos de Mendelsohn (2010), essa formulação marca o retorno de Lacan a Aristóteles, para situar o estatuto da verdade na ciência enquanto causa formal, pois

A verdade toma forma na ciência na medida em que esta nomeia, classifica e define tudo o que existe [...]. Quanto à psicanálise, ela teria uma outra relação com a verdade, porque acentua seu papel de causa material: das quatro causas aristotélicas, é a mais inacessível, a menos conhecível, a mais opaca, embora seja a mais presente (Mendelsohn, 2010, p.156). ${ }^{5}$

\footnotetext{
${ }^{4}$ Para um diálogo mais estreito com o pensamento de Foucault, lembramos que, segundo o autor, o discurso "não é a manifestação, majestosamente desenvolvida, de um sujeito que pensa, que conhece, e que o diz: é, ao contrário, um conjunto em que podem ser determinadas a dispersão do sujeito e sua descontinuidade em relação a si mesmo" (Foucault, 2009, p.61).

${ }^{5}$ Tradução nossa para: «La vérité trouve forme dans la science dans la mesure où celle-ci fait œuvre de nommer, classer et définir tout ce qui est [...] La psychanalyse aurait quant à elle un autre rapport à la vérité, parce qu'elle en accentue le rôle de
} 
Herdeira do cartesianismo e veiculando sua verdade enquanto causa formal, a ciência, conforme Milán-Ramos (2007, p.21), não quer saber do saber inconsciente, ancorando-se em variados "procedimentos de cancelamento do sujeito". Nesse discurso, como pontuamos em nosso trabalho de tese, não somente as dimensões da enunciação e do processo de produção do conhecimento tendem a ser silenciadas, mas também o desejo investido nesse fazer, de modo que os traços mais intrínsecos do sujeito do inconsciente são relegados ao esquecimento no ideal de sujeito da ciência, o qual se apresenta como desprovido de falta e, consequentemente, de desejo.

Na síntese dos matemas lacanianos oferecida por Passone (2013), lemos que:

todo laço social que trata o outro como escravo, ou um saber-produzir, insere-se no discurso do mestre; todo discurso que trata o outro como objeto retrata o discurso universitário; e todo laço social que trata o outro como consumidor e objeto de consumo inscreve-se na lógica do mestre moderno, o capitalismo (Passone, 2013, p.58).

Essas definições podem nos auxiliar a refletir sobre o modo de operação do discurso universitário-científico, contanto que não as tomemos isoladamente. Experimentemos, então, conceber uma economia discursiva que as articule, ou seja, um discurso no qual o outro ocupe tanto o lugar de quem executa um trabalho, um saber-produzir, quanto o de quem é, por meio desse trabalho, objetificado ou transformado em sujeito produtivo, que, como tal, deve (se) consumir. Ora, se nos perguntarmos de que modo a escrita acadêmica se insere nessa maquinaria, podemos facilmente perceber que ela é o que se produz, o que se é instado a produzir; de modo mais amplo, porque a ciência (ou, diríamos, o ideal de ciência) é vista como uma escrita com linguagem própria, segundo Koyré (1991), de modo mais pontual, porque, como veremos nos recortes analisados, escrita e publicação, assim como publicação e produção, funcionam em uma relação de quase-sinonímia no discurso universitário-científico. Escrever é produzir.

Ainda de acordo com Mendelsohn (2010), é na causa material, rejeitada pela ciência, que Lacan sustenta a linguagem, enquanto estrutura

cause matérielle: des quatre causes aristotéliciennes, c'est la plus inaccessible, la moins connaissable, la plus opaque, bien que la plus présente». 
simbólica - o que nos permite tratar de sua opacidade, de sua intangibilidade, uma vez que esta transgride os limites do signo, não nos oferecendo um significado já-dado, atrelado ao significante ${ }^{6}-$, bem como o "nó" que causa e divide o sujeito e que o deixa "às voltas com a incompletude e com a experiência que dela decorre, difícil de sustentar, de uma alteridade interna, de uma 'extimidade"'7 (Mendelsohn, 2010, p.157). Essa concepção de linguagem faz falhar a pretensão totalizante, porque supostamente inequívoca, do discurso e da escrita científica. Tal concepção de sujeito também é cara a muitos dos estudiosos que se vinculam, de um modo ou de outro, aos estudos da linguagem a partir de uma escrita de si, pois, como sabemos, o sujeito não se resume ao eu estável que enuncia, sendo sempre outro/estrangeiro a si mesmo (Kristeva, 1994; Ricoeur, 1990) e funcionando pelo adiamento, na différance, enquanto "impressão que insiste através do sentimento instável de uma figura móbil, de um esquema ou de um processo in-finito ou indefinido" (Derrida, 2001a, p.44).

Derrida (2001a) se refere com tais palavras à noção de arquivo. Contudo, deslocamo-las para circunscrevermos a noção de sujeito em seus estudos, não só porque os chamados "quase-conceitos" derridianos funcionam em rede, eventualmente se substituindo de modo oblíquo e não-sinonímico, mas também porque há um elo perceptível, nas próprias palavras do autor, entre ambas as noções, já que a ideia de instabilidade, mobilizada para falar de arquivo, perpassa também a concepção de sujeito esboçada a seguir, a partir das teses freudianas. Ao abordar a contribuição destas para seu pensamento, o filósofo enfatiza que,

em lugar de um sujeito consciente de si mesmo, respondendo soberanamente por si mesmo perante a lei, pode-se utilizar a idéia de um "sujeito" dividido, diferenciado, que não seja reduzido a uma intencionalidade consciente e egológica. E de um "sujeito" que instala progressivamente, laboriosamente, sempre imperfeitamente, as condições estabilizadas - quer dizer, não naturais, essencialmente e para sempre instáveis - de sua autonomia: sobre o fundo inesgotável e invencível de uma heteronomia (Derrida; Roudinesco, 2004, p.211, grifos nossos).

\footnotetext{
${ }^{6}$ Segundo Lacan (1998, p.890), "Essa causa material é, propriamente, a forma de incidência do significante como aí eu defino. Pela psicanálise, o significante se define como agindo, antes de mais nada, como separado de sua significação". ${ }^{7}$ Tradução nossa para: «qui laisse le sujet aux prises avec l'incomplétude et l'expérience qui en découle, difficile à soutenir, d'une altérité interne, d'une 'extimité'».
} 
Chamamos a atenção para o fato de que, embora colocando em jogo uma concepção que se aproxima à noção de sujeito advinda da psicanálise, o autor marca (entre aspas) tal noção, talvez, como uma forma de sinalizar ao leitor que "dispor de um conceito, ter segurança sobre seu tema é supor uma herança fechada e a garantia selada de alguma maneira por esta herança" (Derrida, 2001a, p.47). As aspas, nesse caso, marcam, mais do que a citação de um conceito, a possibilidade de excedê-lo, de ultrapassar seus limites, de diferi-lo. Derrida, a partir do lugar que assume, como amigo da psicanálise, desconfiada noção de sujeito, assim como o faz Foucault. Logo, o que esses autores praticam, no âmbito conceitual, é uma forma de escritura, a favor e contra os textos lidos, deixando neles a marca/impressão (empreinte) de outras leituras.

É também uma escrit(ur)a desconfiada que procuramos desenvolver aqui, pois somos herdeiros do discurso universitário-científico e sujeitos ao paradoxo implicado na herança, que requer não só sua recepção ou afirmação, mas também sua transformação. Tal herança não nos assegura nenhuma garantia, mas permite conceber a (nossa própria) escrita e o discurso científico como inscritos "na ordem do repetível, mas também do transformável ou, até mesmo, do questionável” (Da Rosa, 2013, p.88).

\section{Frente ao corpus ou o fim da escrit(ur)a}

Antes de explorarmos os recortes aqui apresentados, vamos nos deter brevemente no modo como procedemos na constituição do corpus de nosso estudo, o qual foi composto por vinte e uma entrevistas orais semidiretivas. Os participantes, denominados pesquisadores em formação, são estudantes de doutorado em instituições públicas de ensino superior localizadas no Estado de São Paulo e inscritos em diferentes disciplinas vinculadas aos campos das Ciências Humanas, Exatas e Biológicas. A questão proposta aos interlocutores como desencadeadora dos relatos foi a seguinte: "eu sei que você desenvolve um trabalho de pesquisa, vinculado a um curso de doutorado e gostaria que você me falasse sobre como você vê esse processo de formação e como você se vê como pesquisador nesse processo". Supúnhamos que esse falar de si variasse, de acordo com a área em que os participantes estivessem inscritos, o que ocorreu, mas de forma menos significativa do que o esperado, sugerindo que as relações de poder-saber em que estes se inserem estão além ou aquém 
dos domínios disciplinares. Essas entrevistas foram por nós gravadas e transcritas para a finalidade da análise, o que implica no fato de que a transcrição, da qual foram extraídas as sequências aqui analisadas, por consistir em uma transposição da fala à escrita, caracteriza-se como uma outra materialidade, já atravessada pela interpretação, não representando nem reproduzindo a fala.

Os recortes que analisamos neste estudo compreendem a temática da escrit(ur)a no processo de formação para a pesquisa científica. Tais excertos foram formulados por seis participantes, aqui identificados por nomes fictícios. Quando da interlocução, André era pesquisador em formação na área de Linguística Aplicada, Márcia, em Linguística, Paulo, em Química, Raquel, em Ciências Biomédicas, Carolina e Joana, em Ciências Biológicas.

Podemos dizer que, se os excertos que se seguem são marcados por um mal-estar, este não é o da escrita propriamente dita, ou da escrita mal escrita, como já pontuou Uyeno (2010). Nesse caso, entendemos que, se esse mal-estar existe, é concernente ao processo de formação, à necessidade de tomar parte no funcionamento do discurso universitáriocientífico, por meio da escrita acadêmica. Vejamos o primeiro recorte.

R1)eu cumpri os créditos/ agora eu já tô escrevendo né/ mas/ assim/ já/ geralmente é texto mais pontual// a::/ vou participar nesse evento e tal/ vou fechar e depois cê vai incorporando na tua tese né// tentando/ conciliar participação em evento e já o texto da tese/ pra não ficar escrevendo/ porque não é// pra mim não é fácil escrever um parágrafo [riso] (Márcia).

Em R1, podemos notar que a escrita é, inicialmente, (de)negada, pois, apesar de Márcia afirmar que "já" está escrevendo, em uma formulação na qual a marca de antecipação temporal ("já") sinalizaria uma relação harmônica, rápida, sem muitos problemas, essa escrita não parece ser a ideal, como indica o marcador discursivo de contradição ("mas"), pois se trata de textos "pontuais", direcionados e significados como uma forma de ação mais imediata, a de cumprir uma demanda institucional que parece pertencer a uma ordem disciplinar, qual seja, a de dar-a-ver seu trabalho em eventos acadêmicos.

A partir dos moldes do discurso universitário-científico, a interlocutora reformula, de modo hesitante, seu dizer (né/ mas/ assim/ já/ [...]// 
a::/), talvez porque acredita não estar "escrevendo" (em uma dimensão em que escrita apontaria para um processo), mas "produzindo", ou seja, direcionando essa prática a eventos pontuais, por meio de textos unos, fechados. Trata-se de uma escrita que seria não só fragmentada para atender a exigências mais imediatas do discurso universitário-científico, mas também descarnada a priori, posto que é só-depois que essa prática fragmentária "vai [se]incorporando", tomando corpo, na (forma de) tese, como indiciam os marcadores "agora" e "depois". Se há essa demanda imediata, deve haver um modo de satisfazê-la, e é nesse movimento de obediência a uma série linear de etapas (cumprir créditos, ir a eventos, fazer a tese) que o pesquisador em formação se inscreve, desenvolvendo estratégias de conciliação que lhe permitam atender tais solicitações e, ao mesmo tempo, "não ficar escrevendo", uma vez que esta é uma tarefa considerada difícil. Notamos, já nesse primeiro recorte, que a problemática da escrita acadêmica não concerne só ao gesto de escrever, mas à relação conflituosa com seu produto fechado ("texto mais pontual", "texto da tese") e seu direcionamento ao outro: o que se escreve? Para que(m) se escreve?

Podemos dizer que é a partir da injunção a responder com uma escrita que a pesquisadora enuncia o papel que tenta desempenhar nessa ordem, escrevendo sem (se) escrever, já que seu objetivo é o de "não ficar escrevendo". Notamos, nessa formulação, que o verbo "ficar" sugere uma permanência, uma demora que deve ser evitada. Esse efeito de sentido aponta para um modo de subjetivação constituído pelo aqui/agora, adequado ao imediatismo e aparelhado de acordo com o imperativo do discurso capitalista na maquinaria universitária. Em outros termos, se tempo é dinheiro, não se deve desperdiçá-lo. É também sobre a questão do tempo, atrelada à dificuldade com a escrita, pontuadas por Márcia, que André discorre no fragmento a seguir.

R2)eu não venho da área de letras então eu não tenho essa destreza de escrita que a galera tem né// é::: então/ eu/ levo muito mais tempo/releio reescrevo aquilo/ que talvez um aluno que tenha um/ imaginariamente não sei/ uma prática de escrita muito maior que a minha// [...] então eu ainda não tenho uma// uma imagem de um bom escritor ainda/ e [...] falta muito pra eu chegar lá/ né/ e escrever textos bons/ pra serem publicados (André). 
Se, por um lado, Márcia afirma "já" escrever, André argumenta que "ainda" não se sente apto a tal prática, encadeando uma série de escusas, ao afirmar seu não pertencimento à área de Letras, sua falta de prática ou de "destreza", sua necessidade de releitura e de reescrita, o que envolve "muito mais tempo". Pelo que o recorte indica, a imagem de um bom pesquisador estaria ligada à possibilidade de escrever textos bons em pouco tempo, o que, indubitavelmente, indicaria sua eficiência e competência. Essa é, afinal, a imagem que temos de um bom profissional: aquele que faz um bom serviço em pouco tempo (e com baixo custo, poderíamos acrescentar). As escusas de André parecem tentar eximi-lo (ou redimi-lo) de uma culpa por não ser esse "bom escritor", de acordo com os padrões universitário-científicos. Contudo, como destaca Derrida (2004, p.67), "longe de apagar a culpa, longe de levar ao 'sem-falta' ou ao 'sem-defeito', as desculpas acrescentam, engendram e aumentam a culpa. [...] A culpa é, portanto, uma inscrição indelével"na constituição desse sujeito. Além disso, a formulação "falta muito pra eu chegar [lá]", recorrente em outros dizeres do corpus analisado em nossa tese, pode ser atribuída a uma imagem de pesquisador ou, nesse caso, de quem escreve, que

pressupõe a completude, já que, nesse lugar [lá], haveria menos falta. Assim, 'falta muito pra eu chegar nesse status'8 ${ }^{8}$ pode indiciar não só o percurso que precisa ser percorrido, mas também o quão faltoso o pesquisador em formação acredita ser, já que é por haver muita falta ('falta muito [em mim] pra eu chegar nesse status') que este não se considera ainda pesquisador (Da Rosa, 2013, p.145-146, grifos da autora).

É um modo de funcionamento análogo que o dizer em questão mobiliza. Reformulando, ainda uma vez esse dizer, a fim de explorar seus sentidos possíveis, "falta muito para" pode significar que é preciso muito mais tempo ou, então, que falta muito tempo para que se alcance uma boa escrita, nesse caso, sem desconsiderar-se que o tempo, assim como o sujeito, também é faltante. Nesse sentido, não seria de todo falso (embora, talvez, imprudente) afirmarmos que a escrita acadêmica sofre de um mal de ser e de tempo, pois, de acordo com Draï (2006),

${ }^{8}$ São termos de outra participante, Joana, em seu relato. 
o mal-estar na pesquisa científica contemporânea [...] se explica sem dúvida pelo desconhecimento dessas espécies de ritmos, como se uma atividade qualquer do espírito, que se exerça individual ou coletivamente, pudesse ignorar essas fases de latência, ou mesmo de lassidão, em suma, como se o inconsciente não existisse e o espírito humano fosse consciência pura, total, absoluta, inesgotável ${ }^{9}$ (Draï, 2006, p.64).

Esse cancelamento do tempo e do sujeito, que produz o mal-estar no discurso universitário-científico, encontra na escrit(ur)a uma de suas vias de manifestação, reforçado pelo imaginário segundo o qual escrever se caracteriza como um trabalho técnico (que exige "destreza", portanto, agilidade, desenvoltura, treino, adestramento). Desse modo, a escrita não é vista como uma forma de produção de saber, na qual um sujeito se implica e deixa sua marca. Pelo contrário, tal fazer é comumente apresentado como um ato mecânico, e o pesquisador, confrontado com a linguagem que se lhe mostra densa, espessa, não manipulável como um objeto, atribui a si mesmo uma falha, vendo-se como faltante diante da ilusoriamente plena e superpotente escrita da ciência, já que "textos bons" são retomados metonímica e quase-sinonimicamente, no dizer de André, por seu endereçamento ou sua finalidade: "para serem publicados”. É em contraposição a esse fim da escrit(ur)a que se manifesta Joana no excerto seguinte.

R3) eu gosto de aprender coisas novas eu gosto de ensinar coisas mas não em si da publicação/ eu acho muito chato escrever artigo/ ficar sentada na frente do computador não é pra mim/ eu gosto mais de/ de ação de/ eu gosto de ver os resultados/ mas/ a escrita pra mim é ruim// escrever tanto relatório como/ artigo/ pra mim é mais sofrido/ obviamente quando você escreve você/ consegue ver melhor/ os resultados/ mas eu tenho uma dificuldade muito grande que vem/ desde pequena/ com o português/ e línguas em geral/ e isso/ tem/ aí eu tenho uma aversão a ficar sentada pra escrever// então quando eu vou fazer relatório ou escrever um artigo eu tenho que/ demorar um tempo maior porque/ eu não tenho paciência/ eu

\footnotetext{
${ }^{9}$ Tradução nossa para: «Le malaise dans la recherche scientifique contemporaine [...] s'explique sans doute par la méconnaissance de ces sortes de rythmes, comme si une activité quelconque de l'esprit, qu'elle s'exerce individuellement ou collectivement, pouvait ignorer ces phases de latence, ou même de lassitude; bref comme si l'inconscient n'existait pas et que l'esprit humain était conscience pure, totale, absolue, inépuisable».
} 
paro/ tenho que parar/ muitas vezes/ e/ não consigo ficar ali/ prestando atenção/ então fica mais complicado pra mim// mas/ eu acho que publicar/ é uma coisa importante porque/ pro/ mundo conhecer o seu trabalho/ pra conhecer os resultados (Joana).

Observemos que, nesse recorte, trata-se da escrita como mais uma exigência institucional, característica de um processo de formação que possui um lado "bom" (aprender, ensinar, ter resultados) e um lado "ruim" (escrever). Estática, entediante, demorada e sofrida, contrapondo-se à ação presente no ensino/aprendizagem e na relação com os resultados da investigação científica, a escrita não é vista como forma de ensinar ou aprender nem como um resultado possível (exceto pela ressalva: "obviamente quando você escreve você/ consegue ver melhor/ os resultados/ mas", a qual poderia indiciar uma escritura, uma forma de se escrever e de se ver melhor, mas que perde sua força pelo marcador de contraste que a encerra). Ela é, ao contrário, um meio ou uma ferramenta para ver os resultados, para mostrá-los e para se dar-a-ver ao outro ("pro mundo conhecer o seu trabalho"), atuando no efeito de vitrine que sustenta o discurso da ciência (Da Rosa, 2013).

Ademais, a escrita parece ser tomada como forma de re(a)presentar, a posteriori, os resultados obtidos, não os constituindo, mas se descolando destes, descrevendo-os, relatando-os a alguém externo ao processo. É esse endereçamento ao outro (não só o outro sujeito, mas o Outro que se materializa na relação com as línguas) que parece caracterizar um sofrimento, uma dificuldade, uma complicação. Isso porque, se é a escrita que permite ver melhor o trabalho e fazer com que o mundo o veja (e veja também o pesquisador), podemos afirmar que o desconforto, a recusa ou a escusa na relação com a escrita advêm de uma impossibilidade de fazer coincidir a experiência do processo de formação, ou seja, a escrita de si no/ pelo conhecimento, enquanto experiência ou saber, nos termos foucaultianos, com o formato esperado da escrita institucionalizada: "a escrita pra mim é ruim// escrever tanto relatório como/ artigo/ pra mim é mais sofrido". É uma impossibilidade, diríamos, de ajustar esse processo a uma ordem narrativa; dificuldade não apenas de dar contornos à experiência do saber, mas de fazêlo nos moldes de uma escrita depurada, engessada e burocrática.

Frente a esse e aos dizeres anteriores, podemos afirmar que essa problemática não se resume ao conflito particular, consigo mesmo (como acre- 
ditam os interlocutores) ou com a língua. Trata-se, antes, de uma relutância a tomar parte em um modo de funcionamento no qual, segundo Quinet (2002, p.34), "o sujeito dividido como produto da ciência, resto do saber científico, é também aquele que é excluído por ela”. São nesses pequenos traços de si, mostrados, principalmente, na negação e na recusa a escrever (no não gostar) ou na necessidade enfatizada da demora ("eu levo muito mais tempo", segundo André, ou "eu paro/ tenho que parar", nos termos de Joana) que se ancora a economia de uma escritura que funciona enquanto phármakon (Derrida, 2005), remédio e veneno, dentro e contra o discurso universitário-científico; rastro ou inscrição de si que potencializa "um ato de resistência, embora inconsciente: resistência ao anonimato [...], ao silenciamento, ao esquecimento", segundo Coracini (2010, p.27), da dimensão subjetiva. No que concerne a esse aspecto, observemos, a seguir, o dizer de Raquel.

R4)pra mim é muito angustiante/ eu acho assim que nem só pelo fato de publicar/é::/ não é só pelo/ precisar publicar/ meu/ precisar publicar é mais além porque/ pra eu defender eu tenho que tá com o artigo aceito/ então o meu programa já me pressiona a publicar// então pra mim/ eu começo meio que a arrancar os cabelos/ porque eu sou bem desesperada/ sabe/ bem ansiosa/ então eu já começo a pensar/ meu deus/ já tô no segundo ano do doutorado e meu negócio não vai pra frente/ eu tenho que ter resultado/ eu tenho que defender/ eu tenho que publicar (Raquel).

Como é possível assinalar nos termos dessa pesquisadora, o elemento desencadeador do mal-estar não é a necessidade da escrita, tampouco a de torná-la pública, mas a do reconhecimento da validade do que se fez por instâncias inscritas em um âmbito de práticas discursivas específicas (por isso, "precisar publicar é mais além"). O conflito com a escrita advém de uma imposição institucional para que esta seja avaliada e "aceita”, o que implica uma adequação a uma ordem de discurso. Observemos, contudo, que os termos escrever ou escrita sequer fazem parte do dizer supramencionado, uma vez que, já naturalizados no discurso universitário-científico, publicar está para escrever, assim como publicação está para escrita, em uma relação de quase-sinonímia, na qual os termos podem ser facilmente intercambiáveis ou inscritos sob o mesmo selo da "produção acadêmica", já que tanto um quanto o outro perdem seu caráter singular de processo, de experiência, de saber. 
É esse deslizamento de significantes (e de sentidos) que nos permite afirmar que o mal-estar ou que o grande problema da escrita acadêmica não está no gesto de escrever ou nas dificuldades que os alunos ingressantes nesse meio possuem no trato com a língua. Também não acreditamos estar diante de um desconhecimento dos gêneros textuais acadêmico-científicos por parte dos entrevistados. Mais do que "o que escrever?", a inquietação que permanece está ligada à "para que ou para quem escrever": qual é o fim da escrit(ur)a? Para inserirmos essas questões na economia do discurso universitário-científico, atentemos para o dizer de Paulo.

R5)eu vejo por mim e vejo também pelos meus colegas essa/ essa preocupação em/ fazer um doutorado/ ter resultados bons/ poder publicar né// publicar tá contando um::/ tá contando bastante/ bastante e// é algo até meio perigoso porque você.../ só se fica olhando pra/ resultado que é bom/ né/ que/ a::/ deu um rendimento bom/ ou deu.../ aquele material que eu preparei tem características boas/ pode ser comercializável/ enfim (Paulo).

Em R5, além da relação de quase-sinonímia no deslocamento de escrever para publicar, atua o imperativo por (bons) resultados e por sua publicação, presentes também nos outros recortes já discutidos, o que nos permite revisitar a problemática da demanda pela "produção desmesurada de novos enunciados", como coloca Latour (1995), no excerto que citamos anteriormente. Mais do que fornecer resultados, a pesquisa científica deve gerar bons produtos, que, por sua vez, devem ser tornados públicos, mostrados, dados a ver, em um funcionamento espetacularizado. No entanto, podemos questionar quais critérios seriam empregados na caracterização de um resultado como bom e/ou se a escrita, por/em si mesma, poderia ser concebida como um bom resultado.

Ao encontro dessa indagação, uma possível resposta é formulada por Paulo em seu relato. Trata-se de considerar se a pesquisa "deu um rendimento bom" ou se "pode ser comercializável". Tal excerto nos permite observar a relação cada vez mais próxima entre universidade e mercado, produção de conhecimentos e produção de bens de consumo, imbricação, portanto, entre os discursos universitário-científico e capitalista. Desse modo, o conhecimento advindo do processo de pesquisa deve ser avaliado e legitimado por sua eficácia, sua rentabilidade, sua possibilidade de 
comercialização. Resumidamente, o suposto bom resultado é aquele passível de se tornar um produto consumível e, por que não, descartável. Seguindo a lógica desse funcionamento, talvez se deva a isso a insistência em não se perder muito tempo, em não se demorar no processo de escrita, o que sugere uma instrumentalização desta (e da língua) para a reafirmação do controle constante do/no âmbito universitário-científico, “cujo objetivo passa a ser a transformação rápida de conhecimentos e informações científicas e técnicas em novos valores mercadológicos"10 (Laperche, 2003, p.117).

No recorte a seguir, o dizer de Carolina, embora se direcione para fora desse ciclo, mostrando-se mais voltado para o campo do processo de formação e da experiência da escrita, permite-nos um último questionamento sobre os modos de subjetivação engendrados pelo discurso universitário-científico.

R6)eu acho que agora tem um pouco mais de cumplicidade/e/ eu me sinto/ mais/ ã::/ mais humana/ não tão máquina/ não tão.../ vamos produzir! o/ o meu mestrado era mais assim/ por produção/ seja uma máquina/ produza, produza/ tenha artigos e assim você vai ser feliz [riso] (Carolina).

Considerando que dizeres como esse são recorrentes e podem ser caracterizados como uma regularidade desse discurso, poderíamos apontar para indícios de uma reconfiguração nos modos de subjetivação contemporaneamente, ou seja, o sujeito estaria hoje sendo significado "como um sistema de processamento de informação - fruto do cognitivismo -, diríamos: um sujeito mais próximo da ideia [sic] de máquina”, como concebe Sanada (2004, p.186). É essa imagem do pesquisador como um sistema de processamento ou de conversão de resultados em escrita que Carolina mobiliza cínica ou ironicamente, como indica o riso ao final do recorte. Primeiro, porque sugere a incredulidade frente a esse imperativo e, segundo, porque a associação entre seja uma máquina e seja feliz é paradoxal. Carolina afirma que seu momento atual, o de pesquisa no doutorado, é regido por essa lógica, mas em menor intensidade (um pouco mais de cumplicidade [...] não tão máquina), o que a faz se sentir

\footnotetext{
10 Tradução nossa para: «dont le but devient la transformation rapide des connaissances et des informations scientifiques et techniques en nouvelles valeurs marchandes».
} 
mais "humana", mas também cúmplice. Se explorarmos os efeitos de sentido desse dizer, podemos observar que a cumplicidade se atrela a uma ação conjunta contrária a uma lei, a uma ordem (de discurso), o que nos permite pensar que a recusa ou a não participação na lógica dos resultados, na produção desenfreada de enunciados novos, potencializa uma cumplicidade enquanto resistência - nos termos de Coracini (2010) supramencionados - a essa maquinaria discursiva. E esse parece ser o fio que une os dizeres aqui discutidos.

\section{Considerações finais}

O discurso universitário-científico tem sido marcado não só pela tirania do conhecimento, que exige, a qualquer custo, a obediência ao mandamento desse saber, enquanto ordem que se apresenta como a verdade da ciência, mas também pela objetificação, pela mercantilização e pela anulação da dimensão subjetiva. Nesse sentido, Foucault já havia alertado que "libertemos a pesquisa científica das exigências do capitalismo monopolista' é talvez um excelente slogan, mas não será jamais nada além de um slogan" (Foucault, 2010, p.142). Entendemos, no entanto, que é aí que deve incidir uma escrita ${ }^{11}$ que perturbe e questione essa ordem, um falar de dentro que funcione como possibilidade de ruptura e de descontinuidade, de modo que o discurso universitáriocientífico também possa possibilitar a emergência de um saber que resiste, que questiona, que não trabalha de acordo com o imperativo do mestre moderno.

Se acreditamos nessa possibilidade e na de que, por meio da produção de conhecimento, o sujeito possa conhecer e produzir a si mesmo, é porque tomamos a escrita como uma escritura ou uma experiência, como sendo "qualquer coisa de que se sai transformado" (Foucault, 2013, p.289). Se os ruídos que analisamos se fazem ouvir, é porque não passaram pelo filtro que depura a voz e a escrita da ciência. Assim, para potencializarmos uma escritura no âmbito acadêmico, é preciso querer escutá-la, mas, sobretudo, praticar a escrit(ur)a como experiência, como possibilidade de mudar a si mesmo e não mais pensar da mesma forma.

${ }^{11}$ Em termos psicanalíticos, talvez, diríamos uma histericização do discurso, na medida em que o Discurso da Histérica interroga o significante mestre. 


\section{Referências}

BONINI, Adair; FIGUEIREDO, Débora C. Letramento e escrita acadêmica: uma experiência com o artigo de pesquisa. In: TFOUNI, Leda. V. Letramento, escrita a leitura: questões contemporâneas. Campinas: Mercado de Letras, 2010, p.121-142.

CORACINI, Maria José. Discurso e escrit(ur)a: entre a necessidade e a (im)possibilidade de ensinar. In: ECKERT-HOFF, Beatriz; CORACINI, Maria José. (Org.). Escrit(ur) a de si e alteridade no espaço papel-tela. Campinas: Mercado de Letras, 2010, p.1750 .

DA ROSA, Marluza. O discurso universitário-científico na contemporaneidade: marcas e implicações na constituição identitária do pesquisador em formação. 2013, 251 f. Tese (Doutorado em Linguística Aplicada), Instituto de Estudos da Linguagem, Universidade Estadual de Campinas, Campinas, 2013. Disponível em: <http://www.bibliotecadigital.unicamp.br/document/?view=000904523 >. Acesso em: 11 abr. 2015.

DERRIDA, Jacques. Mal de arquivo. Trad. Cláudia Rego. Rio de Janeiro: Relume Dumará, 2001a.

DERRIDA, Jacques. Posições. Trad. Tomaz Tadeu da Silva. Belo Horizonte: Autêntica Editora, 2001b.

DERRIDA, Jacques. Papel-máquina. Trad. Evando Nascimento. São Paulo: Estação Liberdade, 2004.

DERRIDA, Jacques; ROUDINESCO, Elisabeth. De que amanhã... Diálogos. Trad. André Telles. Rio de Janeiro: Jorge Zahar, 2004.

FIAD, Raquel. S. A escrita na universidade. Revista da ABRALIN, v. Eletrônico, n. Especial, p.357-369. 2 ${ }^{\mathrm{a}}$ parte 2011. Disponível em: <http://www.abralin.org/revista/RVE2/14v.pdf>. Acesso em 12 mar. 2015.

FOUCAULT, Michel. A ordem do discurso. Trad. Laura Fraga de Almeida Sampaio. 7. Ed. São Paulo: Edições Loyola, 2001.

FOUCAULT, Michel. A arqueologia do saber. Trad. Luiz Felipe Baeta Neves. Rio de Janeiro: Forense Universitária, 2009.

FOUCAULT, Michel. Microfísica do poder. Organização e tradução de Roberto Machado. Rio de Janeiro: Edições Graal, 2010.

FOUCAULT, Michel. Conversa com Michel Foucault. In: BARROS DA MOTTA (Org.). Ditos e escritos, v.VI. Trad. Ana Lúcia Pessoa. Rio de Janeiro: Forense Universitária. 2013, p.289-347.

KOYRÉ, Alexandre. Estudos de história do pensamento científico. Trad. Márcio Ramalho. 2ed. Rio de Janeiro: Forense Universitária, 1991.

KRISTEVA, Julia. Estrangeiros para nós mesmos. Trad. Maria Carlota Carvalho Gomes. Rio de Janeiro: Rocco, 1994. 
LACAN, Jacques. O seminário. Livro 17: o avesso da psicanálise. Trad. Ary Roitman. Rio de Janeiro: Jorge Zahar, 1992.

LACAN, Jacques. A ciência e a verdade. In: LACAN, Jacques. Escritos. Trad. Vera Ribeiro. Rio de Janeiro: Jorge Zahar, 1998, p.869-892.

LANDER, Edgardo. La ciencia neoliberal. Tabula Rasa. Colômbia, Bogotá, n.9, jul.-dez. 2008, p.247- 283.

LAPERCHE, Blandine. Les critères marchands d'évaluation du travail scientifique dans la nouvelleéconomie: lasciencecomme «forceproductive» et «outilmarketing». Innovations. 2003/1, n.17, p.105-138. DOI: 10.3917/inno.017.0105.

LATOUR, Bruno. (1991). Jamais fomos modernos. Trad. Carlos Irineu da Costa. Rio de Janeiro: Editora 34, 2009.

LOPES, Rosa Guedes. Quem é o sujeito da psicanálise? Tempo psicanalítico, Rio de Janeiro, v.40.2, 2008, p.249-272.

MENDELSOHN, S. Foucault avec Lacan: le sujet en acte. Filozofski vestnik, Letnik XXXI, Stevilka 2, p.139-169, 2010.

MILÁN-RAMOS, J. Guillermo. Passar pelo escrito: Lacan, a psicanálise, a ciência. Campinas: Mercado de Letras, 2007.

PASSONE, Eric. F. K. Fracasso na implementação de políticas educacionais: sintoma e emergência do sujeito. Estilos da clínica. São Paulo, v.18, n.1, jan./abr. 2013, p.53-70. Disponível em: <http://www.revistas.usp.br/estic/article/ view/59460/62627>. Acesso em: 29 maio 2014.

PEREIRA, Marcos Villela. A escrita acadêmica - do excessivo ao razoável. Revista Brasileira de Educação, v.18, n.52 jan.-mar., 2013, p.213-244. Disponível em:

<http://www.scielo.br/pdf/rbedu/v18n52/13.pdf>. Acesso em: 28 maio 2015.

QUINET, Antonio. A ciência psiquiátrica nos discursos da contemporaneidade. In: QUINET, Antonio et. al. (Org.). Psicanálise, capitalismo e cotidiano. Edições Germinal: Goiânia, Goiás, 2002, p.31-39.

RICOEUR, Paul. Soi-même comme un autre. Paris: Éditions du Seuil, 1990.

UYENO, Elzira. Escrita mal escrita ou mal-estar da escrita? A inelutável escrita de si. In: ECKERT-HOFF, Beatriz; CORACINI, Maria José (Org.). Escrit(ur)a de si e alteridade no espaço papel-tela. Campinas: Mercado de Letras, 2010, p.121-136. 


\section{Os mistérios que envolvem a escrita acadêmica}

Elizabeth Maria da Silva

O processo de transição do ensino médio para o ensino superior é marcado, na maioria das vezes, por sentimentos de medo, dúvida, ansiedade e incertezas. É tudo muito novo para os recém-ingressos. No ensino médio, eles estudaram e/ou escreveram, possivelmente, gêneros textuais diversos, que circulam em diferentes esferas sociais, a exemplo de cartas, depoimentos, resenhas jornalísticas, crônicas, artigo de opinião, editorial, entre outros. Todavia, quando chegam ao ensino superior, eles se deparam com gêneros específicos desse ensino: artigos acadêmicos, projetos de pesquisa, ensaios, monografia, etc. Tendo em vista que circulam e são produzidos na esfera acadêmica, é esperado que os estudantes não tenham familiaridade com eles e, consequentemente, não saibam como produzi-los. Surge, assim, uma tensão entre as práticas de escrita que os estudantes já possuem e as que são exigidas pela academia.

Nesse contexto, ao longo dos últimos anos, pesquisas sobre letramentos acadêmicos têm sido desenvolvidas tanto em âmbito internacional (Lea; Street, 1998, 2006; Lillis, 2003; Lillis; Scott, 2003; Zavala, 2009; Street, 2010) quanto, mais recente e paulatinamente, em âmbito nacional (Fischer, 2010, 2011; Marinho, 2010; Fiad 2011, 2013). Pesquisadores têm-se preocupado em apresentar os princípios teórico-metodológicos que fundamentam esse fenômeno, as questões ideológicas e epistemológicas que o subjazem, bem como as aplicações dos letramentos acadêmicos em contexto de ensino de escrita. 
Neste artigo, abordamos, brevemente, essas questões para problematizarmos o processo de solicitação de textos na esfera acadêmica. Para tal, organizamos as ideias em três seções. Na primeira, situamos o contexto histórico no qual o fenômeno dos letramentos acadêmicos surgiu nos Estados Unidos, no Reino Unido e no Brasil, bem como expomos as questões ideológicas e epistemológicas que fundamentam esse fenômeno. Na segunda, discutimos o contexto de ensino da escrita acadêmica, marcado por tensões entre as expectativas dos professores e as interpretações dos estudantes em relação ao que está envolvido nas produções textuais exigidas na universidade. Na terceira e última seção, elencamos algumas alternativas a partir das quais essas tensões podem ser, pelo menos, amenizadas.

\section{Letramentos acadêmicos: contexto histórico, questões ideológicas e epistemológicas}

Para melhor entendermos os pressupostos teórico-metodológicos que ancoram a abordagem dos letramentos acadêmicos, recuperamos o contexto que propiciou o seu surgimento: a expansão da educação superior. Tal expansão ocorreu em vários países, a exemplo dos Estados Unidos, Reino Unido e Brasil, mas em períodos diversos e com desdobramentos distintos.

Nos Estados Unidos, a expansão da educação superior ocorreu no final de 1960 e início de 1970. O crescimento da comunidade estudantil universitária desse país - heterogênea e diversificada - trouxe consigo uma necessidade de redirecionamento no ensino de escrita (Bazerman; Prior, 2007 [2004]). Nesse contexto, segundo Russel et al. (2009), surgiu um movimento pedagógico denominado Writing Across the Curriculum WAC, cujo objetivo era incorporar a escrita nas disciplinas ao longo dos currículos universitários, constituindo-se de duas tendências: Writing to Learn - WTL e Writing to Disciplines - WID.

Na segunda tendência do WAC, a WID, enfatiza-se o ensino da escrita em contextos disciplinares específicos, buscando-se desenvolver, tanto nos professores quanto nos alunos, o papel consciente da escrita. Isto, a partir da discussão sobre as necessidades de escrita dos alunos, a maneira pela qual ela funciona em cada uma das disciplinas e o modo como os estudantes podem se envolver ainda mais com ela dentro de cada matéria. Além disso, de acordo com Russel et. al. (2009), há uma preocupação em não trabalhar apenas com estruturas de gêneros, mas, principalmente, com as práticas nas quais eles estão inseridos, de modo 
que o discente possa compreender a funcionalidade que a escrita assume em determinada comunidade disciplinar.

No Reino Unido, a expansão universitária, ocorrida no final de 1980 e início de 1990, também se configurou como parte de uma ação governamental relativa à ampliação de acesso à educação superior, visando à inclusão tanto de estudantes locais quanto internacionais. 0 aumento no número de estudantes nesse nível de ensino, assim como aconteceu nos Estados Unidos, foi acompanhado pela presença de uma diversidade linguística, social e cultural que eles traziam consigo, além de dificuldades em relação à escrita acadêmica. Essas dificuldades eram justificadas pelo discurso oficial e por professores da educação superior a partir do argumento de que os alunos ingressavam na universidade com muitas lacunas no tocante à linguagem escrita, fato que estava gerando uma crise nesse nível de ensino. Logo, segundo Lea e Street $(1998,2006)$ e Lillis e Scott (2003), acreditava-se que, se cursos fossem ministrados com vistas a sanar as lacunas linguístico-textuais, essa crise seria resolvida.

Lea e Street (1998), discordando desse argumento de que a crise na educação superior, no Reino Unido, é devida às deficiências dos alunos, defendem que os problemas deles com a escrita parecem ser mais no nível epistemológico do que linguístico. Defendem ainda que esses problemas são causados, frequentemente, pelas lacunas entre as expectativas dos professores e as interpretações desses estudantes em relação ao que está envolvido nas escritas deles. É nesse contexto que propõem os letramentos acadêmicos como uma perspectiva a partir da qual as escritas dos estudantes poderiam ser entendidas.

Segundo esses autores, há três principais perspectivas ou modelos, que não se excluem e, por vezes, aparecem sobrepostos, a partir dos quais a escrita se configura na educação superior: study skills, academic socialization e academic literacies.

No primeiro modelo, o study skills, o letramento é concebido como um conjunto de habilidades individuais e cognitivas que os estudantes precisam adquirir e, assim, transferi-las para o contexto acadêmico. Desse modo, o desempenho demonstrado pelos alunos na escrita é resultado apenas dessas suas habilidades, sendo, portanto, eles mesmos os responsáveis pelo sucesso ou insucesso que apresentam nas atividades de escrita.

No segundo modelo, o academic socialisation, o letramento é considerado como um conjunto de variáveis que envolve os modos de falar, 
raciocinar, interpretar e usar as práticas de escrita valorizadas nas áreas e disciplinas da universidade. Nesse sentido, cabe ao professor introduzir os alunos na cultura universitária, com o intuito de que eles assimilem essas variáveis. Dessa forma, é papel do professor promover uma socialização acadêmica, contribuindo para a familiarização dos discentes com as práticas letradas acadêmicas.

No terceiro modelo, o academic literacies, o letramento é visto como uma prática social situada, que varia de acordo com as áreas e disciplinas em que é requerido. Focalizam-se, nesse modelo, a identidade, os significados sociais e os conflitos ideológicos subjacentes às práticas de letramento - estas entendidas, conforme Sreet (2012, p.77), como uma "concepção cultural mais ampla de modos particulares de pensar sobre a leitura e a escrita e de realizá-los em contextos culturais".

Essa noção de letramentos acadêmicos foi desenvolvida por pesquisadores ligados ao grupo dos Novos Estudos de Letramento (Street, 1984; Barton, 1984), no qual se defende que o foco de estudo não está tanto na aquisição de competências, como ocorre na abordagem autônoma, mas, sobretudo, nos significados dos letramentos como uma prática social que varia de acordo com o tempo e o espaço (Street, 2003). Sendo assim, consideram-se os letramentos um fenômeno historicamente situado, que assume significados específicos conforme os propósitos das instituições/grupos sociais em que aparece, bem como das relações de poder e de identidade que o subjazem.

De acordo com Lillis e Scott (2003), a perspectiva dos letramentos acadêmicos surge, portanto, como uma tentativa de promover reflexões sobre questões relativas à aprendizagem da escrita do estudante: (1) Qual a natureza da escrita acadêmica em diferentes contextos? (2) 0 que significa para os participantes fazer escrita acadêmica? (3) Como a identidade está ligada às práticas retóricas e comunicativas na academia?

Nesse sentido, uma das principais características desse modelo dos letramentos acadêmicos consiste na mudança de foco, quando se trata de entender a escrita do texto para as práticas. Não é que o texto será desconsiderado nesse modelo, mas entendido a partir das práticas sociais e culturais em torno das quais aparece. Segundo Lillis e Scott (2003), tal mudança de um único ou principal foco no texto ajudou no momento de considerar as várias dimensões da escrita acadêmica dos estudantes que estavam invisíveis ou permaneciam ignoradas: impacto das relações de poder na escrita 
do aluno; centralidade da identidade; construção do conhecimento ideologicamente inscrito, percepções dos estudantes sobre a escrita.

A investigação no campo dos letramentos acadêmicos tem, assim, uma natureza transformativa, pois há um interesse transformativo na construção de significados, um compromisso em buscar as experiências vividas pelas pessoas na tentativa de explorar o que está em jogo para elas, em contextos específicos (Lillis; Scott, 2003). Considerar os contextos específicos, nos quais a escrita aparece, é entender que o letramento acadêmico não é um fenômeno homogêneo, em que apenas as necessidades do estudante são enfatizadas, o que justifica, em geral, o uso do termo "letramento acadêmico", no singular. Pelo contrário, considerar as especificidades dos contextos significa entender os letramentos acadêmicos, no plural, a partir de questões mais amplas que permeiam a escrita acadêmica, a exemplo das práticas institucionais e das questões de poder (Lillis; Scott, 2003). Compartilhamos dessa segunda acepção, embora reconheçamos, junto às autoras citadas (Lillis; Scott, 2003), a fluidez do uso do termo "letramento acadêmico" que é usado tanto na forma singular quanto na plural, para se referir seja a contextos de pesquisa, seja de aplicação, seja a um mesmo contexto, por meio de um contínuo de ênfase. Tal fluidez se justifica pelas diferenças epistemológicas ligadas à posição ideológica dos pesquisadores que o utilizam.

Quanto à expansão do ensino superior do Brasil, diferentemente da dos Estados Unidos e do Reino Unido, é uma ação recente. Em 2007, foi implantado o Programa de Reestruturação das Universidades - Reuni, cuja proposta principal é o aumento do número de vagas de ingresso, especialmente no período noturno, acompanhada da redução das taxas de evasão e da ocupação de vagas ociosas. ${ }^{1}$ Por ser um fenômeno relativamente novo, não faz nem uma década do seu aparecimento, ainda são pouco conhecidos, no Brasil, os efeitos da expansão universitária para as práticas letradas dos estudantes, embora a reclamação dos professores quanto às dificuldades de escrita dos alunos seja bastante recorrente.

Ferreira (2013), com o objetivo de compreender os letramentos acadêmicos de expansão universitária, desenvolveu uma pesquisa em uma universidade pública federal brasileira criada nesse contexto. A autora buscou observar as especificidades das práticas de letramento na instituição selecionada; identificar as concepções de escrita presentes nos

\footnotetext{
${ }^{1}$ Disponível em: <http://reuni.mec.gov.br/>. Acesso em 23 de maio de 2014.
} 
discursos oficiais e as que orientam as práticas vivenciadas na universidade locus da pesquisa; e observar que significados as práticas de escrita adquirem para os diferentes sujeitos. Para tal, a pesquisadora analisou três dimensões: legislação específica que norteia o fazer acadêmico em nível nacional; documentos oficiais que orientam o fazer universitário na instituição pesquisada; e práticas acadêmicas desenvolvidas no curso de Bacharelado em Ciências e Tecnologia, especificamente nas disciplinas Leitura e Produção de Textos e Empreendedorismo. Os resultados obtidos na pesquisa, segundo Ferreira (2013), evidenciaram a heterogeneidade do contexto analisado, apontando para o fato de que as práticas de letramento são constituídas na e pela relação dos estudantes com a universidade.

Ao revisitarmos, rapidamente, o contexto de expansão da educação superior, nos Estados Unidos, Reino Unido e no Brasil, observamos que é apontada uma relação de causa e consequência entre expansão universitária e ingresso de estudantes com lacunas linguísticas e textuais. Todavia, pensando especificamente na realidade brasileira, entendemos ser necessário refletirmos um pouco mais sobre essa associação e ponderarmos algumas afirmações. Será que antes do Programa Reuni a universidade não recebia estudantes com lacunas de natureza diversa? Será que as dificuldades apresentadas pelos estudantes brasileiros dizem respeito apenas a aspectos linguísticos e textuais? Será que as práticas acadêmicas são explicitadas/ensinadas para aqueles que são novatos na instituição universitária? Continuamos pensando sobre esse assunto na próxima seção, na qual problematizamos um pouco o contexto de ensino da escrita acadêmica.

\section{Solicitação da escrita em contexto acadêmico: tensões entre professores e estudantes}

Alguns pesquisadores, que se têm dedicado ao estudo dos letramentos acadêmicos, buscam apresentar não apenas os princípios teórico-metodológicos que subjazem a esse fenômeno, mas também as suas possíveis aplicações em contexto de sala de aula. Uma das estratégias metodológicas utilizadas para tal é a adoção de uma abordagem etnográfica, que envolve a observação das práticas em torno da produção dos textos, bem como as perspectivas dos participantes sobre os textos e as práticas (Lillis; Scott, 2003). 
No âmbito desse segundo foco da abordagem etnográfica, perspectivas dos participantes sobre os textos e as práticas, Lea e Street (1998), Lillis (2003), Street (2010), Zavala (2009), Fischer (2010, 2011) e Fiad (2011, 2013), ao analisarem reflexões feitas por estudantes sobre as suas escritas acadêmicas, observam aspectos semelhantes nas falas desses sujeitos. Há dimensões "escondidas", subjacentes à avaliação da produção de textos acadêmicos, que não se referem apenas à estrutura do texto, mas também ao enquadramento (gênero, audiência, finalidade), à contribuição (para o conhecimento, para a área de pesquisa, para pesquisas futuras), à voz do autor, ao ponto de vista e às marcas linguísticas (Street, 2010). Os professores exigem tal produção sem explicitar, em geral, os critérios que considerarão no momento da correção, supondo, assim, que os alunos já saibam o que é esperado para escrever. Como os alunos não sabem, surge uma relação conflituosa entre as expectativas do professor e as interpretações do estudante, as quais não se restringem apenas à técnica de escrita e às habilidades de gramática, mas a aspectos relacionados com as relações de poder e de identidade que perpassam as interações entre os participantes.

Nesse contexto, é como se os estudantes participassem, na academia, de um "jogo de adivinhação", pois têm que descobrir quais são as expectativas do professor, ao solicitar determinada produção textual. Um dos estudantes britânicos que participaram como sujeito da pesquisa desenvolvida por Lea e Street (1998), quando indagado sobre as suas atividades de escrita acadêmica, afirmou que era consciente de que a escrita para um professor particular era específica, diferenciando-se da escrita para outro docente. Sentia, desse modo, a sensação de que cada professor parecia querer algo diferente, embora solicitasse o mesmo gênero. A pesquisa dos autores evidenciou, assim, que a escrita dos estudantes variava não apenas conforme o curso e a disciplina, mas também de acordo com o professor, de modo que, às vezes, no interior de um mesmo curso, professores individuais tinham opiniões diferentes sobre a escrita.

Esse "jogo de adivinhação" também tem sido foco de interesse da pesquisadora brasileira Raquel Fiad, a qual tem-se preocupado em observar as reflexões que estudantes universitários fazem em relação às suas escritas acadêmicas, mais especificamente, como elas são vistas em confronto com o que é esperado no contexto acadêmico.

Fiad $(2011,2013)$ desconstrói a tese de que os estudantes chegam à universidade sem saber escrever, questionando a visão de escrita que 


\section{Elizabeth Maria da Silva}

subjaz a essa crença - escrita como uma habilidade genérica, absoluta e aplicável a qualquer contexto. Segundo a autora (2003, p.471):

0 mito de que o aluno deve vir pronto para a universidade para ler e escrever deriva da visão de que letramento implicaria fundamentalmente o domínio de um conjunto de competências de leitura e escrita que os alunos têm de adquirir para depois transferi-las para outros contextos. Essa crença, no entanto, ofusca o fato de que os alunos universitários podem ter um bom domínio da língua, mas isso não os leva necessariamente a terem um bom domínio dos gêneros da esfera acadêmica, ou seja, como não existe uma fase de letramento ou um único letramento, são legítimas suas dificuldades para as práticas dos gêneros acadêmicos.

Nessa perspectiva, assim como as pesquisadoras brasileiras Marinho (2010) e Fischer (2010, 2011), Fiad (2011, 2013) reconhece que, ao entrarem na universidade, os estudantes são incumbidos de produzir diferentes gêneros, com os quais não estão familiarizados em suas práticas de escrita em outros contextos (inclusive escolares) e, na maioria das vezes, são mal avaliados por seus professores. Essa má avaliação é fruto da tensão que se instaura entre o que os professores esperam das escritas e o que os alunos de fato escrevem, como também foi constatado por Lea e Street (1998), Lillis (2003) e Zavala (2009).

Nesse contexto, Fiad $(2011,2013)$ defende a necessidade de analisar o que os estudantes têm a dizer sobre o que escrevem. Em seu trabalho publicado em 2011, evidencia o conflito apontado por estudantes do primeiro ano do curso de Letras, de uma universidade estadual brasileira, mostrando como eles escreviam e como eles deveriam escrever os textos acadêmicos - considerando o leitor do texto, o exercício da reescrita e a importância de uma linguagem organizada e clara.

Já no seu trabalho publicado em 2013, a autora apresenta uma proposta de abordagem da reescrita de textos acadêmicos, a partir da articulação entre uma perspectiva etnográfica de análise da escrita e uma concepção dialógica da linguagem. A partir da noção de text history, proposta por Lillis (2008), Fiad (2011, 2013) defende a importância de analisar as interações em torno da reescrita, considerando o texto e as conversas sobre ele. Segundo ela, "ouvir os outros - no caso, sujeitos que estão no processo de inserção no contexto acadêmico - faz parte do processo de enten- 
dimento desse letramento e também de práticas inovadoras no ensino de gêneros acadêmicos" (p.468). Nesse sentido, analisou os comentários de um texto produzido por estudantes universitário $\mathrm{s}$, com vistas a mostrar que, "no processo de escrita, também os diálogos travados entre os estudantes e seus interlocutores podem se constituir em mais uma prática a ser realizada no ensino da escrita acadêmica" (p.477).

Pasquotte-Vieira (2014) também adotou a noção de text history, mas fez isso para investigar a "história de texto" da dissertação de mestrado de uma mestranda do Curso de Pós-Graduação em Agricultura e Ambiente de uma universidade pública brasileira. Para tal, analisou: (a) a versão escrita da dissertação entregue para o exame de qualificação; (b) as notas escritas dos professores da banca sobre essa dissertação; (c) os comentários orais dos professores e da mestranda durante o exame de qualificação; e (d) os fragmentos extraídos de uma entrevista concedida pela mestranda após o exame. Ao triangular esses dados, a autora verificou que o processo de negociação entre os examinadores da dissertação e a pós-graduanda contribuiu para que esta (re)significasse as práticas acadêmicas de escrita, bem como se (re)posicionasse como um sujeito discursivo situado no lugar sócio-histórico da universidade. Assim, Pasquotte-Vieira (2014), sob a ótica de uma perspectiva etnográfica-linguística, defende que a negociação dialógica é fundamental à integração dos sujeitos às práticas letradas acadêmicas, as quais se desenvolvem nas interações discursivas entre os participantes da esfera acadêmica.

As reflexões feitas tanto pelos estudantes estrangeiros quanto pelos brasileiros, participantes das pesquisas referidas, apontam para a natureza complexa da escrita acadêmica. Também evidenciam a necessidade que eles têm de incorporar uma identidade discursiva, diferente da sua identidade biográfica (Ivanic, 1998),com vistas a atender às exigências do âmbito acadêmico e, assim, poderem ser reconhecidos como membros da academia por parte daqueles que têm o poder de fazê-lo: os agentes de letramento.

Assumir uma identidade discursiva que não é a deles, que não reflete a imagem que eles têm de si, é um desafio para os estudantes: "Eu quero dizer muitas coisas neste ensaio, mas eles não querem ouvir", desabafa um dos sujeitos da pesquisa desenvolvida por Lillis (2003, p.203). Paula está satisfeita por ter aprendido formas acadêmicas, mas não se sente ela mesma, quando escreve. Ela escreve o texto com o conteúdo que é esperado institucionalmente, mas desabafa que vive um conflito: "Quero 
falar, me comportar e ser a mesma que antes e pensar da maneira que eles pensam" [familiares] - constatações de Zavala (2009, p.355), quando analisou uma série de entrevistas feitas com a estudante universitária Paula sobre a sua escrita acadêmica.

Nessa perspectiva, ratificamos a produtividade de continuarmos investigando as percepções dos participantes quanto à escrita acadêmica, uma vez que são intensas e recorrentes as tensões que surgem em torno dessa escrita, haja vista a complexidade de sua natureza.

Na próxima e última seção deste artigo, apresentamos algumas sugestões para lidar com os conflitos em torno da escrita acadêmica.

\section{Alternativas para lidar com as tensões que envolvem a escrita acadêmica}

Em síntese, as pesquisas supracitadas evidenciam a necessidade de reconhecermos os letramentos acadêmicos como uma prática discur siva, social e situada e que está perpassada por ideologias, questões identitárias e relações de poder, as quais, na maioria das vezes, estão invisíveis/implícitas. Tais dimensões "escondidas" devem ser explicitadas para aqueles que querem se tornar membros da academia e, desse modo, ser reconhecidos como tais pelos agentes de letramento.

Nesse sentido, para que os conflitos entre as expectativas dos professores e as interpretações dos estudantes sejam pelo menos amenizados, cabe àqueles explicitarem para estes os critérios que norteiam a avaliação dos textos acadêmicos. Para isso, "precisam ficar claros os motivos pelos quais algumas práticas são privilegiadas no domínio acadêmico em detrimento de outras, qual significado determinada prática de letramento tem nesse domínio, o que significa justificar e argumentar de acordo com as convenções escriturais da academia" (Fiad, 2011, p.363).

Costa (2014, p.11) acrescenta que:

Talvez seja oportuno olhar criticamente a concepção de conhecimento que temos defendido, verificar em que medida o conhecimento é construído ou imposto dentro da universidade, explicitar para nós mesmos, primeiramente, as ideologias que subjazem às práticas de letramento acadêmico tal como elas se configuram hoje, pois de tão naturalizadas, elas parecem ter-se convertido em verdades absolutas. Em seguida, explicitá-las para os estudantes e, se necessário, colocá- las em xeque. 
Além disso, faz-se necessário, como sugere Lillis (2003), considerar o potencial dos talkbacks - um espaço para os estudantes refletirem sobre seu texto, dizerem o que gostam e o que não gostam da sua escrita. A utilização desse recurso pode contribuir para a aprendizagem dos estudantes, haja vista o processo de negociação que se estabelecerá entre professores e alunos no tocante aos elementos que estão envolvidos na produção textual.

Por fim, entendemos que o professor que ensina a escrita acadêmica poderia cultivar o equilíbrio entre despertara consciência críticados estudantes quanto às questões ideológicas e de poder que perpassam a produção dos gêneros e contribuir para que eles dominem o componente linguístico-textual desse gênero, a partir da apresentação de atividades de leitura e escrita, bem como do exercício da reescrita dos textos.

\section{Referências}

BARTON, D. Literacy: an introduction to the ecology of written language. Oxford: Backwell, 1984.

BAZERMAN, C; PRIOR, P. A participação em mundos socioletrados emergentes: gêneros, disciplinaridade, interdisciplinaridade. In: HOFFNAGEL, J. C; DIONÍSIO, A. P. (Organizadores).Escrita, gênero e interação social. Tradução e adaptação de HOFFNAGEL, J. C. São Paulo: Cortez, 2007 p.150-197.

COSTA, E. M. Considerações sobre o letramento acadêmico a partir do novo perfil dos graduandos em Letras/Espanhol. In: Colóquio Internacional Cultura Escrita e Letramento,5,2014, Belo Horizonte, p.1-11.

FERREIRA, M. de Lourdes Santos. Letramentos acadêmicos em contexto de expansão do ensino superior no Brasil. Tese (Doutorado em Educação), Belo Horizonte: UFMG, 2013.

FIAD, R. S. A escrita na universidade. Revista da ABRALIN, v. Eletrônico, n. Especial, p.357-369. 2a parte 2011. <http://www.abralin.org/revista/RVE2/14v.pdf>. Acesso em 14 de abr. de 2015.

FIAD, R. S. Reescrita, dialogismo e etnografia. Linguagem em (dis)curso, Tubarão, SC, v. 13, n. 3, p.463-480, set./dez. 2013.

FISCHER, A. Sentidos situados em eventos de letramento na esfera acadêmica. Revista do Centro de Educação, Santa Maria, v.35, n.1, p.215-228, maio/ago.2010. Disponível em: <http://cascavel.ufsm.br/revistas/ojs-2.2.2/index.php/reveducacao/article/view/2072/1248>. Acesso em 28 de maio de 2014.

FISCHER, A. Práticas de letramento acadêmico em um curso de engenharia têxtil: o caso dos relatórios e suas dimensões escondidas. Scripta, v. 15, n.28, p.37-58, $1{ }^{\circ}$ sem. 2011. Disponível em: <http://periodicos.pucminas.br/index.php/scripta/ article/view/4298/4443>. Acesso em 14 de abr. de 2015. 


\section{Elizabeth Maria da Silva}

IVANIC, R. Writing and identity: the discoursal construction of identity in academic writing. Philadelphia: Jonh Benjamins Publishing Company, 1998.

LEA, M. R; STREET, B. V. Student writing in higher education: an academic literacies approach. Studies in Higher Education. v.23, p.157, June 1998.

LEA, M. R; STREET, B. V. The Academic Literacies Model: theory and applications. Theoryinto practice. v.45, n.4, p.368-377, 2006.

LILLIS, T. Student writing as 'academic literacies': drawing on Bakhtin to move from critique to design. Language and Education, v.3, n.17, p.192-207, 2003.

LILLIS, T.; SCOTT, M. Defining academic literacies research: issues of epistemology, ideology and strategy. Journal of Applied Linguistics, v.4, p.5-32, 2003.

MARINHO, M. A escrita nas práticas de letramento acadêmico. Revista Brasileira de Linguística Aplicada, Belo Horizonte: Alab-Poslin, v.10, n.2, p.363-386, 2010.

PASQUOTTE-VIEIRA, E. Letramentos acadêmicos: um estudo de casos sobre o processo de negociação da escrita em um exame de qualificação. In: Colóquio Internacional Cultura Escrita e Letramento, 5, 2014, Belo Horizonte. Anais... Belo Horizonte, 2014. p.1-10.

RUSSELL, D. R.; LEA, M.; PARKER, J.; STREET, B.; DONAHUE, T. Exploring notions of genre in" academi cliteracies" and "Writing Across the Curriculum": approaches across countries and contexts. In: BAZERMAN, Charles; BONINI, Adair; FIGUEIREDO, Débora (Editores).Genre in a changing world. Fort Collins: The WAC Clearinghouse/West Lafayette: Parlor Press, 2009. p.395-423.

STREET, B. Literacy in theory and practice. Cambridge: Cambridge University, 1984.

STREET, B. What's "new" in new literacy studies? Critical approaches to literacy in theory and practice 2003. Current Issues in Comparative Education, v.5, n.2, 2003. Disponível em: < http://www.tc.columbia.edu>. Acesso em 10 de maio de 2014.

STREET, B. Dimensões "escondidas" na escrita de artigos acadêmicos. Tradução de Armando Silveiro e Adriana Fischer. Perspectiva: Revista do Centro de Ciências da Educação - UFSC, Florianópolis, v.8, n.2, jul./dez. 2010. Disponível em:<https://periodicos.ufsc.br/index.php/perspectiva/article/view/2175-795X.2010v28n2p541/18448>. Acesso em 10 de maio de 2014.

ZAVALA, Virgínia. “¿Quién está dicendo eso?” Literacidad académica, identidade[y poder en la educación superior. In. KALMAN; STREET (Coord.). Lectura, escritura e Matemáticas. México: Siglo XXI. p.348-363, 2009. 


\section{Autoria em redações do Enem e enunciação escrita: uma possível conjugação a partir da perspectiva de Benveniste}

Míriam Silveira Parreira

Quando fui para a escola pública, já tinha a noção vaga de um universo de palavras que era preciso conquistar. Durante o curso, minhas professoras costumavam passar exercícios de redação. Cada um de nós tinha que escrever uma carta, narrar um passeio, coisas assim. Criei gosto por esse dever, que me permitia aplicar para determinado fim o conhecimento que ia adquirindo do poder de expressão contido nos sinais reunidos em palavras [...] (Andrade, 1981, p.6-7).

0 fragmento do texto de Drummond retrata um indivíduo que, ao fazer os exercícios de redação, desenvolveu um gosto pelo dever de escrever o que era solicitado pelas professoras à medida que, dessa forma, era permitido a ele aplicar de forma adequada o conhecimento do poder de expressão das palavras quando bem articuladas. Parto da ideia apresentada, para anunciar a proposta deste trabalho: a escrita autoral da redação. Em meu entendimento, desde que tenha sentido, a apropriação do aparelho formal da língua é um poder de expressão que permite ao locutor constituir-se autor de seu texto, ou não, à medida que encaminha uma ação sobre o leitor, isto é, institui-se como "eu" para emergir como sujeito no discurso. 


\section{Míriam Silveira Parreira}

Para essa análise, situada no campo teórico da Linguística da Enunciação, conjecturo, pela via de Benveniste (1989, 1995, 2014), que se o candidato que escreve o texto segue todas as regras da avaliação a que é submetido, tem-se a impressão de que ele se constitui autor do texto que produz, mas não necessariamente, pois essa condição da enunciação escrita implica um modo como o saber manejar a língua incide nesse aluno a ponto de ele se subjetivar, ou não, e constituir-se autor.

Meu interesse por discutir a autoria em redações deve-se ao fato de que, ao participar de bancas corretoras de redação, presenciei inúmeras discussões a respeito de como avaliar esse quesito. Ao questionar corretores de redação e também coordenadores de bancas corretoras de avaliação de redação obtive respostas diferentes e ouvi também que talvez não haja autoria em redações de processos seletivos. Entretanto, ao ler o Guia do Participante do Exame Nacional do Ensino Médio (ENEM), ao longo do documento, o aluno que faz a prova é tratad como "participante", mas duas afirmações contidas nele são passíveis de análise e reflexão:

Apresenta informações, fatos e opiniões relacionados ao tema proposto, de forma consistente e organizada, configurando autoria, em defesa de um ponto de vista. [...] 0 quinto aspecto a ser avaliado no seu texto é a apresentação de uma proposta de intervenção para o problema abordado. Por isso, a sua redação, além de apresentar uma tese sobre o tema, apoiada em argumentos consistentes, deve oferecer uma proposta de intervenção na vida social. Essa proposta deve considerar os pontos abordados na argumentação, deve manter vínculo direto com a tese desenvolvida no texto e coerência com os argumentos utilizados, já que expressa a sua visão, como autor, das possíveis soluções para a questão discutida (Guia do participante, 2013, p.19-22).

Outra avaliação chamou minha atenção: a nota máxima ao participante que tem repertório. Refere-se à avaliação da segunda competência, que atribui nota máxima (200 pontos) ao participante pelo que se encontra transcrito no Guia do Participante: "Desenvolve o tema por meio de argumentação consistente, a partir de um repertório sociocultural produtivo, e apresenta excelente domínio do texto dissertativo-argumentativo" (Guia do participante, 2013, p.17).

E nota máxima também ao participante que desenvolve bem a 
quarta competência, conforme o que se encontra escrito no Guia do Participante (2013, p.21): "Articula bem as partes do texto e apresenta repertório diversificado de recursos coesivos". Essa avaliação relacionada ao repertório também será abordada nesta pesquisa porque pode ter relação com ser autor, ou não, daquilo que é produzido na avaliação de redação.

Outra consideração importante a ser feita é que ENEM solicita a produção de um texto em prosa, do tipo dissertativo-argumentativo. Na redação, o aluno deve defender uma opinião, uma tese a respeito do assunto proposto, apoiando-se em argumentos consistentes organizados de forma coerente e coesa. 0 texto, então, deve caracterizar-se pela objetividade. Nesse sentido, assumo que essa condição figurativa da enunciação escrita pode funcionar como elemento das questões da intersubjetividade de Benveniste. Por esse motivo, trabalharei, nas análises das redações, com as definições de subjetividade e de autoria.

Ressalto que a subjetividade de que se trata não se opõe à objetividade solicitada pelo gênero textual, uma vez que a objetividade do gênero é só um apagamento, uma espécie de não explicitação do "eu". Isto é, acredito que a subjetividade propiciadora de autoria pode estar presente, ou não, no texto elaborado. Para fundamentar essa afirmação e refletir sobre a condição figurativa da enunciação escrita em redações produzidas no Exame Nacional do Ensino Médio, vou me valer do lugar teórico da Linguística da Enunciação, levando em conta a definição de Benveniste (1989, p.82) de que enunciação é "colocar em funcionamento a língua por um ato individual de utilização da língua".

Considero, portanto, junto com Benveniste (1995), a enunciação como ato individual de uso da língua e que a subjetividade consiste na capacidade do sujeito de assumir a posição de autor e tornar a escrita única e significativa. A subjetividade, segundo o linguista, ocorre notadamente na relação entre eu e $t u$, consiste na maneira de organizar a língua a ponto de torná-la um discurso que tenha uma relação de consonância com a realidade social.

Benveniste (1995) defende, ao contrapor linguagem e instrumento, que a palavra só assegura a comunicação se estiver habilitada a isso por meio da linguagem, pois a palavra é uma atualização da linguagem. Vista dessa forma, aproxima-se da noção de enunciação enquanto serve como instrumento de atualização da língua em discurso, pelo locutor, que a toma para si e constitui-se sujeito. A capacidade de mobilizar a língua e produzir 
um enunciado, qualificando-se como "eu" para emergir como sujeito no discurso define a subjetividade. Esse ato individual pressupõe uma ação sobre a língua, que pode ser denominada uma apropriação no momento da enunciação. Ao enunciar, aquele que produz um texto, qualifica-se como "eu" e institui o outro, um "tu" com quem fala. A enunciação, sendo irrepetível porque é nova cada vez que o aparelho formal eu-tu-ele-aquiagora é instaurado, é uma alocução que possibilita a conversão individual da língua em discurso.

Ao tratar da enunciação escrita, Benveniste (1989, p.90) afirma que nela "o que escreve se enuncia ao escrever e, no interior de sua escrita, ele faz os indivíduos se enunciarem". o quadro formal que está esboçado no artigo "O aparelho formal da enunciação" apresenta a subjetividade e a intersubjetividade como constitutivas da língua e menciona, em específico, a escrita, abrindo perspectivas para a análise das formas complexas do discurso. A partir da perspectiva benvenistiana, examinarei a constituição, ou não, de certo efeito de autoria em redações produzidas por candidatos que fizeram a prova do Exame Nacional do Ensino Médio (ENEM), a partir da condição figurativa da enunciação escrita desses textos.

Mobilizando, então, as definições de Benveniste $(1989,1995,2014)$, proponho que enunciação e autoria possam conviver e ser conjugadas em uma teoria do discurso. Arrisco definir como autor aquele que aproveita a oportunidade para, em condição figurativa da enunciação escrita, expressar sua opinião, atuando como sujeito do discurso.

A tentativa de conjugar autoria e enunciação origina-se da visão comungada com leitores benvenistianos que vêm apresentando a escrita da redação como uma experiência de linguagem, o lugar de sujeito que se constitui na e pela língua.

\section{Fundamentação teórica}

De acordo com Agustini e Borges (2013), enxergo na teoria de Benveniste $(1989 ; 1995 ;$ 2014): "sustentação para compreender que tal experiência de linguagem se constitui da possibilidade de situar-se subjetivamente na e pela linguagem" (Agustini; Borges, 2013, p.3).

No artigo "O aparelho formal da enunciação", Benveniste apresenta a subjetividade e a intersubjetividade como constitutivas da lín- 
gua. Isso significa que o estudioso já visualizava a enunciação escrita e que ela também implica uma relação de intersubjetividade entre os indivíduos ao se enunciarem. 0 ato individual, para o linguista que define enunciação como ato individual de colocar a língua em funcionamento, pressupõe uma apropriação da língua no momento da enunciação. Isso pode ser observado na fala e estender-se para a escrita quando o locutor maneja a língua com a finalidade de produzir um enunciado. Logo, pode-se pensar a escrita também como um lugar de enunciação com características específicas.

Nesse sentido, a linguagem possibilita ao indivíduo constituir-se como falante e como sujeito. Essa noção postulada por Émile Benveniste direciona os estudos sobre a linguagem tanto para a enunciação quanto para a intersubjetividade. Ele trata a intersubjetividade como constitutiva da linguagem ao afirmar que o que encontramos no mundo é um homem falando com outro homem. 0 que propõe, então, é uma concepção de linguagem que veja o indivíduo como sujeito porque "é um homem falando que encontramos no mundo, um homem falando com outro homem, e a linguagem ensina a própria definição do homem" (Benveniste, 1989, p.285).

Ao afirmar a relação locutor/alocutário, em que eu se torna "eu" quando se dirige a alguém, Benveniste preconiza essa polaridade como fator fundamental para a intersubjetividade, isto é, a relação de alocução entre "eu" e "tu" é que torna possível a comunicação linguística.

0 fato de o locutor dizer "eu" estabelece uma relação de intersubjetividade, pois o "eu" sempre "fala de" ou "a alguém", em uma relação que se atualiza e se alterna. A subjetividade de formas como "eu" e "tu" é que torna possível ao locutor propor-se como sujeito porque são somente possibilidades da língua até o momento em que o locutor toma a palavra e produz um enunciado. Para Benveniste (1989, p.86) ao "colocar em funcionamento a língua por um ato individual de utilização” o locutor emprega muito mais do que as formas possíveis, que só significam na e pela enunciação, porque as converte em discurso. Benveniste (1989) assim define situação de discurso:

circunstância irrepetível de apropriação da língua que instaura a interlocução e a instância espacial e temporal coextensiva e contemporânea da enunciação. A língua coloca em relevo uma dissimetria que está na natureza desigual da experiência (Benveniste, 1989, p.88). 
Desse modo, institui o quadro formal da enunciação - definida em relação à língua utilizada individualmente - como um processo de apropriação. Processo em que, ao atuar na e pela linguagem, o locutor produza algo que signifique, enunciando-se, de um lado, por meio dos índices específicos tratados por Benveniste: de pessoa (eu-tu), de ostensão (este, aqui...), manifestados em um tempo sempre "presente", designando um "eu-tu-ele-aqui-agora", tendo em vista que a enunciação está sempre se modificando. E, de outro, por meio de um aparelho de funções, como interrogação, intimação e asserção, que implicam o locutor posicionar-se no discurso e constituir o outro, correferindo ao enunciar-se.

No sentido de funções, as formas linguísticas preexistentes possibilitam a "semantização", isto é, tornar singular o que é comum a todos. É pelo aparelho formal da enunciação que o locutor busca constituir-se como sujeito e instaurar o outro diante do ato individual de utilização da língua. A apropriação depende da relação entre a intersubjetividade, constituída na enunciação e a subjetividade das formas possíveis na língua. Em outras palavras, é a relação intersubjetiva que possibilita a subjetividade.

E a constituição da subjetividade pela escrita ocorre na relação que os locutores estabelecem. Por esse motivo, almejo, na teoria enunciativa de Benveniste, o fundamento teórico que permitirá, considerando as redações como condição figurativa de enunciação escrita, analisar se há nelas uma constituição, ou não, de certo efeito de autoria, que é essa condição figurativa.

A análise que pretendo fazer, da perspectiva teórica benvenistiana, tem como propósito demonstrar - tendo em vista que o modelo de análise depende do ponto de vista do pesquisador - o ato de enunciação como individual e possibilitador da singularização do locutor que, ao manejar a língua e produzir discurso, torna-se sujeito de linguagem e, a meu ver, pode se constituir autor de sua redação.

Penso que essa conjugação pode contribuir para que a escola passe a tratar a escrita, de acordo com Endruweit (2006), como um acontecimento enunciativo. Além disso, a devida importância dada aos aspectos discursivos da redação pode contribuir também para uma forma de avaliar autoria em redações escolares e no ENEM. Portanto, partirei da teoria da enunciação de Benveniste, basicamente do texto "O aparelho formal da enunciação" (1989), em que a noção de enunciação é apresentada como ato individual de utilização da língua e também do que ele postula sobre escrita nas "Últimas aulas" no Collège de France (2014). 
Benveniste (1989), ao enfatizar a necessidade de estudo de muitos outros desdobramentos em relação à enunciação, aponta para a necessidade de distinguir enunciação falada de enunciação escrita e amplia as perspectivas de análise. São palavras dele:

Seria preciso também distinguir a enunciação falada da enunciação escrita. Esta se situa em dois planos: o que escreve se enuncia ao escrever e, no interior de sua escrita, ele faz os indivíduos se enunciarem. Amplas perspectivas se abrem para a análise das formas complexas do discurso, a partir do quadro formal esboçado aqui (Benveniste, 1989, p.90).

É com base no que foi esboçado por Émile Benveniste que proponho analisar a maneira de o locutor apropriar-se da língua na escrita da redação do ENEM para enunciar sua posição de sujeito de seu discurso. Ressalto a afirmação do estudioso, de que a Linguística é a ciência que tenta compreender a linguagem para possibilitar seu estudo como sendo o de objetos concretos. Uma ciência que pretende reunir tudo que se relaciona à linguagem e se ocupar do fenômeno que a constitui sem negligenciar a linguagem que se transforma em escrita.

$\mathrm{Na}$ tentativa de analisar a enunciação escrita, comungo com o ponto de vista de Knack (2012) no que se refere às formas complexas do discurso citadas por Benveniste (1989, p.90), por isso entendo também que tais formas linguísticas podem ser tanto orais quanto escritas. Dessa forma, para proceder à análise da redação que constitui o corpus deste trabalho, adotarei os conceitos de subjetividade, de "sujeito" e de enunciação de Benveniste. Enunciação para o linguista é o próprio ato de utilização individual da língua, que antes da conversão é apenas possibilidade da língua.

Em seu artigo "O aparelho formal da enunciação", já citado antes, na passagem em que Benveniste (1989, p.90) apresenta a subjetividade e a intersubjetividade como constitutivas da língua, ele faz uma menção específica à escrita. Situa a escrita em dois planos: o que escreve se enuncia e no interior de sua escrita faz os indivíduos se enunciarem. Afirma que esse quadro formal que esboça abre perspectivas para a análise das "formas complexas do discurso".

Nunes e Flores (2012) entendem a expressão "formas complexas do discurso" mencionada por Benveniste (1989) como objeto de estudo da metassemântica. Para os autores, Benveniste anunciou o estudo no 


\section{Míriam Silveira Parreira}

texto "Semiologia da língua" (1995) ao propor dois tipos de análise para ultrapassar a noção de signo que o "Curso de Linguística Geral” (2006), publicado por discípulos de Saussure, apresentou como princípio único de que dependeriam a estrutura e o funcionamento da língua. São elas:

- na análise intralinguística, pela abertura de uma nova dimensão da significância, a do discurso, que denominamos semântica, de hoje em diante distinta da que está ligada ao signo, e que será semiótica;- na análise translinguística dos textos, das obras, pela elaboração de uma metassêmica que se construirá sobre a semântica da enunciação (Benveniste, 1989, p.67).

Tomarei como base para análise, as considerações da passagem transcrita por entender que as redações do ENEM também são textos que se encontram entre as formas complexas do discurso. Segundo Nunes e Flores (2012), os dois tipos de enunciação se diferenciam em alguns aspectos. Na enunciação oral há um locutor e um alocutário, enquanto que na escrita há um autor e um leitor. 0 tempo em uma e outra enunciação também as diferencia. Na oralidade a troca é direta, já na escrita ela supõe o tempo da leitura.

Para Nunes e Flores (2012), a enunciação escrita instaura duas enunciações, a do autor do texto e a das outras enunciações presentes no texto. De acordo com Cervo (2013), que analisou redações de vestibular, analisarei a enunciação do participante do ENEM tendo em vista a redação como ato e como produto do ato.

Enquanto ato, analisarei as relações entre "eu" e "tu" estabelecidas pelo locutor. Segundo Benveniste (1989), o ato de produzir enunciados ou processo de apropriação da língua por meio de índices específicos e procedimentos acessórios é o que permite a enunciação, que converte a língua em discurso. Esse movimento só é possível com a intervenção do locutor. Esse ato individual de utilização da língua para enunciar instaura o "tu" para falar do "ele". Ao instaurar o "eu" e o "tu" relacionados entre si, Benveniste (1995) formula a noção de (inter)subjetividade. Enquanto produto do ato, meu olhar estará voltado para o modo de conversão da língua em discurso para a instauração do sentido.

A partir dessas considerações, pode-se dizer que a (inter)subjetividade depende da situação de alocução entre "eu" e "tu”. Knack (2012) explica que o que difere as categorias de pessoa ("eu-tu") e não pessoa 
("ele") encontra-se na referência entre as categorias. A de pessoa situa-se no nível pragmático da linguagem e remete à própria instância de discurso, enquanto a de não-pessoa pode ser encontrada no nível sintático. Nela o referente pode ser objetivo porque não depende da instância de discurso. Para Benveniste (1995), o que define a subjetividade é a capacidade do locutor propor-se como "sujeito". As aspas são colocadas pelo linguista para tratar o sujeito como uma categoria linguístico-discursiva. Segundo Benveniste (1995, p.286) "É na linguagem que o homem se constitui como sujeito". Isso indica que a subjetividade se estabelece na e pela linguagem.

A Teoria da Enunciação de Benveniste, portanto, ao relacionar semantização e sintagmatização e, com isso, estabelecer relação entre forma e sentido, pode auxiliar na fundamentação de um estudo da língua que permita ao aluno um estudo mais significativo e contribua para a produção de um bom texto. Sendo assim, a compreensão dessa relação pode tornar a escrita da redação mais significativa, pois vista dessa maneira, o ensino e a produção de textos estarão voltados para o quê (semantização) e para o como dos textos (sintagmatização), como asseverou Mello (2012).

Portanto, para o desenvolvimento de meu trabalho, vou me valer principalmente da definição de Benveniste (1995) acerca de subjetividade, tendo como objetivo geral a discussão, tendo em vista a redação do ENEM como condição figurativa de enunciação escrita, do modo como o "eu" consegue estabelecer uma relação de interlocução com o "tu", ao colocar a língua em funcionamento em um ato individual, e remeter a algo singular para constituir-se autor de seu texto. Para a análise, considerarei, então, os movimentos enunciativos escritos pelo participante do ENEM.

Nesse caminho, meus objetivos específicos, na perspectiva da redação vista como ato de enunciação, são: a) refletir sobre a necessidade de olhar para a proposta e a produção da redação do ENEM como instauradoras do ato de enunciação em contexto de avaliação; b) reconhecer e analisar os movimentos enunciativos, de singularidade presentes nas redações e discutir em que medida estão relacionadas à noção de autoria; c) discutir como se dá a relação do locutor com a proposta de redação e o modo de interação dele com o interlocutor ao manejar a língua para constituir-se sujeito e produzir sentido, tornando-se autor do texto que produz; d) verificar em que medida os movimentos singulares 


\section{Míriam Silveira Parreira}

de manejo da língua em redações do ENEM não considerados pela banca avaliadora como autoria apontam para um trabalho de elaboração de texto como constituição de autor e refletir sobre a existência de autoria, ou não, nessas redações; e) analisar de que modo o repertório do participante do ENEM pode incidir na elaboração de seu texto a ponto de possibilitar que ele se subjetive, ou não, em um certo efeito de autoria.

\section{Metodologia de pesquisa}

Na análise que pretendo fazer, tecerei considerações acerca dos elementos que constituem o quadro formal da enunciação: a) o ato de leitura da instrução e compreensão da proposta, juntamente com a instauração do participante do ENEM como locutor que se instancia como "eu” e dirige-se a um "tu", que é o avaliador da redação; b) os movimentos enunciativos escritos pelo participante do ENEM/locutor da redação; c) o modo como o saber incide no candidato a ponto de ele se subjetivar, ou não, em um certo efeito de autoria.

Na análise, procurarei identificar as marcas de intersubjetividade deixadas pelo sujeito no processo de apropriação da língua, tomando por base a teoria de Benveniste. Entendo que isso só é possível porque a proposta de redação apresentada supõe a relação "eu-tu/ele", vista como posicionamento intersubjetivo. Nesse sentido, verificarei como o candidato, na prova de redação do ENEM, institui-se locutor na instância enunciativa para se instaurar como sujeito e instaurar o outro naquilo que diz.

Como meu propósito não é quantitativo e sim qualitativo, selecionei para análise um texto que foi considerado pela banca do ENEM como configurador de autoria. Para não apresentar um trabalho apenas de constatação, vou me debruçar, em outro momento de minha pesquisa de doutorado, na análise de outras redações que, segundo a banca do ENEM, não têm autoria, para pensar em autoria e subjetividade tendo em vista a visão enunciativa benvenistiana.

\section{Uma proposta de análise}

A seguir, por se tratar apenas de um esboço de análise, apresentarei uma leitura possível de um texto que foi avaliado com nota máxima em todos os critérios do ENEM. 
A proposta da prova de redação do ENEM/2013 exigiu a produção de um texto em prosa, do tipo dissertativo-argumentativo, sobre os efeitos da Lei Seca. E exigiu, ainda, que o participante defendesse uma tese, uma opinião acerca do tema proposto. As cinco competências analisadas foram:

Competência 1: Demonstrar domínio da norma padrão da língua escrita.

Competência 2: Compreender a proposta de redação e aplicar conceitos das várias áreas de conhecimento, para desenvolver o tema dentro dos limites estruturais do texto dissertativo-argumentativo. Competência 3: Selecionar, relacionar, organizar e interpretar informações, fatos, opiniões e argumentos em defesa de um ponto de vista. Competência 4: Demonstrar conhecimento dos mecanismos linguísticos necessários para a construção da argumentação. Competência 5: Elaborar proposta de intervenção para o problema abordado, respeitando os direitos humanos(Guia do participante, 2013, p.8).

Registro, então, um esboço de análise na perspectiva enunciativa, conforme Émile Benveniste (1989, 1995, 2014), mais particularmente segundo conceitos explorados na fundamentação teórica deste trabalho. Meu objetivo é verificar se na redação analisada o sujeito-autor emerge/ aparece, possibilitado pela intersubjetividade, no modo singular de mobilizar as escolhas linguísticas e consegue instaurar no outro aquilo que é dele, na tentativa de atender às exigências do ENEM e encaminhar uma ação sobre o leitor, produzindo sentido. A meu ver, esse movimento pode ser um modo de se constituir autor.

O propósito deste trabalho é que a escrita da redação seja pensada como enunciação escrita. É nisso que vou me basear para a análise: existe um sentido estabelecido pela língua e um sentido construído na enunciação, que é adaptável porque implica um sujeito. Sob esse prisma, a estrutura formal da língua se estende ao uso que o locutor faz dela, semantizando-a e atualizando o sentido no discurso.

Assim, a redação do ENEM, objeto de estudo nesta tese, será tomada como enunciação escrita em que o "eu" mobiliza a língua no intuito de instaurar o "tu" e marcar seu lugar, mesmo que se refira ao que já foi dito anteriormente, pois o modo de utilizar a língua nunca se repete.

Dessa forma, o professor, ao considerar o texto que o aluno produz na escola como produto de enunciação, não pode ignorar sua posição de 


\section{Míriam Silveira Parreira}

interlocutor diante do aluno que aprende a redigir. Considero estar em situação semelhante o corretor que avalia redações do ENEM. Logo, na prática da correção, a subjetividade emerge. E a partir dela, a diferente formação de cada avaliador pode interferir na análise do texto como autoral ou não.

Isso implica que o trabalho de escrita da redação subentende uma interlocução e a tentativa de redigir um bom texto aos olhos de quem vai avaliar. Logo, a relação entre o autor da redação e o leitor-avaliador e a posição de cada um estarão implicadas nas formas da língua. Essa forma de expressão singular é permitida no e pelo uso da língua.

A proposta de redação do ENEM/2013 solicita ao participante, na enunciação escrita, a elaboração de um texto de gênero dissertativo argumentativo, a partir de uma problemática que é apresentada em relação aos efeitos da implantação da Lei Seca e de textos motivadores. $\mathrm{Na}$ redação, aquele que escreve deve expor seu ponto de vista sobre o assunto em questão, que foi escolhido pela instituição que elaborou a proposta, isto é, o tema é compulsório, não há escolha, a proposta é coercitiva. 0 participante do ENEM deve, então, escrever para um leitor que tem conhecimento da proposta. Na redação, deve assumir uma posição e argumentar na tentativa de sustentar o que está dizendo.

No ENEM, a proposta exige do participante o uso dos conhecimentos construídos ao longo de sua formação para a defesa de um ponto de vista. Assim se estabelece o processo de escrita e avaliação da redação do ENEM, sob um olhar da perspectiva da enunciação, o participante lê a proposta e executa o que foi solicitado. Na proposta, o locutor que representa a instituição convoca o "tu", por meio do modo imperativo, a se enunciar. Essa relação instaura um diálogo entre o "eu" e o "tu". Como não há enunciação sem diálogo, a proposta da instituição configura-se como um ato de enunciação que convoca o participante a dissertar sobre os efeitos da implantação da Lei Seca no Brasil e, ao final do seu texto, propor uma intervenção para o problema.

Além da instrução direta para a redação do texto, a proposta apresenta textos motivadores, articulados entre si para tratar dos problemas que dirigir alcoolizado podem acarretar e apontam algumas ações para evitar que as pessoas dirijam alcoolizadas. São textos que podem ajudar o participante do ENEM a argumentar, mas sem copiá-los. Funcionam como subsídios para o candidato desenvolver a redação. Assim, a proposta de redação pode ser vista, do ponto de vista da enunciação, como um "eu" que convoca um "tu" a dissertar sobre os efeitos da Lei Seca. 
A redação transcrita a seguir foi avaliada com nota 1000 , isto é, obteve nota máxima em todos os critérios. 0 que significa que foi avaliada como configurando autoria. Como o ENEM não avalia título e há poucas linhas para o desenvolvimento do tema bem como tempo exíguo para fazer 180 questões e ainda a redação, a sugestão de muitos professores é que o aluno/participante do ENEM não perca tempo com a elaboração de um título para seu texto. Por esses motivos, a redação analisada não possui título.

A implantação da Lei Seca no Brasil é algo que reflete a imprudência dos motoristas ao dirigirem embriagados. Extremamente positiva para o país, ela já mostrou que é imprescindível para que muitas pessoas passem a valorizar mais a própria vida e a das outras. Acontece que essa lei, infelizmente, ainda não mobilizou todos como deveria.

É indiscutível, então, que a Lei Seca não poderia deixar de ser aplicada no Brasil. Isso porque os motoristas do país dificilmente adquirem consciência sem que punições sejam implantadas. Assim, com um menor número de pessoas dirigindo embriagadas e, dessa forma, comprovadamente com os reflexos comprometidos, reduziu-se a necessidade de atendimentos hospitalares, já que se nota uma diminuição na incidência de acidentes decorrentes do consumo de álcool.

Essa diminuição dos acidentes provocados por pessoas embriagadas resulta, por sua vez, em menos mortes no trânsito. Dessa maneira, com tantos pontos favoráveis à sociedade brasileira, é perceptível que muita gente já aderiu à campanha do "motorista da rodada", em que um amigo deixa de beber para dirigir para sua turma. Também foi noticiada, recentemente, a existência de bares que se adaptaram à nova realidade e possuem motoristas prontos para levar o cliente em casa. Sem contar, ainda, os estabelecimentos que fazem parcerias com táxis. Isso tudo ajuda a comprovar que, mesmo com o atual enrijecimento da Lei Seca, agora intolerante a qualquer quantidade de álcool no organismo, não é difícil respeitá-la, evitar multas e cadeia e, ainda, preservar vidas.

O lado triste dessa história é que continuam existindo aqueles que não foram tocados pela lei. Uma simulação feita em um noticiário em televisão aberta mostra que poucas pessoas se mobilizam para ajudar a mulher que não quer deixar o marido dirigir bêbado. E não se descarta, além da falta de consciência de alguns como os da reportagem, a falta de bafômetros e de fiscalização em várias cidades.

Portanto, para que a Lei Seca, tão benéfica, possa atingir a todos, seriam necessárias mais campanhas midiáticas, além de mais etilômetros e fiscalização que englobasse todos os municípios do Brasil. É claro que isso representa um grande investimento, mas nunca é demais que se garanta o direito humano mais nobre: a vida. 
Ao aprender características do tipo dissertativo-argumentativo na escola, o aluno é orientado a ser objetivo, impessoal, isto é, a usar a terceira pessoa. Como estou propondo uma análise em termos enunciativos, é possível dizer que o uso da terceira pessoa, na redação transcrita, marca o apagamento do "eu", um disfarce da subjetividade configuradora de autoria, mas ele está presente no texto. A tentativa é ser impessoal. Isso significa que "entrar no jogo" acarreta uma tensão enunciativa. 0 sujeito que emerge no texto deve ser objetivo e ao mesmo tempo deve defender um ponto de vista, isto é, subjetivar-se. Afinal, esse autor que não é o do sentido literário, mas aquele que se marca na linguagem, é um sujeito, na posição de autor, que maneja a língua ao seu modo ao redigir o texto que foi solicitado no ENEM.

Na perspectiva enunciativa, o quadro de enunciação instaura-se, mesmo não havendo a marca "eu" que remete à subjetividade, desde a proposta da instituição que tem um locutor que é apagado. Com esse olhar, do ponto de vista da enunciação benvenistiana, pode-se dizer que a partir da proposta, a redação apresentada foi escrita por um locutor e participante do ENEM instituído em uma relação de (inter)subjetividade entre o "eu" institucional e o "tu" avaliador do texto. Cabe ressaltar que a redação apresenta correção gramatical, clareza nas frases construídas, organização e progressão na argumentação, além de ser coerente, atender à proposta e às características do gênero. Possui também estrutura composicional que facilita o entendimento da abordagem.

Como a avaliação de um texto considerado bom deve ultrapassar os aspectos gramaticais e textuais e atingir os aspectos discursivos, podese dizer também que a estrutura composicional atende à organização do gênero elaborado. Além disso, cabe ressaltar que a argumentação foi aprofundada quando o "eu", mesmo não deixando explícito o "eu" ao manifestar seu ponto de vista, põe-se a exemplificá-lo em vários momentos da abordagem que faz acerca da temática da prova de redação. Assim, é possível dizer que há presença do "eu", implícita, no texto. 0 movimento que realiza ao manejar a língua e produzir sentido para que lê o seu texto pode ser considerado movimento do sujeito em direção à autoria.

No texto, no desenvolvimento da abordagem, pode-se perceber um sujeito que incorpora outros argumentos para sustentar seu ponto de vista e produzir efeitos de sentido variados. 0 texto contém exemplos de efeitos causados pela implantação da Lei Seca, como o "motorista 
da rodada", a existência de bares que se adaptaram à nova realidade e a parceria com táxis que os estabelecimentos fizeram. Portanto, na redação há um entrelaçamento de discursos variados, o que pode ser visto como manejo da língua de um sujeito autor ao utilizar movimentos enunciativos para constituir-se sujeito e construir sentido, instaurando o "eu" que escreve para o "tu".

0 texto revela a presença de um sujeito enunciador que avalia com discernimento os efeitos positivos da implantação da Lei Seca, exigência da proposta, e ainda consegue abordar com clareza o fato de que há, ainda, pessoas que não foram tocadas pela lei. 0 discernimento com que avalia o que foi proposto e a forma clara de avaliar a questão, em meu entendimento, pode ser sua marca autoral, tendo em vista que o participante, ao introduzir a abordagem já se posiciona a favor da implantação da lei justificando o porquê: com a implantação da Lei as pessoas poderão valorizar mais a vida.

Há uma tomada de posição reforçada pelas marcas expressivas "extremamente", "imprescindível", "infelizmente", "acontece que". No uso desses operadores discursivos existe um sujeito que se posiciona diante do tema. As asserções são traços de construção de autor presentes no texto do participante do ENEM. É a partir delas que o sujeito enunciador se posiciona frente ao tema. É importante dizer, também, que as asserções, presentes em todos os parágrafos da redação são uma maneira que o locutor encontrou de demonstrar o quanto aderiu ao que estava enunciando. Seu posicionamento encontra-se marcado em cada asserção. $01^{\circ}$ parágrafo é inteiramente assertivo.

0 início do $2^{\underline{0}}$ parágrafo parece trazer a voz do enunciador avaliando a certeira decisão da implantação da Lei, quando se lê a expressão "é indiscutível". Em seguida, o texto traz a ideia de que não é costume do brasileiro tomar consciência, por isso, a necessidade de que punições sejam implantadas. Essa afirmação não é apenas expositiva, nem é oriunda de "modelos", pois há nela argumentação. Pode-se dizer que é uma marca de subjetividade presente no enunciado. A meu ver, todas as expressões típicas do gênero dissertação escolar, bem como a afirmação de que as punições sejam implantadas e também em todos os momentos que no texto em questão há construções que pretendam ser imparciais por parte do enunciador, há um tratamento subjetivado da proposta temática. Em outras palavras, há um movimento de autoria presente na enunciação escri- 
ta. Ele advém da relação de tensão entre o que é característica do gênero e exigência do ENEM e a possibilidade de defender um ponto de vista de modo singular, próprio.

A proposta de redação do ENEM/2013 exige que o participante defenda um ponto de vista acerca dos efeitos da implantação da Lei Seca no Brasil. Podemos ver explicitamente a opinião do locutor, por exemplo, na primeira frase do $2^{o}$ parágrafo. Ainda que não haja a presença do "eu", a afirmação é um forte sinal de autoria porque trata do locutor posicionando-se como sujeito e se dirigindo a um outro na tentativa de agir sobre ele, que é o leitor-avaliador.

Em relação ao fato de o "eu" não estar explícito no texto, pode-se dizer, a partir da leitura feita, que o texto cria referência e ela é mantida ao longo da dissertação. Mesmo com a ausência de marcas do locutor, a relação de enunciação é instaurada. Benveniste (1995) afirma que a consciência de si mesmo só é experimentada em contraste. Para ele, a enunciação fornece as condições necessárias de que o locutor pode fazer uso para influenciar o alocutário.

0 3ํ parágrafo traz argumentos incorporados de discursos que estão à volta do sujeito constituído no texto para sustentar seu posicionamento. Ao incorporar argumentos outros e dizer o que o outro disse, o participante usa outras palavras e outras estruturas linguísticas para expressar-se. No desenvolvimento da redação, o sujeito enunciador busca a adesão do interlocutor ao manejar a língua de modo específico, o que pode ser considerado movimento de autoria. São eles a exemplificação e a incorporação de fatos. 0 locutor se apropria da língua para configurar o seu lugar, assumir a língua e enunciar, marcando sua singularidade frente ao "tu" e buscando se inscrever na e pela linguagem.

No 4ํㅜ parágrafo, o locutor parte de fatos para informar que há, ainda, pessoas que não foram tocadas pela implantação da Lei. De modo coerente, ele termina o texto chamando a atenção para a necessidade de a lei atingir a todos. Para isso, propõe ações a serem desenvolvidas em prol de um alcance maior dos benefícios da implantação da Lei e termina o texto chamando a atenção para o fato de que agir implica investimentos e os considera muito importantes para a garantia do direito mais nobre do ser humano, ideia que permeou todo o texto: o direito à vida.

Em relação à unidade e progressão, é possível considerar que, de acordo com Orlandi (1987), o texto apresenta funcionamento de autoria 
porque a progressão funciona como um alicerce para a defesa do ponto de vista que norteia a redação: o efeito maior da implantação da Lei é a valorização da vida.

A leitura da redação permite observar que, para esse participantelocutor-sujeito, a implantação da Lei Seca é extremamente positiva para o país porque já surtiu resultados e porque, assim, muitas pessoas passarão a valorizar mais a própria vida e a das outras.

A singularidade está presente no modo de dizer isso. No texto, os modalizadores apontam a necessidade de campanhas, etilômetros e fiscalização para que a Lei Seca atinja a todos. A construção do texto indica o locutor/participante do ENEM encaminhando sua ação sobre o leitor/avaliador. É, portanto, um forte sinal de autoria se a leitura privilegiar o fato de que na produção da redação o locutor faz escolhas para construir sua referência no discurso. Pode-se dizer que há, então, no texto, uma ação do locutor que se instancia como "eu" para dirigir-se a uma banca de avaliadores. Dentre outros recursos, utiliza pronomes possessivos, formas subjetivas de modalização, marcas de espaço e tempo, na tentativa de marcar como seu o dizer, de constituir-se como sujeito.

Segundo Benveniste (1989), o ato de produzir enunciados ou processo de apropriação da língua por meio de índices específicos e procedimentos acessórios é o que permite a enunciação, ou seja, que converte a língua em discurso. Esse movimento só é possível com a intervenção do locutor. Esse ato individual de utilização da língua para enunciar instaura o "tu" para falar do "ele". Enquanto produto do ato, a meu ver, o modo de conversão da língua em discurso do participante do ENEM contribuiu para a instauração do sentido e pode ser considerado uma construção de autor.

Logo, ao organizar a língua a seu modo, de maneira singular, para expressar seu ponto de vista constituindo-se sujeito, o participante do ENEM se configura como autor, tendo em vista o quadro figurativo da enunciação. Assim, destaco que o olhar enunciativo para a redação analisada permite observar que o participante do ENEM atende à proposta escrevendo o texto a seu modo. Nesse sentido, a leitura enunciativa da redação pode suscitar algumas reflexões. 0 texto foi escrito na terceira pessoa, mas já se inicia com o posicionamento de quem escreve na afirmação de que é dever do governo cuidar da população.

A redação foi elaborada em uma condição figurativa da enunciação escrita. Aquele que escreve almeja, ao produzir o texto, ser avaliado com 
nota que lhe permita ingressar em um curso superior. Ao ler a proposta iniciou-se o quadro figurativo da enunciação. De início, um "eu" dirigiu-se a um "tu" apresentando uma proposta de escrita. Em seguida, o locutor produziu um texto na tentativa de promover uma ação sobre o leitor/avaliador.

$\mathrm{Na}$ leitura e na análise feitas, foram observadas questões relacionadas à subjetividade de que trata Benveniste. Nesse momento, optei por apontar aspectos pontuais, mas é importante ressaltar que há outros movimentos de autoria que poderão ser observados. Por esse motivo, para a avaliação da autoria, deve-se evitar critérios engessados ou se restringir à visualização de marcas linguísticas no texto.

Na redação em análise, não houve utilização da marca "eu" e tampouco foi estabelecido um diálogo direto com o leitor. Isso ocorreu devido ao fato de o participante do ENEM ter sido orientado a optar pela impessoalidade na escrita do gênero dissertação argumentativa quando aprendeu as características do gênero dissertativo argumentativo. No entanto, pode-se dizer que há na redação um locutor instituído em uma relação de intersubjetividade entre o "tu", órgão do governo responsável pelo ENEM e o "tu" que vai avaliar suas redações.

Diante da complexidade que avaliar autoria se apresenta, pretendo me debruçar na reflexão apresentada. A partir da sistematização das análises, buscarei refletir sobre uma maneira de definir mais especificamente o que seja autoria em uma produção de texto.

\section{Conclusão}

Foram apontados, no presente artigo, alguns movimentos da língua em torno da constituição de certo efeito de autoria. Isto é, o candidato que fez a prova do Exame Nacional do Ensino Médio (ENEM) aproveitou a oportunidade para, em condição figurativa da enunciação escrita, expressar sua opinião, atuando como sujeito do discurso.

Por meio da análise da redação com nota máxima em todos os critérios do ENEM e, portanto, configuradora de autoria, percebo que há complexidades quanto ao conceito de autoria e o que se avalia como autoria em se tratando de avaliação de redações. Há também a questão do repertório, que precisa ser estudada com a finalidade de reflexão sobre como ela incide na elaboração do texto do participante do ENEM que precisa expressar, como autor, sua visão sobre o assunto da prova de redação. 
Pensando nisso, ao desenvolver minha tese de doutorado pretendo mobilizar as definições de Benveniste $(1989,1995,2014)$ para propor que enunciação e autoria possam conviver e ser conjugadas em uma teoria do discurso. Dessa forma, que a escrita da redação seja pensada como condição figurativa de enunciação escrita. E que essa escrita, irrepetível, possa ser vista como uma experiência de linguagem, o lugar de sujeito que se constitui na e pela língua como autor do que produz.

\section{Referências}

AGUSTINI, C. L. H; BORGES, S. Z. S. Gênero redação ENEM: a experiência de linguagem em uma escrita institucionalizada. Letras \& Letras, Uberlândia, MG, v.29, n.2, p.1-18, 2013.

ANDRADE, Carlos Drummond. Para gostar de ler. São Paulo: Ática, 1981, v.4, p.6-7. BENVENISTE, Émile. Da subjetividade na linguagem. In: Problemas de linguística geral I. Campinas, SP: Pontes, 1995.

. 0 aparelho formal da enunciação. In: . Problemas de linguística geral II. Campinas, SP: Pontes, 1989.

. Dernières Leçons - Collège de France 1968 et 1969. Paris: Éditions Gallimard e Éditions du Seuil, 2014.

CERVO, Anna. A redação no vestibular: uma análise para além do enunciado. Dissertação de mestrado. São Leopoldo: 2013.

ENDRUWEIT, Magali Lopes. A escrita enunciativa e os rastros da singularidade. Tese de Doutorado. UFRGS, 2006.

KNACK, Carolina. Texto e enunciação: as modalidades falada e escrita como instâncias de investigação. Dissertação de mestrado. UFRGS, 2012.

MELLO, Vera Helena Dantee de. Sintagmatização-semantização: uma proposta de análise de texto. Tese de Doutorado. UFRGS, 2012.

NUNES, Paula Ávila; FLORES, Valdir do Nascimento. A especificidade da enunciação escrita em textos acadêmicos. Revista do Programa de Pós-Graduação em Letras da Universidade de Passo Fundo. Passo Fundo, v.8, n.1, p.235-252, jan./jun. 2012.

ORLANDI, Eni. A linguagem e seu funcionamento: as formas do discurso. Campinas: Pontes, 1987. 


\section{A escrita do relatório: aprendizagem e profissionalização em cursos técnicos de nível médio}

Léa Dutra Costa

A recente expansão da Educação Profissional em todo o país tem chamado ainda mais a atenção para a formação de profissionais de nível médio e incrementado o estudo dos gêneros usados nesse nível de formação. Além disso, é importante considerar que um dos impactos relevantes do Interacionismo Sócio-Discursivo está na ampliação de pesquisas voltadas para os gêneros acadêmicos e entre estes se encontra o relatório. $\mathrm{Na}$ lembrança de muitos profissionais, está o relatório a remexer-lhes a aprendizagem de conteúdos científicos e tecnológicos de tal maneira que a assunção ao discurso acadêmico já se inicia com a escrita de relatórios em cursos técnicos e impactará tanto a atuação no mercado de trabalho como a formação no ensino superior.

Autores consultados sobre a escrita no contexto de ensino de ciências afirmam que ela estabelece uma relação positiva com as capacidades de análise e síntese e com o protagonismo juvenil na vida escolar e social dos aprendizes. Klein e Aller (1998, p.26, apud Souza e Arroio, 2009) asseguram que a escrita é "um modo único de aprendizagem, não apenas valioso, não simplesmente especial, mas único". Especialistas em letramento científico, esses autores veem as "formas tradicionais prescritivas" como um recurso didático-pedagógico capaz 


\section{Léa Dutra Costa}

de propiciar a aprendizagem. Apesar dessa valorização, constata-se, em boa parte das grades curriculares das licenciaturas e bacharelados afins à área das Ciências da Natureza, Matemática e suas Tecnologias, a ausência de disciplinas especificamente voltadas para o ensino da linguagem científica. Essa ausência, muitas vezes suprida pela iniciativa dos professores, pode implicar prejuízo na formação do profissional docente e discente.

Entre os muitos linguistas que se dedicam à aprendizagem e ao papel da escrita no ensino de Língua Portuguesa, Baltar (2004) salienta a escrita como ferramenta capaz de desencadear processos cognitivos, favorecendo a neutralização de fatores conjunturais e a construção de um modelo teórico estrutural do mundo por ser uma forma privilegiada de conferir visibilidade e viabilidade dos pensamentos. Tal perspectiva linguística vai exatamente ao encontro das ideias sobre o papel da escrita como atividade na formação de técnicos, que, aliás, requer conhecimentos científicos e tecnológicos sólidos.

Neste artigo, pretende-se então impulsionar as pesquisas sobre o referido gênero, tendo-se em vista que, na sua utilização como recurso mediador de aprendizagem, encontra-se a proposição de que os relatórios são um instrumento eficaz de ensino-aprendizagem e próprio da atividade profissional do técnico. Objetiva-se descrever e analisar aspectos pedagógicos e linguísticos que podem ser evidenciados a partir da demanda por esse gênero, considerando a relação entre o momento de evolução do desenvolvimento humano de jovens recem-egressos do ensino fundamental e futuros profissionais técnicos e a sua competência discursiva (Baltar, 2004).

Serão focalizados relatórios produzidos por aprendizes do $1^{\mathrm{O}}$ ano do Ensino Médio, após a realização de atividades práticas em laboratório, oficina ou campo, com textos que serão aqui denominados "relatórios de experimento - RE ". A observação empírica do uso de variados modelos de relatório no ensino médio e superior, já realizada por esta autora, os estudos e pesquisas sobre gêneros à luz do Interacionismo SócioDiscursivo e, em especial, as pesquisas a respeito de relatórios e de relatos de estágio na graduação (Gregório, 2003; Silva 2013), contribuíram para que fosse formulada a hipótese de que a demanda por RE, assemelha-se àquela apresentada aos alunos do ensino superior. 


\section{Fundamentação teórica}

A fim de fundamentar adequadamente a demanda por relatórios em cursos técnicos, parte-se do princípio de que se deve buscar uma articulação entre aspectos pedagógicos e linguísticos. Ambos, neste artigo, serão abordados pela perspectiva interacionista.

De um ponto de vista pedagógico, há que se levar em conta a influência e a inter-relação de fatores biológicos, psicossociais e escolares no processo de ensino-aprendizagem (Fernandez, 1991; Pain,1992), que se intensificam no Ensino Médio, cursado, regularmente, na adolescência.

Segundo Knobel (2007), a adolescência é uma fase de instabilidade, cheia de contradições, confusões, ambivalências; é uma fase que vem acompanhada por atritos com o meio familiar e social e por sentimentos de perdas e lutos. Em outras palavras, o adolescente é uma pessoa que vive alterações hormonais e cresce deixando um corpo e comportamentos infantis para trás; uma pessoa que modifica suas relações afetivas, seus interesses e crenças; que enfrenta novas propostas pedagógicas, novos currículos e contratos didáticos, entre tantos outros acontecimentos importantes para o desenvolvimento humano pleno. Para as finalidades deste artigo, é suficiente ressaltar que o adolescente é uma pessoa que, além de embrulhar-se nesses elementos, ou de ser embrulhado por eles, ainda tem que escolher uma profissão (algo bastante difícil até para muitos adultos). Ele também deve, necessariamente, aprender conteúdos científicos e tecnológicos especializados junto a conteúdos do Ensino Médio.

A influência desses elementos é um aspecto do emprego de relatórios na aprendizagem que deve ser considerada linguisticamente, pois, como afirma Bakhtin (2003), há, entre os gêneros, aqueles que são pouco afeitos à expressão de uma identidade e de uma subjetividade e que têm conteúdo temático, estrutura composicional e estilo fixos; aqueles gêneros que são caracterizados por serem menos flexíveis e, por isso, mais estáveis. Tais singularidades fazem dos relatórios um desses gêneros que, a princípio, podem ser vistos como incompatíveis com a adolescência.

Nesse sentido, é essencial considerar que Schneuwly e Dolz (2004) constatam um momento de ruptura no processo de escolarização e aprendizagem da comunidade franco-suíça, o qual ocorre, segundo eles, na passagem do ensino fundamental para o ensino médio, em termos dos níveis 


\section{Léa Dutra Costa}

educacionais brasileiros. Tal acontecimento, de natureza psicopedagógica, pode ser verificado também na educação brasileira, em especial, por professores do $1^{\underline{0}}$ ano do Ensino Médio, série em que diversos problemas de desempenho originam-se nas transformações físicas e psicossociais próprias da adolescência.

Em estudo realizado por Costa e Lima (2010) sobre fatores sociais, afetivos e escolares correlacionados ao baixo desempenho em Matemática, na $1^{\text {a }}$ série em cursos técnicos, as autoras concluem que pequenas diferenças entre as práticas de avaliação de desempenho de um nível de ensino e outro podem ser capazes de determinar retenções e índices de evasão escolar significativos. Se, apenas no ensino médio, essa ruptura já acarreta sérias consequências, o que dizer quando a ele simultaneamente se agregam disciplinas técnicas junto à escolha de uma profissão?

De um ponto de vista linguístico-discursivo, a definição bakhtineana como formas relativamente estáveis no tempo e no espaço, compostas por um conteúdo temático, uma estrutura composicional e um estilo, pertinentes a uma esfera social, subdividindo- se em gêneros primários (diálogos e textos mais típicos da oralidade) e gêneros secundários (romances e gêneros mais característicos do mundo da escrita), é interessante para, de certa forma, entender a adoção do RE. Ele tem a atemporalidade da escrita, é altamente estável e trata de conhecimentos científicos realizados a partir de experimentos; seu estilo é convencional (cabeçalho, introdução, objetivos, procedimentos e métodos, apresentação e discussão de resultados e conclusão ou considerações finais; no RE, privilegia-se o uso da $3^{\mathfrak{a}}$ pessoa e a presença de outras linguagens não verbais). É também próprio de uma esfera social (cursos técnicos, seus professores e alunos). Desse modo, sendo caracterizado como uma forma prescritiva, em linguagem científica, objetiva, precisa e impessoal, acredita-se que o gênero propicia boas condições para que o cidadão desenvolva o ensino de Ciências da Natureza, Matemática e suas Tecnologias como:

um aprendizado útil à vida e ao trabalho [...] de percepção evolutiva da vida, do planeta e do cosmos, enfim, um aprendizado com caráter prático e crítico e uma participação no romance da cultura científica, ingrediente essencial da aventura humana (LDB-MEC, 1996, p.4-7, grifos nossos). 
A escrita do relatório: aprendizagem e profissionalização em cursos técnicos...

Discursivamente, ainda há que se considerar, nesse contexto de ensino, a visão de Bazerman (2005), segundo a qual, entre as características dos gêneros está o seu potencial de fornecer aos membros de uma comunidade as orientações comunicativas e comportamentais das quais devem se dispor para bem se situarem em determinada esfera social. Trata-se, portanto, de ver o emprego por relatórios de experimentos como uma prática de letramento que

pressupõe sujeitos ou grupos sociais que dominam o uso da leitura e da escrita, tendo por isso as condições necessárias para uma participação ativa e competente em situações nas quais práticas de leitura e de escrita têm uma função essencial, do que resulta um certo estado ou condição de inserção em uma sociedade letrada (Soares, 1986, p.34).

Os alunos têm o parâmetro das notas obtidas nos relatórios para lhes orientar a conduta; têm, direta ou indiretamente, indicadores a partir do seu desempenho como um sujeito letrado, ou em letramento em ciências ou até mesmo nada disso. Certos alunos podem concluir que nada sabem nem do ponto de vista científico nem do ponto de vista comunicativo. Quando a produção do gênero faz parte de um sistema de avaliação de desempenho quantitativo, essa impressão de fracasso é bastante comum.

Assim, é importante observar que a escrita de um RE começa e é avaliada, tão logo tem início o ano letivo, ou seja, não é um aprendizado que vai sendo construído ao longo de uma sequência didática. No decorrer do ano, os alunos vão-se adaptando a seu novo contexto de aprendizagem e, na medida em que isso acontece, ocorre também o aprimoramento dos textos produzidos, como mostrado adiante. É relevante perceber, assim, a evolução da competência discursiva dos alunos como é entendida por Baltar (2004): o desenvolvimento de uma capacidade de

mobilizar recursos de vários níveis para, através da produção e recepção de um texto empírico, interagir sócio-discursivamente. Mobilizar esses recursos implica o domínio, o conhecimento e a escolha dos gêneros textuais presentes em um ambiente discursivo; implica o domínio das estruturas estáveis que compõem esses gêneros; implica o conhecimento dos mecanismos de textualização e de enunciação; implica a capacidade de mobilizar conteúdos temáticos tendo em vista o ambiente discursivo 
e as posições de seus interlocutores; por fim implica a capacidade de transferir saberes oriundos de um trabalho de ensino-aprendizagem num ambiente escolar para poder transitar em um ambiente discursivo (Baltar, 2004, p.19).

Nas interações com o professor, com os colegas de turma e com o objeto de estudo, na repetição continuada da mesma atividade de produção de relatórios, os alunos vão-se apropriando naturalmente do gênero; vão mobilizando recursos, dominando estruturas genéricas, colocando em cheque a necessidade de ser o gênero um objeto ensinável. Porém, as dificuldades, que podem surgir da combinação da escrita de um gênero específico com um saber científico, devem ser bem pensadas. Escrever para aprender ciências é uma orientação pedagógica que suscita questões delicadas no que se refere à relação de completude que deve existir entre o conteúdo temático, a estrutura composicional e o estilo próprios de todo gênero, principalmente, quando - grosso modo - ocorre o erro no âmbito do conhecimento científico e tecnológico.

Na análise de relatórios de estágio feita por Silva (2013), encontrase a proposta de que eles sejam vistos como um gênero capaz de promover a prática de uma escrita reflexiva em que o aluno deve: associar a atividade prática ao conteúdo teórico em estudo; produzir textos escritos de acordo com os discursos de cada área ou professor e ter cuidado em escolher a palavra certa no lugar certo; convergência de várias qualidades, utilidades e habilidades, entre essas, a habilidade de articular o experimento com conhecimentos teóricos trabalhados em sala de aula. 0 mesmo ocorre com o RE, que, para os professores, funciona como instrumento mediador ${ }^{1}$ de aprendizagem. Isso significa que eles, ao atribuírem ao relatório à capacidade de colocar-se entre o aluno e o saber científico como uma ferramenta, têm em mente que seus alunos também associam o conteúdo teórico à atividade realizada no laboratório em linguagem científica.

Além desse aspecto, Silva (2013) constata o quanto é variada a demanda por textos escritos na graduação e o quanto fica a desejar o ensino da escrita acadêmica, pois, muitas vezes, os professores esperam tacitamente que os alunos saibam de antemão determinados conheci-

\footnotetext{
${ }^{1}$ Neste artigo, segue-se o conceito vygotskiano para instrumento mediador, vale dizer que o relatório seria um elo intermediário entre o aluno e o conhecimento científico disponível no experimento realizado em laboratório.
} 
mentos que eles (professores) têm, o que nem sempre acontece. Esse quadro de expectativa comum na graduação também é recorrente no ensino médio profissionalizante.

Com relação a isso, é pertinente considerar que o domínio da escrita e da linguagem científica são essenciais para a construção de conhecimentos na área. Torna-se por isso, igualmente essencial, considerar o que Bawarshi e Reiff afirmam a esse respeito:

estudantes com mais dificuldade para escrever [...] 'foram aqueles que ainda não tinham aprendido a traduzir as exigências do professor para determinado gênero em suas próprias palavras' [...] Um dos resultados é que o conhecimento tácito do professor torna difícil articular claramente as expectativas explícitas para o gênero (Bawarshi; Reiff, 2013, p.151).

A partir de Schneuwly e Dolz (2004), é possível pressupor que o RE teria condições de torna-se um "mega instrumento de aprendizagem", desde que devidamente apropriado pelos alunos. Além de todas as ações/ habilidades envolvidas no processo de transformação de uma linguagem que expresse a construção de um saber em texto, é válido considerar que a linguagem de um relatório de experimento é tipicamente multimodal. Como mencionado antes, os alunos devem apresentar em seus textos tabelas, gráficos, figuras, entre outros gêneros que os professores, muitas vezes, esperam que seus alunos já dominem.

\section{Metodologia}

Como este estudo desenvolveu-se a partir da pesquisa de doutorado da autora, seu corpus foi constituído por uma pequena mostra de relatórios produzida por alunos do 1ํano, de uma só disciplina da área das Ciências da Natureza, Matemática e suas Tecnologias, em uma unidade de ensino profissional vinculada a uma universidade pública. Também compuseram o corpus oito entrevistas com os estudantes em 2012 e 2013. Tal disciplina faz parte da grade curricular de todos os cursos oferecidos pela escola, que congrega uma pluralidade significativa de concepções e práticas pedagógicas.

Em uma aula semanal de 100 minutos, de forma alternada, os alunos executavam um experimento e escreviam o relatório correspondente, seguindo um roteiro escrito de orientações, entregue pelo professor para 
a finalidade de elaboração do texto. Além desse material, os alunos foram acompanhados pelo docente, que realizava intervenções na escrita dos alunos quando percebia a presença de erro. Tais intervenções ocorriam sob a forma de questionamentos conforme orientam as metodologias baseadas em resolução de problema. Foram coletados os relatórios correspondentes ao primeiro, segundo e último experimento realizados no $1^{\circ}$ trimestre de 2014 por duas turmas de $1^{\circ}$ ano. Os textos do primeiro experimento foram elaborados sem a participação ou intervenção do professor, que apenas pediu às turmas que escrevessem um relatório do experimento que haviam acabado de fazer.

Tanto o experimento quanto o relatório foram feitos no $1^{\mathrm{o}}$ dia de aula. Nessa situação, os estudantes, individualmente, valeram-se somente dos seus conhecimentos prévios sobre o gênero em uma esfera social, na qual se encontram superpostos o saber escolar e o saber científico. Tais textos foram identificados como "relatório de experimento produzido sem a intervenção do professor" e identificados como "R1".

Para o segundo experimento, os mesmos alunos contaram com o professor na leitura e compreensão de um roteiro escrito que lhes fora entregue no início da aula e que versava sobre o conteúdo e forma de um RE realizado em laboratório. Nele estavam previstas e descritas seis sessões: Introdução, Objetivos, Justificativa, Procedimentos e Métodos, Apresentação e Análise de Resultados e Conclusão ou Considerações Finais, além do Cabeçalho. 0 professor também os acompanhou durante a escrita, atendendolhes às solicitações. Esses textos receberam a denominação de "relatório de experimento após a primeira intervenção do professor" e foram representados pela sigla "R2". Daí até o final do trimestre, todos os alunos escreveram seus relatórios contando com esse roteiro, com o acompanhamento efetivo do professor em sala de aula e com a participação de colegas de grupo. Ao último conjunto de relatórios coletados, deu-se o nome de "último relatório de experimento produzido com a intervenção do professor - R3".

Foram coletados 25 relatórios de experimento sem a intervenção do professor (R1), 19 relatórios após a primeira intervenção (R2) e 14 R3, totalizando 48 relatórios ao final do trimestre, dos quais resultaram 13 sequências compostas por R1, R2 e R3 de cada aluno. A faixa etária do grupo pesquisado foi de 14 a 16 anos e a bagagem de conhecimentos científicos e linguísticos acumulados ao longo da vida escolar era bem variada. Os dados coletados foram analisados a partir da proposta 
de transformação da linguagem em textos orais e escritos, elaborada por Nascimento e Cristovão (2011), embasada na teoria de Bronckart (2003). De acordo com essa proposta, o processo de transformação deve considerar dois níveis de análise: um relativo aos fatos físicos e sociais observáveis no contexto de comunicação - nível sociológico; e o outro, aos fatos relativos à leitura de explícitos e implícitos no texto (fatos do contexto, que constituem o nível psicológico).

O primeiro nível citado é constituído por um conjunto de operações de contextualização (lugar social do agente, finalidade da atividade, relações entre parceiros, os interlocutores, o momento e o lugar da enunciação e por macroestruturas semânticas relacionadas ao conteúdo referencial e disponíveis na memória de cada aluno participante). Esse conjunto de operações forma uma base de orientação para a adoção de um modelo de gênero pertinente para a situação de ação. Já o segundo nível contempla as operações de textualização (operações de ancoragem textual, de referencialidade, de planificação e operações de estratégias linguísticas e discursivas). Da passagem por esses dois níveis resulta um produto final, que as autoras identificam como "texto" e que a autora deste artigo considera ser mais adequado chamar de gênero textual.

Para este artigo, foram considerados apenas os dados do "relatório de experimento produzido sem a intervenção do professor" (R1) e do "relatório de experimento após a primeira intervenção do professor" (R2) de um só aluno.

\section{Apresentação e análise de resultados}

Sob um ponto de vista quantitativo, segundo estimativa inicial, um só aluno de curso técnico regular produz, ao longo dos dois primeiros anos de sua formação, cerca de 60 relatórios. Trata-se de um volume bastante considerável para jovens egressos do ensino fundamental, tal como se pode conferir pelos dados mostrados a seguir.

(1) Número de disciplinas no $1^{\circ}$ ano: duas (Ciências da Natureza: 14 a 16 relatórios anualmente; 6 a 8 relatórios $=20$ a 22 em média).

(2) Número de disciplinas no 2o ano: quatro (Ciências da Natureza e Ciências Exatas: Ciências da Natureza: 28; Ciências Exatas: 20 = 48 em média).

(1) Número de disciplinas com demanda esporádica: indeterminado. 
Conforme esses dados, a média de relatórios produzidos por ano dobra - do primeiro para o segundo ano - de 20 a 22 para 48. Esse fato, quando associado ao $2^{\circ}$ ano, faz pressupor que quanto mais próximo do último ano, mais relatórios podem ser produzidos, ou seja, tanto mais relatórios produzidos quanto mais próximos os estudantes estariam de uma certificação profissional. Em outras palavras, os alunos estariam sendo bem ou bastante preparados para a produção de um gênero característico da esfera de trabalho da qual passariam a fazer parte e para o qual não lhes seria necessário ensino na graduação.

Ainda que a escrit(ur)a possa ser tão dialógica quanto à oralidade, pois alguém (o professor) selecionou algo para outro alguém (os alunos) com quem deseja se comunicar (Antunes, 2010), como instrumento de aprendizagem, a escrita dependerá não só das interações estabelecidas com o outro e o contexto como tão também estará na dependência da relação que cada aluno tem com ela. Um mau desempenho na escrita pode significar ou acarretar um mau desempenho na aprendizagem dos conteúdos científicos; dependerá ainda da relação que o professor tem com a leitura e a escrita, o que poderá ser inferido dos dados e da análise qualitativa que se seguem.

A seguir apresentam-se os relatórios R1 e R2, que serão, logo em seguida, analisados à luz da proposta de transformação da linguagem em textos orais e escritos, elaboradas por Nascimento e Cristovão (2011).

Quadro 1 - Relatório de experimento produzido sem a intervenção do professor (R1).

AAMB27/02/14

Relatório - medida de tempo de reação a estímulos externos

Na aula passada estudamos a medida de tempo de reação a estímulos externos. Para calcular esse tempo fizemos uma roda, e uma pessoa com um cronômetro e essa pessoa aperta a mão de uma pessoa e inicia o cronômetro o cronômetro e cada pessoa começa a apertar a mão da pessoa seguinte até que chegue na pessoa que estava com cronômetro, ai então ela pra o cronômetro.

Como nem sempre dará o mesmo tempo, repetimos essa atividade por 10 vezes e registramos cada valor e tiramos uma média dos tempos obtidos e depois dividimos esse tempo médio pelo número de pessoas que participaram do experimento, chegando assim no tempo de reação aos estímulos externos da sala. 
A escrita do relatório: aprendizagem e profissionalização em cursos técnicos...

Quadro 2 - Relatório de experimento após a primeira intervenção do professor

(R2) Nomes: MC, AAMC, AC

Turma: X

Relatório: Modos Normais de Vibração e Ressonância em cordas

Introdução e Objetivos

Quando dois corpos possuem a mesma frequência e estão conectados um com o outro, eles entram em ressonância, se um deles começar a vibrar. Ao possuir este conhecimento pode-se desenvolver estudos sobre fenômenos sonoros, pois os meios de telecomunicação usam da ressonância para seu funcionamento.

Com base nesses conhecimentos, foi feito um experimento em laboratório com o objetivo de:

- Calcular a que frequência um auto falante entra em ressonância com uma corda;

-Estabelecer uma relação entre a frequência do auto falante e o número de ventres (?) da corda quando esta estiver em ressonância com o aparelho;

Procedimentos e Métodos

Cada grupo tinha um gerador de sinais acoplado a um auto falante em suas mesas;

estes por sua vez estavam conectados a um fio de barbante, assim como na imagem:

Desenho do procedimento

No gerador de sinais há alguns botões que são usados para multiplicar a frequência emitida pelo gerador e um botão que varia a frequência emitida

02 desenhos do aparelho usado: um do botão que varia a frequência e outro do painel do aparelho. 
Primeiramente colocamos o gerador a uma frequência baixa e fomos aumentando-a até que a corda vibrasse. Entretanto, ao continuar a aumentar a frequência, a corda parou de vibrar. Continuamos a aumentar a frequência até chegar no dobro da primeira frequência em que a corda vibrou, mas desta vez a corda vibra com 2 ventres.

\section{Desenho dos ventres}

Colocou-se o triplo da primeira frequência, a corda fez 3 ventres, e assim por diante. Apresentação e Análise de Resultados

Tivemos uma margem, de erro entre as frequências obtidas. A corda vibrava entre $13 \mathrm{hz}$ e $18 \mathrm{hz}, 30 \mathrm{hs}$ e $35 \mathrm{hz}$, entre outros. Foi observado que as frequências obtidas eram múltiplas da primeira. Observou-se também que o número de ventres na corda era diretamente proporcional ao múltiplo da primeira frequência, entretanto está observação pode conter erros devido a faixa em que a frequência se encontrava (5

\section{$\mathrm{Hz}$. \\ Conclusão: Conclusão e considerações finais}

Conseguimos chegar aos nossos objetivos. A corda vibrava inicialmente a $15 \mathrm{~Hz}$ (média dos dados obtidos) e a cada vez que esta frequência era multiplicada aparecia um novo ventre na corda.

Uma análise preliminar desses dois relatórios mostra que as seções Introdução, Objetivos e Conclusão representam a maior dificuldade para os alunos. Nelas ocorrem os problemas relativos ao processo de transformação do pensamento em linguagem materializada; são nelas onde o processo de textualização é mais complexo, onde mais é acionada a competência discursiva dos aprendizes.

Os quadros 3, 4, 5 e 6 mostramos resultado da aplicação da proposta de Nascimento e Cristovão. 
A escrita do relatório: aprendizagem e profissionalização em cursos técnicos...

Quadro 3 - Constituição de uma base de orientação para adoção de RE.

\begin{tabular}{|l|l|l|}
\hline Aspectos analisados & $\begin{array}{l}\text { Relatório de } \\
\text { experimento } \\
\text { produzido sem a } \\
\text { intervenção do } \\
\text { professor R1 }\end{array}$ & $\begin{array}{l}\text { Relatório de } \\
\text { experimento produzido } \\
\text { com a intervenção do } \\
\text { professor R2 }\end{array}$ \\
\hline $\begin{array}{l}\text { O agente se } \\
\text { apresenta como } \\
\text { um sujeito que tem } \\
\text { identidade dentro } \\
\text { de um grupo? Trata- } \\
\text { se da realização de } \\
\text { uma tarefa escolar: a } \\
\text { produção/redação de } \\
\text { um texto? }\end{array}$ & $\begin{array}{l}\text { nome apenas, sem } \\
\text { anotar os nomes dos } \\
\text { colegas de grupo } \\
\text { com quem realizou o } \\
\text { experimento; realiza } \\
\text { a tarefa; trata-se de } \\
\text { um texto escolar e do } \\
\text { gênero relato. }\end{array}$ & $\begin{array}{l}\text { O aluno registra seu } \\
\text { nome e os nomes } \\
\text { dos colegas de grupo } \\
\text { com quem realizou o } \\
\text { experimento; realiza } \\
\text { a tarefa; trata-se de } \\
\text { um texto escolar, já } \\
\text { trazendo evidências de } \\
\text { um relatório. }\end{array}$ \\
\hline $\begin{array}{l}\text { O agente se apresenta } \\
\text { como um "técnico" na } \\
\text { atividade de realizar } \\
\text { um experimento de } \\
\text { laboratório (escolar)? }\end{array}$ & $\begin{array}{l}\text { Não exerce a função } \\
\text { de um técnico; apenas } \\
\text { se coloca como } \\
\text { estudante. }\end{array}$ & \\
\hline
\end{tabular}

Quadro 4-Operações de textualização: relações de ancoragem enunciativa implicada e autônoma; de referencialidade conjunta ou disjunta.

\begin{tabular}{|c|c|c|}
\hline Perguntas & R1 & $\mathrm{R} 2$ \\
\hline $\begin{array}{l}\text { Ancoragem enunciativa } \\
\text { implicada (eixo da } \\
\text { situação material) } \\
\text { A) O agente apresenta } \\
\text { lugar e tempo } \\
\text { imediatos? }\end{array}$ & $\begin{array}{l}\text { A) SIM. Apresenta lugar } \\
\text { social (sala = aula) e } \\
\text { tempo da realização } \\
\text { do experimento } \\
\text { (aula passada). } \\
\text { Obs.: O lugar físico } \\
\text { não é apresentado } \\
\text { (laboratório). }\end{array}$ & $\begin{array}{l}\text { A) } N A \tilde{O} \text {. Dá apenas a } \\
\text { informação de tempo } \\
\text { passado, exceto em } \\
\text { Introdução e objetivos } \\
\text { e indica o lugar físico } \\
\text { (laboratório). }\end{array}$ \\
\hline $\begin{array}{l}\text { O agente apresenta-se } \\
\text { como sujeito imediato? }\end{array}$ & $\begin{array}{l}\text { SIM/NÃO. Inclui-se em } \\
\text { um grupo de pessoas: } \\
\text { nós. }\end{array}$ & $\begin{array}{l}\text { Oscila, ao fazer uso da } \\
3^{a} \text { p. do sing. e da } 1^{\underline{a}} \text { p. } \\
\text { do pl. }\end{array}$ \\
\hline
\end{tabular}

Continua na página 186 
Continuação da página 185

\begin{tabular}{|c|c|c|}
\hline $\begin{array}{l}\text { Ancoragem enunciativa } \\
\text { autônoma (eixo da } \\
\text { situação material) } \\
\text { O agente faz apagamento } \\
\text { do } \\
\text { "eu"? }\end{array}$ & $\begin{array}{l}\text { SIM/NÃO. Aponta a } \\
\text { existência de pessoas } \\
\text { sem detalhar o seu } \\
\text { papel no grupo. }\end{array}$ & $\begin{array}{l}\text { SIM. Faz uso de } \\
\text { impessoalidade. }\end{array}$ \\
\hline $\begin{array}{l}\text { Ancoragem conjunta } \\
\text { (eixo de referencialidade) } \\
\text { O agente sobrepõe o } \\
\text { momento da realização } \\
\text { do experimento com o } \\
\text { da produção do texto: } \\
\text { um mundo (lugar, tempo } \\
\text { e atividade) presente ou } \\
\text { passado? }\end{array}$ & $N \tilde{A} O$ & $N \tilde{A} O$ \\
\hline $\begin{array}{l}\text { Ancoragem disjunta (eixo } \\
\text { de referencialidade) } \\
\text { O agente separa o } \\
\text { momento da realização } \\
\text { do experimento com o } \\
\text { da produção do texto: } \\
\text { um mundo (lugar, tempo } \\
\text { e atividade) presente ou } \\
\text { passado? }\end{array}$ & $\begin{array}{l}\text { SIM. Apresenta/ } \\
\text { explicita o momento } \\
\text { preciso da realização } \\
\text { do experimento: } \\
\text { na aula passada; } \\
\text { apresenta a atividade; } \\
\text { deixa implícito o } \\
\text { lugar da realização do } \\
\text { experimento (outro } \\
\text { lugar diferente da sala } \\
\text { de aula - escola) }\end{array}$ & $\begin{array}{l}\text { SIM. Usa verbos no } \\
\text { passado; identifica } \\
\text { precariamente o lugar } \\
\text { (laboratório) }\end{array}$ \\
\hline
\end{tabular}


A escrita do relatório: aprendizagem e profissionalização em cursos técnicos...

Quadro 5 - Operações de textualização: operações de planificação/ adequação a um modelo de linguagem.

\begin{tabular}{|c|c|c|}
\hline $\begin{array}{l}\text { Aspectos analisados: } \\
\text { presença de elementos } \\
\text { do gênero relatório }\end{array}$ & $R 1$ & $\mathrm{R} 2$ \\
\hline $\begin{array}{l}\text { O aluno apresenta } \\
\text { um Cabeçalho com } \\
\text { identificação e título? }\end{array}$ & $\begin{array}{l}\text { Sim. Apresenta um } \\
\text { cabeçalho precário: } \\
\text { não menciona } \\
\text { os nomes dos } \\
\text { componentes do } \\
\text { grupo de laboratório, } \\
\text { da disciplina e do } \\
\text { professor Apresenta } \\
\text { título. }\end{array}$ & $\begin{array}{l}\text { Sim. Apresentaum } \\
\text { cabeçalho pouco } \\
\text { mais completo: } \\
\text { mencionaos nomes } \\
\text { dos componentes do } \\
\text { grupo de laboratório, } \\
\text { sem mencionar } \\
\text { a disciplina e o } \\
\text { professor Apresenta } \\
\text { título. }\end{array}$ \\
\hline $\begin{array}{l}0 \text { aluno faz a seção } \\
\text { Introdução (resumo } \\
\text { teórico com indicação } \\
\text { do tema e sua } \\
\text { importância)? }\end{array}$ & $\begin{array}{l}N \tilde{A} O \text {. Apenas indica o } \\
\text { tema do experimento. }\end{array}$ & $\begin{array}{l}\text { SIM. Precariamente } \\
\text { menciona o tema } \\
\text { e deixa implícita a } \\
\text { importância. }\end{array}$ \\
\hline $\begin{array}{l}\text { O agente apresenta } \\
\text { a seção Objetivos } \\
\text { (previsão de } \\
\text { resultados a serem } \\
\text { alcançados ou que } \\
\text { deveriam alcançados)? } \\
\text { Menciona objetivo } \\
\text { geral e específico? }\end{array}$ & $\begin{array}{l}\text { Não. Apenas } \\
\text { indiretamente: o } \\
\text { objetivo mencionado } \\
\text { é um objetivo } \\
\text { escolar(estudar); não } \\
\text { faz menção. }\end{array}$ & $\begin{array}{l}\text { SIM. Apresenta } \\
\text { dois objetivos; não } \\
\text { menciona qual seria } \\
\text { o objetivo geral e } \\
\text { qual seria o objetivo } \\
\text { específico. }\end{array}$ \\
\hline $\begin{array}{l}\text { O agente apresenta } \\
\text { Procedimentos e } \\
\text { Métodos (descrição } \\
\text { das ações realizadas } \\
\text { para alcançar o } \\
\text { objetivo)? }\end{array}$ & $\begin{array}{l}\text { SIM. Descreve } \\
\text { o experimento } \\
\text { realizado. }\end{array}$ & $\begin{array}{l}\text { SIM. Descreve } \\
\text { o experimento } \\
\text { realizado. }\end{array}$ \\
\hline
\end{tabular}




\begin{tabular}{|c|c|c|}
\hline & & Continuaçăo da página \\
\hline $\begin{array}{l}\text { O agente faz } \\
\text { Apresentação e } \\
\text { Análise dos dados } \\
\text { obtidos? Apresenta } \\
\text { os resultados } \\
\text { (informações sobre } \\
\text { os fenômenos ou } \\
\text { conceitos que podem } \\
\text { ser interpretados a } \\
\text { partir dos dados)? } \\
\text { Os fenômenos } \\
\text { ou conceitos } \\
\text { apresentados na } \\
\text { Introdução podem } \\
\text { ser vistos através dos } \\
\text { resultados? }\end{array}$ & $\begin{array}{l}\text { Não. Deixa-os } \\
\text { implícitos. }\end{array}$ & $\begin{array}{l}\text { SIM. Precariamente. } \\
\text { Apresenta os } \\
\text { resultados, mas não } \\
\text { os analisa. }\end{array}$ \\
\hline $\begin{array}{l}\text { O agente apresenta } \\
\text { Conclusão: (retomada } \\
\text { dos objetivos do } \\
\text { experimento? Analisa } \\
\text { os resultados? Avalia } \\
\text { a qualidade dos } \\
\text { resultados? Aplica os } \\
\text { resultados ao tema } \\
\text { de estudo/lista ou } \\
\text { conteúdo do roteiro } \\
\text { de perguntas? Faz } \\
\text { ligação do tema com a } \\
\text { realidade cotidiana das } \\
\text { pessoas?) }\end{array}$ & SIM. Precariamente: & $\begin{array}{l}\text { SIM. Retoma os } \\
\text { objetivos e "chegando } \\
\text { assim no tempo } \\
\text { resultados; não } \\
\text { analisa e faz de reação } \\
\text { "; não analisa os } \\
\text { resultados; avaliação } \\
\text { na seção anterior; } \\
\text { resultados; não avalia } \\
\text { a reação; não associa } \\
\text { o tema à qualidade } \\
\text { dos resultados; não } \\
\text { os aplica ao cotidiano } \\
\text { das pessoas. não faz } \\
\text { ligação do tema com o } \\
\text { cotidiano das pessoas. }\end{array}$ \\
\hline
\end{tabular}


Quadro 6 - Operações de textualização: operações de constituição de estratégias linguísticas e discursivas

\begin{tabular}{|c|c|c|}
\hline $\begin{array}{c}\text { Estratégias } \\
\text { analisadas }\end{array}$ & $\mathrm{R} 1$ & R2 \\
\hline Conexão & $\begin{array}{l}\text { Expressão temporal: "Na } \\
\text { aula passada" } \\
\text { Expressão de lugar: "sala" } \\
\text { Expressão de modo/ } \\
\text { conclusão: } \\
\text { "assim" } \\
\text { Expressão de finalidade: } \\
\text { "para" } \\
\text { Expressão de causa: } \\
\text { "Como" } \\
\text { Expressão de adição:"e" }\end{array}$ & $\begin{array}{l}\text { Expressão temporal: "Na } \\
\text { aula passada", "inicialmente" } \\
\text { Expressão de lugar: "sala" } \\
\text { Expressão de modo/ } \\
\text { conclusão: } \\
\text { "assim"; "diretamente" } \\
\text { Expressão de finalidade: } \\
\text { "para" } \\
\text { Expressão de causa: "pois" } \\
\text { Expressão de adição:"e" } \\
\text { Expressão de ressalva: } \\
\text { "entretanto" }\end{array}$ \\
\hline $\begin{array}{l}\text { Coesão } \\
\text { nominal e } \\
\text { verbal }\end{array}$ & $\begin{array}{l}\text { Elipse de sujeito: } \\
\text { estudamos, fizemos... } \\
\text { Ruptura de tempo verbal: } \\
\text { "dará" } \\
\text { Ausência de sujeito: } \\
\text { "Como em sempre dará o } \\
\text { mesmo resultado" }\end{array}$ & $\begin{array}{l}\text { Elipse de sujeito: colocamos, } \\
\text { fomos, continuamos } \\
\text { Ruptura de tempo } \\
\text { verbal: passado/presente } \\
\text { (Procedimentos e Métodos) }\end{array}$ \\
\hline $\begin{array}{l}\text { Vozes e } \\
\text { Modalização }\end{array}$ & Ausência de ambas. & $\begin{array}{l}\text { Vozes: não } \\
\text { Modalização: sim "pode-se } \\
\text { desenvolver"; "pode conter" }\end{array}$ \\
\hline
\end{tabular}

Na constituição de uma base de orientação, a partir do aluno, ao produzir R1 omitindo a informação de que o experimento tinha sido feito coletivamente, pode-se inferir que, naquele momento, ele estaria isolando o escrever (o relatório) do fazer (o experimento). Será que para ele mencionar os nomes dos colegas não tem importância? Será que o experimento foi feito em grupo apenas por motivos logísticos? Para ele, a participação dos colegas na realização do experimento não tem valor? São algumas questões que podem ser levantadas a partir do desempenho do aluno no primeiro dia de aula, apenas com seus conhecimentos prévios sobre o gênero. Em R2, o aluno, além de registrar a participação 


\section{Léa Dutra Costa}

dos membros do grupo, citando seus nomes no cabeçalho, evidencia a transformação de R1 em R2. A atividade parece permanecer como uma atividade escolar, embora não tenha feito mais referência ao meio social, à aula, o que pode indicar alguma mudança no posicionamento do aluno em relação à atividade.

Com relação às operações de ancoragem enunciativa implicada e autônoma, conjunta e disjunta, pode-se afirmar que são mais precárias em R1 do que em R2. Ao não mencionar o lugar e o tempo de forma implicada, o aluno sinaliza que relativizou a importância dessas informações, aproximando-se mais das características genéricas de um relatório de experimento e afastando-se do gênero relato. 0 mesmo pode indicar a oscilação entre a $3^{\underline{a}}$ e $1^{\underline{a}}$ pessoa que o coloca como sujeito imediato da atividade. A ancoragem conjunta e disjunta, apesar de precária, apresenta alguma evolução em R2. Sobressai, no eixo da situação material, a oscilação entre as pessoas do discurso, o que evidencia a problemática da questão do sujeito (autoria) e do fato de ser gênero escolarizado tanto em R1 quanto em R2. 0 aluno passa a fazer, em R2, operações de planificação, fazendo-as, contudo, de forma precária. Ele apresenta, em um mesmo espaço, elementos de uma Introdução a Objetivos, sem distingui-los; apresenta resultados, retoma objetivo, mas não os analisa nem os associa ao cotidiano das pessoas.

As operações de planificação associadas à Introdução, Análise de Resultados e Conclusão parecem apresentar mais dificuldade do que as operações ligadas às demais seções. Observa-se nitidamente o aumento das expressões de conexão, mas a ruptura de tempo verbal, que ocorre em R1 permanece em R2. Apesar de em R2 ainda não serem apresentadas vozes, surgem poucas marcas de modalização. Seria, portanto, pertinente pensar que o aluno agente estaria se apropriando de pelo menos um desses recursos de linguagem importante da elaboração das seções Introdução e Análise de Resultados em especial.

\section{Considerações finais}

Os resultados analisados revelam que, pedagógica e linguisticamente, a apropriação do instrumento de aprendizagem - o relatório, neste estudo - depende dos conhecimentos prévios do aluno, da sua capacidade de trabalhar a competência discursiva bem como das intervenções do pro- 
fessor, sem a exigência da aplicação de uma sequência didática, até mesmo porque pode haver uma lacuna na formação acadêmica do docente em ciências no que diz respeito à escrita e aos gêneros textuais.

Pelas mesmas razões, pode-se inferir que há bons indicadores para que a escrita de relatórios de experimento, como uma prática discursiva, direta e intensamente envolvida na formação de técnicos de nível médio, venha a se revelar uma ferramenta de aprendizagem pouco segura, diante de certa incompatibilidade natural entre o referido gênero e a fase de desenvolvimento humano em que se encontra o aluno: a adolescência. Se o olhar se volta para o futuro do aluno tanto na graduação quanto no trabalho pode-se vislumbrar um resultado positivo, uma vez que ele estará de posse de um conhecimento que seus professores esperam que ele tenha, de uma atividade bastante demandada que caracteriza o domínio da linguagem de uma esfera social.

Ao se voltar o olhar para o presente do aluno, o efeito de sentido que o emprego de um gênero como esse tem sobre um adolescente e sua formação acadêmica poderia implicar um efeito contrário: um "descaminho" para o futuro, não só por ser uma atividade repetitiva e cansativa (conforme dados de entrevistas com alunos), mas também por ser uma atividade que exige domínio da escrita, o que nem todos trazem do ensino fundamental e o que, como esperado, lhes será um grande desafio.

\section{Referências}

ANTUNES, I. Aula de português: encontro e interação. São Paulo: Parábola, 2010.

BAKHTIN, M. Os gêneros do discurso. In: Estética da criação verbal. São Paulo: Martins fontes, 2003.

BALTAR, M. A validade do conceito de competência discursiva no ensino de língua materna. Revista Linguagem em (Dis)curso. L em D, Tubarão, v.5, n.1, (PDF), jul/ dez, 2004. Disponível em: <http://www.portaldeperiodicos.unisul.br/index.php/ Linguagem_Discurso/article/view/308/324>. Acesso em: 2 de maio 2015.

BAWARSHI, A. S; REIFF, M. J. Gênero: história, teoria, pesquisa, ensino. Tradução de Benedito Gomes Bezerra. São Paulo: Parábola, 2013, 285p.

BAZERMAN, C. Gêneros textuais, tipificação e interação. São Paulo: Cortez, 2005.

BRASIL. Lei de Diretrizes e Bases no 9.394, de 20 de dezembro de 1996. Estabelece as diretrizes e bases da educação nacional. Disponível em: < http://portal.mec.gov. br/arquivos/pdf/ldb.pdf >. Acesso em: 10 de maio 2015. 


\section{Léa Dutra Costa}

BRONCKART, J. Atividades de linguagem, textos e discursos: Por um interacionismo sócio-discursivo. São Paulo: EDUC, 2003.

COSTA, L. D; LIMA, Fabíola de O. Perspectiva discente sobre baixo rendimento escolar em matemática na primeira série do ensino médio profissional. In: SIMPÓSIO NACIONAL DE ENSINO DE CIÊNCIAS E TECNOLOGIA, 2, 2010, Ponta Grossa. Anais Ponta Grossa: Revista Brasileira de Ensino de Ciência e Tecnologia, do Programa de Pós-Graduação em Ensino de Ciência e Tecnologia da Universidade Tecnológica Federal do Paraná - PPGECT/UTFPR, Artigo 48. Disponível em: http://www.sinect.com.br/anais2010/artigos/EM/48.pdf>. Acesso em 10 de maio 2015.

CRISTÓVÃO, V. L. L; NASCIMENTO, E. L. Gêneros textuais e ensino: contribuições do interacionismo sócio-discursivo. In: KARWOSKI, A. M.; GAYDECZKA, B.; BRITO, K. S. (Org.). Gêneros textuais: reflexões e ensino. 4ed. São Paulo: Parábola Editorial, 2011, 198p.

FERNÁNDEZ, A. A inteligência aprisionada. Porto Alegre: ArtMed, 1991.

GREGORIO, N. B. Leitura e produção escrita do gênero relatório para desenvolvimento de habilidades. Revistas, 2005. Disponível em: <pucspbr/índex.php/intercambio/article/view/3948>. Acesso em: 12 de maio 2010.

KARWOSKY, A. M; GAYDECZA, B; BRITO, K. S. (Org.). Gêneros textuais: reflexões e ensino. 3ed. Rio de Janeiro: Editora Lucerna.

KLEIN, B; ALLER, B. M. Writing Across the curriculum in college chemistry: A practical bibliography. Language and Learning Across the Disciplines v.2, n.3: April 2535, 1998 apud Souza e Arroio, 2009).

KNOBEL, M. Adolescência e sexualidade. Março 2007. Entrevista concedida à revista Health \& Manegement. Disponível em www.cepps.com.br/item23593.asp. Acesso em maio 2010.

PAIN, S. Diagnóstico e tratamento dos problemas de aprendizagem. Porto Alegre: Artmed, 1992.

SCHNEUWLY. B; DOLZ, J. Gêneros orais e escritos na escola. Trad. e org. de Roxane Rojo e Glaís Sales Cordeiro. Campinas: Mercado de Letras, 2004.

SILVA, R. W. Escrita do gênero relatório de estágio supervisonado na formação inicial do professor brasileiro In: Revista Brasileira de Linguística Aplicada, v.13, n.1, 2013, Belo Horizonte, Faculdade de Letras.

SOARES, Magda B. Linguagem e escola - uma perspectiva social. São Paulo: Ática, 1986.

SOUZA, D. D; ARROIO, A. A questão da escrita, forma e conteúdo, mediada por gênero do discurso escolar-científico nas aulas de Química. VII ENPEC. Florianópolis, 8 de Nov. 2009. Disponível em posgrad.fae.ufmg.br/posgrad/viienpec/pdfs/643. Acesso em jul. 2010. 


\section{Letramento acadêmico no curso de Letras - Português}

Maria de Lourdes Guimarães de Carvalho

Coincidentemente com o processo de democratização do ensino superior, investigações referentes à escrita acadêmica têm sido feitas. Por exemplo, pesquisadores franceses como Boch e Grossmann (2002) atribuem as causas das dificuldades de escrita dos universitários às características específicas de escrita acadêmica. Delcambre e Jovenet (2002), objetivando analisar a prática da escrita na universidade, relacionam essas dificuldades a fatores como: os novos tipos de discurso com os quais os acadêmicos se deparam na universidade, as novas práticas de pesquisa escrita e a distância entre a cultura escrita e as práticas de escrita na universidade.

No Brasil, especificamente com relação às práticas de leitura e escrita de textos do gênero acadêmico por alunos dos cursos de licenciatura, pesquisadores como Assis, Mata e Perini-Santos (2003); Matencio (2006); Motta-Roth e Hendges (2010), não só apontam crescentes dificuldades, mas também afirmam que o gerenciamento das vozes do discurso mostra-se como um ponto crítico das produções dos graduandos.

Tendo em vista essas considerações, o problema de pesquisa que propusemos responder foi: quais são as marcas linguístico-textuais e discursivas que indiciam o letramento acadêmico de alunos do curso de Licenciatura em Letras da Universidade Estadual de Montes Claros Unimontes? Nesse sentido, o objetivo geral foi evidenciar o letramento acadêmico desses alunos. 
Apesar da grande variedade de gêneros do domínio acadêmico, este trabalho está centrado no gênero resenha, particularmente a escrita por professores em formação. Considera-se que é um gênero recorrente no âmbito universitário e deve ser compreendido como auxiliar no desenvolvimento das capacidades de síntese, interpretação e crítica, levando o estudante a pesquisar, ler e elaborar textos científicos mais complexos. É um gênero importante, ainda, para o desenvolvimento da mentalidade científica, e, nesse sentido, suas normas, convenções e modos de escrita deverão ser estudados para que o acadêmico possa, ao produzi-lo, evidenciar seu letramento.

A importância da investigação reside no fato de que, durante a trajetória de formação, os acadêmicos são solicitados a lidarem com diferentes gêneros, seja lendo, seja retextualizando e emitindo suas posições acerca das temáticas estudadas nas diferentes disciplinas do currículo. Sabe-se que características semelhantes à resenha são encontradas em relatos de experiência, artigos, monografias, dissertações, teses, prefácios, apresentações de livros, dentre outros, mais especificamente na seção geralmente intitulada fundamentação teórica ou pressupostos teóricos.

Além disso, como profissionais da área, deverão recorrer a tais ações de forma a contribuir para o letramento de seus alunos. Sobre isso, Mata, ao defender que a leitura e a produção de textos escritos são fundamentais na formação de qualquer graduando, assim afirma: "Em cursos de formação de professores, como é o caso investigado, essa importância é ainda maior já que cabe ao professor a tarefa de inserir outros sujeitos em práticas letradas" (Mata, 2008, p.11).

Há que ser considerado, ainda, que conhecer operações linguísticas e textuais requeridas para a produção da resenha é essencial para o efetivo exercício de construção de autoria do acadêmico, uma vez que a resenha é um gênero que requer, também, posicionamento críticovalorativo, diante dos discursos. Considera-se que o estudante deve não só compreender o que lê, mas também estar ciente de que, conforme afirma Kleiman "[...] a concepção social da escrita implica desenvolver sujeitos plenamente letrados, que têm familiaridade com diversas práticas discursivas letradas de diversas instituições" (Kleiman, 2002, p.34). Nesse sentido, considera-se que, ao praticar a escrita acadêmica, ocorre o uso epistêmico da escrita, que é escrever não apenas para divulgar, mas também para transformar a experiência da escrita em oportunidade para adquirir e para demonstrar conhecimentos. 
Partimos da hipótese de que os ingressantes em um curso de licenciatura não se engajam de imediato nas práticas letradas do domínio acadêmico, já que, nesse novo contexto, são solicitados a ler e a produzir novos gêneros como parte do currículo ou para inserção nos trabalhos de investigação, com os quais ainda não tiveram contato de forma sistemática.

Bakhtin, baseando-se na concepção dialógica da linguagem, defende que o domínio de um gênero é um comportamento social:

São muitas as pessoas que, dominando magnificamente a língua, sentem-se logo desamparadas em certas esferas da comunicação verbal, precisamente pelo fato de não dominarem na prática, as formas de gênero de uma dada esfera. Não é raro o homem que domina perfeitamente a fala numa esfera da comunicação cultural, saber fazer explanação, travar uma discussão científica, intervir a respeito de problemas sociais, calarse ou então intervir de maneira muito desajeitada numa conversa social. Não é por causa de uma pobreza de vocabulário ou de estilo, mas de uma inexperiência, de dominar o repertório de gêneros da conversa social [...] (Bakhtin, 1997, p.303).

Sendo assim, ao ingressarem na universidade, os acadêmicos podem não ser letrados no que se refere ao letramento acadêmico, entendido como a prática de leitura e de produção de um gênero que envolve a utilização de um vocabulário especializado, de novas terminologias e de novos conceitos. Nesse processo, a leitura e a escrita ocorrem com o propósito de aprender por meio da manipulação do exame, da análise, da síntese e da exploração de ideias. Essas atividades concorrem para a construção do conhecimento e a apreensão dos saberes profissionais do futuro professor; entretanto podem se constituir em obstáculo para a aprendizagem imediata. É nesse sentido que abordamos, de forma mais específica, os pressupostos do letramento acadêmico.

0 ponto alto da investigação aqui proposta é que, de posse dos resultados, pretende-se oferecer contribuições para o redimensionamento dos princípios teóricos e procedimentos metodológicos que orientam e definem as atividades de ensino/aprendizagem da leitura e da escrita acadêmica na licenciatura em Letras. Os resultados da investigação poderão, ainda, oferecer indícios sobre possíveis alternativas para se enfrentar a questão do letramento acadêmico nos demais cursos de graduação. 
A abordagem metodológica foi qualitativa. Os instrumentos de coleta de dados foram: um questionário respondido por alunos e professores, entrevista com os professores que aplicaram a resenha e resenhas escritas por alunos do primeiro, terceiro, quinto e sétimo períodos do curso de Letras Português.

\section{Considerações teóricas}

Sabendo-se que as práticas de leitura e escrita são sociais e que delas emergem gêneros de acordo com as necessidades dos grupos com elas envolvidos, há que se considerar a existência de gêneros próprios de cada domínio discursivo. Nesse sentido, os saberes do domínio acadêmico são configurados por gêneros que compõem as práticas sociais desse contexto. Afinal, o contexto universitário é constituído por diversas práticas sociais, das quais emergem diversos gêneros.

Sendo assim, é possível afirmar que, ao conhecer as convenções que regulam as práticas de letramento na universidade, o aluno engaja-se nos modos de uso da escrita valorizados pelas diferentes disciplinas, variedade de áreas temáticas e diferentes situações comunicativas, considerando sua história prévia de letramento e seus valores identitários.

Sobre a aprendizagem de novas linguagens sociais e de diferentes gêneros, Gee (1996) afirma que é um processo que faz parte da socialização. Isso permite inferir que, ao aprender as convenções que regulam um determinado gênero, o estudante, na verdade, está aprendendo novos discursos que integram não só aspectos da língua escrita, mas também aspectos comportamentais, valores, crenças, sistemas simbólicos e tecnológicos, aprendizagens que ativam as identidades sociais dos indivíduos nas práticas sociais nas quais se inserem.

No que concerne à prática da escrita acadêmica, nosso entendimento é de que, anteriormente ao ingresso na universidade, os acadêmicos já percorreram uma trajetória de letramento e já adquiriram valores identitários. A partir daí, deve ocorrer a aprendizagem das convenções que regulam as novas práticas de letramento e o desenvolvimento das habilidades de leitura e de escrita específicas da esfera acadêmica, favorecendo o engajamento nos modos de uso da escrita valorizados pelas diferentes disciplinas e áreas temáticas da instituição.

Coadunamos com uma proposta (Klemp apud Fischer, 2007), que 
afirma que o letramento acadêmico pressupõe um desenvolvimento contínuo de conhecimentos sobre as diferentes formas de interação com os gêneros específicos desse domínio. Assim, tornar-se academicamente letrado implica, em sala de aula do ensino superior, durante toda a trajetória do curso, a utilização de estratégias eficazes que correspondam às diferentes demandas ou práticas sociais do contexto acadêmico.

Fica evidente que o letramento acadêmico diz respeito às "formas particulares de pensar, ser, fazer, ler e escrever, muitas das quais são peculiares a esse contexto social" (Fischer, 2008, p.180-181). Isso significa que um aprendiz academicamente letrado tem um repertório de estratégias efetivas para compreender e usar as diferentes, especializadas e contextualizadas linguagens do domínio acadêmico. Para tal, ele deve desenvolver um repertório de estratégias eficazes e fundamentais para a interação e apropriação dos diferentes gêneros que circulam nesse meio e para a constituição de uma identidade acadêmico-científica e profissional.

Diante desses posicionamentos, fica evidente que a concepção de letramento acadêmico, neste trabalho, é aquela estreitamente relacionada à concepção da escrita como ato social. Essa concepção pressupõe a familiaridade dos sujeitos com as diversas práticas discursivas letradas, especificamente, no que tange àleitura e escrita de textos teórico-científicos que pressupõem normalizações e são primordiais para o desenvolvimento profissional. Consideramos que as habilidades e competências para o letramento acadêmico devem ser desenvolvidas na universidade, durante o curso de graduação.

Importa salientar que, por gêneros acadêmicos, entendemos aqui, aqueles caracterizados, conforme restringe Maingueneau (2005), ora pelo domínio de produção e divulgação de saberes acadêmicos, tais como conferências, palestras, mesas-redondas, comunicações, teses etc., ora pelo suporte material específico, os periódicos acadêmicos especializados (resenha, artigo, ensaio, entrevista, relatório etc.) e, particularmente, as resenhas escritas por professores em formação no Curso de Letras Português.

Isso significa que escrever na academia é um fazer científico e que, para atender às condições de produção dos gêneros acadêmicos, é importante considerar que eles, como os demais, refletem não só suas condições específicas de produção, mas também suas finalidades, conteúdo temático, estilo, especificidades da linguagem como recursos lexicais e gramaticais, e, ainda, normas do texto científico. 
Conforme Schneuwly (2004), os gêneros são produzidos em uma determinada esfera de troca social e escolhidos em função da esfera, necessidades da temática, conjunto dos participantes e objetivos não só da esfera social como também do produtor. Sendo assim, conclui-se que as habilidades de leitura e de escrita de gêneros acadêmicos devem ser exercitadas por meio das experiências vivenciadas pelos acadêmicos, em contato com os aspectos culturais da comunidade discursiva, no caso a comunidade acadêmica.

Nessa mesma linha, para Dell'Isola (2007), a produção de gêneros, na esfera acadêmica, proporciona o diálogo, a interação, a retextualização e é, nesses movimentos de exercício de papéis sociais que ocorre a apresentação de conhecimentos, a avaliação de discursos e, consequentemente, o desenvolvimento das habilidades de leitura e escrita dos gêneros acadêmicos.

Devido à necessária estrutura composicional que caracteriza cada um dos gêneros, a escrita do gênero acadêmico exige o cumprimento de regras gerais que, sabe-se, não podem ser consideradas como algoritmos ou regras fixas, mas que estão momentaneamente estabilizadas, até haver alguma mudança por parte dos órgãos de normalização competentes.

Sobre isso, é importante ressaltar que, muito embora nem todos os textos pertencentes ao gênero acadêmico devam ser estruturados exatamente do mesmo modo, certos elementos são necessários, não só para o enquadramento em determinado gênero, mas também para que o propósito do gênero seja alcançado. Conforme Eggins (1994), a forma como um texto se organiza constitui sua 'estrutura esquemática' que, por sua vez, realiza o potencial do gênero a que pertence. Considerase, assim, que há elementos canônicos, obrigatórios, que facultarão o enquadramento de um texto em um gênero, e elementos opcionais.

Sendo assim, cabe ao professor universitário empreender reflexões acerca das habilidades que deseja auxiliar os alunos a desenvolver. Para tal, ele precisa deixar claros os objetivos das atividades e enfatizar o ensino por meio de um repertório de estratégias de comunicação, atuando como estimulador, crítico, encorajador, enfim, como mediador da aprendizagem.

Finalmente, é importante considerar que os textos que materializam gêneros acadêmicos asseguram o comprometimento do graduando com as práticas e papéis sociais da comunidade discursiva. São produções que apresentam uma linguagem com características diferenciadas e complexas para sua leitura, devendo sê-lo também para sua produção, além de 
exigirem que sejam desenvolvidas outras capacidades que extrapolam a mera organização das formas gramaticais do português padrão.

\section{Panorama do gênero resenha}

Para Maingueneau, um gênero encontra-se submetido a um conjunto de cinco condições de êxito: “a) uma finalidade reconhecida; b) o estatuto de parceiros legítimos; c) o lugar e o momento legítimos; d) um suporte material; e) uma organização textual" (Maingueneau, 2005, p.65-67). Naturalmente na produção do gênero resenha, essas condições variam em intensidade e ênfase, de acordo com os objetivos das diferentes esferas de produção e de divulgação, já que a resenha é um gênero que pode ser produzido em diferentes instâncias, e com objetivos também diferentes.

É assim que, na formação inicial dos professores, entendemos por resenha aquelas solicitadas pelos professores do curso de licenciatura em Letras Português, e em conformidade às respostas da Pergunta 1 Que importância você atribui à leitura e à escrita de textos acadêmicocientíficos? -, do questionário aplicado aos alunos e professores. Para os professores, "[resenhas] são necessárias para a formação profissional, pois promovem a aquisição de novos conhecimentos"; [...] "desenvolvem a capacidade linguística, o senso crítico e a autonomia de pensamentos e opiniões." E, para os alunos “[...] aprimoram e ampliam os conhecimentos, a cultura; aperfeiçoam a escrita e promovem a criticidade e a autonomia de pensamentos e opiniões, melhorando a formação" e “[...] proporcionam o saber científico para a pesquisa".

Logo, na esfera universitária, a resenha é uma oportunidade para que, ao mesmo tempo, os acadêmicos tenham acesso à aquisição de conhecimentos através de leituras e exercitem a produção de conhecimentos através da escrita. É o exercício de leitura e escrita que possibilita ao acadêmico o desenvolvimento de habilidades como descrever, argumentar, discutir, assumir posicionamentos acerca de textos e livros de sua área de estudo, provocar a reflexão e o diálogo com leituras realizadas durante a formação, assim, desenvolvendo a capacidade de atuar crítica e ativamente na comunidade acadêmica.

Assim sendo, ao se estabelecerem as condições de êxito para essas resenhas, é preciso estabelecer que sua finalidade primordial é a demonstração da capacidade de leitura compreensiva e escrita crítica- 
valorativa sobre o texto resenhado. Além disso, são também considerados outros fatores e valores relevantes evidenciados anteriormente por professores e alunos, assim como as respostas dadas pelos professores nas entrevistas realizadas para a verificação das condições de produção, momento no qual houve unanimidade de argumentação, quando afirmaram que o objetivo primeiro da solicitação de escrita da resenha é "motivar para a leitura do texto".

Sobre os interlocutores/enunciatários das resenhas acadêmicas, sabe-se que de um modo geral eles resenham por solicitação do professor e apenas para ele, já que não há, necessariamente, a obrigação de resenhar para divulgação da uma obra e nem de publicação das resenhas produzidas. Já quanto à organização textual, as resenhas devem apresentar características estruturais peculiares, conforme afirma Motta-Roth (2001), já que, caso contrário, enquadrar-se-iam em outro gênero. Contudo, isso não impede que as resenhas incluam, também, o cruzamento de outros interesses discursivos e papéis sociais.

Dessas considerações decorre o fato de que a escrita da resenha deve, obrigatoriamente, surgir do processo de retextualização, o que, necessariamente, implica mudança de propósito, vez que o sujeito opera com novos parâmetros de ação da linguagem. Para Matencio,

retextualizar, por sua vez, envolve a produção de um novo texto a partir de um ou mais textos-base, o que significa que o sujeito trabalha sobre as estratégias linguísticas, textuais e discursivas identificadas no texto-base para, então, projetá-las tendo em vista uma nova situação de interação, portanto um novo enquadre e um novo quadro de referência (Matencio, 2003, p.3-4).

Nessa mesma linha, ao abordar o tema retextualização, Marcuschi pondera que ela é um tipo de alteração marcada pela intervenção na estrutura de um texto, intervenção essa que, segundo ele, assume características diferentes conforme os objetivos que direcionam a nova produção e que estes, por sua vez, são dependentes dos sujeitos envolvidos no processo de retextualizar. Para corroborar essa afirmação, Marcuschi (2001, p.54) apresenta quatro variáveis fundamentais nos estudos dos processos de retextualização: "o propósito ou objetivo; a relação entre o produtor do texto original e o transformador; a relação tipológica entre 
o gênero textual original e o gênero da retextualização; e os processos de formulação típicos de cada modalidade" (Marchschi, 2001, p.54). Marcuschi afirma ainda que:

Atividades de retextualização são rotinas usuais altamente automatizadas, mas não mecânicas, que se apresentam como ações aparentemente nãoproblemáticas, já que lidamos com elas o tempo todo nas sucessivas reformulações dos mesmos textos numa intrincada variação de registros, gêneros textuais, níveis linguísticos e estilos (Marcuschi, 2001, p.48).

Essas considerações permitem afirmar que, neste trabalho, a resenha no curso de Licenciatura é uma atividade de retextualização, entendida como ação de dar origem a um novo gênero (resenha) na modalidade escrita, a partir de outro texto também na modalidade escrita (livro, capítulo de livro, artigo, sempre de natureza teórica ou literária), mantendo a base informacional desse texto, como propõem Marcuschi (2008) e Dell'Isola (2007).

Sendo assim, a atividade de resenhar na academia é estreitamente relacionada com o funcionamento social da linguagem e deve ser executada conforme os propósitos ou objetivos de cada professor que a solicita. Implica a mudança de gênero e dos processos de formulação típicos da modalidade e resulta em uma produção normalmente bem mais extensa do que as resenhas da esfera jornalística que são escritas com a finalidade de publicação e divulgação de obras.

Como em qualquer produção textual escrita, a resenha requer, além da necessária organização estrutural, o exercício de práticas discursivas de leitura e de escrita. Essas atividades são constantemente solicitadas aos acadêmicos, já que operações textual-discursivas, com características semelhantes à resenha, são também encontradas na fundamentação teórica de relatos de experiências, em artigos, monografias, dissertações, teses, prefácios, apresentações de livros, ensaios e outros pertinentes a essa área de estudos e que requerem não só leitura compreensiva, mas também, um posicionamento crítico e valorativo fundamentado.

Nesse sentido, conforme afirma Motta-Roth (1996), resenhar é uma oportunidade para que os escritores inexperientes - no caso, os graduandos - sejam iniciados no debate acadêmico. Já para Bazerman (2006), sendo um agente que participa da estruturação comunicativa acadêmica, 
ao ler ou produzir resenhas, o aluno formaliza seu papel de aprendiz na universidade. Sobre isso, Silva, Assis e Matencio assim se pronunciam:

investir em atividades de retextualização na formação do professor concorre para sua inserção em práticas discursivas do âmbito acadêmico, porque lhe permite, de forma sistematizada, ter acesso a modos de textualização dos saberes (um saber dizer) e apropriar-se de conceitos e procedimentos acadêmico-científicos (um saber fazer) (Silva; Assis; Matencio, 2001, p.1).

Fica evidente que a escrita de resenhas na universidade é uma forma de inserção do acadêmico nas atividades de leitor para aquisição e produção de saberes, o que requer que o aluno exercite e comprove suas habilidades de sujeito letrado. Por envolver tanto a apropriação e sistematização dos saberes científicos, quanto a construção de conhecimentos, a resenha constitui uma estratégia para a complementação da formação docente.

Matencio e Silva (2003), ao fazerem referência à produção de resenhas em contextos de ensino, afirmam que as condições reguladoras são diferentes daquelas em que estão envolvidos os especialistas. Nesse sentido, elas assim se posicionam sobre a resenha no contexto das ações de ensino/aprendizagem:

configura-se como objeto de estudo de crucial importância, por definir-se, a um só tempo, como uma atividade através da qual o aluno pode, de forma sistemática, apropriar-se tanto de saberes relativos ao funcionamento e à configuração textual do gênero como de conceitos e procedimentos teóricos e metodológicos envolvidos na área de conhecimento em estudo (Matencio; Silva, 2003, p.3).

0 resenhista precisa, então, considerar que o contexto é fonte de sentido e ponderar que o entendimento e a produção dependem, em parte, da esfera discursiva na qual o texto é produzido. Entendendo isso, como leitor, o resenhista dá novo significado ao lido e produz, de modo a demonstrar conhecimentos e atender às exigências do contexto de produção. Nesses movimentos, demonstra seu grau de letramento, o que é, certamente, desafiador para o acadêmico iniciante. 
Vale enfatizarque os gênerostextuais são produzidoscom finalidades discursivas específicas e que, para cumprir suas especificidades, cada um deles conta com uma estruturação própria e com recursos de linguagem também específicos. Deve-se contemplar as operações de linguagem que evidenciam o posicionamento enunciativo do resenhista, no que se refere, por exemplo, ao gerenciamento de vozes, responsável pela coerência pragmática e interativa.

\section{Operações de linguagem}

Por operações de linguagem, vale salientar, reportamos aqui àquelas utilizadas pelo autor de um texto e que, conforme Bronckart (2012) são frutos do trabalho social e semiótico de gerações anteriores e estão disponíveis na forma de regras. Para o autor, “[...] essas regras, cristalizadas na intertextualidade de uma língua natural, exercem uma restrição decisiva sobre as operações realizadas na produção de um texto regular" (Bronckart, 2012, p.324), já que definem possibilidades restritas às quais o autor se submete. Isso implica que, ao produzir o seu texto a partir de outro, o resenhador estabelece uma dialogicidade. Ele utiliza estratégias não só para manter-se presente por meio da sua própria voz, mas também para inserir o discurso de outros, movimentos realizados por meio da inserção de marcas da voz do autor resenhado e dos demais autores aos quais ele eventualmente.

Sendo assim, o autor da resenha precisa estabelecer claramente os limites entre as ideias do autor do texto objeto da resenha e as suas próprias ideias. Boch e Grossmann (2002) criam critérios de diferenciação dos modos de referir-se ao discurso do outro, aqui reproduzidos no quadro a seguir. 
Quadro 1 - Critérios que permitem diferenciar os modos de referência ao discurso do outro

\begin{tabular}{|l|l|l|}
\hline \multicolumn{1}{|c|}{ Evocação } & \multicolumn{1}{|c|}{ Reformulação } & \multicolumn{1}{|c|}{ Citação } \\
\hline $\begin{array}{l}\text { Ausência de marcas introdutórias } \\
\text { de discurso reportado (tais como: } \\
\text { segundo X, como afirma X, ou } \\
\text { equivalentes). }\end{array}$ & $\begin{array}{l}\text { Presença de marcas introdutórias do discurso } \\
\text { reportado (segundo X..., de acordo com X...,para } \\
\text { X..., como Xafirma...,como X pretende..., etc.). }\end{array}$ & $\begin{array}{l}\text { Marcas, geralmente escriturais, como aspas, } \\
\text { itálico ou bloco tipográfico, permitem } \\
\text { identificar um segmento do texto como } \\
\text { extraído de uma fonte externa; essas marcas } \\
\text { temático do dizer do outro. }\end{array}$ \\
$\begin{array}{l}\text { Presença de um nome próprio de } \\
\text { autor, frequentemente com data à vezes, ser substituídas por } \\
\text { qual o autor do artigo se refere, sem } \\
\text { precisar o teor do texto. }\end{array}$ & $\begin{array}{l}\text { Ausência de marcas escriturais tais como } \\
\text { aspas (ou verbais, como eu cito X, para } \\
\text { retomar as palavras de X). }\end{array}$ & $\begin{array}{l}\text { comentários metalinguísticos: eu cito X..., para } \\
\text { de quetomaras palavras de X...); } \\
\text { enunciativa. }\end{array}$ \\
\hline
\end{tabular}


Esses entendimentos nos levam a afirmar que, para fins da análise aqui proposta, a evocação, a reformulação e a citação representam recursos que comportam, também, e fundamentalmente, uma dimensão enunciativa. Nela entra em jogo o posicionamento dos interlocutores, indo além, portanto, do que é delineado nos manuais de metodologia científica que, por si só, não são suficientes para tornar os acadêmicos competentes na escrita desse gênero, e, consequentemente, academicamente letrados.

\section{Sistematizando a análise}

De posse das produções, procedemos, inicialmente, ao que chamamos de uma análise textual: leitura atenta para uma visão do conjunto e visualização da estrutura redacional. A seguir, realizamos uma análise temática: leitura com vistas a identificar linha de raciocínio seguida para reconstrução do processo lógico do pensamento do autor, assim como para identificar a compreensão do tema, da ideia central e das ideias secundárias. Finalmente, uma análise interpretativa: leitura para percepção dos detalhes evidenciados como referenciação e contextualização da obra e do autor, percepção dos pressupostos teóricos e filosóficos, relacionamento das ideias do autor com outros autores e com seu próprio entendimento como autor, explicitação do juízo pessoal: avaliação e valoração, etc. Vale enfatizar que, paralelamente à leitura das produções, foi feita a leitura dos textos que deram origem a elas.

Realizadas essas ações, foi possível organizar as produções em quatro blocos distintos, conforme suas especificidades: cópias, resumos, resenhas e outros. Os percentuais de cada turma estão evidenciados no Quadro 2:

Quadro 2: Percentual dos gêneros

\begin{tabular}{|l|c|c|c|c|}
\hline \multirow{2}{*}{ PRODUÇÕES } & 1을 & 3 PER & 5o PER & 70 PER \\
\cline { 2 - 5 } & $\%$ & $\%$ & $\%$ & $\%$ \\
\hline Cópias & 25 & - & 16 & 20 \\
\hline Resumos & 75 & - & 56 & 60 \\
\hline Resenhas & - & 100 & 24 & 20 \\
\hline Outros & - & - & 4 & - \\
\hline TOTAL DE PRODUÇÕES & 20 & 12 & 25 & 10 \\
\hline
\end{tabular}

Fonte: Elaborado pela autora com base nas produções 
Conforme o quadro, os acadêmicos do primeiro período não produziram resenhas, mas cópias e resumos. Esse fato não causa surpresa, porque o estudo da resenha não é contemplado nos anos de escolarização que antecedem o ensino superior. Nas respostas dadas à pergunta seis do questionário, $100 \%$ dos alunos desse período declararam não ter, ainda, escrito resenhas durante o curso.

\section{Movimentos de linguagem: gerenciamento de vozes}

Conforme os critérios que permitem diferenciar os modos de referência ao discurso do outro, conforme Boch e Grossmann (2002), apresentados no Quadro 1, a análise qualitativa das resenhas nos permitiu a verificação da presença de evocação em apenas uma resenha. Quanto ao discurso reportado, detectamos a presença de reformulação em todas as resenhas, de citação em apenas sete e de ilhota citacional em cinco.

\section{Evocação}

Normalmente caracterizada pela presença do nome próprio do autor do texto-base, frequentemente seguido da data da obra citada, sem, contudo, precisar o teor do texto, a evocação apareceu apenas no parágrafo 11 da PROD 2 (3ํㅜ), mas sem as datas da publicação das obras.

RES 2 - 3ㅇ $\mathrm{P}$

§ 11- O Estruturalismo influenciou muito aqui no Brasil. Um dos estudiosos é Joaquim Matoso Câmara Junior que adotou concepções do Estruturalismo Europeu e Americano. Em São Paulo na década de 1960 alguns professores bolsistas recém-chegados da França adotam as leituras de André Martinet, Bernard Pottier, Barthes, Algirdas J. Greimas, além de Saussure.

O fato de ter sido utilizado apenas uma vez e em uma única resenha nos leva a concluir que os alunos têm dificuldade para lidar com esse gerenciamento. Vale salientar que resultados semelhantes foram apresentados em pesquisa realizada por Boch e Grossmann (2002). Eles verificaram a presença da evocação apenas em textos de especialistas, quando comparados a textos de estudantes de letras. 


\section{Reformulação}

Caracterizada pela presença de marcas introdutórias do discurso reportado, sem marcação de aspas ou outro recurso, em que o discurso do outro é integrado no discurso de quem escreve, a reformulação foi, sem dúvida, o modo de referência ao discurso do outro privilegiado pelos acadêmicos na escrita das resenhas analisadas. Provavelmente, isso ocorreu pelo fato de ela ser reconhecida como procedimento não só econômico, mas também facilitador do gerenciamento da voz enunciativa. 0 discurso do autor do texto resenhado foi integrado ao discurso do acadêmico autor da resenha, preservando-se a autonomia daquele, e circunscrevendo, dessa forma, a alteridade enunciativa.

Exemplos de reformulação foram verificados em todas as resenhas de todos os períodos, conforme ilustram os fragmentos abaixo:

PROD 5 - 3ㅇ $\mathrm{P}$

$\S 2$ - $O$ autor aborda neste texto que o estruturalismo teve [...].

$\S 5$ - Segundo Rodolfo a escola [...]. Luis Hjelmsleu valorizou as relações entre as unidades de [...].

PROD $8-3^{\circ} \mathrm{P}$

§ 1- 0 autor descreve a importância do Estruturalismo que teve impacto no Brasil durante os anos de 1960 [...].

$\S 3$ - Segundo Saussure o significado e o significante não teve sua existência relacionados a fatores [...].

PROD 1 - 5ㅇ $\mathrm{P}$

§ 6- No último tópico do capítulo, as autoras descrevem o processo de observação direta extensiva, [...].

PROD $3-5^{\circ} \mathrm{P}$

§3- As autoras explicitam características da Pesquisa Documental [...].

PROD 1 - 7으 P

$\S 1$ - $O$ autor começa seu texto discorrendo sobre [...]. Nunes continua dizendo $[\ldots]$.

$\S 7$ - Para Nunes, o ideal do Manifesto da Poesia [...]. 
Curiosamente raríssimas vezes o acadêmico reformula o discurso do outro, utilizando a forma nome do autor seguido da data de publicação entre parênteses. Entendemos que essa é apenas uma dificuldade técnica que pode ser superada com a interferência do professor, durante o processo de retextualização.

Com o objetivo de ilustrar a reformulação em uma resenha completa, segue a PROD 6:

PROD 6 - 5 $\mathrm{P}$

§ 1- No capítulo 9, do livro Metodologia Científica, Lakatos (2003) e MARCONI (2003), fazem uma abordagem sobre as técnicas de pesquisas essenciais à qualquer ciência.

§ 2-Segundo os autores, as técnicas de pequisas são habilidades para a obtençao de propósitos. [...]. Dessa forma esta pesquisa documental pode ser feita [...]. [...] nesse viés, vem enfatizar também os documentos escritos [...].

$\S 3$ - Depois de fazer uma abordagem da pesquisa documental, os autores relatam sobre a pesquisa bibliográfica [...]. Assim, tem-se fontes de documentos diferentes que requerem procedimentos diferentes, [...]. Este tipo de procedimento requer procedimentos [...].

$\S 4$ - Depois dessa abordagem, Marconi e Lakatos falam sobre a documentação direta que é [...]., e assim pode-se distinguí-la de duas formas: pesquisa de campo e de laboratório.

$\S 5$ - Em consonância com o assunto, os autores ressaltam que a pesquisa de campo está relacionada a observação dos fatos, ou fazer a coleta de dados de determinado fenômeno, mas de forma completa, [...].

§ 6 - Os autores abordam também que a observação direta intensiva pode ser realizada através de duas técnicas: a de observação e de entrevista.

$\S 7$ - [...]. Neste mesmo parâmetro, percebe-se que esta se divide em dois tipos: [...]. Nesta observação sistemática há o que se observar também [...]. 
§ 8 - Depois dessa abordagem da observação, Marconi e Lakatos abordam a questão da entrevista, que segundo estes, consistirá em um encontro entre duas pessoas para se obter informações a respeito de um determinado assunto. Dessa forma, haverá procedimentos de investigação social para a coleta de dados. Nesse âmbito, os autores expõem os objetivos da entrevista, [...].

$\S 9-$ Por fim, os autores ressaltam a questão do questionário [...]. $\S 10$ - Os autores abordaram o assunto de metodologia científica de forma bastante [...].

$\S 11$ - Todos estes aspectos abordados no texto são muito interessantes já que ensinam ao estudante a não perder o foco de sua pesquisa, pois seguindo tais aspectos, pode-se obter um estudo mais interativo [...].

Conforme está explícito nessa resenha, o aluno, ao longo de sua escrita, busca dar ao leitor uma visão geral, porém, esquemática e sequencial do assunto resenhado. Ele faz isso por meio de recursos coesivos que remetem àqueles que se apresentam no material resenhado e que permitem entrever seu posicionamento enunciativo. Para tal ele utiliza as expressões "Dessa forma [...]" e “[...] nesse viés [...]", no parágrafo 2; "Assim [...]" e "Este tipo de procedimento [...]", no parágrafo 3; "Depois dessa abordagem [...]" e "[...] e assim [...]", no parágrafo 4, "Em consonância [...]", no parágrafo 5; "[...] abordam também [...]", no parágrafo 6; "Percebe-se que [...]" e "Nesta observação [...]", no parágrafo 7; "Depois dessa abordagem [...]", “[...] segundo estes [...]" e "Nesse âmbito [...]", no parágrafo 8; e a expressão "Por fim [...]", no parágrafo 9.

A inserção do discurso do outro é feita por meio do discurso reportado utilizando, como recurso, as expressões introdutórias: "Lakatos (2003) e Marconi (2003), faz uma abordagem [...]", "Segundo os autores [...]”, “[...] os autores relatam [...]”, “[...] Marconi e Lakatos falam [...]”, “[...] os autores ressaltam [...]", "Os autores abordam também [...]", "Marconi e Lakatos abordam [...]", “[...] os autores ressaltam [...]", "Os autores abordaram [...]". Desse modo, o autor da resenha mostra que se apoia no autor do texto resenhado. Como não se constrói, no caso em questão, tipo algum de oposição ao que é trazido, pode-se entender que, por meio dos expedientes citados, a resenhista sinaliza que não só coaduna com esse autor, como também adere às ideias por ele explicitadas, além de conferir- 
lhe autoridade. Conforme afirma Maingueneau (2002), essa é também uma forma de criar autenticidade e tornar-se objetivo e sério.

Essas expressões que introduzem o procedimento de reformulação, de querer dizer com as próprias palavras o que o outro disse, proporcionam uma aproximação do ato de pensar, de expressar uma compreensão própria do lido, favorecendo a manifestação de atitudes reflexivas e conscientes, em detrimento do mero exercício de reprodução fiel do dizer do outro.

Com referência ao modo como os estudantes fazem a introdução do discurso do outro, na resenha ilustrativa anterior e nas demais que constituem nosso corpus, nota-se que há uma predileção pelo discurso indireto, em que, conforme Authier-Revuz (2004), o locutor traduz, usando suas próprias palavras, o dizer do outro, remetendo ao outro como fonte do sentido dos propósitos que relata.

Tais expedientes se dão com o uso de verbos dicendi ou do dizer (normalmente utilizados para reportar falas de outras pessoas); no caso das resenhas, o resenhista incorpora à sua a linguagem do autor do texto resenhado, de modo a evidenciar apenas a essência do pensamento deste autor.

De modo geral, os termos introdutores do discurso reportado, nos dados examinados neste trabalho, apareceram no início de parágrafos ou de períodos, iniciados mais comumente com expressões do tipo "o autor [...]" ou com o próprio nome do autor, e, em ambos os casos, seguidos do verbo. Ocorreram, também, na forma de referência pronominal, na forma de elipse (aqui indicada pelo símbolo Ø) em que é possível resgatar o nome do autor anaforicamente com em "Saussure buscou [...], ele utiliza o jogo [...]. Ø utiliza o jogo para contrapor [...]". Os alunos recorrem, ainda, a expressões adverbiais e a termos que remetem à obra resenhada como formas de introdução do discurso reportado. Exemplos podem ser verificados no quadro 3 : 
Quadro 3: Termos introdutórios do discurso reportado

\begin{tabular}{|c|c|}
\hline Tipos & Exemplos \\
\hline \multirow{6}{*}{$\begin{array}{l}\text { Iniciadas com a } \\
\text { expressão "o autor", ou } \\
\text { com o próprio nome } \\
\text { do autor, seguidos do } \\
\text { verbo. }\end{array}$} & O autor inicia seu texto \\
\hline & Hjelmslev explicita essa distinção \\
\hline & Os autores trazem \\
\hline & $O$ autor aborda no texto o... $\varnothing$ Faz-se referência \\
\hline & Rodolfo Ilari trata \\
\hline & $\begin{array}{l}\text { Saussure buscou..., ele utiliza o jogo,... } \varnothing \text { Utiliza o jogo } \\
\text { para "contrapor" }\end{array}$ \\
\hline \multirow{2}{*}{$\begin{array}{l}\text { Iniciadas com } \\
\text { expressões adverbiais }\end{array}$} & Segundo Rodolfo [...]. \\
\hline & De acordo com Nunes, [...]. \\
\hline \multirow{11}{*}{$\begin{array}{l}\text { Iniciadas com termos } \\
\text { que remetem à obra } \\
\text { ou a partes dela, } \\
\text { seguidos de verbo. }\end{array}$} & O primeiro capítulo [...] retrata [...]. \\
\hline & O capítulo em questão termina destacando [...]. \\
\hline & O sexto e último capítulo da obra diz respeito [...]. \\
\hline & O presente capítulo II aborda [...]. \\
\hline & O oitavo tópico intitulado [...] trás [...]. \\
\hline & A outra parte do texto vai tratar [...]. \\
\hline & A linguística estrutural também trouxe [...]. \\
\hline & No tópico 9.12, inicia-se a [...]. \\
\hline & No segundo tópico do capítulo IX, trata-se de [...]. \\
\hline & O texto: aborda [...]. \\
\hline & Essa obra: tem grande valor, [...]. \\
\hline
\end{tabular}

Fonte: Elaborado pela autora.

Como é possível notar, há passagens em que são usadas expressões adverbiais, introduzindo um discurso quase sempre parafraseado e, muito raramente, com a tentativa de citação literal. Essas marcas também garantem a responsabilidade pelo dito ao próprio autor do texto resenhado, contando, evidentemente, com o respaldo do autor da resenha, na medida em que este é que traz o dizer de outrem. 
Ocorreu, também, certo ocultamento da voz do autor resenhado, por meio de recursos em que a origem do dito é atribuída ao próprio livro, capítulo ou às suas partes. Com as expressões indicativas de partes da obra (capítulo, tópico), ou mesmo de partes do assunto (A linguística estrutural [...]), seguidos dos verbos na terceira pessoa do singular acompanhados ou não do pronome "se", o resenhista mantém uma impessoalidade em relação ao dito, colocando-se à distância.

Ainda com relação aos recursos de introdução ao discurso do outro, é interessante salientar que, nas vinte produções classificadas como resenhas, ocorreram 75 verbos diferentes, dos quais 43 foram utilizados apenas uma vez. Os alunos elegeram como preferidos os verbos "abordar", no sentido de falar sobre (14 vezes) e "ressaltar", no sentido de pôr em evidência ( 9 vezes). Os demais aparecerem em uma pequena quantidade de vezes, sendo a maioria deles (43), apenas uma vez.

Pode-se dizer que tais verbos revelam uma atitude interpretativa do resenhista, em relação ao que se retextualiza. Além disso, são verbos que indicam, de algum modo, o efeito (perlocucional) que o autor da resenha queria provocar no destinatário, ou seja, um efeito responsivo, como um convite ao compartilhamento com ele da tarefa de levar adiante as ideias apresentadas. Ao mesmo tempo, ele se exime de assumir, por sua conta, a responsabilidade enunciativa e o que realiza é um trabalho interpretativo, atribuindo ação, acontecimento, atividade mental etc., ao autor do texto resenhado.

\section{Citação}

Esse recurso de linguagem é visto como uma estratégia discursiva que reporta à voz do autor do texto resenhado (como autoridade), criando um efeito de realidade, de modo a dar a impressão de que a instância geral da enunciação apenas repete o que diz a voz reportada. Dessa forma, a citação cria um espaço autônomo no plano enunciativo. Conforme esclarecem Boch e Grossmann (2002), marcas, geralmente escriturais, como aspas, itálico ou bloco tipográfico, permitem identificar um segmento do texto como extraído de uma fonte externa. Essas marcas podem, às vezes, ser substituídas por comentários metalinguísticos do tipo “Cito X [..], para retomaras palavras de X [...]", recursos não utilizados nas resenhas analisadas. 
A citação deve, conforme afirmam Boch e Grossmann (2002, p.107), ser compreendida, "[...] como gesto paradoxal de inserção de um discurso que é, quase sempre, radicalmente outro (em seu vocabulário, em seu estilo, pelos espaços teóricos que abre), dentro de um discurso tateante, às vezes disforme, mas no qual eles aprendem a se constituir como sujeitos".

Nesses termos e conforme já explicitado, é desejável que a citação seja utilizada como uma forma de apoio à construção enunciativa do resenhista, processo que nem sempre ocorreu, de forma satisfatória, nas resenhas analisadas. Por exemplo, nos parágrafos transcritos abaixo, as passagens identificadas como modos de referir-se ao discurso do outro estão em negrito e, por seu intermédio, o resenhista insere citações.

PROD 2 - 5으

$\S 2$ - As autoras apontam a importância da técnica em um estudo e a define: “Técnica é um conjunto de preceitos de que se serve uma ciência ou arte; é a habilidade para usar esses preceitos ou normas, a parte prática. Toda ciência utiliza inúmeras técnicas na obtenção de seus propósitos". (Lakatos; Marconi, 2003, p.174).

§ 7- Em seguida é apresentada a parte bibliográfica da pesquisa. "Da mesma forma que as fontes de documentos, as bibliográficas variam, fornecendo ao pesquisador, diversos dados e exigindo manipulação e procedimentos diferentes". (Lakatos; Marconi, 2003, p.183).

PROD $5-5 \div \mathrm{P}$

§ 8- [...]. Com referência à Bateria, a autora afirma que "é uma série de perguntas que têm a finalidade de aprofundar algum ponto importante da investigação e do questionário ou formulário.".

§9- Lakatos também cita três qualidades essenciais de todo formulário, apontadas por Ander-Egg (1978:125): “Adaptação ao objeto de investigação; adaptação aos meios que se possui para realizar o trabalho; precisão das informações em um grau de exatidão suficiente e satisfatório para o objetivo proposto".

Por meio das citações, o resenhista apoia-se no dizer do outro, de forma acriar um espaço autônomo no plano enunciativo. Há, nesses casos, uma reprodução fiel de trechos com falhas em detalhes da técnica normativa de citação, que podem ser sanados com pesquisas e discussões metodológicas.

Conforme Boch e Grossmann (2002), a citação aparece nas produções acadêmicas como palavras emprestadas favorecedoras da 
assunção da própria voz, das próprias escolhas, implicando o exercício das habilidades de dialogar com o autor e com o texto/assunto para, desse modo, demonstrar a capacidade crítica e ativa de leitor e produtor de textos, refletindo, evidentemente, seu grau de letramento.

Na PROD 3 (5ํㅜ), o aluno tenta fazer citação autônoma:

\begin{tabular}{|c|c|}
\hline PROD 3 (5우 $)$ & LAKATOS e MARCONI (2003, p.213) \\
\hline $\begin{array}{l}\S 21 \text { - Na } \\
\text { última página } \\
\text { do capítulo } \\
\text { IX, alguns } \\
\text { aspectos para } \\
\text { a apresentação } \\
\text { do formulário } \\
\text { como o tipo, } \\
\text { o tamanho, } \\
\text { deve ser } \\
\text { datilografado, } \\
\text { mimeografado } \\
\text { ou impresso em } \\
\text { uma só face do } \\
\text { papel, uma vez } \\
\text { que "causam } \\
\text { má impressão, } \\
\text { formulários } \\
\text { antiestéticos", } \\
\text { de acordo com } \\
\text { Witt (1973:46). }\end{array}$ & $\begin{array}{l}\text { A observância de alguns aspectos é necessária na } \\
\text { construção do formulário, para facilitar o seu manuseio e } \\
\text { sua posterior tabulação. } \\
\text { Deve ser levado em conta o tipo, o tamanho e o formato do } \\
\text { papel; a estética e o espaçamento devem ser observados } \\
\text { e cada item deve ter espaço suficiente para a redação das } \\
\text { respostas. Os itens e subitens precisam ser indicados com } \\
\text { letras ou números e as perguntas ter certa disposição, } \\
\text { conservando distância razoável entre si. Deve ser } \\
\text { datilografado, mimeografado ou impresso em uma só face } \\
\text { do papel. É importante numerar as folhas. } \\
\text { As formas de registro [...]. } \\
\text { A redação simples, clara, concisa é ideal. Itens em } \\
\text { demasia devem ser evitados. "Causam má impressão } \\
\text { questionários ou formulários antiestéticos em termos de } \\
\text { papel, disposição das perguntas, grafia etc.", afirma Witt } \\
\text { (1973: 46). }\end{array}$ \\
\hline
\end{tabular}

Ao comparar o excerto da PROD 3 (5ํㅜ) com fragmentos do textobase, nota-se que falta um critério para a escolha do que deve ser citado. As lacunas deixadas pelo acadêmico prejudicam a compreensão do escrito e demonstram que a leitura não foi bem-feita. Ele apenas condensa partes do texto que deu origem à resenha. Em seu parágrafo, ele não assegura os aspectos que causam má impressão. Além disso, ao fazer referência quanto ao tipo e ao tamanho, ele não assegura os demais itens abarcados por Witt. Ademais, o correto seria dizer (Witt apud Lakatos; Marconi, 2003, p.213), já que é uma citação de citação, caracterizando a inserção de uma voz que não é a do autor do texto resenhado, conforme ensinado na disciplina Metodologia da Pesquisa Científica, ministrada no $1^{\circ}$ período. 


\section{Ilhota citacional}

Por meio desse recurso, o aluno ressalva a referência ao discurso reportado, destacando-o com aspas, mas integra seu ponto de vista ao do autor. Exemplos podem ser vistos destacados nos fragmentos a seguir:

PROD $9-3$ - $\mathrm{P}$

§ 4- A língua [...] já a fala é a língua posta em ação, e por ser um ato individual faz alusão aos possíveis usos do sistema, isto é, da língua, essa distinção chega-se a mais fundamental das oposições saussurianas conhecidas como "oposição língua/fala" ou "oposição langue/parole,"[...].

§9- O Funcionalismo orientou a França nos anos anteriores ao Estruturalismo, e contribuiu para que a França se identificasse com tal corrente, reafirmando a "dupla articulação da linguagem - estabelecendo que haveria em toda língua natural dois níveis de oposição" (p.72), [...].

$\S 12-[. .$.$] foi escolhida apenas uma variedade de tantas outras como padrão$ devido aspectos de classe social e estética, dando atenção também aos fatos falados, representando um avanço em relação ao Estruturalismo, todavia, "não seriam possíveis sem ele" (p.89).

PROD 2 - 7으 $\mathrm{P}$

§7- 0 ideal do manifesto Pau-Brasil é harmonizar duas pontes não antagônicas, a cultura nativa e a intelectual renovada; "o melhor de nossa tradição lírica com o melhor de nossa demonstração moderna". Em fim, Nunes encerra essa primeira parte fazendo apologia à visão poética Pau-Brasil e ao Pensamento Selvagem os quais estão associados às correntes de vanguarda oswaldiana.

De um modo geral, constatou-se a escassez do discurso reportado, seja por meio de reformulação, citação ou ilhota citacional e, é comum a ocorrência de falhas no modo como os acadêmicos utilizam esses recursos. Entendemos que esses fatores refletem a falta de habilidade para empreender o processo de retextualização, e são fortes indicativos de que os acadêmicos ainda não alcançaram um grau elevado de letramento acadêmico.

\section{Considerações finais}

A análise das produções possibilitou-nos a compreensão de que são visíveis as dificuldades dos acadêmicos na escrita do gênero resenha. Em primeiro lugar, a dificuldade é referente ao desafio de compreender a 
natureza do gênero e não de redigir um resumo ou simplesmente recorrer a ações de cópia, já que apenas $29,85 \%$ das produções puderam ser enquadradas como resenhas.

Em segundo lugar, verificamos que há problemas no estabelecimento dos limites de um posicionamento autoral consistente, levado a termo por meio do emprego dos mecanismos enunciativos que contribuem para a coerência pragmática da produção. Nem todos os acadêmicos apresentaram, com segurança, o domínio do gerenciamento de vozes necessário à indicação do posicionamento autoral do resenhista, de forma a estabelecer limites claros entre suas ideias, as do autor do texto resenhado e as de outros autores cujas vozes se entrecruzam nesse texto.

Entendemos que, quando se limitam a reproduzir as vozes já ditas pelo autor do texto resenhado ou de outros por ele citados, os acadêmicos demonstram a necessidade de um redimensionamento das práticas de ensino do texto acadêmico no curso em que os dados foram coletados. Necessário se faz a assunção de um compromisso sistemático não só com as questões estruturais, mas, sobretudo, com as práticas de linguagem precisamente no que se refere ao gerenciamento de vozes peculiar ao gênero.

Concluímos que o trabalho do professor com o ensino/aprendizagem da leitura e produção de textos acadêmicos, visando ao letramento acadêmico seria mais bem desenvolvido sob a perspectiva do Interacionismo Sócio-discursivo. Essa teoria considera o texto como a materialização de uma ação constituída por uma série de operações de linguagem que, necessariamente, devem ser vistas pelos agentes da prática de formação universitária como um conjunto de operações que envolvem a linguagem, constituindo uma unidade, cuja responsabilidade de realização é atribuída ao indivíduo. Este, por sua vez, é movido por motivos e orientado por objetivos, no momento de interlocução social.

No âmbito de um curso de licenciatura, o objetivo do professor deve, assim, ser o de proporcionar ao acadêmico o domínio dessas operações de linguagem para que ele possa desenvolver a capacidade necessária para agir. Tendo em vista que essas ações, operações e capacidades não são inatas, cabe ao professor colaborar para que seu aprendizado ocorra.

Consideramos que a atividade de escrita de resenhas é uma oportunidade para o contato com as diferentes operações de linguagem que, certamente, influenciarão na leitura e produção dos demais textos da es- 
fera acadêmica. Desse modo, é uma atividade que conduzirá o aluno da graduação ao letramento acadêmico.

Somos de parecer que, mais do que ensinar sistematicamente a estrutura do gênero resenha, e certamente de outros gêneros do domínio acadêmico, é importante, e necessário, no ensino superior, a discussão sobre os recursos de linguagem exigidos para a produção desses gêneros. 0 gerenciamento de vozes, por exemplo, é tão importante para o processo de ensino e aprendizagem da leitura quanto para o ensino e aprendizagem da produção de textos, uma vez que proporciona ao aluno a oportunidade de ser o autor de seu próprio texto e agente da ação da linguagem. Consideramos que é no eficiente trabalho com a linguagem que é possível desenvolver a identidade acadêmica, de forma a proporcionar a competentização para o enfrentamento das situações que são requeridas a um sujeito academicamente letrado.

Com essa orientação, possibilitar-se-á ao estudante decidir sobre o conteúdo temático a ser semiotizado, escolher um modelo de gênero adaptado à sua situação de comunicação, selecionar e organizar os tipos de discursos, bem como gerenciar os diversos mecanismos de textualização. Se assim for, se tornará responsável pelo que escreve e passará a ser agente da linguagem, autor do seu texto, e, academicamente letrado.

Como a investigação não é exaustiva, sugerimos que outras pesquisas referentes à produção de textos e ao letramento acadêmico sejam desenvolvidas no âmbito do curso. Somos de parecer que, se os alunos da graduação apresentam dificuldades para inserir as vozes na resenha, ao relatarem o discurso do outro, dificuldade igual devem sentir para redigir os demais gêneros acadêmicos.

\section{Referências}

ASSIS, Juliana Alves; MATA, Maria Aparecida da. PERINI-SANTOS, Pedro. Ensino aprendizagem de resumos acadêmicos em sala de aula: negociação de representações. In: ENCONTRO INTERNACIONAL DE LINGUAGEM, CULTURA E COGNIÇÃO: REFLEXÕES PARA O ENSINO, 2, Campinas, SP: Anais, Graf. FE ALB, 2003.

BAKHTIN, M. Marxismo e filosofia da linguagem. São Paulo: Hucitec, 1997.

BARTON, D. Literacy: an Introduction to the ecology of written language. London: Blackwell, 1994

BARTON, D.; HAMILTON, M. Local literacy: reading and writing in one community. London and New York: Routledge, 2000. 
BOCH, Françoise; GROSSMANN, Francis. Referir-se ao discurso do outro: alguns elementos de comparação entre especialistas e principiantes. Trad. Maria de Lourdes Meirelles Matencio. Scripta, Belo Horizonte, v.6, n.11, p.97-108, 2º sem. 2002.

BRONCKART, Jean-Paul. Atividades de linguagem, textos e discursos: por um interacionismo sociodiscursivo. Tradução de Anna Rachel Machado e Péricles Cunha. 2ed. São Paulo: EDUC, 2012.

DELCAMBRE, Isabelle; JOVENET, Anne-Marie. Lire-écrire dans le supérieur. Spirale, n.29, 2002.

DELL'ISOLA, R. L. P. Retextualização de gêneros escritos. Rio de Janeiro: Lucerna, 2007.

EGGINS, Suzanne. An introduction to systemic functional linguistics. London: Pinter, 1994.

FISCHER, Adriana. A construção de letramentos na esfera acadêmica. 2007, $340 \mathrm{f}$. Tese (Doutorado em Linguística)- Universidade Federal de Santa Catarina. Florianópolis. Disponível em: <http://www3.unisul.br/paginas/ensino /pos/linguagem/cd/ Port/3.pdf>. Acesso em: 21 abr. 2012.

FISCHER, Adriana. Letramento acadêmico: uma perspectiva portuguesa. Acta Scientiarum. Language and Culture, v.30, n.2, p.177-187, 2008.

GEE, James Paul. Social linguistics and literacies: ideology in discourses. 2.ed. London: Taylor e Francis, 1996.

KLEIMAN, Ângela B. Ação e mudança na sala de aula: uma pesquisa sobre letramento e interação. In: ROJO, Roxane (Org.). Alfabetização e letramento: perspectivas linguísticas. Campinas, São Paulo: Mercado das Letras, 2002.

MAINGUENEAU, Dominique. Novas tendências em análise do discurso. Belo Horizonte. UFMG, 2005.

MARCONI, Marina de Andrade; LAKATOS, Eva Maria. Fundamentos de metodologia científica. 5ed. São Paulo, 2003.

MARCUSCHI, L. A. Da fala para a escrita: atividades de retextualização. São Paulo: Cortez, 2008a.

MARCUSCHI, L. A. Produção textual, análise de gêneros e compreensão. São Paulo: Parábola Editorial, 2008b.

MATA, Maria Aparecida da. Processos referenciais na retextualização de textos acadêmicos:Faculdade de Letras da UFMG. 2008, 174f. Tese (Doutorado)- Universidade Federal de Minas Gerais, Programa de Pós-Graduação em Estudos Linguísticos.

MATENCIO, Maria de Lourdes Meirelles. Letramento na formação do professor integração a práticas discursivas acadêmicas e construção da identidade profissional. In: CORRÊA, Manoel Luiz G.; BOCH, Françoise. (Org.) Ensino de língua: letramento e representações. Campinas: Mercado de Letras, 2006. 
MATENCIO, Maria de Lourdes Meirelles. Referenciação e retextualização de textos acadêmicos: um estudo do resumo e da resenha. In: CONGRESSO INTERNACIONAL DA ABRALIN, 3, 2003, Anais..., mar. 2003.

MATENCIO, Maria de Lourdes Meirelles; SILVA, Jane Quintiliano Guimarães. Retextualização; movimentos de aprendizagem. ENCONTRO INTERNACIONAL LINGUAGEM, CULTURA E COGNIÇÃO, 2, 2003. Belo Horizonte/Campinas, Faculdade de Educação da UFMG/Faculdade de Educação da UNICAMP, Anais..., Belo Horizonte/ Campinas: Faculdade de Educação da UFMG/Faculdade de Educação da UNICAMP, 2003.

MEDEIROS, J. B. Redação científica: a prática de fichamentos e resenhas. São Paulo: Atlas, 2000.

MOTTA-ROTH, Désirée. Redação acadêmica: princípios básicos. Santa Maria, RS: UFSM/ Imprensa Universitária, 2001.

SCHNEUWLY, Bernard. Gêneros e tipos de discurso: considerações psicológicas e ontogenéticas. In: SCHNEUWLY, Bernard. Gêneros orais e escritos naescola. Tradução e Organização de Roxane Rojo e Glaís de Sales Cordeiro. Campinas, SP: Mercado de Letras, 2004, p.21-39.

STREET, Briani V. Literacy in theory and practice. London: Cambridge University Press, 1984. 


\section{Escrevendo na e para academia: um estudo sobre a incorporação do discurso acadêmico no gênero relato de experiência}

Roberta Andrade Meneses

Williany Miranda da Silva

Nas últimas décadas, tem-se notabilizado um crescente interesse no tocante aos estudos enfocando a produção escrita de textos acadêmicos, tais quais: projetos de pesquisa, artigos científicos, resenhas acadêmicas, Abstracts, dentre outros (Motta-Roth; Hendges, 2010). Essas produções materializam um conjunto de normas tácitas ou mesmo explícitas impostas pela comunidade acadêmico-científica, caracterizada por assumir uma ordem do discurso particular, muitas vezes estranha aos seus membros neófitos.

Tendo em vista tal realidade, este trabalho tem por objetivo depreender que estratégias os sujeitos graduandos, inseridos em contexto de produção de texto especializado, mobilizam para integrarem-se à comunidade discursiva acadêmica. Conforme Swales (1990), a noção de comunidade discursiva diz respeito à ideia de um grupo de indivíduos partilhando objetivos públicos comuns (há também os interesses particulares - implícitos ou explícitos). Esses indivíduos, ao ligarem-se por interesses, práticas e atividades em comum, utilizam-se de convenções discursivas específicas, atestadoras da identidade do grupo, de modo que seus discursos revelam os conhecimentos partilhados (Swales, 1990). 
Orientada pelo paradigma interpretativista, de viés documental, nossa pesquisa compreendeu a análise de um corpus constituído por vinte exemplares do gênero relato de experiência, produzidos no âmbito da disciplina Estudos de Oralidade e Escrita, por graduandos recémingressos no curso de Letras de uma universidade pública federal. A partir disso, promovemos um recorte no corpus, elegendo a unidade retórica referente à Apresentação da experiência - introdução, de dois dos relatos coletados, um que atende ao esperado para esse gênero, outro que não, sendo ambos os sujeitos produtores pertencentes ao $2^{\circ}$ período do curso de Letras.

Desse modo, foi possível depreender que os produtores utilizaram-se de diferentes estratégias para a produção do texto especializado, evidenciando, consequentemente, ocuparem diferentes estágios de desenvolvimento de escrita acadêmica, bem como de apropriação do discurso acadêmico-científico.

Com vistas a atender ao que nos propomos, o plano organizacional deste trabalho apresenta, além desta introdução, as seguintes seções: 1 - Letramento acadêmico: uma linguagem social específica, 2 Desenvolvimento de escrita: a aquisição de conhecimentos e 3 - Escrevendo na e para a academia o gênero relato de experiência, referentes à apresentação e discussão dos subsídios teóricos utilizados. Na seção 4, Unidade 1 - Apresentação da experiência, damos início à análise dos dados; seguida das conclusões, e, por fim, das referências utilizadas no trabalho.

\section{Letramento acadêmico: uma linguagem social específica}

A compreensão do letramento como uma prática social situada, a qual só se notabiliza a partir dos significados políticos e ideológicos que assume (Street, 2010), marca um novo plano conceitual no modo como a escrita é concebida, trata-se dos Novos Estudos do Letramento (Street, 1984; Barton, 1994; Barton; Hamilton, 2000; Gee, 1996, 2001).

Conforme essa perspectiva, a escrita passa a ser tomada considerando-se seus usos sociais, que se orientam segundo práticas culturais discursivas, dependentes do contexto e seus arranjos sociais. Nesse sentido, o letramento é um fenômeno situado, adquirindo significados a partir das funções que assume em dada formação social. 
Escrevendo na e para academia: um estudo sobre a incorporação do discurso...

Em se tratando da esfera acadêmica, temos a noção de letramento acadêmico, que pode ser entendida, sob uma perspectiva geral, como a capacidade de ser fluente em modos de pensar, ser, fazer, ler e escrever nessa esfera de atividade humana (cf. Fischer, 2008).

Tal fluência envolve a mobilização de conhecimentos de ordem formal e discursiva para a produção de gêneros típicos. Em outras palavras, escrever academicamente requer um conhecimento metacognitivo específico, geralmente incomum aos não membros da comunidade discursiva acadêmica. Assim, sujeitos candidatos a inserirem-se nessa comunidade encontram-se em processo de desenvolvimento de escrita, porém, não qualquer escrita, mas sim uma escrita particular, atestadora da filiação à ordem do discurso acadêmico científico, materializada em gêneros típicos do texto especializado.

\section{Desenvolvimento de escrita:}

a aquisição de conhecimentos

Embora a noção de desenvolvimento de escrita costume se ligar à aquisição do código por sujeitos em fase inicial de escolarização (Ferreira, 2014), entendemos, conforme Klemp (2004), que o letramento acadêmico é um processo no qual há desenvolvimento contínuo quanto aos conhecimentos que orientam a interação mediada pelos textos especializados desse domínio. Portanto, ser academicamente letrado atesta a condição daquele que adquiriu estratégias eficazes para compreender e usar as linguagens demandadas pelos textos especializados que circulam na academia.

Coadunando-se a essa ideia, Ferreira (2014), ao tomar por base Beaufort (1998 apud Swales, 2009) e Tardy (2009), propõe-nos cinco conhecimentos para a produção do texto especializado em domínio acadêmico: os conhecimentos do gênero, da norma linguística padrão, do processo de escrita, do assunto e, por fim, da comunidade discursiva acadêmica, que engloba todos os conhecimentos anteriores.

Desse modo, o sujeito graduando encontra-se em processo de desenvolvimento de escrita em um domínio no qual é recém-ingresso, condição que lhe exige a incorporação de conhecimentos que o filiem a uma determinada ordem do discurso, a ordem do discurso acadêmico científico, marcada pelo alto grau de convencionalidade. 
0 aprendizado no que diz respeito a regras e normatizações, segundo Coracini (2010), faz parte dos usos orientados da linguagem, pois produzir textos depreende o alinhamento à determinada ordem do discurso: "aprender a respeitar convenções, tacitamente acordadas pelos membros de diferentes formações discursivas ou de diferentes grupos sociais". Isto é, "para entrar no jogo é preciso conhecer suas regras" (Coracini, 2010, p.21).

\section{Escrevendo na e para a academia:} o gênero relato de experiência

0 relato de experiência é um gênero estabelecido do domínio acadêmico que tem como objetivo público apresentar uma experiência didática e/ou metodológica desenvolvida consoante o auxílio de parâmetros teóricos. Nesse tipo de texto, temos a presença de um produtor que relata sua experiência como narrador-personagem (Ferreira, 2014). No entanto, dado o conjunto de convenções estabelecidas em se tratando de gêneros do domínio acadêmico-científico, a existência de um narrador-personagem não significa, necessariamente, nível irrestrito de pessoalidade já que o conhecimento partilhado pelos membros da comunidade discursiva acadêmica inclui a construção impessoal do texto (Bazerman, 1988).

Ainda conforme Bazerman, ao se observar a retórica da ciência, percebe-se que certas ferramentas e truques - e a estratégia da construção impessoal do texto, sem dúvidas, aí pode ser enquadrada - revelaram-se tão úteis que tornaram-se regularizados e até mesmo elementos obrigatórios institucionalizados de tipos particulares de comunicação científica (Bazerman, 2006, p.60).

No que tange à regularização formal, podemos descrever o gênero relato de experiência conforme modelo elaborado por Silva (2002), no qual a organização retórica do gênero pode ser esquematizada, conforme o Quadro 1. 
Quadro 1 - A organização retórica do relato de experiência didática.

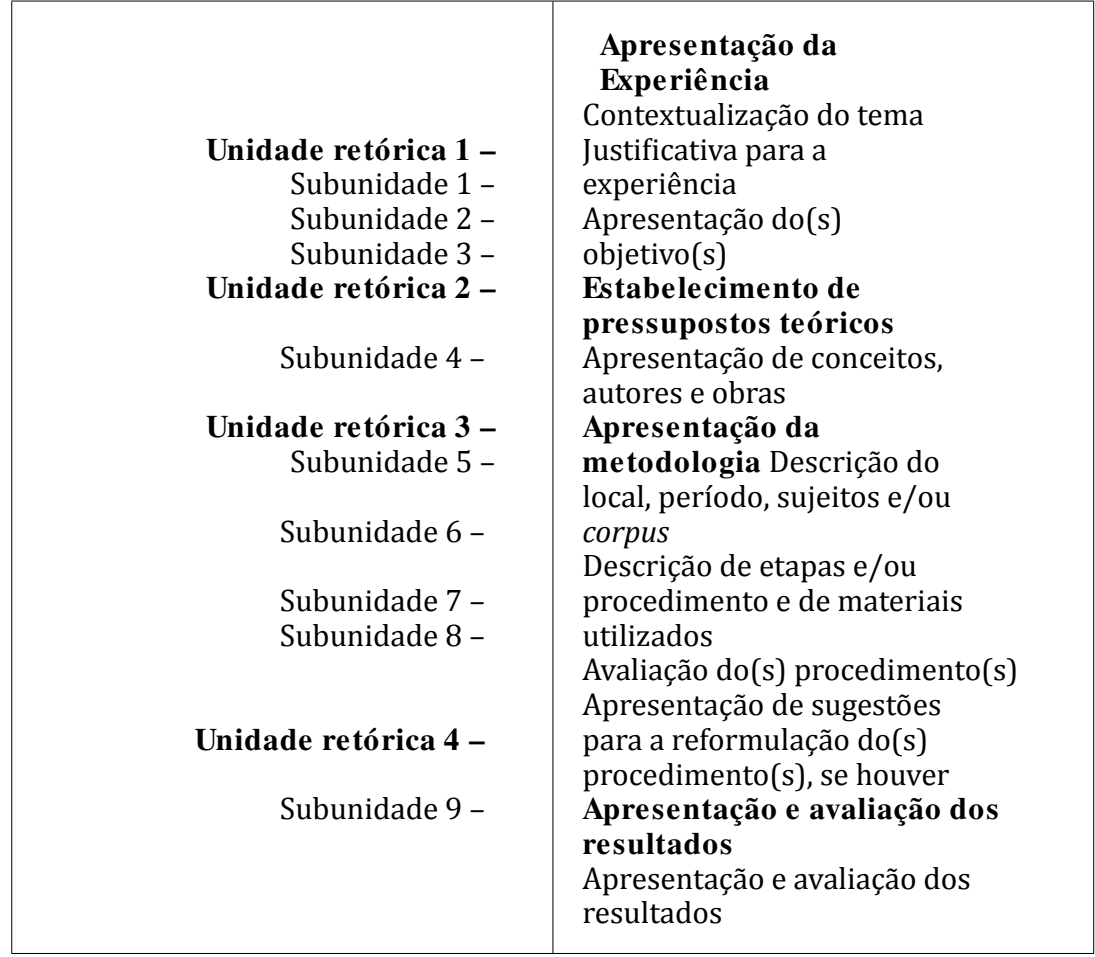

Fonte: Silva (2002, p.31).

Como podemos observar, algumas unidades retóricas costumam identificar o gênero relato de experiência, a saber: a unidade de apresentação, de fundamentação teórica, de apresentação dos fatos e, por fim, a de avaliação desses fatos. Conforme indicado em nossa introdução, este trabalho elegeu a Unidade 1 - Apresentação da experiência para empreender a análise da escrita produzida pelos sujeitos graduandos investigados.

\section{Unidade 1 - Apresentação da experiência (Introdução)}

Esta unidade retórica coaduna-se à seção de introdução e costuma apresentar informações que contextualizem acerca do tema enfocado pela experiência didática e/ou metodológica realizada, bem como aspectos referentes ao contexto geral de realização da experiência. Nesse sentido, analisaremos, inicialmente, a Produção 1, tendo em vista indicarmos a realização dessa unidade retórica e suas subunidades. 
A introdução da Produção 1, conforme veremos adiante, apresenta as três subunidades previstas por Silva (2002): subunidade 1 contextualização do tema, subunidade 2 - justificativa para a experiência e subunidade 3 - apresentação dos objetivos. Vejamo-la a seguir:

\section{Produção 1 - sujeito 1}

O ensino do seminário em aulas de língua inglesa por meio de estratégias de conversação: uma proposta de sequência didática

\section{Introdução}

Uma das atividades mais utilizadas em salas de aula, tanto em disciplinas de língua materna quanto de língua estrangeira (LE), no ensino básico e no ensino superior, é o seminário. No que diz respeito ao ensino de inglês - língua estrangeira (ILE), o seminário é uma atividade constantemente usada para se explicitar algum conteúdo específico da disciplina que relacione a língua materna com o assunto estudado, sem que haja uma contextualização da importância de seu uso, de como ele se constitui e de como pode se articular com o uso de ILE. Além disso, em certos casos, os seminários são usualmente apresentados em língua portuguesa, sem a preocupação por parte dos professores de apresentar aos seus alunos estratégias para que eles se apresentem utilizando a língua inglesa.

Assim, nos parece que o estudo, o ensino e, principalmente, o uso desse gênero se apresenta fragmentado em nossa educação, de forma que muitos professores já se acomodaram e se acostumaram a pensar que o seu ensino não diz respeito a esta disciplina, cabendo apenas aos professores de língua portuguesa ensiná-lo. E apesar de muitos já compreenderem que o ensino de ILE não pode mais ser visto de maneira estanque e formal, não conseguem (ou não querem) inserir tais atividades em seus projetos pedagógicos, mesmo sendo este um gênero de importante uso na vida de qualquer indivíduo, dentro e fora da escola.

Essas são apenas algumas das reflexões proporcionadas pelo estudo da disciplina Estudos de Oralidade e Escrita do curso de Letras da Universidade Federal de Campina Grande (UFCG), 2014, em que o seminário, dentro de seus condicionantes e suas principais características, foi levado em consideração ao se estudar gêneros articuladores do oral e da escrita. Neste estudo, que incluiu a produção e apresentação de um trabalho em torno do seminário, desenvolvemos algumas atividades relacionadas a uma sequência didática como proposta de ensino para este gênero, relacionando também outros já estudados, como o debate e a entrevista.

Logo, neste relato, pretendemos apresentar como se deu a elaboração e apresentação desse trabalho para a turma da referida disciplina, atentando especificamente para a proposta de ensino deste gênero em aulas de Inglês - língua estrangeira, explicitando a importância de seu ensino e do uso de estratégias de conversação. Tais estratégias, basicamente, dizem respeito a uma determinada prática no estudo de língua, que foram transformadas e utilizadas como estratégias de apresentação, como colaboradoras para a execução de um seminário. 
A depreensão da organização retórica construída pelo Sujeito 1 nos permite perceber o uso de diferentes estratégias, tendo em vista a tentativa de adequar-se às convenções discursivas atestadoras da condição de pertencimento à comunidade discursiva acadêmica. 0 trecho que segue indica o movimento inicial desse sujeito em sua introdução, o de apresentar a contextualização acerca do tema abordado, neste caso, o uso do gênero oral seminário em sala de aulas de Língua Inglesa.

Subunidade 1, Contextualização do tema:

A escolha pelo uso dessas estratégias se justifica pelo fato delas propiciarem uma maior contextualização daquilo que se está estudando em inglês - língua estrangeira e também a intertextualidade existente ao se relacionar as atividades de conversação, características do ensino de língua estrangeira, e o uso do seminário e/ ou de exposições orais, tanto em ILE, quanto em língua materna.

Dessa forma, organizamos este relato em: introdução, que é a presente parte; em seguida, apresentamos e explicamos os nossos procedimentos metodológicos; depois, descrevemos a apresentação da proposta de sequência didática em sala de aula à turma; e, por último, fazemos algumas reflexões acerca dessa experiência e suposições quanto à funcionalidade de nossa proposta.

Conforme podemos constatar, o Sujeito 1 realiza a subunidade 1 introduzindo um tema: o uso do seminário em sala de aula. Um ponto a se destacar nessa subunidade é a compreensão que o produtor demonstra ter acerca da necessidade de convencer o leitor quanto à relevância de seu trabalho. Percebemos isso quando ele coloca o gênero seminário como uma das atividades mais utilizadas em salas de aula e quando aponta aspectos merecedores de atenção quanto ao uso desse gênero, evidenciando a conveniência de se discutir tal uso em contexto de ensino-aprendizagem.

Tal fato, indica-nos que o Sujeito 1 já incorporou conhecimentos quanto à comunidade discursiva acadêmica, na qual procura se inserir enquanto graduando produtor, pois, conforme nos esclarece Coracini (1991), o discurso científico, típico dessa comunidade, intenciona o convencimento acerca da validade e do rigor daquilo que apresenta. No caso em análise, no qual figura um relato de experiência, justifica-se um discurso preponderantemente voltado para a validação dos apontamentos propostos, desdobrando-se no encadeamento de justificativas quanto à pertinência do tema e da problemática enfocada, o que demanda o uso de estratégias de persuasão, notadamente por meio do uso de marcas linguísticas que funcionam como operadores argumentativos (Koch, 2003). 
Constatamos a orientação argumentativa do texto pelo uso do intensificador mais em "uma das atividades mais utilizadas em sala de aula", e pelo uso do operador além disso, segundo grifo ${ }^{1}$ do excerto, que acrescenta informação ratificadora de uma mesma conclusão, a de que apesar do uso recorrente do seminário, tal uso ainda carece de reflexões. Nesse sentido, o Sujeito 1 demonstra não apenas conhecer a orientação persuasiva que costuma marcar os textos que circulam na esfera acadêmico-científica, mas também ser eficiente ao aplicar tal conhecimento à feitura de seu próprio texto.

No que tange à subunidade 2, essa se dá pela apresentação de justificativas para realização da experiência, que enfoca o ensino do gênero seminário.

Subunidade 2, Justificativa para a experiência:

Assim, nos parece que o estudo, o ensino e, principalmente, o uso desse gênero se apresenta fragmentado em nossa educação, de forma que muitos professores já se acomodaram e se acostumaram a pensar que o seu ensino não respeito a esta disciplina (inglês, LE), cabendo apenas aos professores de língua portuguesa ensiná- lo. (...) A escolha pelo uso dessas estratégias (estratégias de conversação) se justifica pelo fato delas propiciarem uma maior contextualização daquilo que se está estudando em inglês (...)

No fragmento anterior, referente à subunidade 2, justificativa para a experiência, o Sujeito 1 justifica a necessidade de se discutir a forma como o seminário tem sido concebido em aulas de língua inglesa - LE, pois, conforme ele, "parece que o estudo, o ensino e, principalmente, o uso desse gênero se apresenta fragmentado em nossa educação".

Observemos que ele inicia o parágrafo por meio de um operador cuja função é estabelecer a ideia de arremate em relação aos fatos expostos anteriormente: assim. Tais marcas linguísticas, também encontradas na subunidade 1 , indicam a atenção do produtor quanto à sequencialização lógica do texto, demonstrando seu nível de consciência linguística e textual, ainda que apresente desvios da norma linguística padrão, conforme se atesta pela não concordância do verbo apresenta, primeira linha, com o sujeito composto a que se refere.

Destaca-se também o processo de pessoalização, atestado pelo uso das formas da $1^{\mathfrak{a}}$ pessoa do plural - nos, nossa. Conforme Benveniste

\footnotetext{
${ }^{1}$ São nossos os grifos nos excertos analisados.
} 
Escrevendo na e para academia: um estudo sobre a incorporação do discurso...

(1966), a pessoalização diz respeito à explicitação do enunciador na superfície do discurso. A opção pela $1^{\underline{a}}$ pessoa do plural sinaliza um modo de preservação de face, à medida que pluraliza a responsabilidade pelo dito, mas também uma forma de envolvimento com o leitor, que passa a ser chamado a identificar-se com esse dito. Ainda nesse sentido, destacase o uso da estratégia de modalização, importante característica da escrita acadêmica, como se nota pelo uso que o produtor faz do modalizador parece, terceiro grifo do trecho, destinado a atenuar a responsabilidade do produtor quanto à afirmação que promove, orientando o leitor para como o discurso deve ser lido.

No que tange à construção da subunidade 3 , Apresentação do(s) objetivo(s), essa aparece a partir da exposição do objetivo do relato de experiência, por meio do qual subentende-se, consequentemente, o objetivo de realização da própria experiência:

Logo, neste relato, pretendemos apresentar como se deu a elaboração e apresentação desse trabalho (em torno do gênero seminário) para a turma, atentando especificamente para a proposta de ensino deste gênero em aulas de inglês (...)

Nesse trecho, podemos identificar a subunidade 3 por meio dos marcadores metadiscursivos ${ }^{2}$ pretendemos apresentar, que sinalizam o conteúdo informacional referente ao objetivo do trabalho. Na construção dessa subunidade, percebemos um produtor ainda em fase de desenvolvimento de escrita acadêmica, fato que se nota pelo uso do operador logo, introdutor da subunidade, o qual, mesmo carregando uma orientação argumentativa para conteúdo informacional referente à conclusão, é usado para introduzir os objetivos do trabalho. Tal fato indicia que esse produtor, embora ciente da função de conectar informações dos operadores, ainda apresenta fragilidades quanto ao conhecimento de seus conteúdos semânticos.

O Sujeito 1 ainda constrói uma subunidade não prevista pelo modelo de Silva (2002), o referente à organização interna do trabalho:

\footnotetext{
2 Marcadores metadiscusivos podem ser entendidos, consoante Motta-Roth; Hendges (2010), como pistas lexicais que caracterizam as informações presentes em diferentes segmentos do texto. Tais pistas são importantes mecanismos de identificação de diferentes movimentos do texto pelo leitor.
} 
Dessa forma organizamos este relato em: introdução, que é a presente parte; em seguida, apresentamos e explicamos os nossos procedimentos metodológicos; depois, descrevemos a apresentação da proposta de sequência didática em sala de aula à turma; e por último, fazemos algumas reflexões acerca dessa experiência e suposições à funcionalidade de nossa proposta.

Conforme se atesta pelo uso do operador dessa forma, o Sujeito 1 procura promover amarrações lógico-semânticas entre os conteúdos informacionais anteriores a essa subunidade, demonstrando a necessidade de fazer uso de operadores como modo de estabelecer relações. Embora se possa questionar o uso desse operador no contexto analisado, já que introduz o parágrafo final da unidade retórica de introdução, cujo conteúdo informacional, conforme visto, não dialoga diretamente com o conteúdo informacional exposto anteriormente, percebe-se que o produtor, mesmo desconhecendo alguns aspectos da natureza semântica dessas amarrações, está ciente de seu papel na promoção de conexões.

Destaca-se também a escolha do termo suposições, segundo grifo do trecho, utilizado para orientar o leitor quanto ao que será visto mais diante, quando a experiência realizada será analisada. Nesse sentido, a adoção do termo fragiliza o teor persuasivo típico da escrita que materializa gêneros do domínio acadêmico-científico que, conforme vimos, orienta-se pelo estabelecimento do rigor e validade de suas asserções, não coadunandose com a proposição de suposições.

Finalmente, vale salientar a construção dessa última subunidade da introdução como uma evidência do contato desse produtor com outros gêneros desse domínio, como o artigo científico, já que nesse gênero é bastante recorrente a construção dessa subunidade. Assim, provavelmente influenciado pelo contato com artigos científicos, o Produtor 1 promove a antecipação da organização informacional do trabalho para o leitor. Essa preocupação com a orientação do leitor demonstra um produtor ciente do processo de escrita como um fenômeno social de interação verbal, no qual o produtor deseja passar uma imagem de si à medida que se orienta pela imagem de seu leitor.

Com base no exposto, depreendemos algumas estratégias utilizadas pelo Sujeito 1 como meio de engajar-se nas práticas letradas da comunidade discursiva acadêmica, a saber: a) Construção da unidade retórica de apresentação em consonância com o que é altamente esperado para o gênero relato, conforme se atesta pela realização 
das três subunidades apontadas por Silva (2002). Tal fato indicia um produtor familiarizado com a estrutura retórica do gênero, o que, em consonância com Ferreira (2014), estamos tomando como pertencente à ordem do conhecimento do gênero; b) Opção por um texto orientado pelo caráter argumentativo, marcado pela recorrência de sequências que justificam a pertinência do trabalho, além do uso de operadores argumentativos, o que evidencia o conhecimento do produtor quanto ao discurso acadêmico científico, caracterizado pelo fazer persuasivo (cf. Coracini, 1991); c) Tentativa de estabelecimento de relações lógico-semânticas entre as partes do texto. Neste caso, percebemos um produtor ciente da necessidade de garantir a progressão do texto por meio do uso de diferentes marcas linguísticas, entre as quais, operadores argumentativos, demonstrando ciência quanto ao processo de textualização; d) Adoção das formas de 1므 pessoa do plural (sujeito universal) como modo de garantir a preservação de face, além da anuência do leitor, estratégia que também revela conhecimento quanto à comunidade discursiva acadêmica, a qual oferece restrições quanto ao nível de pessoalidade utilizado para construção do texto; e) Construção de subunidade destinada à orientação do leitor quanto à organização informacional do trabalho, o que demonstra a construção do texto pautada pela referência à determinada audiência, evidenciando conhecimentos que passam pelo processo de textualização, pelo conhecimento do gênero e pelo conhecimento da comunidade discursiva acadêmica; f) 0 uso da estratégia de modalização, importante característica da escrita em domínio acadêmico, atestando, mais uma vez, conhecimento relativo a essa comunidade discursiva.

Vejamos, agora, como a Sujeito 2 constrói a unidade retórica 1 Apresentação da experiência, que, conforme vimos anteriormente, coaduna-se à seção destinada à introdução do trabalho: 
Produção 2 - sujeito 2 entrevista

Oralidade e Escrita: análise a respeito do trabalho com o gênero

Entendemos que a língua falada e a língua escrita são dois aspectos intimamente ligados ao homem e que entre a duas modalidades, há mais afinidade do que altercação. Essas formas de linguagens de discursos têm especificidades características, é um fato que não se pode denegar, mas é da mesma forma evidente entre elas muito em comum. Boa parte dos estudos que se refere à oralidade oral e à escrita foi feito com base em textos de conversacionais (da fala) em a checagem com textos em prosaico (da escrita). Não resta dúvida alguma que um determinado texto do colóquio espontâneo, como por exemplo: uma conversa entre amigos apresenta peculiaridades da língua falada. A mesma pode certamente representar a linguagem oral, da mesma forma um texto em prosaico, como um artigo acadêmico, apresenta características da escrita e representa, pode ser um exemplo de linguagem escrita.

Temos como objetivo principal abordar o gênero entrevista em sala de aula; assim como desenvolver nos alunos a capacidade de identificação das diferenças entre a entrevista oral e escrita; promover a transcrição de entrevistas orais e estimular o respeito entre os alunos, especialmente no que se refere ao bullying.

Conforme podemos atestar pelo excerto anterior, a introdução do relato é relativamente curta, apenas dois parágrafos, apresentando duas das subunidades apontadas por Silva (2002), a subunidade 1 Contextualização do tema e a subunidade 3 - Apresentação dos objetivos.

No entanto, antes de partirmos para a análise dessas subunidades, consideramos a pertinência de tomar a elaboração do título do trabalho como elemento atestador do nível de desenvolvimento de escrita acadêmica apresentada pelo Sujeito 2. Nesse sentido, um ponto que se destaca é o desvio da norma padrão no que tange ao uso inadequado da crase. Tal realidade indicia um produtor com um domínio ainda frágil da norma padrão da língua. Segundo Ferreira (2014), o domínio da norma linguística padrão representa uma exigência da escrita acadêmica, de modo que seu não domínio pode significar a não inserção na comunidade.

No que tange ao primeiro movimento promovido, nós o encontramos organizado em um único parágrafo, tratando-se da subunidade 1 Contextualização do tema.

Entendemos que as línguas falada e a língua escrita são dois aspectos intimamente ligados ao homem e que entre $\underline{a}$ essas duas modalidades, há mais afinidade do que altercação. Essas formas de linguagens de discursos têm 
Escrevendo na e para academia: um estudo sobre a incorporação do discurso...

especificidades características, é um fato que não se pode denegar, mas é da mesma forma evidente entre elas_muito em comum. Boa parte dos estudos que se refere à oralidade oral e a escrita foi feita com base em textos de conversacionais (da fala) em e checagem com textos em prosaico (da escrita). Não resta dúvida alguma que um determinado texto do colóquio espontâneo, como por exemplo: Uma conversa entre amigos apresenta peculiaridades da língua falada. A mesma pode certamente representar a linguagem oral, da mesma forma um texto em prosaico, como um artigo acadêmico, apresenta características da escrita e representa, exemplo de línguagem (sic) escrita.

No caso em análise, chama a atenção o fato de encontrarmos um texto confuso, prolixo, com presença de incoerências, pleonasmo, lacunas, desvios da norma linguística padrão, conforme se evidencia pelos grifos no excerto anterior. Além disso, o relato se volta para o trabalho com o gênero entrevista, no entanto, curiosamente, não encontramos nenhuma referência ao gênero nessa subunidade, pois o conteúdo informacional se volta para aspectos relativos à oralidade e à escrita, como estratégia de contextualização.

Isso não seria problemático caso o produtor, após esse conteúdo mais genérico, encaminhasse o texto para um conteúdo mais específico, ligado ao gênero entrevista, tema de seu trabalho, entretanto, não é o que acontece, ocorrendo uma quebra abrupta entre o conteúdo desse parágrafo e a subunidade 3 - Apresentação dos objetivos, construída em seguida.

Tal ruptura nos levou a suspeitar que o Sujeito 2 tivesse se utilizado da estratégia de preenchimento (Ferreira, 2014), isto é, tivesse se utilizado do plágio como modo de construir seu texto. A partir disso, realizamos uma busca na internet e, conforme suspeita, encontramos um artigo, publicado em revista da área de língua portuguesa, linguística e literatura ${ }^{3}$, do qual todo o primeiro parágrafo da introdução da Produção 2, excerto anterior, foi integralmente retirado, sem qualquer alteração.

Para Ferreira (2014), o plágio demonstra desconhecimento quanto à comunidade discursiva acadêmica, já que nela essa prática é tomada como antiética. Desse modo, fazer uso do plágio é contrariar as regras que, no interior dessa comunidade, regem o direito à autoria.

\footnotetext{
${ }^{3} \mathrm{O}$ artigo plagiado está publicado na Revista Letra Magna, Revista Eletrônica de Divulgação Científica em Língua Portuguesa, Linguística e Literatura - Ano 4 n.7 - 2o Semestre de 2007. Disponível em: <http://www.letramagna.com/ continuumtipologico.pdf>. Acesso em 10 out. 2014.
} 
Assim, o uso do plágio como estratégia de preenchimento parece demonstrar um produtor ainda desconhecedor da comunidade discursiva acadêmica, mas também indica fragilidade no que tange ao domínio do conhecimento do processo de escrita, já que, além de plagiar, o produtor não procura estabelecer relações entre o fragmento plagiado e seu próprio texto, nem tão pouco parece perceber os vários problemas do texto plagiado, isentando-se de promover nele quaisquer alterações, não se sabe se por não ter tido condições de perceber os problemas ou por falta de atenção.

Percebe-se, desse modo, que o fato de o Sujeito 2 ocupar o lugar social de graduando não o coloca, necessariamente, no lugar discursivo de membro da comunidade acadêmica, já que para isso é preciso mobilizar determinados conhecimentos, de modo a atender a convenções partilhadas pelos membros dessa comunidade.

Uma provável hipótese para explicar o comportamento do Produtor 2 é seu curto contato com as práticas que marcam essa comunidade, tendo em vista estar ele ainda em seu segundo período no curso de Letras. Ademais, depreendemos também que esse sujeito, possivelmente, encontra-se ainda muito influenciado pelas práticas de escrita que marcam o domínio escolar, no qual, por vezes, há tolerância com a atividade do tipo "Ctrl c Ctrl v".

Passemos, a partir de agora, a discutir a subunidade 3 Apresentação do(s) objetivo(s), última subunidade constitutiva da introdução da Produção 2:

Temos como objetivo principal abordar o gênero entrevista em sala de aula assim como desenvolver nos alunos a capacidade de identificação das diferenças entre a entrevista oral e escrita promover a transcrição de entrevistas orais e estimular o respeito entre os alunos, especialmente no que se refere ao Bullying.

Conforme pode-se perceber no excerto, o Sujeito 2 apresenta os objetivos de sua experiência, demonstrando, ainda que de forma incipiente, conhecimento acerca do gênero. Tal fato se atesta pelo uso de marcadores metadiscursivos - objetivo, abordar, desenvolver, promover, estimular. 0 produtor adota ainda o uso da $1^{\text {a }}$ pessoa do plural, o que demonstra alguma ciência quanto às convenções que marcam o processo 
Escrevendo na e para academia: um estudo sobre a incorporação do discurso...

de pessoalização em textos acadêmicos. No entanto, o uso dessas estratégias não é condição suficiente para garantir a unidade temática da unidade retórica de Apresentação da experiência - Introdução, de modo que o texto apresenta-se comprometido, fundamentalmente, tanto pelo desconhecimento acerca da comunidade discursiva acadêmica quanto no que tange o processo de escrita.

\section{Conclusões}

A análise das unidades retóricas de Apresentação da experiência dos relatos produzidos demonstrou a utilização de diferentes estratégias para produção do texto especializado em domínio acadêmico por graduandos do curso de Letras, indiciando, assim, produtores que se enquadram em diferentes níveis de desenvolvimento de escrita acadêmica.

O Sujeito 1 fez uso de estratégias que atestam pelo menos três conhecimentos: aqueles relacionados ao gênero, pois produziu todas as subunidades previstas por Silva (2002); conhecimentos quanto ao processo de escrita, atestados pela utilização de conectivos, marcadores metadiscursivos, argumentativos; e conhecimentos relativos à comunidade discursiva acadêmica, que se atestam pelo uso da $1^{1}$ a pessoa do plural, pela tentativa de modalizar o texto, além da produção de uma escrita de caráter persuasivo. Já o Sujeito 2 demonstrou certo conhecimento do gênero, já que considerou pertinente a presença de duas das subunidades previstas por Silva (2002), no entanto, ao se utilizar da estratégia de preenchimento, por meio do plágio, esse produtor demonstra fragilidades no que tange ao processo de escrita e, principalmente, desconhecimento no que tange à comunidade discursiva acadêmica, a qual tem no plágio a violação à convenção do direito à autoria.

A partir disso, depreende-se que os sujeitos 1 e 2 encontram-se em diferentes níveis de desenvolvimento de escrita acadêmica, bem como de assunção à ordem do discurso acadêmico-científico. 0 Sujeito 1 encontra-se em nível mais avançado de desenvolvimento de escrita acadêmica quando comparado ao Sujeito 2, embora ambos pertençam ao mesmo semestre do curso. Isso porque o Sujeito 1 atende de modo mais eficiente ao conjunto de convenções que marcam a escrita em domínio acadêmico, demonstrando a ativação de conhecimentos necessários para produção do texto especializado. Tal realidade acaba por ratificar que, para além de 
conhecimentos formais, a escrita acadêmica requer que, em seu desenvolvimento, o produtor assuma o lugar discursivo de membro afinado às convenções que marcam a ordem do discurso acadêmico científico.

Para tanto, acreditamos ser necessário que um olhar mais detido seja oferecido para o processo de desenvolvimento de escrita acadêmica, principalmente por meio do reconhecimento de que cabe ao espaço acadêmico a responsabilidade de promover o ensino necessário à inserção de novos membros na comunidade discursiva acadêmica. Isso significa que é na universidade que o aluno aprende a falar e a escrever na\para a universidade. Portanto, torna-se essencial que conhecimentos necessários à produção do texto especializado, tácitos a membros experientes, possam ser mais claramente delineados e discutidos nas salas de aula de nível superior, de modo a instrumentalizar-se o aluno para o reconhecimento de marcas (linguísticas, textuais, discursivas) de inserção na comunidade acadêmica.

\section{Referências}

BARTON, D. Literacy: an Introduction to the ecology of written language. London: Blackwell, 1994.

BARTON, D.; HAMILTON, M. Literacy practices. In: BARTON, D; HAMILTON, M \& IVANIC, R. (Org.). Situated literacies: reading and writing in context. New York: Routledge, p.7-15, 2000.

BAZERMAN, C. Shaping written knowledge. Madison: The University of Wisconsin Press, 1988.

BAZERMAN, C. Gênero, agência e escrita. HOFFNAGEL, J. C; DIONISIO, A. P. (Org.). Tradução e adaptação Judith Chambliss Hoffnagel. São Paulo: Cortez, 2006.

BENVENISTE, É. Problèmes de linguistique générale I. Paris: Gallimard, 1966.

BHATIA, V. K. A análise de gêneros hoje. In: BEZERRA, B. G.; BIASE-RODRIGUES, B; CAVALCANTE, M. M. (Org.). Gêneros e sequências textuais. Recife, PE: Edupe, 2009.

CORACINI. M. J. R. F. Um fazer persuasivo: o discurso subjetivo da ciência. Campinas, SP: Pontes, 1991.

CORACINI, M. J. R. F. Discurso e escrit(ur)a de si: entre a necessidade e a (im)possibilidade de ensinar. In.: ECKERT-HOFF, B.; CORACINI, M. J. R. F. (Org.). Escrit(ur) a de si e alteridade no espaço papel-tela: alfabetização, formação de professores, línguas materna e estrangeira. Campinas, SP: Mercado das letras, 2010.

FERREIRA, Elisa Cristina Amorim. Desenvolvimento da escrita na academia: investigação longitudinal do percurso de licenciandos em Letras. Dissertação de mestrado. Universidade Federal de Campina Grande, 2014. Campina Grande - PB, 198f. 
Escrevendo na e para academia: um estudo sobre a incorporação do discurso...

FISCHER, A. Letramento acadêmico: uma perspectiva portuguesa. Revista Acta Scientiarum Language and Culture. Maringá. jul./dez., v.30, n.2, p.177-187, 2008.

GEE, J. P. Social linguistics and literacies: ideology in Discourses. 2ed. London/ Philadelphia: The Farmer Press, 1996.

GEE, J. P. Reading as situated language: a sociocognitive perspective. In: Journal of Adolescent \& Adult Literacy. Newark, v.8, n.44, p.714-725, 2001.

KLEMP, R. Academic literacy: making students content learners, 2004. Disponível em <http:www.greatsource.com \rehand $\backslash 6$-8\pdfs $\backslash$ Academic_Literacy.pdf>.

KOCH, I. G. V. A inter-relação pela linguagem. São Paulo: Contexto, 2003.

MILLER, Carolyn R. Genre as social action. Quarterly Journal of Speech, n.70, p.151167, 1984.

MOTTA-ROTH, D.; HENDGES, G. R. Produção textual na universidade. São Paulo: Parábola, 2010.

STREET, B. Literacy in theory and practice. Cambridge: CUP, 1984.

STREET, B. Os novos estudos sobre o letramento: histórico e perspectivas. In: MARINHO. M.; CARVALHO, G. T. (Org.). Cultura escrita e letramento. Belo Horizonte: Editora UFMG, 2010.

SILVA, Jocília Rodrigues. Relato de Experiência Didática: elementos para a descrição e ensino do gênero. 90f. Dissertação de Mestrado (Mestrado em Linguística). Universidade Federal da Paraíba - UFPB. João Pessoa, Paraíba. 2002.

SWALES, J. M. Sobre modelos de análise do discurso. In: BIASI-RODRIGUES, B.; ARAÚJO, J. G.; SOUSA, S. C. T.(Orgs.). Gêneros textuais e comunidades discursivas: um diálogo com John Swales. Belo Horizonte: Autêntica Editora, 2009.

SWALES, J. M. Genre analysis: English in academic and research settings. Cambridge: Cambridge University Press, 1990.

TARDY, C. Building genre knowledge. West Lafayette: Parlor Press, 2009. 
Sobre o livro

Formato $\quad 16 \mathrm{~cm} \times 23 \mathrm{~cm}$

Tipologia Cambria

Papel Sulfite $75 \mathrm{~g}$

\section{gráficaufu}


Não é possível no espaço discursivo acadêmico-universitário dizer qualquer coisa de qualquer modo. Esse confronto provoca uma outra relação com o saber e com a sua produção. É notório que o conhecimento produzido nos círculos acadêmico-universitários se caracteriza, basicamente, por se afastar, radicalmente, daquele produzido no espaço do senso comum, mesmo quando 0 aluno universitário faz dele o seu ponto de partida. Então, a tarefa que se apresenta a um aluno universitário em seu processo de entrada nessa ordem discursiva que lhe impõe outros modos de dizer comporta uma via de mão dupla: por um lado, para que se constitua nesses novos modos de dizer, ele, necessariamente, precisa se submeter às leis que compõem as regras de construção discursiva de tais modos; por outro lado, precisa encontrar uma maneira de subverter essas regras de tal forma que a elas não sucumba. 